
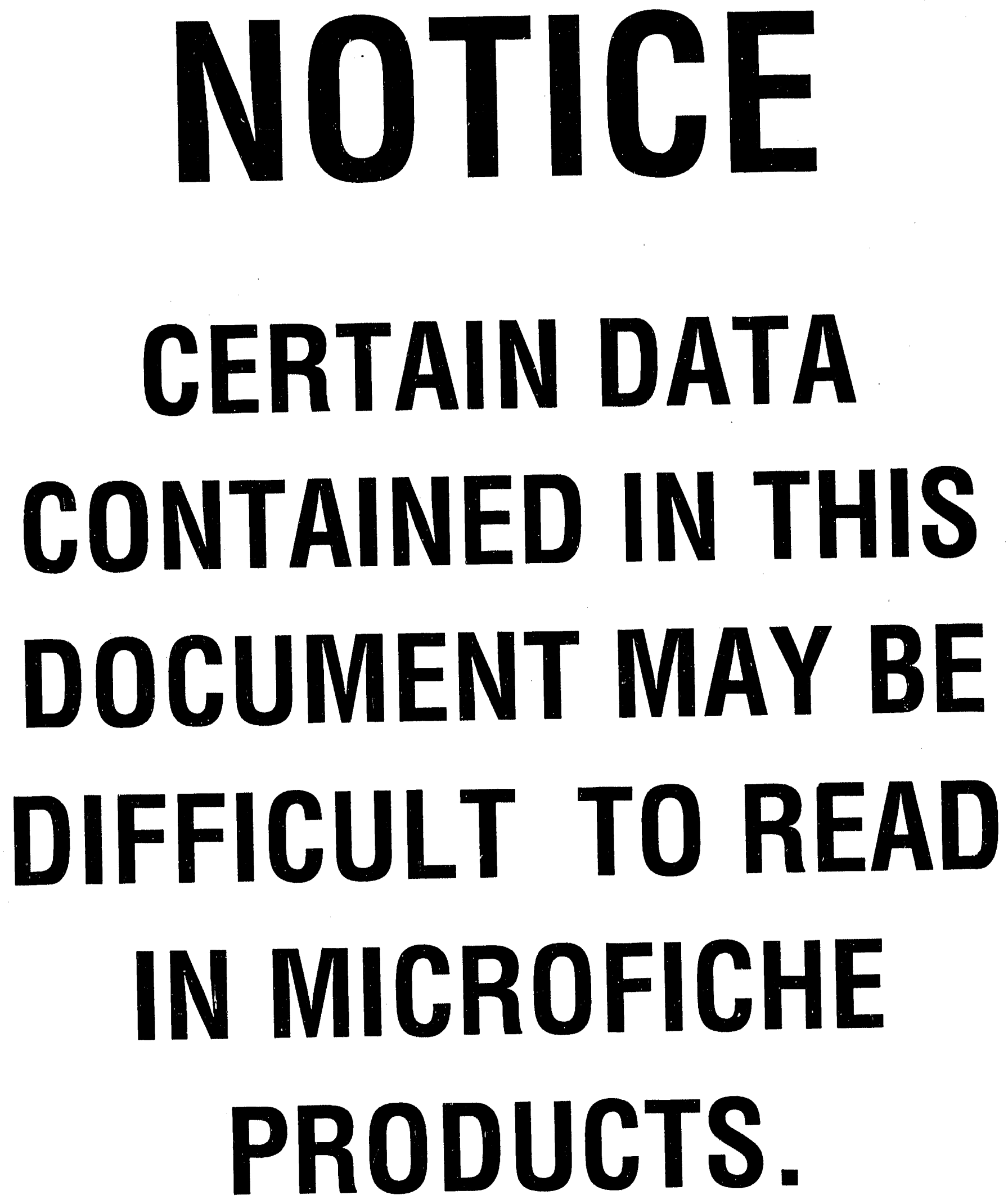


\section{Endothermic Photo-Catalytic Reactions}

NREL/TP-253-4277

Final Report

DE91 002142

H.W. Prengle, Jr., W.E. Wentworth, K.C.

Polonczyk, M. Saghafi, J.A. Wilking, and K.S. Kramer

University of Houston

houston, Texas

NREL Technical Monitor: R. Gerald Nix

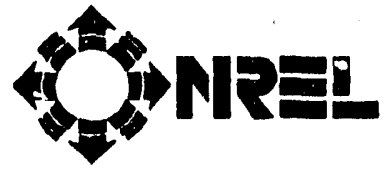

National Renewable Energy Laboratory

(formerly the Solar Energy Research Institute)

1617 Cole Boulevard

Golden, Colorado 80401-3393

A Division of Midwest Research Institute

Operated for the U.S. Department of Energy

urder Contract No. DE-AC02-83CH10093

Prepared under Subcontract Nos. XX-7-07028-1

and XX-6-06006-1

April 1992 
This report describes subcontracted research. The report is unreviewed and expresses only the opinions of the author[s]. It has been prepared for reproduction from the best available copy.

\title{
NOTICE
}

This report was prepared as an account of work sponsored by an agency of the United States government. Neither the United States government nor any agency thereof, nor any of their employees, makes any warranty, express or implied, or assumes any legal liability or responsibility for the accuracy, com- 1 pleteness, or usefulriess of any information, apparatus, product, or process disclosed, or represents that its use would not infringe privately owned rights. Reference herein to aliy specific commercial product, process, or service by trade name, trademark, manufacturer, or otherwise does not necessarily constitute or imply its endorsement. recommendation, or favoring by the United States government or any agency thereot. The views and opinions of authors expressed herein do not necessarily state or reflect those of the United States government or any agency thereot.

\author{
Printed in the United Staias of America \\ Available from: \\ National Technical Information Service \\ U.S. Department of Commerce \\ 5285 Port Royal Road \\ Springfield, VA 22161 \\ Price: Microfiche A01 \\ Printed Copy A05
}

Codes are used for pricing all publications. The code is cetermined by the number of pages in the publication. Information pertaining to the pricing codes can be found in the current issue of the following publications which are generally available in most libraries: Energy Research Abstracts (ERA); Govern. ment Reports Announcements and Index (G.9A and I); Scientific and Technical Abstract Reports (STAR); and publication NTIS-PR-360 available from NTIS at the above address. 


\section{- EXECUTIVE SUMMARY .}

The overall objective of this report is to present the results of an investigation to provide guidelines for future experimental work, on solar energy driven endothermic photo-catalytic reactions, and primarily to select candidate synthesis reactions which lead to high \$-value products. Since the initial report a group of exothermic aromatic and olefin oxidation reactions have been included also, as possible night-time reactions.

An intensive literature search was conducted to find properties, market demand, and prices of pertinent chemicals; meeting four criteria: 1) -the reaction must be endothermic and favorable; 2) -the reaction must be catalytic; 3) -the product must be produced from low cost feedstocks; and 4) -the product must have a sales price $>\$ 1.00 / \mathrm{lb}$. A price histogram of some 200 chemicals was generated indicating a bimodal distribution - a low price $(<\$ 0.85 / \mathrm{lb})$ catagory, and a higher price (> $\$ 1.00 / \mathrm{lb}$ ) catagory. An attempt was made to correlate price as a function of molecular weight and structural (complexity) factor; the latter was 4.5 times more important.

Initial examination of low cost feedstocks to high value products lead to consideration of n-paraffins to aromatics and substituted aromatics. Fifteen candidate endothermic synthesis reactions, meeting the above criteria, are suggested. The ratio of product price by reactant cost indicates $\sim 5.8$ for the best possibilities; all can be visualized as starting with low cost paraffin and methanol feedstocks.

The revised report contains an extensive section on reaction thermodynamics of the synthesis reactions, aromatic oxidation reactions, and olefin oxidation reactions, giving the pertinent thermodynamic reaction quantities as a function of temperature over the range 298-1000 K.

Presently operating commercial processes for the candidate and related reactions are discussed; including the initial reaction steps, as well as synthesis of the final products.

The investigation leads to six primary conclusions concerning, price distribution of chemicals, importance of conversion of paraffins to aromatics, alkylation-hydroxylation of the aromatic ring, reaction selection by the product price to reactant cost ratio, catalyst for optimum yield of aromatics, and the importance of olefin conversion to oxygenated products. 


\section{. TABLE OF CONTENTS .}

Executive Summary

List of Tables and Figures v v

Introduction and Background

Literature Search 2

$\begin{array}{ll}\text { Candidate Reactions } & 13\end{array}$

$\begin{array}{ll}\text { Reaction Thermodynamics } & 17\end{array}$

Synthesis Reactions \& Oxidation Reactions

Commercial Processes

Conclusions and Recommendations $\quad 42$

Selected References $\quad 43$

\section{APPENDIX}

A. Estimation of Thermodynamic Properties a-1

B. Recommended Catalysts for Endothermic Cyclization- b-1 Addition Reactions

C. Chemical Prices- CHEMICAL MARKETING REPORTER c-1 (9 June 1986)

D. Top 50 Chemicals Production Turned Back Up in 1987 d-1 (4-11-88)

E. World Chemical Outlook: USA \& Foreign Trade e-1 (12-14-87)

F. HPI's Role in Chemical's Future (Feb 1988) $f-1$

G. Catalyst Production \& Use g-1 
1 Pertinent Primary Feedstocks Data

2 Pertinent Intermediate Chemical Data $\quad 7$

$\begin{array}{lll}3 & \text { Pertinent Product Data } & 8\end{array}$

4 Pertinent Specialty Chemical Data 9

4a Chemical Structure Factors in Ascending Order 12

$5 \quad$ Favorable Synthesis Reactions 14

6 Price/Cost Ratios and Annual Production 15

7-12 Synthesis Reactions - thermodynamic calculations and 18 temperature dependent functions

13-16 Oxidation Reactions of Aromatics - thermodynamic calculations and temperature dependent functions

17-25 Oxidation Reactions of Olefins - thermodynamic calculations and temperature dependent functions Products

A-1 Benson Group Contributions to Ideal Cas Properties a-2

B-1 Recommended Catalysts for the Endothermic Cyclization- b-1 Addition Reactions

C-1 Chemical Prices

$c-1$

LIST OF FIGURES

Figure

1 Price Histogram of Chemicals 3

2 Price vs. MW Scatter Plot 4

3 Price as a Function of Mol. Wt. \& SF 4

4 Aromatics from Coal Gas and Tar Light vìl 39

5 Aromatics from Petroleum by Reforming 39 


\section{INTRODUCTION \& BACKGROUND}

Although the objective of this atudy was to recommend candidate reactions for experimentation of photo-catalytic endothermic reactions, for continulty and completeness a brief summary of past and present related work w1ll be discussed. Prevlously, Wentworth and coworkers [1] had determined an appropriate reactor configuration which would allow the direct use of high flux solar radiation to carry out endothermic chemical reaction. By implementing a Xenon lamp to imulate the full solar spectrum over a shallow $1 \mathrm{~cm}$ diameter fluldized bed reactor (relaxed bed helght of $0.5 \mathrm{~cm}$ ), Wentworth was able to compare the effects of $\mathrm{hlgh} f \mathrm{fux}$ radiation with those produced by thermal input alone. From these results it was observed that photo-catalysia produced higher ylelds and increased reaction rate constants in numerous cases than those achieved by conventional industrial processes. In lieu of these findings, it became obulous that an appropriate set of criteria should be defined and Implemented as a guldeline for future work.

The pertinent criterla for selecting candidate reactions are:

1. the reaction must be endothermic;

2. the reaction must be conventionally catalytic;

3. the product can be aynthesized from low cost feedstocks; and 4. the product must be of high $\$-v a l u e(>\$ 1.00)$. These criterion then lead to favorable economic advantages. Due to the avallability of heat induced by the direct use of solar radiation, it is advantageous to choose reactions which are endothermic in nature. High market prices of specialty chemlcals can be traced to two obvious effects: elther the product is presently synthesized 
from expensive feedstocks or the common industrial synthesis is complicated by process constraints (e.g. catalyst deactivation). Utilizing photo-catalysis could produce a high value product from an alternate cheap feedstock and may possibly overcome the inheren problems associated with standard industrial methods.

\section{LITERATURE SEARCH}

The search began by considering overall market demands in the current chemical industry [2]. The top 50 chemicals produced were reviewed and are attached in the Appendix [3]. A tabulation of chemicals with high production rates was formed. Early in the project it was expected that oxygen and nitrogen containing compounds would be of high value.

A detailed listing of price quotations of common chemicals is attached in the Appendix and was used in this project to assign a \$-value to the chemicals of interest [4]. A price histogram is presented in Figure 1. It is interesting to note that it is bl-modal, indicating a distinct separation between low and high value products at $\$ 1.00$. The first mode has a mean value of $\$ 0.4$ and the second has a mean value of $\$ 1.42$. This analysis based on current market value lead to the separation of the list as follows primary feedstocks, intermedlate chemicals, products, and specialt: chem1cals.

As presented in Figure 2, by generating a scatter plot of chemical prices versus molecular weight, it became apparent that a relationship existed. It was further suggested by Prengle [5], that this relationship was also dependent upon the complexity of 


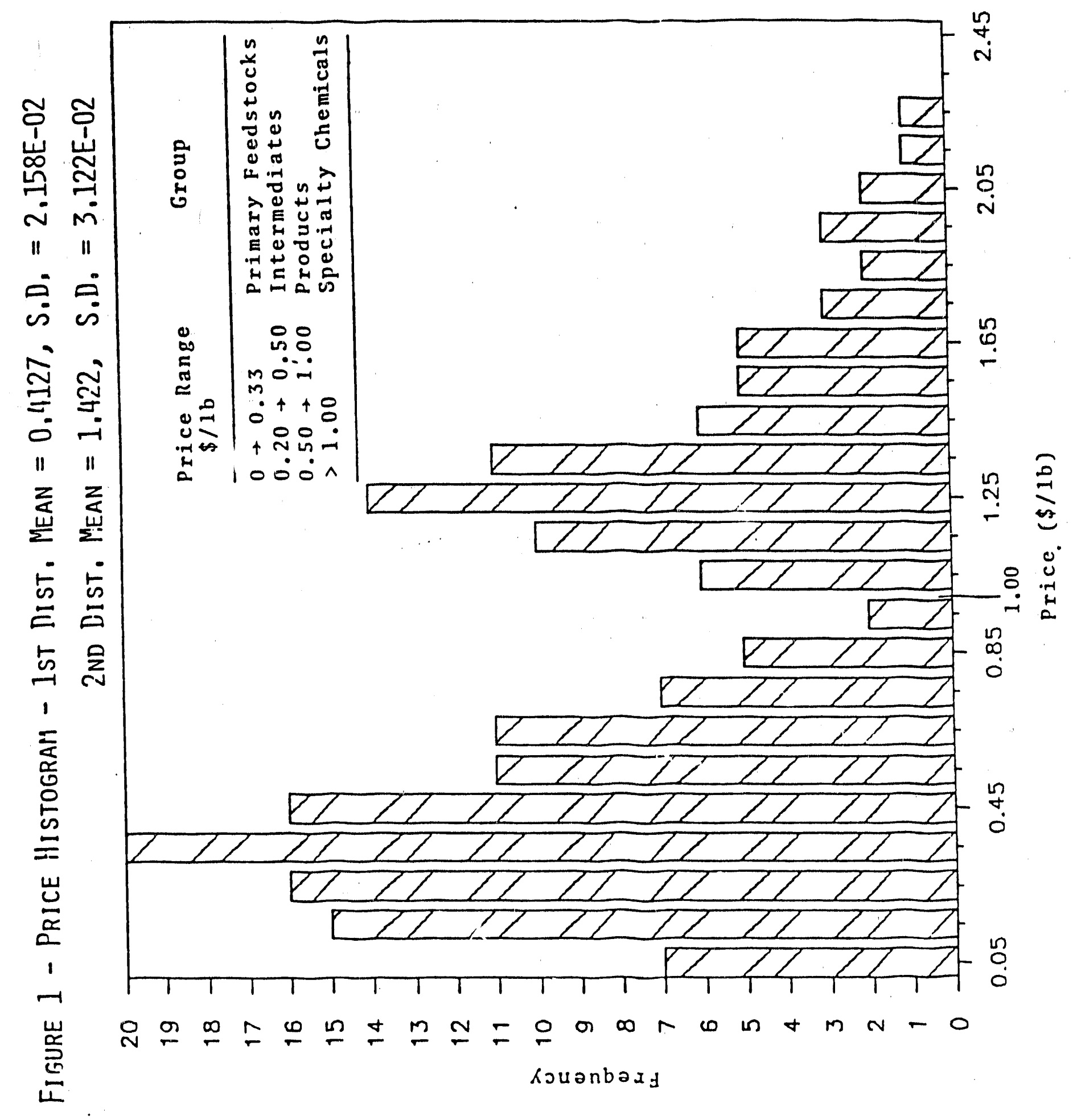


FIGURE 2 Price vs. MW Scatter Plot

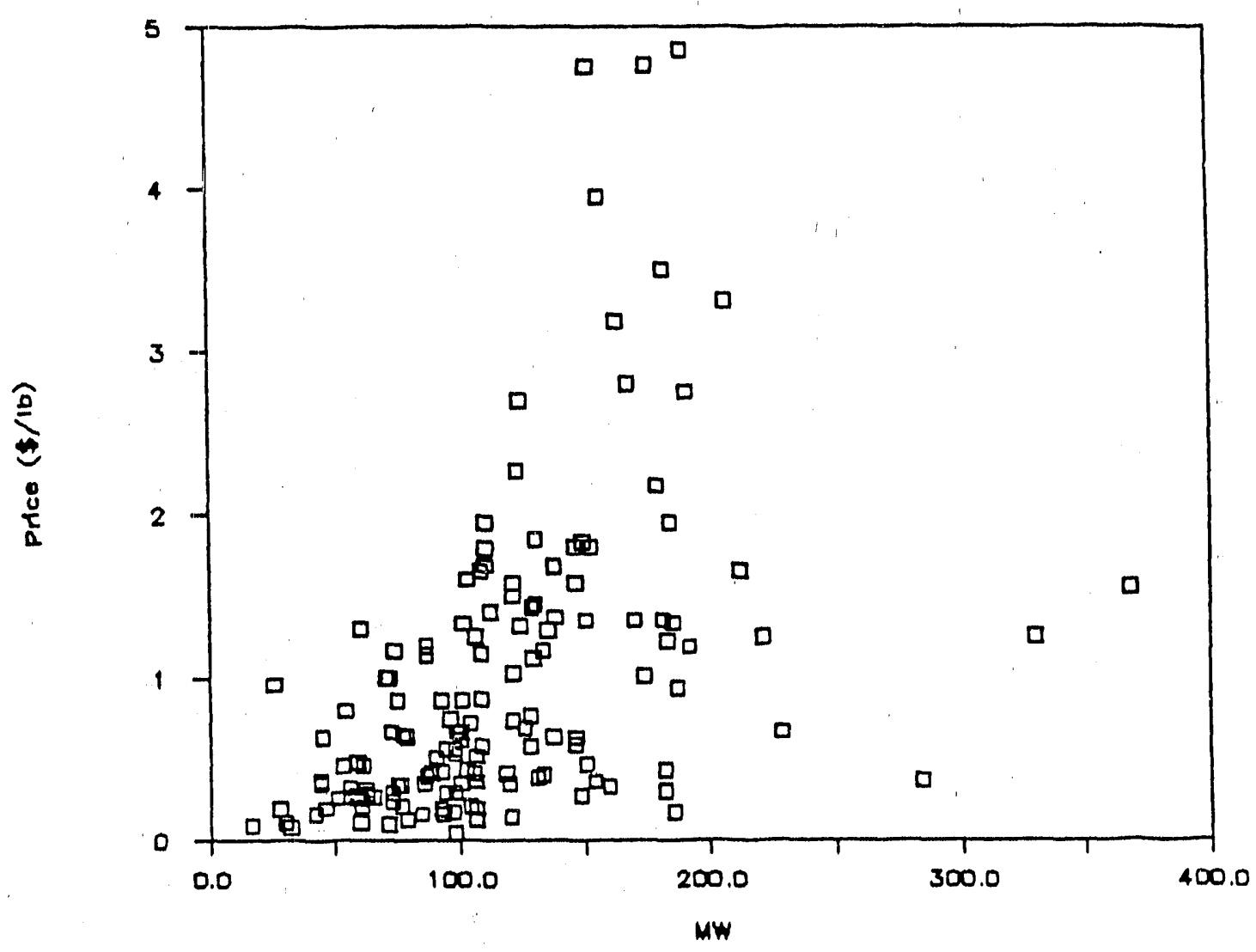

FIGURE 3 Price as a Function of Mol. Wt. \& SF

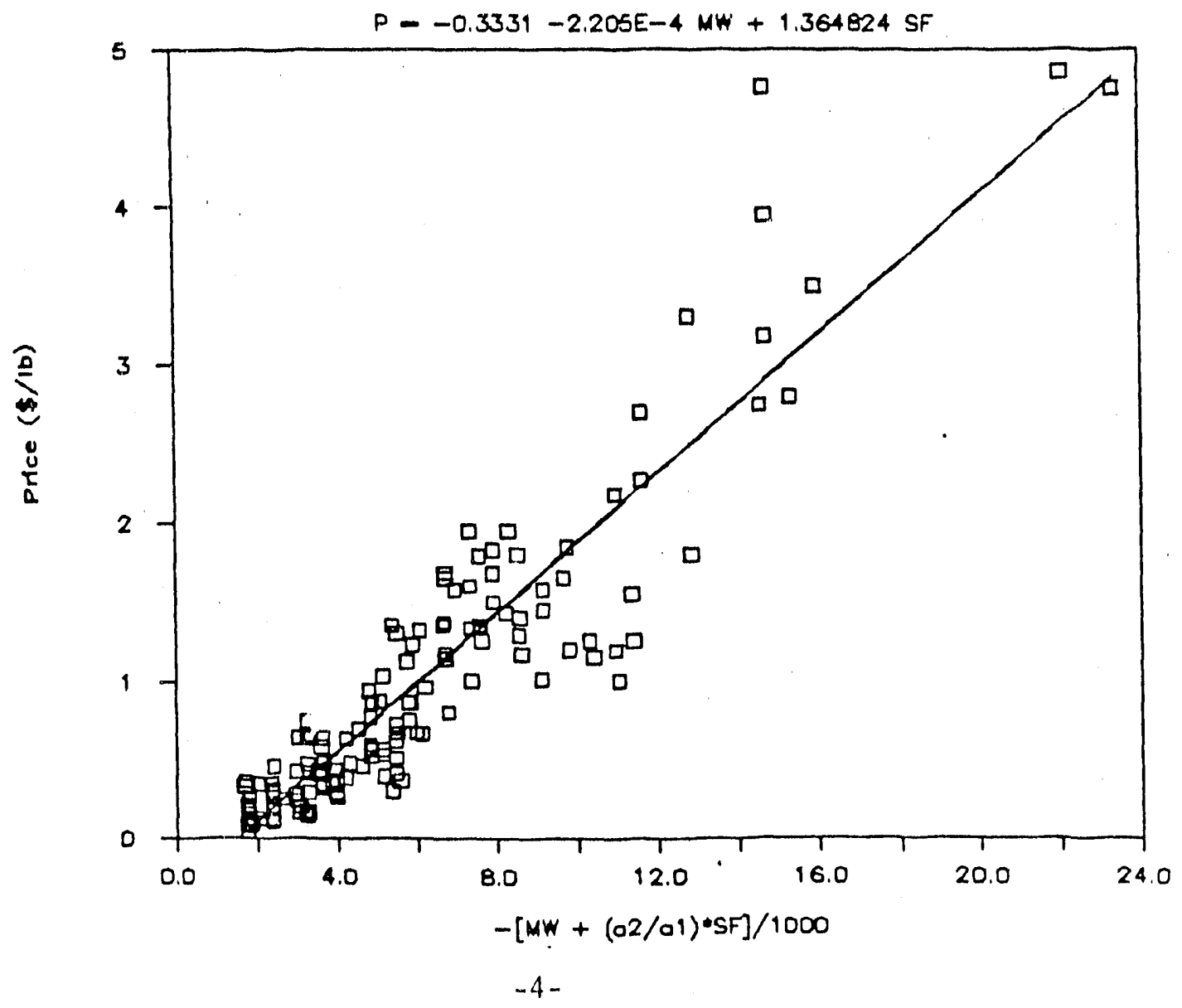


structure. The chemicals were arranged in order of complexity and assigned a structure factor. After analyzing fundamental groups, the following guldelines were chosen to agsign values to more complex compounds.

1. Stralght chain molecules were glven a value of 0.10 for $c_{1}-c_{6}$, and 0.20 for $c_{7}-4$ to each carbon in the chain. example: pentane, $\mathrm{CH}_{3} \mathrm{CH}_{2} \mathrm{CH}_{2} \mathrm{CH}_{2} \mathrm{CH}_{3} \mathrm{SF}=5(0.1)=0.50$.

2. Groups that were arranged in the 180- and tert-configuratlons were multiplied by 1.15 and 1.25 , respectively. example: Isobutane, $\mathrm{CH}_{3} \mathrm{CH}\left(\mathrm{CH}_{3}\right)_{2} \quad \mathrm{SF}=0.2+1.15(0.20)=0.43$.

3. Double bonds were accounted for by doubling the contribution. example: n-Butene, $\mathrm{CH}_{3} \mathrm{CH}_{2} \mathrm{CH}=\mathrm{CH}_{2} \quad \mathrm{SF}=2(0.20)+0.20=0.60$.

4. Halide substitutions were given a contribution of 0.10 . example: vinyl chloride, $\mathrm{CH}_{2}=\mathrm{CHCl} \quad \mathrm{SF}=2(0.20)+0.10=0.50$.

5. An aromatic ring was given a value of 0.35 . Substituents on an ortho and para directed ring were multiplied by 1.1 for ortho substituents, 1.3 for para subst1tuents, and 1.6 for meta subst1tuents. Meta directed rings were similarly multiplied by 1.1 for meta, 1.3 for ortho, and 1.6 for para. example: Dinltrophenol $\operatorname{HOC}_{6} \mathrm{H}_{3}-2,4\left(\mathrm{NO}_{2}\right)_{2} \quad \mathrm{SF}=(1.6)(1.1)(0.35+0.10+0.50)=1.67$.

6. Oxygen containing groups were given the following contributlons:' alcohols, $-\mathrm{OH}=0.10$; aldehydes, $-\mathrm{CHO}=0.30$; carboxyl1c ac1ds, $-\mathrm{COOH}=0.35$; ether, $-0-=0.425 ;$ ketones, $-\mathrm{CO}-=0.45 ;$ and esters, $-\mathrm{COO}-=0.60$. example: Acetone, $\mathrm{CH}_{3} \mathrm{COCH}_{3} \mathrm{SF}=0.45+0.20$ $=0.65$.

New structure factors should be assigned according to the guidelines above and compared to simllar structures found in Tables 
Table 1 Fertinent Frisary Feedstocks Data

\begin{tabular}{|c|c|c|c|c|c|c|c|}
\hline 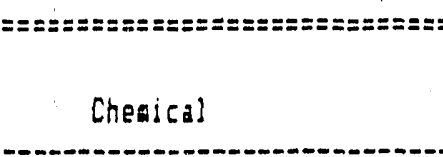 & :z=z:z=:=s= ${ }^{\prime}$ & $\begin{array}{r}\text { Price } \\
(\$ / \mid b) \\
(b-b-8 b)\end{array}$ & $M W$ & SF & $\begin{array}{c}\text { Production } \\
\text { (billion } 165 / y r) \\
(1975)\end{array}$ & $\begin{array}{l}H f(298 k) \\
\text { !k[a]/20:) }\end{array}$ & $\begin{array}{l}5 f(258 \\
i k[a] / 0\end{array}$ \\
\hline 1 Xylenes & (pet.) & & & & +5.250 & & \\
\hline -Xylene & $1,3 \cdots\left(\mathrm{CH}_{3}\right\} 2 \mathrm{C} 6 \mathrm{H} 4$ & 0.360 & 106.17 & 0.88 & & 4.12 & $28:$ \\
\hline$p-x y l e n e$ & $1,4-(\mathrm{CH} I) 2 \mathrm{C} 6 \mathrm{H}_{4}$ & 0.195 & 106.17 & 0.72 & 4.720 & 4.29 & 28. \\
\hline $0-x y l e n e$ & $1,2-(C H T) 2 C 6 H_{4}$ & 0.125 & 106.17 & 0.61 & 0.703 & 4.54 & 29. \\
\hline 2 Browide & $\mathrm{Br} 2$ & 0.330 & 159.80 & 0.20 & $0.4 c 8$ & 0.00 & 0.1 \\
\hline 3 Isabutylenes & $(\mathrm{CH}) 2 \mathrm{C}=\mathrm{CH} 2$ & 0.320 & 56.10 & 0.63 & 0.550 & -1.67 & 15. \\
\hline 4 Fhospharic Acid & HIPOA & 0.290 & 98.00 & 0.40 & $21.8 E 7$ & & \\
\hline s n-Eutenes & $\mathrm{CH} 3 \mathrm{CH} 2 \mathrm{CH}=\mathrm{CH}$ & 0.260 & 56,12 & 0.60 & 1.480 & -1.67 & 15. \\
\hline 6 Ethy! Alcohol & CHJCH2OH & 0.194 & 46.07 & 0.30 & 1.429 & -56.12 & -40. \\
\hline 7 Toluene & C6HSCH3 & 0.190 & 92.13 & 0.45 & $\$ 4.990$ & 11.95 & 29. \\
\hline 8 Ethylene & $\mathrm{CH} 2=\mathrm{CH} 2$ & 0.185 & 28.05 & 0.40 & $\$ 30.550$ & 12.50 & 16. \\
\hline Q Ethylerie Dibronide & $\mathrm{BrCH}=\mathrm{CHER}$ & 0.170 & 185.85 & 0.60 & 0.275 & & \\
\hline 10 Ethiylene Dichloride & $C I C H=[H[S]$ & 0.170 & 96.94 & 0.65 & +13.630 & 0.30 & 5. \\
\hline 11 Fropjlenie & $\mathrm{CH}_{2}=\mathrm{CH}=\mathrm{H} 3$ & $0 .: 50$ & 42.08 & 0.50 & $* 14.93$ & 4.33 & 14. \\
\hline $12[t-c]$ faraftine & & 0.150 & & & $\$ 4.41$ & & \\
\hline n-Hexañe & CHJ $(C H 2)$ ACHT & & EL.i7 & 0.52 & & $-30,9 t$ & 0. \\
\hline heptane & $\mathrm{CH} 3(\mathrm{CH} 2) 5 \mathrm{SH} 3$ & & 100.17 & 0.57 & & -44.85 & 1. \\
\hline 13 Cyeloherarie & Cthi12 & 0.250 & 54.16 & 0.60 & 11.740 & -27.43 & 7. \\
\hline 14 Cumene & (EHI) ZCHCEHE & 0.145 & 120.20 & 0.55 & $\$ 3.330$ & 0.94 & 32. \\
\hline 15 Eenzena & CEHE & 0.123 & 7૬.:1 & 0.35 & 19.730 & $19.8:$ & $3 i$. \\
\hline It Urea & H2NCCNH: & 6.107 & 60.66 & 0.40 & $\$ 13.110$ & -58.70 & $-3 t$. \\
\hline 17 Formaidetiyde & $\mathrm{H}=\mathrm{HO}$ & 0.106 & $? \hat{0.65}$ & 0.30 & $\$ 5.700$ & -27.70 & $-2 t$. \\
\hline 18 Nornal Faíaftins & {$[n+2 n+2$} & $0.65-0.10$ & & & 0.615 & & \\
\hline Methiane & Cit4 & & 16.04 & 0.10 & & -17.88 & -12. \\
\hline Ethane & Chosus & & 30.07 & 0.26 & & -26.24 & -7. \\
\hline fropañe & CHSAHZCH: & & $44.0 \mathrm{C}$ & 0.3 & & $-24.5 i$ & -5 \\
\hline n-Eutana & CHIICHEIZLHZ & & 50.12 & 0.49 & & -29.81 & -3. \\
\hline n-fentare & Chis(CHiz):ZHS & & 72.15 & $0.5)$ & & -35.60 & $-i$ \\
\hline 19 LF'S & & 0.100 & & & 220.64 & & \\
\hline 20 Enlorine & $\mathrm{C:2}$ & 0.098 & 70.91 & 0.20 & 20.903 & 0.10 & 0. \\
\hline 21 Bor $a \breve{~}$ & $\mathrm{NaSE} 407.10420$ & 0.096 & & & 1.247 & & \\
\hline 2i ARTiznia & NHT & 0.005 & 17.05 & 0.15 & 32.400 & -16.92 & $\because$ \\
\hline 22 Si gasoiıne & & 0.081 & & & 196.875 & & \\
\hline $2 j$ Yiethanol & $\mathrm{CHOOH}$ & 0.079 & 32.04 & 0.20 & 5.980 & -45.68 & -5 \\
\hline 24 íerosene & & 0.056 & & & 2.356 & & \\
\hline 25 tieating Oil (No. 2 ) & & 0.049 & & & 5.623 & & \\
\hline 26 figeidual Fued bil (No. b) & & $0.04 !$ & & & 1.735 & & \\
\hline 27 Natural Eas & & $0.029-0.0477$ & & & & & \\
\hline $\begin{array}{l}2 E \text { Eulfuric Acid } \\
29 \text { Coal }\end{array}$ & H2S04 & $\begin{array}{c}0.038 \\
0.014-0.028\end{array}$ & 95.05 & 0.30 & 79.218 & -199.45 & -154. \\
\hline
\end{tabular}

NOTE: I indicates current figure $(t-t-8 t)$

() indicated estiated figure 
Taule 2 Pertinent Interatiate Cheaical Data

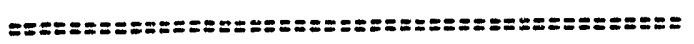

Price

(s/Jb)

Chenical

1 Nonylahenol, Ethoxylated

2 Triethanolanine

- ropulene oride

4 Triethylene 6lycol

5 Monoethangl anine

(2-Asinoethane])

6 Acrylonitrile

7 Linear Alkytenzenes

8 Acetic Anhydride

9 Diritrotol:sne

10 Aniline

10 Ethylene Glycol Konobuty! Ether

11 Diethanolarine

11 Ethiy! Azetaie

12 nethil Chlorefere (1,1,1-Trichicr sethane:

13 Fid bodecy: Prithalata

14 Vinyi Acetete

15 Trichioroethyiene

It Etearit hede

17 Acetalyoehride

IE Cartor Tetraehioride

:5 Ethilenediariane ietradezt:s ha:d (Evithi

20 Hethiderie Crictide Dictilurerietting:

2i Ketrin lsotut,i letore (4-Metro)-?-fentanitie)

22 Ethilere dxide

2I Eniorstisa

24 n-Euty! fllcoho!

as Etrijlene Giyzol Monsiusthyl Ether

26 ferchioroethyierie lietractilordethylene:

27 Ethilene 6lyol

LE Sortitol

25 n-Eutyraldehide

30 Shene!

31 Vinyl Chidorida

32 Acetnrie

33 Fhthalis Artiydrioe

34 Ethyl Chloride

is Methyl Chloride

It Aretic Acid

3? Lignosulfonates

Je Yethiy! Ethy: lietone (i-Butanore:

is Ethulteñiene

16 Styrene

4i Carben Dicultadz

Q2 Iscpicpyl hisotol

\begin{tabular}{|c|}
\hline 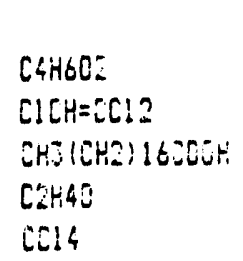 \\
\hline
\end{tabular}

Syabol $(6-6-86)$

0.490

СSH9N

ish 60

(CH:OCH2CH2CH) 2

H2NCH2CH2OH

CIHIN

C4K603

C7HitH204

C6H7N

HOCH2CHZOCAH4

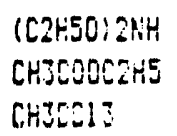

Chisens:

CHovi:

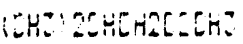

Corite

Chin?

CAtios

HOCriag:T2OCH:

84.93

0.75

$10 \therefore 20$

6.95

0.350

44.05

0.345

19.39

74.12

0.245

$76 .:$ :

6.65

0.48

0.50

0.5 .5

0.310

HESTERHOH

Ceril40s

CAHED

Cétiés

HEC =CHC!

rHiseach:

CEn̈40:

C245Cl

Chijel

CHJEOSH

Chüraceris:

Ceti:-rich?

CEHEEH $=$ Cria

CS2

(CH?) $2 \mathrm{CHOH}$.

0.310

62.07

0.300

0.295

[E2.17

72.10

0.280

145.12

0.270

0.270

$0.2 \leq 5$

0.200

0.250

0.250

i. 235

0.236

0.216

$: 00 .: 7$

$0.21:$

109.16

$0.26 \mathrm{t}$
Production

ibillion lbs/yr) Hf(2FEk) Gf (293ki) (6-6-86) (kad/sol) (leal/6o!)
5.092

0.089

$+1.880$

0.088

0.083

$+2.350$

0.495

1.458

0.273

0.407

0.131

0.086

0.171

0.457

$-17.3$

$-105.86$

$-37,2$

17.23

$-76.25$

$-18.52$

0.116

$\$ 2.110$

0.253

0.054

0.900

0.906

0.050

0.497

-Z.E

$-16.40$

$\therefore .50 \quad-52.50(2)$

*5. 57

$-1250$

$-24.20$

$-3.95$

6.490

$-65.5 ?$

$-16.35$

0.080

6.679
0.40

0.50

0.70

$94 .: \therefore$

0.45

62.50

58.68

0.50

64.52

0.65

0.5)

50.49

i. 6

0.26

60.05

6.45

72.12

0.75

0.55

0.75

$\therefore .30$

14.6E:

0.134

$\therefore .606$

2.7E:

$+2.720$

$+.803$

0.762

0.575

0.366

12.680

0.945

0.425

$-95.65$

$-20.00$

$-25.010$

$-23.05$

8.44

$-52.60$

-1 iv.li

$-2 i .76$

$-19.3$

$-163.95$

76.13

$0\} .11$

$6.4 \%$
$-56.97 \quad-34.91$
$\$ 8.55 i$

7.22

32.21

17.45:

25.9

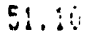

0.479

$2 \div .95$

15.99

$4 ! .1: 3$

$-65.15$

$-4: .15$ $\because 2.7$

$-2=0.0$

$-2.43$

$-7.36$

12. $3 !$

$-j=.5$ ?

$-79.12$

$-14.34$

$-12.72$

9.63

HCTE: Inícates current figure $(b-6-8 b)$ 
Table 3 Pertidest Prodoct Data

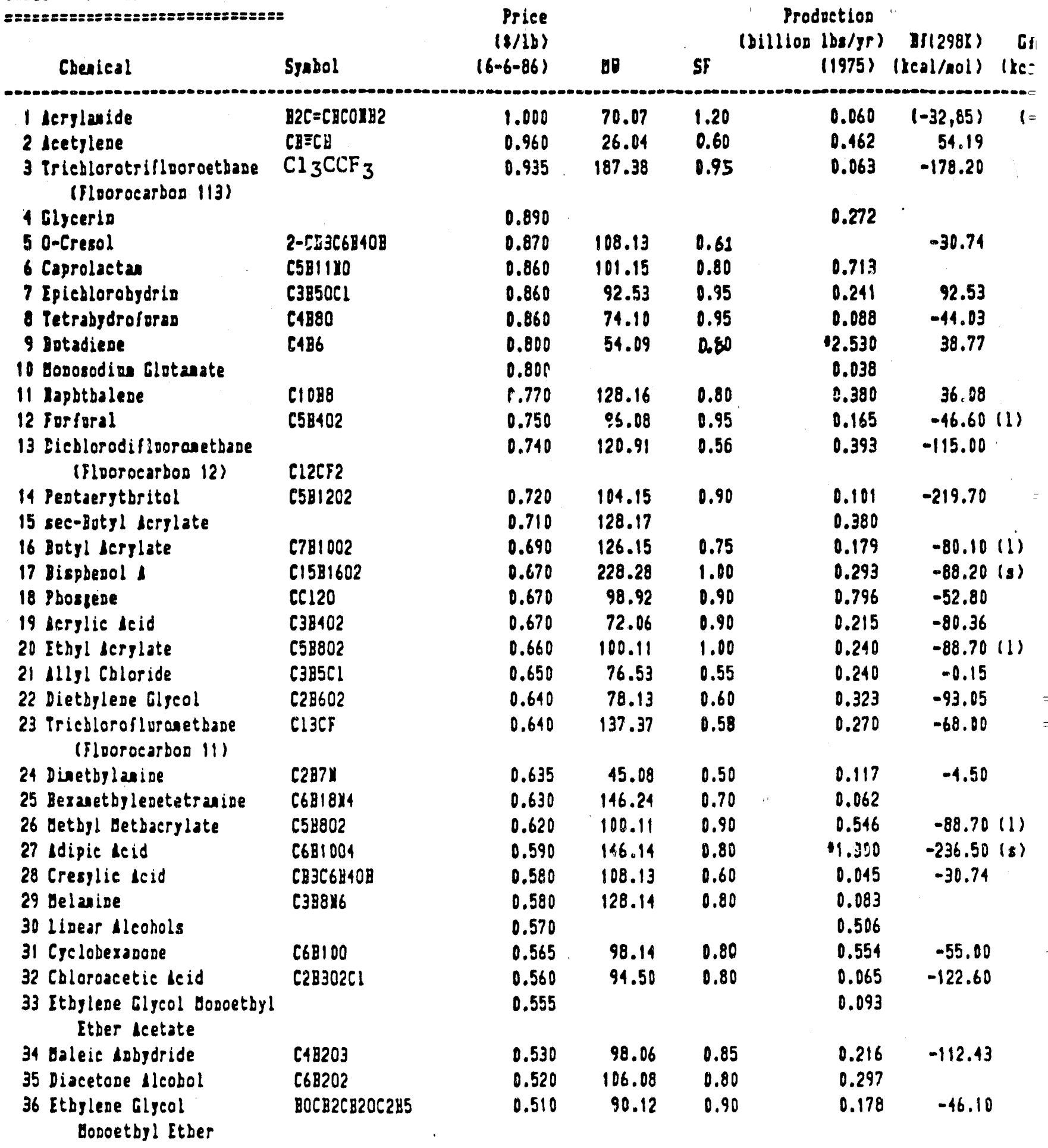

MOTE: Indicates corrent figore (6-6-86)

() Indicated estinated figore 
Table 4 Pertipent Specialty Cbenical Data

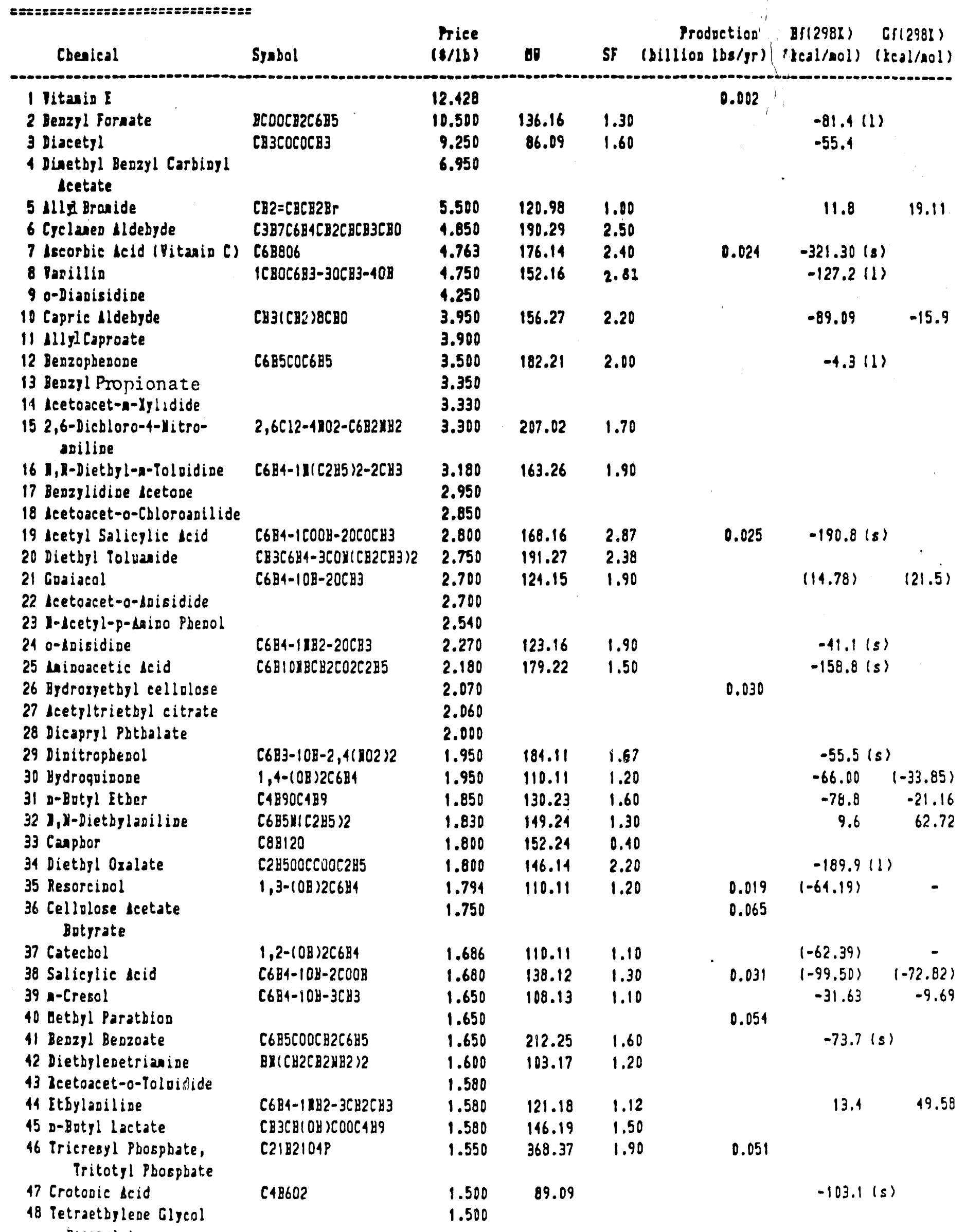


Table 4 Pertineat Specialty Chenical Data

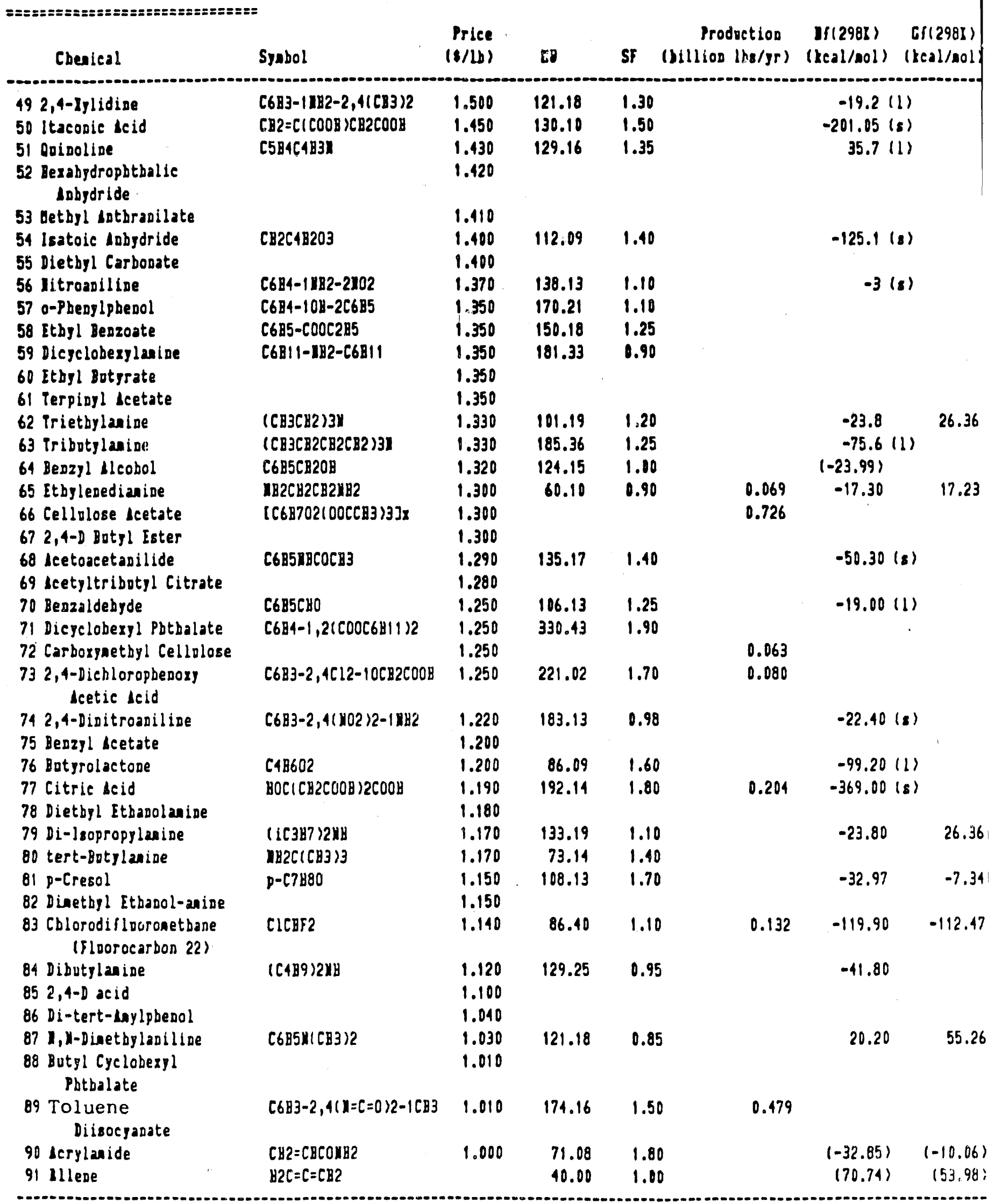

10TE: - indicater current figore (6-6-86)

(1) indicated estinated figore 
1-4. Examples in ascending order, covering the entlre sf-range are shown in Table $4 a$.

Price can be described as follows

$P(\$ / 1 b)=20+21 * M W+22 * S F$

After rearranging equation ( 1 ) can be written as

$$
P(\$ / 1 b)=20+21\left(M W+\frac{a 2}{a 1} S F\right)=20+21 * X
$$

Figure 3 represents price correlated as a function of molecular welght and structure factor revealing a linear relationship with a coefficient of regression of 0.901 . This correlation 18 useful in estimating market value of compounds not included in this report.

It was necessary to obtain thermodynamic data to calculate the heat of formation and ground-state free energy values at desired temperatures. Data avaliable in the literature was first obtained and then the method of Benson (described in the Appendix) was chosen to estimate unknown properties [6-8]. This data was needed to calculate heat of reactions and ground stato free energles of candidate reactions found throughout the 11terature [9-12]. Tables 1-4 present a summary of all pertinent chemical data obtained in the search. 
Table 4a Chemical Structure Factors in Ascending Order

Compound

1) Methane

2) Ammonia

0.15

3) Chlorine

4) Formaldehyde

5) Benzene

6) Ethylene

7) Acetic Acld

8) Propylene

9) Cumene

10) Methyl

Chloroform

11) Trichloroethylene

12) Ethylene Glycol Monoethyl Ether

13) Butadiene

14) Ethylaniline

15) Ethyl Benzoate

16) N,N-Diethylandiline

17) Dlacetyl

18) Dinftrophenol 1.67

19) 2,6-Dichloro-4- 1.70 Nitroaniline

20) Vanilin

\section{SF}

0.10

0.20

0.30

0.35

0.40

0.45

0.50

0.55

0.60

0.73

0.93

0.80

1.12

1.25

$1 \cdot 31$

1.60

2.81
Molecular Structure Comment

$\mathrm{CH}_{4}$, simplest carbon molecule

$\mathrm{NH}_{3}$, simplest amine group

Cl-Cl, diatomic Halogen

HCHO, simple aldehyde

$\mathrm{C}_{6} \mathrm{H}_{6}$, simple aromatic

$\mathrm{H}_{2} \mathrm{C}=\mathrm{CH}_{2}$, stralght chain olefin methyl group propyl substituent on ethane

$\mathrm{HOCH}_{2} \mathrm{CH}_{2} \mathrm{OC}{ }_{2} \mathrm{H}$, ether group group in the meta position

groups attached to Nitrogen
$\mathrm{CH}_{3} \mathrm{COOH}$, carboxyllc acld attached to a

$\mathrm{H}_{2} \mathrm{C}=\mathrm{CHCH}_{3}$, stralght chain olefin

$\mathrm{C}_{6} \mathrm{H}_{5}-\mathrm{CH}\left(\mathrm{CH}_{3}\right)_{2}$, benzene ring with 180-

$\mathrm{CH}_{3} \mathrm{C}(\mathrm{Cl})_{3}$, tetrachlorine conflguration

ClCH=CCla, stralght chain olefin with 3 halogens, one 1so-conflguration

$\mathrm{CH}_{2}=\mathrm{CHCH}=\mathrm{CH}_{2}$, straight chain diene

$\mathrm{C}_{6} \mathrm{H}_{4}-1 \mathrm{NH}_{2}-3 \mathrm{CH}_{2} \mathrm{CH}_{3}$, aniline with ethyl

$\underset{\text { group }}{\mathrm{C}_{6} \mathrm{H}_{5} \mathrm{COOC}_{2} \mathrm{H}_{5} \text {, benzolc ester with ethyl }}$

$\mathrm{C}_{6} \mathrm{H}_{5} \mathrm{~N}\left(\mathrm{C}_{2} \mathrm{H}_{5}\right)$, aniline with 2 ethyl $\mathrm{CH}_{3} \mathrm{COCOCH}_{3}$, diketone with 2 methyl
groups

$\mathrm{C}_{6} \mathrm{H}_{3}-1 \mathrm{OH}-2,4\left(\mathrm{NO}_{2}\right)_{2}$, phenol with 2 nitr groups in the ortho and para positions $2,6 \mathrm{Cl}_{2}-4 \mathrm{NO}_{2}-\mathrm{C}_{6} \mathrm{H}_{2}-\mathrm{NH}_{2}$, aniline with $\mathrm{NO}_{2}$
group in the para position and $2 \mathrm{Cl}$ groups both in the ortho position

4 CHOC $_{6} \mathrm{H}_{3}-20 \mathrm{C}^{\prime} 3^{-10 \mathrm{H}}$, phenol with an aldehyde and an ester group attached 1 r the ortho and para positions 


\section{CANDIDATE REACTIONS}

Fifteen (15) possible candidate endothermic chemical reactions, listed in Table 5, were chosen and examined thermodynamically, using "ground state" enthalpies and free energies of reaction. More detailed summaries of the thermodynamic values are presented by Tables 7-16 incl. in the section on Reaction Thermodynamics.

The reactions utilize the feedstock compounds of $\mathrm{n}$-hexane, benzene, toluene, methanol, ammonia, water, and hydrogen bromide. The product compounds include benzene, toluene, phenol, aniline, resorcinol, cresols, salicylic acid, acetanilide, benzaldehyde, benzyl alcohol, and others. Cyclizationaddition reactions of $n$-parafins to aromatics, and n-paraffins plus methanol to alkylated and hydroxylated aromatics, 100k feasible and produce valuable products. Possible catalysts for these reactions, which are photo-activated, are the transition metal oxides of titanium, vanadium, chromium, and molybdenum, especially $\mathrm{V}_{2} \mathrm{O}_{5}$. Other possible catalysts are mentioned in Appendix B.

As a discriminator of the product cost advantage, the product price to reactant(s) cost ratio is proposed, and values are presented in Table 6 . In general rexctions were sought that would give ratios of 5 to 10 . It will be noted that cresols, resorcinol, benzaldehyde, benzyl alcohol, guaiacol, and ethyl aniline fall in this range of values.

As experimental reaction rate data are obtained, this list of favorable reactions (high conversion and selectivity) will be shortened and process possibilities will come into sharper focus. 
TABLE 5 - Favorable Synthesis Reactions

\begin{tabular}{|c|c|c|c|c|}
\hline Reaction & Products & $\Delta H_{R}^{\circ}(298)$ & $\Delta H_{\mathrm{R}}^{\circ}(500)$ & $\begin{array}{r}\text { Product Valu } \\
(\$ / 1 \mathrm{~b})\end{array}$ \\
\hline 1) $\mathrm{n}-\mathrm{C}_{6} \mathrm{H}_{24}$ & benzene & 59.78 & +62.02 & 0.123 \\
\hline 2) $\mathrm{n}-\mathrm{C}_{6} \mathrm{H}_{34}+\mathrm{CH}_{3} \mathrm{OH}$ & $\begin{array}{l}\text { Q } \\
\text { toluene }\end{array}$ & 42.17 & 44.95 & 0.190 \\
\hline 3) $\mathrm{n}-\mathrm{C}_{6} \mathrm{H}_{14}+\mathrm{CH}_{3} \mathrm{OH}$ & $\begin{array}{l}\text { DoH } \\
\text { phenol }\end{array}$ & 47.12 & 49.98 & 0.290 \\
\hline 4) $\mathrm{n}-\mathrm{C}_{6} \mathrm{H}_{14}+\mathrm{NH}_{3}$ & $\begin{array}{l}\text { D-NH } \\
\text { aniline }\end{array}$ & 71.65 & 74.90 & 0.420 \\
\hline 5) $\mathrm{n}-\mathrm{C}_{6} \mathrm{H}_{14}+2 \mathrm{CH}_{3} \mathrm{OH}$ & $\begin{array}{c}\mathrm{C}_{\mathrm{OH}}^{\mathrm{OH}} \\
\text { Resorcinol }\end{array}$ & 31.24 & 36.35 & $\begin{array}{ll}\text { p } & 1.950 \\
m & 1.790 \\
0 & 1.686\end{array}$ \\
\hline 6) $\mathrm{C}_{6} \mathrm{H}_{5} \mathrm{CH}_{3}+\mathrm{H}_{2} \mathrm{O}$ & $\begin{array}{l}\qquad \lambda_{\mathrm{OH}}^{\mathrm{CH}_{3}} \\
0 \text {-cresol }\end{array}$ & 15.88 & 16.67 & $\begin{array}{ll}\Gamma & 1.150 \\
\text { in } & 1.650 \\
0 & 0.870 \\
\end{array}$ \\
\hline 7) $\mathrm{nC}_{6} \mathrm{H}_{14}+\mathrm{CH}_{3} \mathrm{OH}$ & $\underset{\mathrm{m} \text {-cresol }}{-2 \mathrm{OH}_{3}}$ & 56.41 & 59.97 & $"$ \\
\hline 8) $\mathrm{C}_{6} \mathrm{H}_{5} \mathrm{OH}+\mathrm{CO}_{2}$ & salicylic acid & 17.58 & 16.04 & 1.680 \\
\hline 9) $\mathrm{C}_{6} \mathrm{H}_{5} \mathrm{NH}_{2}+\mathrm{CH}_{3} \mathrm{CHO}$ & $\begin{array}{l}\mathrm{CH}=\mathrm{CONH}-1 \\
\text { acetanilide }\end{array}$ & 2.72 & 4.30 & 1.29 \\
\hline 10) $\mathrm{C}_{6} \mathrm{H}_{5} \mathrm{CH}_{3}+\mathrm{H}_{2} \mathrm{O}$ & $\begin{array}{l}\text { (1) CHO } \\
\text { benzaldehyde }\end{array}$ & 27.85 & 29.08 & 1.25 \\
\hline 11) $\mathrm{C}_{6} \mathrm{H}_{6}+\mathrm{CH}_{3} \mathrm{OH}$ & $\begin{array}{r}-\mathrm{CH}_{2} \mathrm{OH} \\
\text { benzyl al cohol }\end{array}$ & 4.27 & 6.87 & 1.32 \\
\hline 12) $\mathrm{C}_{6} \mathrm{H}_{5} \mathrm{CH}_{3}+\mathrm{NH}_{3}$ & $\frac{\Delta \mathrm{Cll}_{3}}{\mathrm{NH}_{2}}$ & 19.37 & 21.18 & 1.50 \\
\hline $13 \mathrm{C}_{6} \mathrm{H}_{5} \mathrm{OH}+\mathrm{CH}_{3} \mathrm{OH}$ & $\begin{array}{c}\mathrm{N}_{\mathrm{OCH}_{3}}^{\mathrm{OHI}} \\
\text { guaiacol }\end{array}$ & 11.91 & 11.78 & 2.70 \\
\hline 14) $\mathrm{CH}_{2}=\mathrm{CHCH}_{3}+\mathrm{HBr}$ & $\begin{array}{r}\mathrm{CH}_{2}=\mathrm{CHCH}_{2} \mathrm{Br} \\
\text { al1y bromide }\end{array}$ & 15.58 & 16.29 & 5.50 \\
\hline 15) $\mathrm{n}-\mathrm{C}_{8} \mathrm{H}_{18}+\mathrm{NH}_{3}$ & ethylanilinc & 74.14 & 76.51 & 1.58 \\
\hline
\end{tabular}


TABLE 6 - Price/Cost Ratios and Annual Production

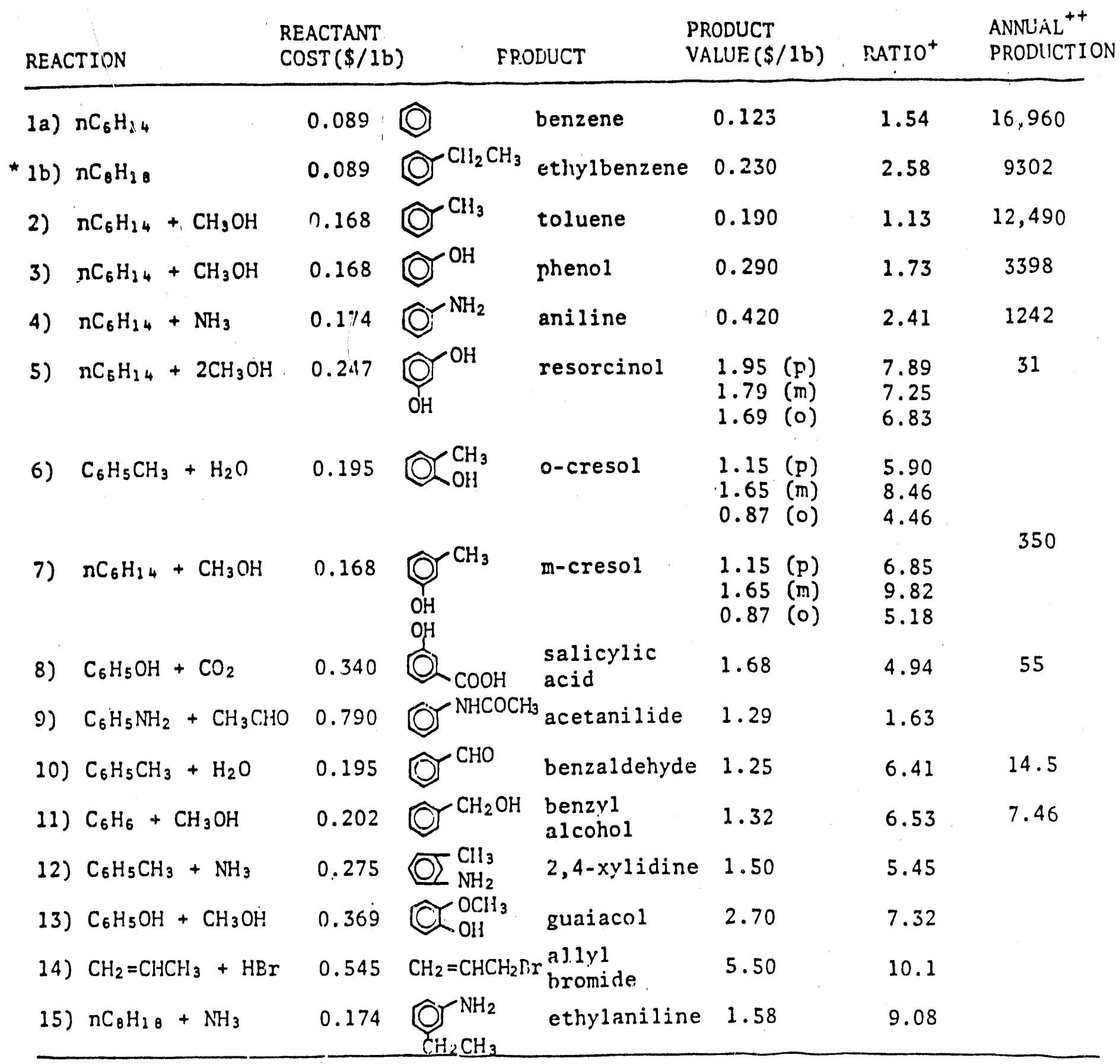

* added to table

+ Product Price/Reactant(s) Cost

$+10^{6} 1 \mathrm{bs} /$ year 


\begin{tabular}{ll} 
REACTANTS & $\mathrm{COST}$ \\
\hline $\mathrm{nC}_{6} \mathrm{H}_{14}$ & $\left(\frac{\$ 21.63}{\mathrm{bbl}}\right)^{(1)}\left(\frac{\mathrm{bbl}}{42 \mathrm{gal}}\right)\left(\frac{\mathrm{gal}}{19.28 \mathrm{ft}^{3}}\right)^{(2)}\left(\frac{3.322 \mathrm{ft}^{3}}{1 \mathrm{~b}}\right)^{(2)}=\$ 1.089 / 1 \mathrm{~b}$ \\
$\mathrm{CH}_{3} \mathrm{OH}$ & $\$ 0.079 / 1 \mathrm{~b}$ \\
$\mathrm{NH}_{3}$ & $\$ 0.085 / 1 \mathrm{~b}$ \\
$\mathrm{H}_{2} \mathrm{O}$ & $\$ 0.005 / 1 \mathrm{~b}$ \\
$\mathrm{C}_{6} \mathrm{H}_{5} \mathrm{CH}_{3}$ & $\$ 0.190 / 1 \mathrm{~b}$ \\
$\mathrm{C}_{6} \mathrm{H}_{5} \mathrm{OH}$ & $\$ 0.290 / 1 \mathrm{~b}$ \\
$\mathrm{C}_{6} \mathrm{H}_{5} \mathrm{NH}_{2}$ & $\$ 0.420 / 1 \mathrm{~b}$ \\
$\mathrm{CH}_{3} \mathrm{CHO}^{2}$ & $\$ 0.370 / 1 \mathrm{~b}$ \\
$\mathrm{C}_{6} \mathrm{H}_{6}$ & $\$ 0.123 / 1 \mathrm{~b}$ \\
$\mathrm{CH}_{2}=\mathrm{CHCH}$ & $\$ 0.160 / 1 \mathrm{~b}$ \\
$\mathrm{HBr}_{3}$ & $\$ 0.385 / 1 \mathrm{~b}$ \\
$\mathrm{nC}_{8} \mathrm{H}_{18}$ & $\$ 0.089 / 1 \mathrm{~b}$ \\
$\mathrm{CO}_{2}$ & $\$ 0.050 / 1 \mathrm{~b}(3)$ \\
- & \\
\hline
\end{tabular}

(1) "Statistics", Oil and Gas Journal, October 19, 1987.

(2) "Engineering Data Book", 9th ed., Gas Processors Suppliers Association, pp. $16-3$ (1972).

(3) Price quoted from Liquid Carbonics $\mathrm{CO}_{2}$ Corporation, Houston, TX.

-.- All other prices were obtained from "Chemical Prices", Chemical Marketing Reporter, Schnell Publishing Company, Inc., New York, pp. 32-39, June 9, 1986 . 


\section{REACTION THERMODYNAMICS}

In order to determine the temperature effects on the reactions of interest, detailed "ground state" thermodynamic calculations are presented in this section, Tables 7-25. Values of the enthalpy and Gibbs free energy of formation, the $\Delta C_{p}^{\circ}$ of reaction, and $\ln K_{a}$, from 298 to $1000 \mathrm{~K}$ are presented; along with the temperature dependent functions. The Tables are divided into three (3) reaction groups: synthesis, oxidation of aromatics, and oxidation of olefins.

i) Tables 7-12 incl. - synthesis reactions; dehydrocyclization, alkylation, and hydroxylation. It will be noted, that overall the dehydrocyclization plus alkylation and hydroxylation of n-paraffins is endothermic; whereas, the alkylation and hydroxylation of aromatics separately or combined are exothermic. In other words, the chemical conversion of n-paraffins to aromatics being endothermic is a key to the utilization of solar energy during the day time.

2) Tables 13-16 incl. - oxidation reactions of aromatics. Last year (1987) Professor Prengle suggested that to produce a cost effective commercial process a combination of day-time (endothermic) and night-time (exothermic) reactions would be required. Also that certain oxidation reactions leading to single step conversion products of high value, or multistep conversions to heterocyclic products of high value should be used. Amongst the simple oxidation products of aromatics are: aldehydes and acids. An important reaction in this series is the first, Table 13, the partial oxidation of toluene to benzaldehyde; the latter being a high value product.

3) Tables 17-25 incl. - oxidation reactions of olefins. The conversion of $n$-paraffins to aromatics results also in the production of a significant fraction of olefins (ethylene and propylene), which must be converted to high value products as wel1. Therefore, partial oxidation reactions for this group of compounds is pertinent. Reaction to aldehydes, epoxides, glycols, alcohol, and ketone are presented along with pertinent thermodynamic values. It will be noted that the formation of aldehydes and epoxides are highly favorable.

The attached tables present numerous reactions, in the above three categories, from which a number of day-time night-time sequences can be selected, for experimental study. The ultimate choice of the specific reactions will depend on the experimental results, and where there are choices, will depend on maximizing the $\$$-value of the products. In this latter connection Table 26 presents the Price/Cost ratios and annual production for the oxidation products of aromatics and olefins. 
TABLE 7 - Dehydrocyclization and Hydroxylation of n-Heptane to o-Cresol

1) $\mathrm{n}-\mathrm{C}_{7} \mathrm{H}_{16}+\mathrm{C}_{7} \mathrm{H}_{8}+4 \mathrm{H}_{2}$

2) $\mathrm{C}_{7} \mathrm{H}_{8}+\mathrm{CH}_{3} \mathrm{OH}+\mathrm{C}_{7} \mathrm{H}_{8} \mathrm{O}+\mathrm{CH}_{4}$

Overal1: $\quad \mathrm{n}-\mathrm{C}_{7} \mathrm{H}_{16}+\mathrm{CH}_{3} \mathrm{OH} \rightarrow \mathrm{H}_{4} \mathrm{C}_{6} \underset{\gamma}{-\mathrm{CH}_{3}}+\mathrm{CH}_{4}+4 \mathrm{H}_{2}$

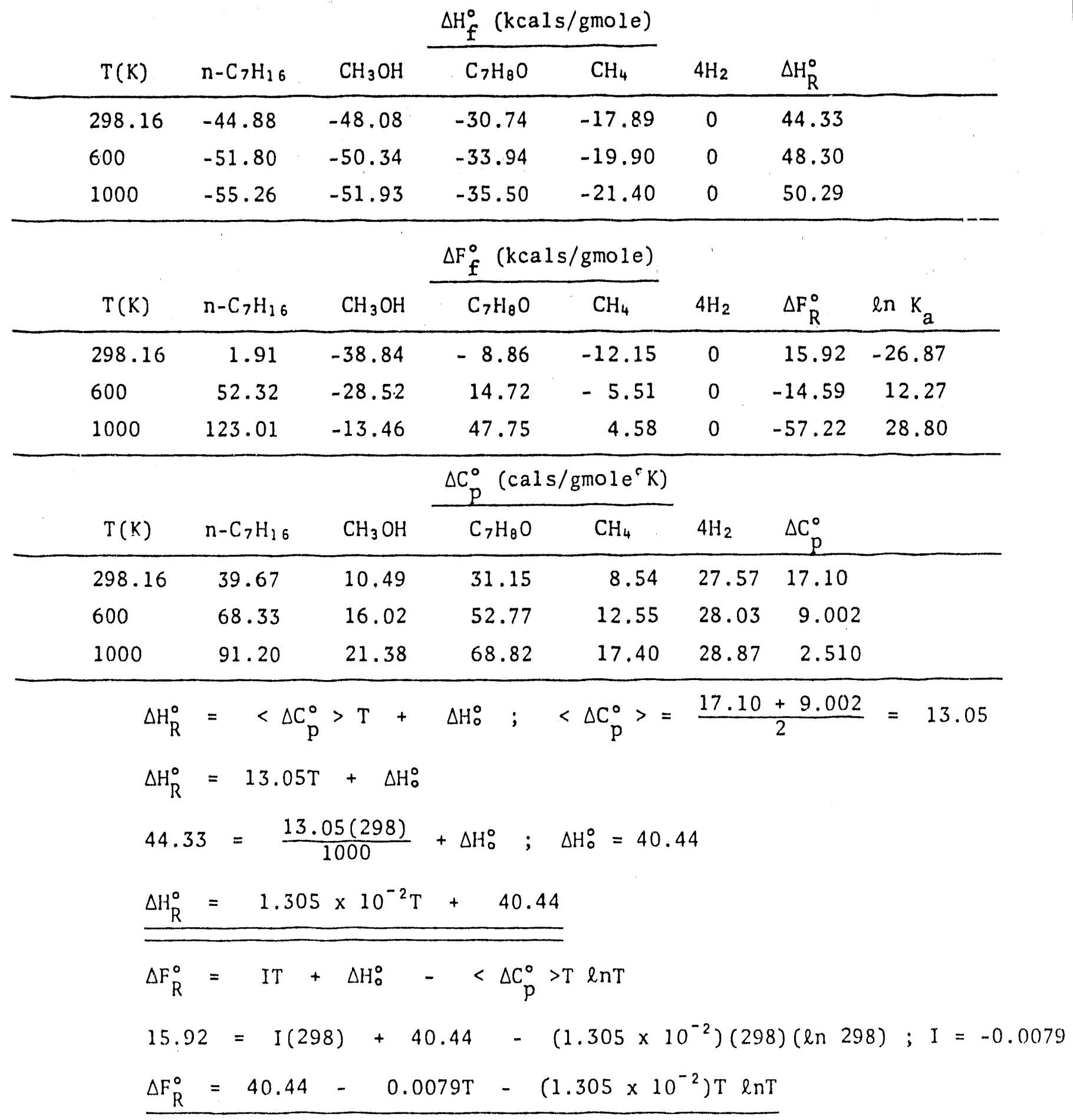


TABLE 8 - Dehydrocyclization and Simultaneous

Hydroxylation and Alkylation of n-Hexane to o-Cresol

1) $\mathrm{n}-\mathrm{C}_{6} \mathrm{H}_{14}+\mathrm{C}_{6} \mathrm{H}_{6}+4 \mathrm{H}_{2}$

2) $\mathrm{C}_{6} \mathrm{H}_{6}+\mathrm{CH}_{3} \mathrm{OH}+\mathrm{C}_{7} \mathrm{H}_{8} \mathrm{O}+\mathrm{H}_{2}$

Overa 11: $\quad \mathrm{n}-\mathrm{C}_{6} \mathrm{H}_{14}+\mathrm{CH}_{3} \mathrm{OH} \rightarrow \mathrm{H}_{4} \mathrm{C}_{6}{ }^{\prime}{ }_{\mathrm{OH}}^{\mathrm{CH}_{3}}+5 \mathrm{H}_{2}$

$\Delta H_{f}^{\circ}(\mathrm{kcals} / \mathrm{gmole})$

\begin{tabular}{|c|c|c|c|c|c|c|}
\hline$T(K)$ & $\mathrm{n}-\mathrm{C}_{6} \mathrm{H}_{14}$ & $\mathrm{CH}_{3} \mathrm{OH}$ & $\mathrm{C}_{7} \mathrm{H}_{8} \mathrm{O}$ & $5 \mathrm{H}_{2}$ & $\Delta \mathrm{H}_{\mathrm{R}}^{\circ}$ & \\
\hline 298.16 & -39.96 & -48.08 & -30.74 & 0 & 57.30 & \\
\hline 600 & -46.10 & -50.34 & -33.94 & 0 & 62.50 & \\
\hline 1000 & -49.25 & -51.93 & -35.50 & 0 & 65.68 & \\
\hline \multirow[b]{2}{*}{$T(K)$} & \multicolumn{6}{|c|}{$\Delta \mathrm{F}_{\mathrm{f}}^{\circ}(\mathrm{kcals} / \mathrm{gmole})$} \\
\hline & $\mathrm{n}-\mathrm{C}_{6} \mathrm{H}_{14}$ & $\mathrm{CH}_{3} \mathrm{OH}$ & $\mathrm{C}_{7} \mathrm{H}_{8} \mathrm{O}$ & $5 \mathrm{H}_{2}$ & $\Delta \mathrm{F}_{\mathrm{R}}^{\circ}$ & $\ln K_{a}$ \\
\hline 298.16 & -0.06 & -38.84 & -8.86 & 0 & 30.04 & -50.71 \\
\hline 600 & 43.02 & -28.52 & 14.72 & 0 & 0.220 & -0.1845 \\
\hline 1000 & 103.57 & -13.46 & 47.75 & 0 & -42.36 & 21.32 \\
\hline
\end{tabular}

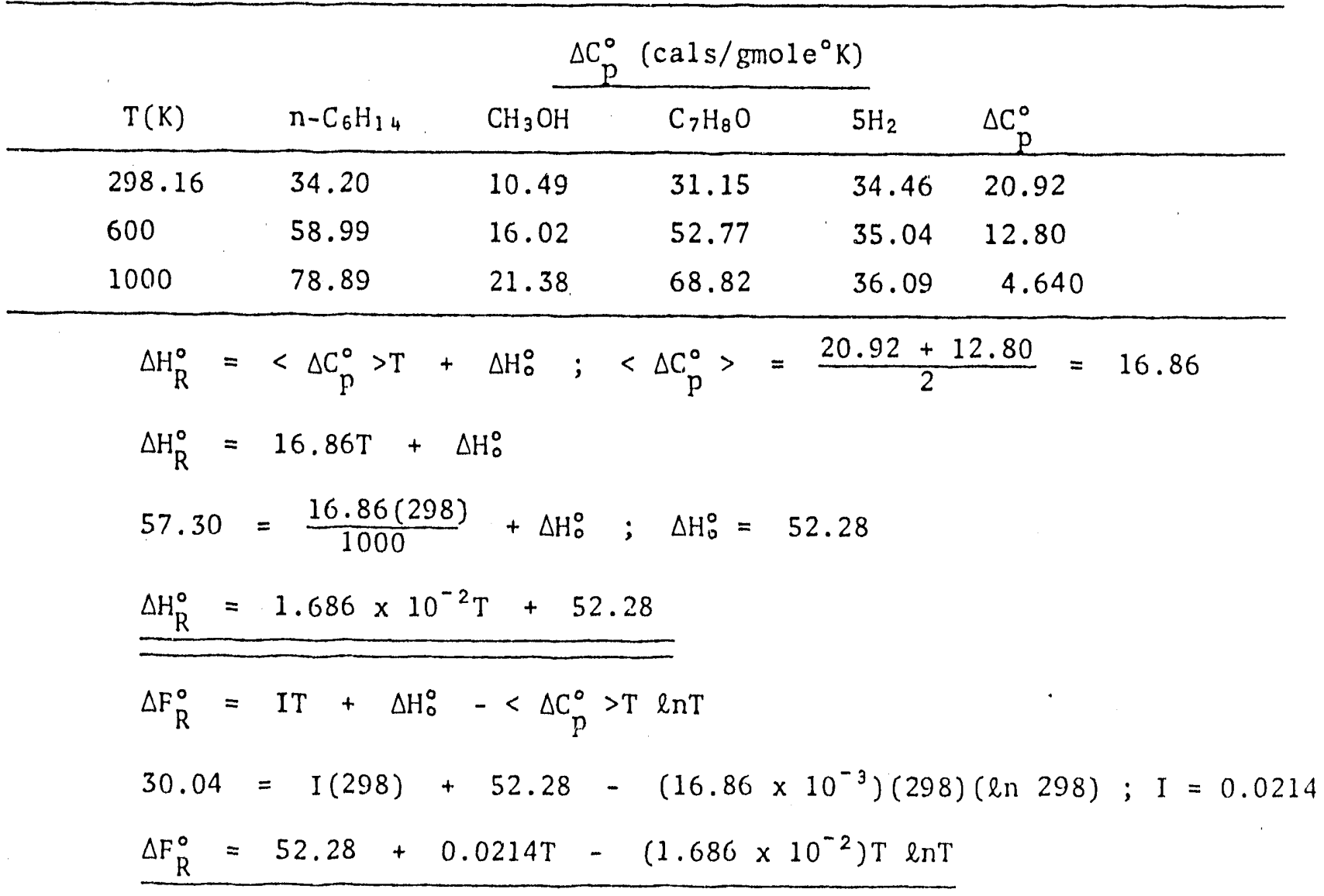


TABLE 9 - Alkylation of Benzene to Toluene

$$
\begin{gathered}
\mathrm{C}_{6} \mathrm{H}_{6}+\mathrm{CH}_{3} \mathrm{OH}+\mathrm{H}_{5} \mathrm{C}_{6}-\mathrm{CH}_{3}+\mathrm{H}_{2} \mathrm{O} \\
\Delta \mathrm{H}_{\mathrm{f}}^{\circ}(\mathrm{kcals} / \mathrm{gmole}) \\
\hline
\end{gathered}
$$

\begin{tabular}{|c|c|c|c|c|c|c|}
\hline \multirow{2}{*}{$\mathrm{T}(\mathrm{K})$} & \multirow[b]{2}{*}{$\mathrm{C}_{6} \mathrm{H}_{6}$} & \multicolumn{2}{|c|}{$\Delta \mathrm{F}_{\mathrm{f}}^{\circ}$ (kcals/gmole $)$} & \multirow[b]{2}{*}{$\mathrm{H}_{2} \mathrm{O}$} & \multirow[b]{2}{*}{$\Delta \mathrm{F}_{\mathrm{R}}^{\circ}$} & \multirow[b]{2}{*}{$\ln \mathrm{K}_{\mathrm{a}}$} \\
\hline & & $\mathrm{CH}_{3} \mathrm{OH}$ & $\mathrm{H}_{5} \mathrm{C}_{6}-\mathrm{CH}_{3}$ & & & \\
\hline 298.16 & 30.99 & -38.84 & 29.16 & -54.64 & -17.63 & 29.76 \\
\hline 600 & 43.66 & -28.52 & 48.32 & -51.16 & -17.98 & 15.08 \\
\hline \multirow[t]{2}{*}{1000} & 62.27 & -13.46 & 75.91 & -46.04 & -18.94 & 9.53 \\
\hline & \multicolumn{3}{|c|}{$\Delta \mathrm{C}_{\mathrm{p}}^{\circ}\left(\mathrm{cals} / \mathrm{gmole}^{\circ} \mathrm{K}\right)$} & & & \\
\hline $\mathrm{T}(\mathrm{K})$ & $\mathrm{C}_{6} \mathrm{H}_{6}$ & $\mathrm{CH}_{3} \mathrm{OH}$ & $\mathrm{H}_{5} \mathrm{C}_{6}-\mathrm{CH}_{3}$ & $\mathrm{H}_{2} \mathrm{O}$ & $\Delta \mathrm{C}_{\mathrm{p}}^{\circ}$ & \\
\hline 298.16 & 19.52 & 10.49 & 24.77 & 8.03 & 2.79 & \\
\hline 600 & 37.74 & 16.02 & 47.20 & 8.68 & 2.12 & \\
\hline 1000 & 50.16 & 21.38 & 63.32 & 9.85 & 1.63 & \\
\hline
\end{tabular}

\begin{tabular}{llllll}
$\mathrm{T}(\mathrm{K})$ & $\mathrm{C}_{6} \mathrm{H}_{6}$ & \multicolumn{1}{c}{$\mathrm{CH}_{3} \mathrm{OH}$} & $\mathrm{H}_{5} \mathrm{C}_{6}-\mathrm{CH}_{3}$ & \multicolumn{1}{c}{$\mathrm{H}_{2} \mathrm{O}$} & \multicolumn{1}{c}{$\Delta \mathrm{H}_{\mathrm{R}}^{\circ}$} \\
\hline 298.16 & 19.82 & -48.08 & 11.95 & -57.80 & -17.59 \\
600 & 16.71 & -50.34 & 8.02 & -58.50 & -16.85 \\
1000 & 14.82 & -51.93 & 6.01 & -59.24 & -16.12 \\
\hline
\end{tabular}

$$
\begin{aligned}
& \Delta \mathrm{H}_{\mathrm{R}}^{\circ}=\left\langle\Delta \mathrm{C}_{\mathrm{p}}^{\circ}\right\rangle \mathrm{T}+\mathrm{k} ;\left\langle\Delta \mathrm{C}_{\mathrm{p}}^{\circ}\right\rangle=\frac{2.79+2.12}{2}=2.455 \\
& \Delta \mathrm{H}_{\mathrm{R}}^{\circ}=2.455 \mathrm{~T}+\Delta \mathrm{H}_{0}^{\circ} \\
& -17.59=\frac{2.455(298)}{1000}+\Delta H_{\circ}^{\circ} ; \Delta H_{\circ}^{\circ}=-18.322 \\
& \Delta \mathrm{H}_{\mathrm{R}}^{\circ}=2.455 \times 10^{-3} \mathrm{~T}-18.322 \\
& \Delta \mathrm{F}_{\mathrm{R}}^{\circ}=\mathrm{IT}+\Delta \mathrm{H}_{0}^{\circ}-\left\langle\Delta \mathrm{C}_{\mathrm{p}}^{\circ}>\mathrm{T} \ln \mathrm{T}\right. \\
& -17.63=I(298)-18.322-\left(2.455 \times 10^{-3}\right)(298)(\ln 298) ; \quad I=0.0163 \\
& \Delta \mathrm{F}_{\mathrm{R}}^{\mathrm{o}}=-18.322+0.0163 \mathrm{~T}-\left(2.455 \times 10^{-3}\right) \mathrm{T} \ell \mathrm{nT} .
\end{aligned}
$$


TABLE 10 - Hydroxylation of Benzene to Phenol

$$
\begin{gathered}
\mathrm{C}_{6} \mathrm{H}_{6}+\mathrm{CH}_{3} \mathrm{OH} \rightarrow \mathrm{C}_{6} \mathrm{H}_{6} \mathrm{O}+\mathrm{CH}_{4} \\
\frac{\Delta \mathrm{H}_{f}^{\circ}(\mathrm{kcals} / \mathrm{gmole})}{}
\end{gathered}
$$

\begin{tabular}{|c|c|c|c|c|c|c|}
\hline$T(K)$ & $\mathrm{C}_{6} \mathrm{H}_{6}$ & $\mathrm{CH}_{3} \mathrm{OH}$ & $\mathrm{H}_{5} \mathrm{C}_{6}-\mathrm{OH}$ & $\mathrm{CH}_{4}$ & $\Delta \mathrm{H}_{\mathrm{R}}^{\circ}$ & \\
\hline 298.16 & 19.82 & -48.08 & -23.03 & -17.89 & -12.66 & \\
\hline 600 & 16.71 & -50.34 & -25.53 & -19.90 & -11.80 & \\
\hline 1000 & 14.82 & -51.93 & -26.80 & -21.40 & -11.09 & \\
\hline \multicolumn{7}{|c|}{$\Delta F_{f}^{0}(\mathrm{kcals} / \mathrm{gmole})$} \\
\hline$T(K)$ & $\mathrm{C}_{6} \mathrm{H}_{6}$ & $\mathrm{CH}_{3} \mathrm{OH}$ & $\mathrm{H}_{5} \mathrm{C}_{6}-\mathrm{OH}$ & $\mathrm{CH}_{4}$ & $\Delta_{\mathrm{R}}^{\circ}$ & $\ln K_{a}=\frac{R}{R T}$ \\
\hline 298.16 & 30.99 & -38.84 & -7.86 & -12.15 & -12.16 & 20.53 \\
\hline 600 & 43.66 & -28.52 & 8.62 & -5.51 & -12.03 & 10.09 \\
\hline 1000 & 62.27 & -13.46 & 31.84 & 4.58 & -12.39 & 6.24 \\
\hline \multicolumn{7}{|c|}{$\Delta C_{p}^{\circ}\left(\right.$ cals $\left./ g^{\prime}{ }^{\circ} e^{\circ} \mathrm{K}\right)$} \\
\hline$T(K)$ & $\mathrm{C}_{6} \mathrm{H}_{6}$ & $\mathrm{CH}_{3} \mathrm{OH}$ & $\mathrm{H}_{5} \mathrm{C}_{6}-\mathrm{OH}$ & $\mathrm{CH}_{4}$ & $\Delta C_{p}^{0}$ & \\
\hline 298.16 & 19.52 & 10.49 & 24.75 & 8.54 & 3.28 & \\
\hline 600 & 37.74 & 16.02 & 43.54 & 12.55 & 2.33 & \\
\hline 1000 & 50.16 & 21.38 & 55.49 & 17.40 & 1.35 & \\
\hline
\end{tabular}

$$
\begin{aligned}
\Delta H_{\mathrm{R}}^{\circ}= & \delta \Delta \mathrm{C}_{\mathrm{F}}^{\circ} \mathrm{dT}+\mathrm{k}=\left\langle\Delta \mathrm{C}_{\mathrm{p}}^{\circ}\right\rangle \mathrm{T}+\mathrm{k} \\
& \left\langle\Delta \mathrm{C}_{\mathrm{p}}^{\circ}\right\rangle=\frac{3.28+2.33}{2}=2.805
\end{aligned}
$$$$
-12.66=\frac{2.805(298.16)}{1000}+\Delta H_{0}^{\circ} ; \Delta H_{\circ}^{\circ}=-13.496
$$$$
\Delta H_{\mathrm{R}}^{\circ}=2.805 \times 10^{-3} \mathrm{~T}-13.496
$$

$$
\Delta \mathrm{F}_{\mathrm{R}}^{0}=\mathrm{IT}+\Delta \mathrm{H}_{0}^{\circ}-\left\langle\Delta \mathrm{C}_{\mathrm{p}}^{0}>\mathrm{T}\right. \text { \&nT }
$$

$-12.16=I(298)-13.496-\left(2.805 \times 10^{-3}\right)(298)(\ln 298) ; I=0.0205$

$$
\Delta \mathrm{F}_{\mathrm{R}}^{\circ}=-13.496+0.0205 \mathrm{~T}-2.805 \times 10^{-3} \mathrm{~T} \ell \mathrm{nT}
$$


TABLE 11 - Hydroxylation of Toluene to o-Cresol

$$
\mathrm{H}_{5} \mathrm{C}_{6}-\mathrm{CH}_{3}+\mathrm{CH}_{3} \mathrm{OH}+\mathrm{H}_{4} \mathrm{C}_{6}{ }_{\mathrm{OH}}^{\mathrm{CH}_{3}}+\mathrm{CH}_{4}
$$

$\Delta H_{f}^{\circ}(k c a l s / g m o l e)$

\begin{tabular}{llllll}
$\mathrm{T}(\mathrm{K})$ & $\mathrm{C}_{7} \mathrm{H}_{8}$ & $\mathrm{CH}_{3} \mathrm{OH}$ & $\mathrm{C}_{7} \mathrm{H}_{8} \mathrm{O}$ & \multicolumn{1}{c}{$\mathrm{CH}_{4}$} & $\Delta \mathrm{H}_{\mathrm{R}}^{\circ}$ \\
\hline 298.16 & 11.95 & -48.08 & -30.74 & -17.89 & -12.50 \\
600 & 8.02 & -50.34 & -33.94 & -19.90 & -11.52 \\
1000 & 6.01 & -51.93 & -35.50 & -21.40 & -10.98 \\
\hline
\end{tabular}

\begin{tabular}{|c|c|c|c|c|c|c|}
\hline \multirow[b]{2}{*}{$\mathrm{T}(\mathrm{K})$} & \multirow[b]{2}{*}{$\mathrm{C}_{7} \mathrm{H}_{8}$} & \multirow[b]{2}{*}{$\mathrm{CH}_{3} \mathrm{OH}$} & \multicolumn{2}{|c|}{$\Delta F_{f}^{\circ}(\mathrm{kcals} / \mathrm{gmole})$} & \multirow[b]{2}{*}{$\Delta \mathrm{F}_{\mathrm{R}}^{0}$} & \multirow[b]{2}{*}{$\ln K_{a}$} \\
\hline & & & $\mathrm{C}_{7} \mathrm{H}_{8} \mathrm{O}$ & $\mathrm{CH}_{4}$ & & \\
\hline 298.16 & 29.16 & -38.84 & -8.86 & -12.15 & -11.33 & 19.12 \\
\hline 6.00 & 48.32 & -28.52 & 14.72 & -5.51 & -10.59 & 8.88 \\
\hline \multirow[t]{2}{*}{1000} & 75.91 & -13.46 & 47.75 & 4.58 & -10.12 & 5.09 \\
\hline & & . & \multicolumn{2}{|c|}{$\Delta \mathrm{C}_{\mathrm{p}}^{\circ}\left(\mathrm{cals} / \mathrm{gmole}^{\circ} \mathrm{K}\right)$} & \multirow[b]{2}{*}{$\Delta \mathrm{C}_{\mathrm{p}}^{0}$} & \\
\hline$T(K)$ & $\mathrm{C}_{7} \mathrm{H}_{8}$ & $\mathrm{CH}_{3} \mathrm{OH}$ & $\mathrm{C}_{7} \mathrm{H}_{8} \mathrm{O}$ & $\mathrm{CH}_{4}$ & & \\
\hline 298.16 & 24.77 & 10.49 & 31.15 & 8.54 & 4.43 & \\
\hline 600 & 47.20 & 16.02 & 52.77 & 12.55 & 2.10 & \\
\hline 1000 & 63.32 & 21.38 & 68.82 & 17.40 & 1.52 & \\
\hline
\end{tabular}

$$
\begin{aligned}
& \Delta \mathrm{H}_{\mathrm{R}}^{\circ}=\left\langle\Delta \mathrm{C}_{\mathrm{p}}^{\circ}\right\rangle \mathrm{T}+\mathrm{H}_{\circ}^{\circ} ;\left\langle\Delta \mathrm{C}_{\mathrm{p}}^{\circ}\right\rangle=\frac{4.43+2.10}{2}=3.265 \\
& \Delta \mathrm{H}_{\mathrm{R}}^{\circ}=3.265 \mathrm{~T}+\Delta \mathrm{H}_{\circ}^{\circ} \\
& -12.50=\frac{3.265(298)}{1000}+\Delta \mathrm{H}_{\circ}^{\circ} ; \Delta \mathrm{H}_{\circ}^{\circ}=-13.473 \\
& \Delta \mathrm{H}_{\mathrm{R}}^{\circ}=3.265 \times 10^{-3} \mathrm{~T}-13.473
\end{aligned}
$$$$
\Delta \mathrm{F}_{\mathrm{R}}^{0}=\mathrm{IT}+\Delta \mathrm{H}_{0}^{\circ}-\left\langle\Delta \mathrm{C}_{\mathrm{p}}^{0}>\mathrm{T} \ln \mathrm{T}\right.
$$$$
-11.33=I(298)-13.473-\left(3.265 \times 10^{-3}\right)(298)(\ln 298) ; I=0.0258
$$$$
\Delta \mathrm{F}_{\mathrm{R}}^{0}=-13.473+0.0258 \mathrm{~T}-\left(3.265 \times 10^{-3}\right) \mathrm{T} \ln \mathrm{T}
$$ 
TABLE 12 - Simultaneous Alkylation and Hydroxylation of Benzene to o-Cresol

$$
\mathrm{C}_{6} \mathrm{H}_{6}+\mathrm{CH}_{3} \mathrm{OH} \rightarrow \mathrm{H}_{4} \mathrm{C}_{6}^{-}{ }_{\mathrm{OH}}^{\mathrm{CH}_{3}}+\mathrm{H}_{2}
$$

\begin{tabular}{lccccc} 
& & \multicolumn{3}{c}{$\Delta \mathrm{H}_{\mathrm{f}}^{\circ}(\mathrm{kcals} / \mathrm{gmole})$} \\
$\mathrm{T}(\mathrm{K})$ & $\mathrm{C}_{6} \mathrm{H}_{6}$ & $\mathrm{CH}_{3} \mathrm{OH}$ & $\mathrm{C}_{7} \mathrm{H}_{8} \mathrm{O}$ & $\mathrm{H}_{2}$ & $\Delta \mathrm{H}_{\mathrm{R}}^{\circ}$ \\
\hline 298.16 & 19.82 & -48.08 & -30.74 & 0 & -2.48 \\
600 & 16.71 & -50.34 & -33.94 & 0 & -0.31 \\
1000 & 14.82 & -51.93 & -35.50 & 0 & 1.61 \\
\hline
\end{tabular}

\begin{tabular}{|c|c|c|c|c|c|c|}
\hline \multirow[b]{2}{*}{$T(K)$} & \multirow[b]{2}{*}{$\mathrm{C}_{6} \mathrm{H}_{6}$} & \multirow[b]{2}{*}{$\mathrm{CH}_{3} \mathrm{OH}$} & \multicolumn{2}{|c|}{$\Delta F_{f}^{\circ}($ kcals/gmole $)$} & \multirow[b]{2}{*}{$\Delta \mathrm{F}_{\mathrm{R}}^{\circ}$} & \multirow[b]{2}{*}{$\ln \mathrm{K}_{\mathrm{a}}$} \\
\hline & & & $\mathrm{C}_{7} \mathrm{H}_{8} \mathrm{O}$ & $\mathrm{H}_{2}$ & & \\
\hline 298.16 & 30.99 & -38.84 & -8.86 & 0 & -1.01 & 1.70 \\
\hline 600 & 43.66 & -28.52 & 14.72 & 0 & -0.42 & 0.352 \\
\hline \multirow[t]{2}{*}{1000} & 62.27 & -13.46 & 47.75 & 0 & -1.06 & 0.534 \\
\hline & & & \multicolumn{2}{|c|}{$\Delta \mathrm{C}_{\mathrm{p}}^{\circ}\left(\mathrm{cals} / \mathrm{gmole}^{\circ} \mathrm{K}\right)$} & \multirow[b]{2}{*}{$\Delta \mathrm{C}_{\mathrm{p}}^{\circ}$} & \\
\hline$T(K)$ & $\mathrm{C}_{6} \mathrm{H}_{6}$ & $\mathrm{CH}_{3} \mathrm{OH}$ & $\mathrm{C}_{7} \mathrm{H}_{8} \mathrm{O}$ & $\mathrm{H}_{2}$ & & \\
\hline 298.16 & 19.52 & 10.49 & 31.15 & 6.892 & 8.032 & \\
\hline 600 & 37.74 & 16.02 & 52.77 & 7.008 & 6.018 & \\
\hline .1000 & 50.16 & 21.38 & 68.82 & 7.217 & 4.497 & \\
\hline
\end{tabular}

$\Delta \mathrm{H}_{\mathrm{R}}^{\circ}=\left\langle\Delta \mathrm{C}_{\mathrm{p}}^{\circ}\right\rangle \mathrm{T}+\Delta \mathrm{H}_{\circ}^{\circ} ;\left\langle\Delta \mathrm{C}_{\mathrm{p}}^{\circ}\right\rangle=\frac{8.032+6.018}{2}=7.025$

$\Delta \mathrm{H}_{\mathrm{R}}^{\circ}=7.025 \mathrm{~T}+\Delta \mathrm{H}_{0}^{\circ}$

$-2.48=\frac{7.025(298)}{1000}+\Delta \mathrm{H}_{\circ}^{\circ} ; \Delta \mathrm{H}_{\circ}^{\circ}=-4.5735$

$\Delta H_{\mathrm{R}}^{\circ}=7.025 \times 10^{-3} \mathrm{~T}-4.5735$

$\Delta \mathrm{F}_{\mathrm{R}}^{\circ}=\mathrm{IT}+\Delta \mathrm{H}_{0}^{\circ}-\left\langle\Delta \mathrm{C}_{\mathrm{p}}^{\circ}>\mathrm{T} \ln \mathrm{T}\right.$

$-1.01=I(298)-4.5735-\left(7.025 \times 10^{-3}\right)(298)(\ln 298) ; I=0.0520$

$\Delta \mathrm{F}_{\mathrm{R}}^{\circ}=-4.5735+0.0520 \mathrm{~T}-\left(7.025 \times 10^{-3}\right) \mathrm{T} \operatorname{lnT}$ 
TABLE 13 - Partial Oxidation of Toluene to Benzaldehyde $\mathrm{H}_{5} \mathrm{C}_{6}-\mathrm{CH}_{3}+\mathrm{O}_{2} \rightarrow \mathrm{H}_{5} \mathrm{C}_{6}-\mathrm{C}_{3 \mathrm{H}}^{\prime \prime}+\mathrm{H}_{2} \mathrm{O}$

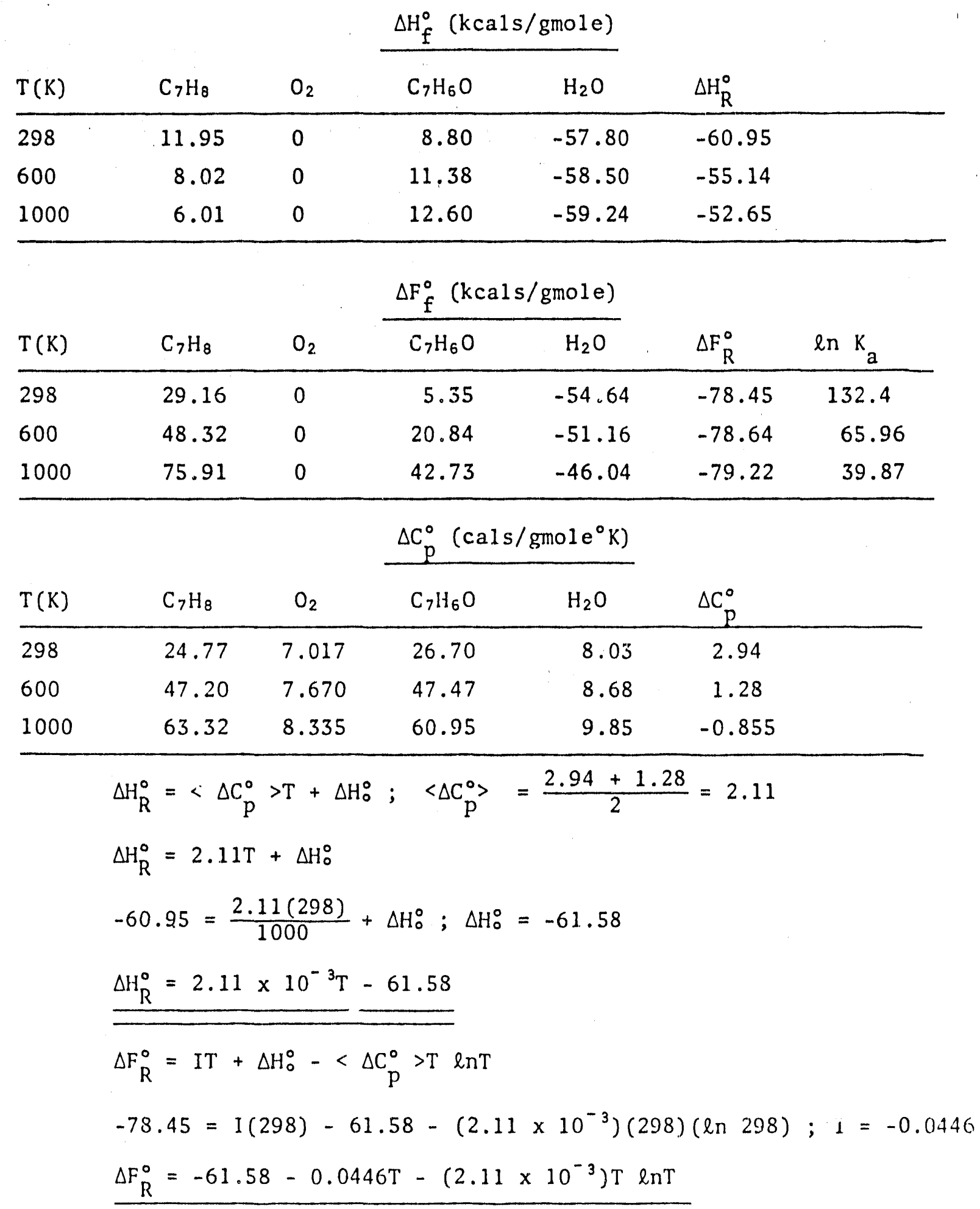


TABLE 14 - Oxidation of p-Xylene to Terephthalic Acid<smiles>Cc1ccc(C)cc1</smiles>

\begin{tabular}{|c|c|c|c|c|c|c|}
\hline \multirow[b]{2}{*}{$\mathrm{T}(\mathrm{K})$} & \multirow[b]{2}{*}{$\mathrm{C}_{8} \mathrm{H}_{10}$} & \multirow[b]{2}{*}{$2 \mathrm{O}_{2}$} & \multicolumn{2}{|c|}{$\Delta \mathrm{H}_{\mathrm{f}}^{\circ}(\mathrm{kcals} / \mathrm{gmole})$} & \multirow[b]{2}{*}{$\Delta \mathrm{H}_{\mathrm{R}}^{\circ}$} & \\
\hline & & & $\mathrm{C}_{8} \mathrm{H}_{6} \mathrm{O}_{4}$ & $2 \mathrm{H}_{2}$ & & \\
\hline 298 & 4.29 & 0 & -195.1 & 0 & -199.4 & \\
\hline 500 & 0.68 & 0 & -195.7 & 0 & -186.7 & \\
\hline \multirow[t]{2}{*}{1000} & -3.61 & 0 & -204.9 & 0 & -159.4 & \\
\hline & & & \multicolumn{2}{|c|}{$\left(F_{f}^{\circ}(\mathrm{kcals} / \mathrm{gmole})\right.$} & & \\
\hline$T(K)$ & $\mathrm{C}_{8} \mathrm{H}_{10} \mathrm{O}$ & $2 \mathrm{O}_{2}$ & $\mathrm{C}_{8} \mathrm{H}_{6} \mathrm{O}_{4}$ & $2 \mathrm{H}_{2}$ & $\Delta \mathrm{F}_{\mathrm{R}}^{\circ}$ & $\ln \mathrm{K}_{\mathrm{a}}$ \\
\hline 298 & 28.95 & 0 & -149.6 & 0 & -178.5 & 301.5 \\
\hline 500 & 46.73 & 0 & -116.1 & 0 & -162.8 & 163.8 \\
\hline \multirow[t]{2}{*}{1000} & 94.90 & 0 & -26.8 & 0 & -121.7 & 61.2 \\
\hline & & & \multicolumn{2}{|c|}{$\Delta \mathrm{C}_{\mathrm{p}}^{\circ}(\mathrm{cals} / \mathrm{gmole} \mathrm{K})$} & & \\
\hline $\mathrm{T}(\mathrm{K})$ & $\mathrm{C}_{8} \mathrm{H}_{10}$ & $2 \mathrm{O}_{2}$ & $\mathrm{C}_{8} \mathrm{H}_{6} \mathrm{O}_{4}$ & $2 \mathrm{H}_{2}$ & $\Delta \mathrm{C}_{\mathrm{p}}^{\circ}$ & \\
\hline 298 & 30.32 & 14.03 & 26.91 & 13.78 & -3.66 & \\
\hline 500 & 48.06 & 14.86 & 44.74 & 13.99 & -4.19 & \\
\hline 1000 & 74.02 & 16.67 & 69.36 & 14.43 & -6.90 & \\
\hline
\end{tabular}

$$
\begin{aligned}
& \Delta \mathrm{H}_{\mathrm{R}}^{\circ}=\left\langle\Delta \mathrm{C}_{\mathrm{p}}^{\circ}\right\rangle \mathrm{T}+\Delta \mathrm{H}_{\circ}^{\circ} ;\left\langle\Delta \mathrm{C}_{\mathrm{p}}^{\circ}\right\rangle:=\frac{-3.66-4.19}{2}=-3.93 \\
& \Delta \mathrm{H}_{\mathrm{R}}^{\circ}=-3.93 \mathrm{~T}+\Delta \mathrm{H}_{\circ}^{\circ} \\
& -199.4=\frac{-3.93(298)}{1000}+\Delta H_{0}^{\circ} ; \Delta H_{0}^{\circ}=-198.2 \\
& \Delta H_{R}^{\circ}=-3.93 \times 10^{-3} \mathrm{~T}-198.2 \\
& \Delta \mathrm{F}_{\mathrm{R}}^{\circ}=\mathrm{IT}+\Delta \mathrm{H}_{0}^{\circ}-\left\langle\Delta \mathrm{C}_{\mathrm{P}}^{\circ}>\mathrm{T} \ln \mathrm{T}\right. \\
& -178.5=3(298)-198.2-\left(-3.93 \times 10^{-3}\right)(298)(\ln 298) ; I=0.0437 \\
& \Delta \mathrm{F}_{\mathrm{R}}^{\circ}=-108.2+0.0437 \mathrm{~T}+\left(3.93 \times 10^{-3}\right) \mathrm{T} \ln \mathrm{T}
\end{aligned}
$$


TABLE 15 - Carboxylation of Phenol to Salicylic Acid

$$
\mathrm{H}_{5} \mathrm{C}_{6}-\mathrm{OH}+\mathrm{CO}_{2} \rightarrow \mathrm{H}_{4} \mathrm{C}_{6}-{ }_{\mathrm{OH}}^{\mathrm{COOH}}
$$

\begin{tabular}{|c|c|c|c|c|c|}
\hline \multirow[b]{2}{*}{$\mathrm{T}(\mathrm{K})$} & \multirow[b]{2}{*}{$\mathrm{C}_{6} \mathrm{H}_{6} \mathrm{O}$} & \multicolumn{2}{|c|}{$\Delta \mathrm{H}_{\mathrm{f}}^{\circ}(\mathrm{kcals} / \mathrm{gmole})$} & \multirow[b]{2}{*}{$\Delta \mathrm{H}_{\mathrm{R}}^{\circ}$} & \\
\hline & & $\mathrm{CO}_{2}$ & $\mathrm{C}_{7} \mathrm{H}_{6} \mathrm{O}_{3}$ & & \\
\hline 298 & -23.03 & -94.05 & -139.9 & -22.37 & \multirow{3}{*}{1} \\
\hline 500 & -24.90 & -94.09 & -142.8 & -23.81 & \\
\hline 1000 & -26.80 & -94.32 & -145.1 & -23.98 & \\
\hline \multirow[b]{2}{*}{$\mathrm{T}(\mathrm{K})$} & & \multicolumn{2}{|c|}{$\Delta \mathrm{F}_{\mathrm{f}}^{\circ}(\mathrm{kcal} \mathrm{s} / \mathrm{gmole})$} & \multirow[b]{2}{*}{$\Delta \mathrm{F}_{\mathrm{R}}^{\circ}$} & \multirow[b]{2}{*}{$\ln \mathrm{K}_{\mathrm{a}}$} \\
\hline & $\mathrm{C}_{6} \mathrm{H}_{6} \mathrm{O}$ & $\mathrm{CO}_{2}$ & $\mathrm{C}_{7} \mathrm{H}_{6} \mathrm{O}_{3}$ & & \\
\hline 298 & -7.86 & -94.26 & -99.93 & 2.19 & -3.70 \\
\hline 500 & 2.99 & -94.39 & -72.21 & 19.19 & -19.32 \\
\hline \multirow[t]{2}{*}{1000} & 31.84 & -94.61 & -4.69 & 121.76 & -61.28 \\
\hline & & \multicolumn{2}{|c|}{$\Delta C_{\mathrm{p}}^{\circ}\left(\mathrm{Cals}^{\left.\mathrm{s} / \mathrm{gmole} \mathrm{e}^{\circ} \mathrm{K}\right)}\right.$} & \multirow[b]{2}{*}{$\Delta \mathrm{C}_{\mathrm{p}}^{\circ}$} & \\
\hline$T(K)$ & $\mathrm{C}_{6} \mathrm{H}_{6} \mathrm{O}$ & $\mathrm{CO}_{2}$ & $\mathrm{C}_{7} \mathrm{H}_{6} \mathrm{O}_{3}$ & & \\
\hline 298 & 24.75 & 8.87 & 24.22 & -9.40 & \\
\hline 500 & 38.64 & 10.66 & 40.77 & -8.53 & \\
\hline 1000 & 55.49 & 12.97 & 62.20 & -6.26 & \\
\hline
\end{tabular}

$\Delta \mathrm{H}_{\mathrm{R}}^{\circ}=\left\langle\Delta \mathrm{C}_{\mathrm{p}}^{\circ}\right\rangle \mathrm{T}+\Delta \mathrm{H}_{0}^{\circ} ;\left\langle\Delta \mathrm{C}_{\mathrm{p}}^{\circ}\right\rangle=\frac{-9.40-8.53}{2}=-8.97$

$\Delta H_{R}^{\circ}=-8.97 \mathrm{~T}+\Delta H_{0}^{\circ}$

$-22.37=\frac{-8.97(298)}{1000}+\Delta H_{0}^{\circ} ; \Delta H_{0}^{\circ}=-19.70$

$\Delta H_{R}^{\circ}=-8.97 \times 10^{-3} \mathrm{~T}-19.70$

$\Delta \mathrm{F}_{\mathrm{R}}^{\circ}=\mathrm{IT}+\Delta \mathrm{H}_{0}^{\circ}-<\Delta \mathrm{C}_{\mathrm{p}}^{\circ}>\mathrm{T} \ln \mathrm{T}$

$2.19=I(298)-19.70+\left(8.97 \times 10^{-3}\right)(298)(\ln 298) ; I=0.0224$

$\Delta \mathrm{F}_{\mathrm{R}}^{\circ}=-19.70+0.0224 \mathrm{~T}+\left(8.97 \times 10^{-3}\right) \mathrm{T} \ln \mathrm{T}$ 
TABLE 16 - Oxidation of Benzene to Maleic Anhydride

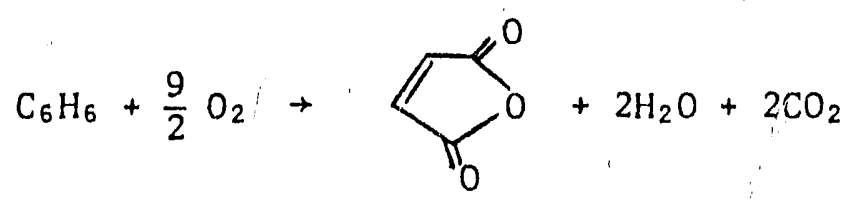

\begin{tabular}{|c|c|c|c|c|c|c|c|}
\hline \multirow[b]{2}{*}{$\mathrm{T}(\mathrm{K})$} & \multirow[b]{2}{*}{$\mathrm{C}_{6} \mathrm{H}_{6}$} & \multirow[b]{2}{*}{$\frac{9}{2} \mathrm{O}_{2}$} & \multicolumn{2}{|c|}{$\Delta \mathrm{H}_{\mathrm{f}}^{\circ}(\mathrm{kcals} / \mathrm{gmole})$} & \multirow[b]{2}{*}{$2 \mathrm{CO}_{2}$} & \multirow[b]{2}{*}{$\Delta \mathrm{H}_{\mathrm{R}}^{\circ}$} & \\
\hline & & & $\mathrm{C}_{4} \mathrm{H}_{2} \mathrm{O}_{3}$ & $2 \mathrm{H}_{2} \mathrm{O}$ & & & \\
\hline 298 & 19.82 & 0 & -112.4 & $2(-57.80)$ & $2(-94.05)$ & -435.9 & \\
\hline 600 & 16.71 & 0 & -121.0 & $2(-58.50)$ & $2(-94.12)$ & -443.0 & \\
\hline \multirow[t]{2}{*}{1000} & 14.82 & 0 & -132.4 & $2(-59.24)$ & $2(-94.32)$ & -454.3 & \\
\hline & \multirow[b]{2}{*}{$\mathrm{C}_{6} \mathrm{H}_{6}$} & \multirow[b]{2}{*}{$\frac{9}{2} \mathrm{O}_{2}$} & \multicolumn{2}{|c|}{$\Delta \mathrm{F}_{\mathrm{f}}^{\circ}(\mathrm{kcals} / \mathrm{gmole})$} & & \multirow[b]{2}{*}{$\Delta \mathrm{F}_{\mathrm{R}}^{\circ}$} & \multirow[b]{2}{*}{$\ln \mathrm{K}_{\mathrm{a}}$} \\
\hline $\mathrm{T}(\mathrm{K})$ & & & $\mathrm{C}_{4} \mathrm{H}_{2} \mathrm{O}_{3}$ & $2 \mathrm{H}_{2} \mathrm{O}$ & $2 \mathrm{CO}_{2}$ & & \\
\hline 298 & 30.99 & 0 & -115.3 & $2(-54.64)$ & $2(-94.26)$ & -444.1 & 750.0 \\
\hline 600 & 43.66 & 0 & -135.3 & $2(-51.16)$ & $2(-94.45)$ & -470.2 & 394.4 \\
\hline 1000 & 62.27 & 0 & -161.9 & $2(-46.04)$ & $2(-94.61)$ & -505.5 & 254.4 \\
\hline
\end{tabular}

\begin{tabular}{lcccccc}
\multicolumn{7}{c}{$\Delta \mathrm{C}_{\mathrm{p}}^{\circ}\left(\mathrm{cals} / \mathrm{gmole}^{\circ} \mathrm{K}\right)$} \\
$\mathrm{T}(\mathrm{K})$ & $\mathrm{C}_{6} \mathrm{H}_{6}$ & $\frac{9}{2} \mathrm{O}_{2}$ & $\mathrm{C}_{4} \mathrm{H}_{2} \mathrm{O}_{3}$ & $2 \mathrm{H}_{2} \mathrm{O}$ & $2 \mathrm{CO}_{2}$ & $\Delta \mathrm{C}_{\mathrm{p}}^{\circ}$ \\
\hline 298 & 19.52 & $\frac{9}{2}(7.017)$ & 17.35 & $2(8.03)$ & $2(8.87)$ & 0.0535 \\
600 & 37.74 & $"(7.670)$ & 30.53 & $2(8.68)$ & $2(11.31)$ & -1.745 \\
1000 & 50.16 & $"(8.335)$ & 39.49 & $2(9.85)$ & $2(12.97)$ & -2.538 \\
\hline
\end{tabular}

$\Delta \mathrm{H}_{\mathrm{R}}^{\circ}=\left\langle\Delta \mathrm{C}_{\mathrm{p}}^{\circ}\right\rangle \mathrm{T}+\Delta \mathrm{H}_{\circ}^{\circ} ;\left\langle\Delta \mathrm{C}_{\mathrm{p}}^{\circ}\right\rangle=\frac{0.0535-1.745}{2}=-0.8458$

$\Delta \mathrm{H}_{\mathrm{R}}^{\circ}=-0.8458 \mathrm{~T}+\Delta \mathrm{H}_{0}^{\circ}$

$-435.9=\frac{-0.8458(298)}{1000}+\Delta H_{\circ}^{\circ} ; \Delta H_{\circ}^{\circ}=-435.6$

$\Delta H_{R}^{\circ}=-3.458 \times 10^{-4} \mathrm{~T}-435.6$

$\Delta \mathrm{F}_{\mathrm{R}}^{\circ}=\mathrm{IT}+\Delta \mathrm{H}_{0}^{\circ}-\left\langle\Delta \mathrm{C}_{\mathrm{p}}^{\circ}>\mathrm{T} \operatorname{lnT}\right.$

$-444.1=I(298)-435.6-\left(-8.458 \times 10^{-4}\right)(298)(\ln 298) ; I=-0.033 .5$

$\mathrm{A}_{\mathrm{i}}^{\mathrm{n}}=-435.6-0.0333 \mathrm{~T}+\left(8.458 \times 10^{-4}\right) \mathrm{T} \operatorname{lnT}$ 
TABLE 17 - Direct Oxidation of Ethylene to Form Acetaldehyde

$$
\mathrm{C}_{2} \mathrm{H}_{4}+\frac{1}{2} \mathrm{O}_{2} \rightarrow \mathrm{CH}_{3} \mathrm{CHO}
$$

\begin{tabular}{|c|c|c|c|c|c|}
\hline \multirow[b]{2}{*}{$\mathrm{T}(\mathrm{K})$} & \multirow[b]{2}{*}{$\mathrm{C}_{2} \mathrm{H}_{4}$} & \multicolumn{2}{|c|}{$\Delta H_{f}^{\circ}($ kcals/gmole $)$} & \multirow[b]{2}{*}{$\Delta \mathrm{H}_{\mathrm{R}}^{\circ}$} & \\
\hline & & $\frac{1}{2} \mathrm{O}_{2}$ & $\mathrm{CH}_{3} \mathrm{CHO}$ & & \\
\hline 298 & 12.50 & 0 & -39.76 & -52.26 & \\
\hline 600 & 10.60 & 0 & -41.86 & -52.46 & \\
\hline \multirow[t]{2}{*}{1000} & 9.21 & 0 & -43.27 & -52.48 & \\
\hline & & \multicolumn{2}{|c|}{$\Delta \mathrm{F}_{\mathrm{f}}^{\circ}(\mathrm{kcals} / \mathrm{gmole})$} & & \\
\hline$T(K)$ & $\mathrm{C}_{2} \mathrm{H}_{4}$ & $\frac{1}{2} \mathrm{O}_{2}$ & $\mathrm{CH}_{3} \mathrm{CHO}$ & $\Delta \mathrm{F}_{\mathrm{R}}^{\circ}$ & $\ln \mathrm{K}_{\mathrm{a}}$ \\
\hline 298 & 16.28 & 0 & -31.86 & -48.14 & 81.30 \\
\hline 600 & 20.92 & 0 & -22.97 & -43.89 & 36.81 \\
\hline \multirow[t]{2}{*}{1000} & 28.25 & 0 & -9.91 & -38.16 & 19.20 \\
\hline & & \multicolumn{2}{|c|}{$\Delta \mathrm{C}_{\mathrm{p}}^{\circ}\left(\mathrm{cals} / \mathrm{gmole}^{\circ} \mathrm{K}\right)$} & & \\
\hline $\mathrm{T}(\mathrm{K})$ & $\mathrm{C}_{2} \mathrm{H}_{4}$ & $\frac{1}{2} \mathrm{O}_{2}$ & $\mathrm{CH}_{3} \mathrm{CHO}$ & $\Delta \mathrm{C}_{\mathrm{p}}^{\circ}$ & \\
\hline 298 & 10.41 & 3.508 & 13.06 & -0.8580 & \\
\hline 600 & 17.10 & 3.835 & 20.52 & -0.4150 & \\
\hline 1000 & 22.57 & 4.168 & 26.96 & 0.2220 & \\
\hline
\end{tabular}

$\Delta \mathrm{H}_{\mathrm{R}}^{\circ}=\left\langle\Delta \mathrm{C}_{\mathrm{p}}^{\circ}\right\rangle \mathrm{T}+\Delta \mathrm{H}_{\circ}^{\circ} ;\left\langle\Delta \mathrm{C}_{\mathrm{p}}^{\circ}\right\rangle=\frac{-0.8580-0.4150}{2}=-0.6365$

$-52.26=\frac{-0.6365(298)}{1000}+\Delta H_{\circ}^{\circ} ; \Delta H_{\circ}^{\circ}=-52.07$

$\Delta H_{R}^{\circ}=-6.365 \times 10^{-4} \mathrm{~T}-52.07$

$\Delta \mathrm{F}_{\mathrm{R}}^{\circ}=\mathrm{IT}+\Delta \mathrm{H}_{\circ}^{\circ}-\left\langle\Delta \mathrm{C}_{\mathrm{p}}^{\circ}>\mathrm{T} \operatorname{lnT}\right.$

$-48.14=I(298)-52.07+\left(6.365 \times 10^{-4}\right)(298)(\ln 298) ; I=0.009562$

$\Delta \mathrm{F}_{\mathrm{R}}^{\circ}=-52.07+0.009562 \mathrm{~T}+\left(6.365 \times 10^{-4}\right) \mathrm{T} \ln \mathrm{T}$ 
TABLE 18 - Oxidation of Ethylene to Form Ethylene Oxide

\begin{tabular}{|c|c|c|c|c|c|}
\hline \multirow[b]{2}{*}{$\mathrm{T}(\mathrm{K})$} & \multirow[b]{2}{*}{$\mathrm{C}_{2} \mathrm{H}_{4}$} & \multicolumn{2}{|c|}{$\Delta \mathrm{H}_{\mathrm{f}}^{\circ}(\mathrm{kcals} / \mathrm{gmole})$} & \multirow[b]{2}{*}{$\Delta \mathrm{H}_{\mathrm{R}}^{\circ}$} & \\
\hline & & $\frac{1}{2} \mathrm{O}_{2}$ & $\mathrm{C}_{2} \mathrm{H}_{4} \mathrm{O}$ & & \\
\hline 298 & 12.50 & 0 & -12.58 & -25.08 & \\
\hline 600 & 10.60 & 0 & -14.85 & -25.45 & \\
\hline \multirow[t]{2}{*}{1000} & 9.21 & 0 & -16.12 & -25.33 & \\
\hline & " & \multicolumn{2}{|c|}{$\Delta \mathrm{F}_{\mathrm{f}}^{\circ}(\mathrm{kcals} / \mathrm{gmole})$} & & \\
\hline$T(K)$ & $\mathrm{C}_{2} \mathrm{H}_{4}$ & $\frac{1}{2} \mathrm{O}_{2}$ & $\mathrm{C}_{2} \mathrm{H}_{4} \mathrm{O}$ & $\Delta \mathrm{F}_{\mathrm{R}}^{0}$ & $\ln \mathrm{K}_{\mathrm{a}}$ \\
\hline 298 & 16.28 & 0 & -3.13 & -19.41 & 32.78 \\
\hline 600 & 20.92 & 0 & 7.44 & -13.48 & 11.31 \\
\hline \multirow[t]{2}{*}{1000} & 28.25 & 0 & 22.74 & -5.51 & 2.773 \\
\hline & & \multicolumn{2}{|c|}{$\Delta \mathrm{C}_{\mathrm{p}}^{\circ}\left(\mathrm{cals} / \mathrm{gmole}^{\circ} \mathrm{K}\right)$} & & \\
\hline$T(K)$ & $\mathrm{C}_{2} \mathrm{H}_{4}$ & $\frac{1}{2} \mathrm{O}_{2}$ & $\mathrm{C}_{2} \mathrm{H}_{4} \mathrm{O}$ & $\Delta C_{p}^{\circ}$ & \\
\hline 298 & 10.41 & 3.508 & 11.54 & -2.378 & \\
\hline 600 & 17.10 & 3.835 & 20.62 & -0.3150 & \\
\hline 1000 & 22.57 & 4.168 & 27.47 & 0.7320 & \\
\hline
\end{tabular}

$$
\begin{aligned}
& \Delta \mathrm{H}_{\mathrm{R}}^{\circ}=\left\langle\Delta \mathrm{C}_{\mathrm{p}}^{\circ}\right\rangle \mathrm{T}+\Delta \mathrm{H}_{0}^{\circ} ;\left\langle\Delta \mathrm{C}_{\mathrm{p}}^{\circ}\right\rangle=\frac{-2.378-0.3150}{2}=-1.3465 \\
& -25.08=\frac{-1.3465(298)}{1000}+\Delta \mathrm{H}_{0}^{\circ} ; \Delta \mathrm{H}_{0}^{\circ}=-24.68 \\
& \frac{\Delta \mathrm{H}_{\mathrm{R}}^{\circ}=-1.3465 \times 10^{-3} \mathrm{~T}-24.68}{\Delta \mathrm{F}_{\mathrm{R}}^{\circ}=\mathrm{IT}+\Delta \mathrm{H}_{0}^{\circ}-\left\langle\Delta \mathrm{C}_{\mathrm{p}}^{\circ}\right\rangle \mathrm{T} \operatorname{lnT}} \\
& -19.41=\mathrm{I}(298)-24.68+\left(1.3465 \times 10^{-3}\right)(298)(\ln 298) ; \mathrm{I}=0.0100 \\
& \Delta \mathrm{F}_{\mathrm{R}}^{\circ}=-24.68+0.0100 \mathrm{~T}+\left(1.3465 \times 10^{-3}\right) \mathrm{T} \operatorname{lnT}
\end{aligned}
$$


TABLE 19 - Direct Oxidation of Propylene to Propylere Oxide

$\mathrm{CH}_{2}=\mathrm{CHCH}_{3}+\frac{1}{2} \mathrm{O}_{2}+\mathrm{CH}_{3} \mathrm{CHCH}_{2}$

\begin{tabular}{|c|c|c|c|c|c|}
\hline \multirow[b]{2}{*}{$T(K)$} & \multirow[b]{2}{*}{$\mathrm{C}_{3} \mathrm{H}_{6}$} & $\Delta \mathrm{H}_{\mathrm{f}}^{\circ}(\mathrm{kcal} / \mathrm{gmole})$ & \multirow[b]{2}{*}{$\mathrm{C}_{3} \mathrm{H}_{6} \mathrm{O}$} & \multirow[b]{2}{*}{$\Delta \mathrm{H}_{\mathrm{R}}^{\circ}$} & \\
\hline & & $\frac{1}{2} \mathrm{O}_{2}$ & & & \\
\hline 298 & 4.88 & 0 & -22.17 & -27.05 & \\
\hline 600 & 1.98 & 0 & -25.15 & -27.13 & \\
\hline \multirow[t]{2}{*}{1000} & 0.04 & 0 & -26.72 & -26.76 & \\
\hline & \multirow[b]{2}{*}{$\mathrm{C}_{3} \mathrm{H}_{6}$} & $\Delta F_{f}^{\circ}(\mathrm{kcal} / \mathrm{gmole})$ & \multirow[b]{2}{*}{$\mathrm{C}_{3} \mathrm{H}_{6} \mathrm{O}$} & \multirow[b]{2}{*}{$\Delta \mathrm{F}_{\mathrm{R}}^{\circ}$} & \multirow[b]{2}{*}{$\ln K_{a}$} \\
\hline$T(K)$ & & $\frac{1}{2} \mathrm{O}_{2}$ & & & \\
\hline 298 & 14.99 & 0 & -6.16 & -21.15 & 35.72 \\
\hline 600 & 26.46 & 0 & 11.36 & -15.10 & 12.67 \\
\hline 1000 & 43.43 & 0 & 36.26 & -7.17 & 3.608 \\
\hline \multirow[b]{2}{*}{$T(K)$} & \multicolumn{2}{|r|}{$\Delta C_{\mathrm{p}}^{\circ}\left(\mathrm{cal} / \mathrm{gmole}^{\circ} \mathrm{K}\right)$} & & \multirow[b]{2}{*}{$\Delta C_{p}^{0}$} & \\
\hline & $\mathrm{C}_{3} \mathrm{H}_{6}$ & $\frac{1}{2} \mathrm{O}_{2}$ & $\mathrm{C}_{3} \mathrm{H}_{6} \mathrm{O}$ & & \\
\hline 298 & 15.27 & 3.508 & 17.29 & -1.488 & \\
\hline 600 & 25.70 & 3.835 & 30.07 & 0.535 & \\
\hline 1000 & 34.46 & 4.168 & 39.79 & 1.162 & \\
\hline
\end{tabular}

$\Delta H_{\mathrm{R}}^{\circ}=\left\langle\Delta \mathrm{C}_{\mathrm{p}}^{\circ}\right\rangle \mathrm{T}+\Delta \mathrm{H}_{\circ}^{\circ} ;\left\langle\Delta \mathrm{C}_{\mathrm{p}}^{\circ}\right\rangle=\frac{-1.488+0.535}{2}=-0.4765$

$-27.05=\frac{-0.4765(298)}{1000}+\Delta H_{\circ}^{\circ} ; \Delta H_{\circ}^{\circ}=-26.91$

$\Delta H_{R}^{\circ}=-4.765 \times 10^{-4} \mathrm{~T}-26.91$

$\Delta \mathrm{F}_{\mathrm{R}}^{\circ}=\mathrm{IT}+\Delta \mathrm{H}_{0}^{\circ}-\left\langle\Delta \mathrm{C}_{\mathrm{p}}^{\circ}>\mathrm{T} \ln \mathrm{T}\right.$

$-21.15=I(298)-26.91+\left(4.765 \times 10^{-4}\right)(298)(\ln 298) ; I=0.0166$

$\Delta F_{R}^{0}=-26.91+0.0166 \mathrm{~T}+\left(4.765 \times 10^{-4}\right) \mathrm{T} \ln \mathrm{T}$ 
TABLE 20 - Catalytic Vapor Phase Oxidation of Propylene to Acrolein

$$
\mathrm{CH}_{2}=\mathrm{CHCH}_{3}+\mathrm{O}_{2}+\mathrm{CH}_{2}=\mathrm{CH}-\mathrm{CHO}+\mathrm{H}_{2} \mathrm{O}
$$

\begin{tabular}{|c|c|c|c|c|c|c|}
\hline \multirow[b]{2}{*}{$\mathrm{T}(\mathrm{K})$} & \multirow[b]{2}{*}{$\mathrm{C}_{3} \mathrm{H}_{6}$} & \multicolumn{2}{|c|}{$\Delta \mathrm{H}_{\mathrm{f}}^{\circ}(\mathrm{kcals} / \mathrm{gmole})$} & \multirow[b]{2}{*}{$\mathrm{H}_{2} \mathrm{O}$} & \multirow[b]{2}{*}{$\Delta \mathrm{H}_{\mathrm{R}}^{\circ}$} & \\
\hline & & $\mathrm{O}_{2}$ & $\mathrm{C}_{3} \mathrm{H}_{4} \mathrm{O}$ & & & \\
\hline 298 & 4.88 & 0 & -17.79 & -57.80 & -80.47 & \\
\hline 600 & 1.98 & 0 & -19.57 & -58.50 & -80.05 & \\
\hline \multirow{2}{*}{1000} & 0.04 & 0 & -20.54 & -59.24 & -79.82 & \\
\hline & \multirow[b]{2}{*}{$\mathrm{C}_{3} \mathrm{H}_{6}$} & \multirow[b]{2}{*}{$\mathrm{O}_{2}$} & cals/gme & \multirow[b]{2}{*}{$\mathrm{H}_{2} \mathrm{O}$} & \multirow[b]{2}{*}{$\Delta \mathrm{F}_{\mathrm{R}}^{\circ}$} & \multirow[b]{2}{*}{$\ln K_{a}$} \\
\hline$T(K)$ & & & $\mathrm{C}_{3} \mathrm{H}_{4} \mathrm{O}$ & & & \\
\hline 298 & 14.99 & 0 & -12.86 & -54.64 & -82.49 & 139.3 \\
\hline 600 & 26.46 & 0 & -0.500 & -51.16 & -78.12 & 65.53 \\
\hline \multirow[t]{2}{*}{1000} & 43.43 & 0 & 0.660 & -46.04 & -88.81 & 44.70 \\
\hline & \multirow[b]{2}{*}{$\mathrm{C}_{3} \mathrm{H}_{6}$} & \multicolumn{2}{|c|}{$\Delta \mathrm{C}_{\mathrm{p}}^{\circ}\left(\mathrm{cals} / \mathrm{gmole}^{\circ} \mathrm{K}\right)$} & \multirow[b]{2}{*}{$\mathrm{H}_{2} \mathrm{O}$} & \multirow[b]{2}{*}{$\Delta \mathrm{C}_{\mathrm{p}}^{0}$} & \\
\hline$T(K)$ & & $\mathrm{O}_{2}$ & $\mathrm{C}_{3} \mathrm{H}_{4} \mathrm{O}$ & & & \\
\hline 298 & 15.27 & 7.017 & 16.07 & 8.03 & 1.813 & \\
\hline 600 & 25.70 & 7.670 & 25.59 & 8.68 & 0.9000 & \\
\hline 1000 & 34.46 & 8.335 & $3,3.61$ & 9.85 & 0.6650 & \\
\hline
\end{tabular}

$$
\begin{aligned}
& \Delta \mathrm{H}_{\mathrm{R}}^{\circ}=\left\langle\Delta \mathrm{C}_{\mathrm{p}}^{\circ}\right\rangle \mathrm{T}+\Delta \mathrm{H}_{0}^{\circ} ;\left\langle\Delta \mathrm{C}_{\mathrm{p}}^{\circ}\right\rangle=\frac{1.813+0.9000}{2}=1.356 \\
& -80.47=\frac{1.356(298)}{1000}+\Delta \mathrm{H}_{0}^{\circ} ; \Delta \mathrm{H}_{0}^{\circ}=-80.87 \\
& \underline{\Delta \mathrm{H}_{\mathrm{R}}^{\circ}=1.356 \times 10^{-3} \mathrm{~T}-80.87} \\
& \Delta \mathrm{F}_{\mathrm{R}}^{\circ}=\mathrm{IT}+\Delta \mathrm{H}_{0}^{\circ}-\left\langle\mathrm{C}_{\mathrm{p}}^{\circ}\right\rangle \mathrm{T} \operatorname{lnT} \\
& -82.49=\mathrm{I}(298)-80.87-\left(1.356 \times 10^{-3}\right)(298)(\ln 298) ; \mathrm{I}=0.0023 \\
& \Delta \mathrm{F}_{\mathrm{R}}^{\circ}=-80.87+0.0023 \mathrm{~T}-\left(1.356 \times 10^{-3}\right) \mathrm{T} \ln \mathrm{T}
\end{aligned}
$$


TABLE 21 - Hydration of Ethylene Oxide to Form Ethylene Glycol

$$
\mathrm{CH}_{0} \longrightarrow \mathrm{CH}_{2}+\mathrm{H}_{2} \mathrm{O}+\mathrm{HOCH}_{2} \mathrm{CH}_{2} \mathrm{OH}
$$

$$
\Delta \mathrm{H}_{\mathrm{f}}^{\circ}(\mathrm{kcals} / \mathrm{gmole})
$$

\begin{tabular}{|c|c|c|c|c|c|}
\hline$T(K)$ & $\mathrm{C}_{2} \mathrm{H}_{4} \mathrm{O}$ & $\mathrm{H}_{2} \mathrm{O}$ & $\mathrm{C}_{2} \mathrm{H}_{6} \mathrm{O}_{2}$ & $\Delta \mathrm{H}_{\mathrm{R}}^{\circ}$ & \\
\hline 298 & -12.58 & -57.80 & -93.05 & -22.67 & \\
\hline 600 & -14.85 & -58.50 & -94.90 & -21.55 & \\
\hline 1000 & $-16 \cdot 12$ & -59.24 & -95.76 & -20.40 & \\
\hline & & \multicolumn{2}{|c|}{$\Delta \mathrm{F}_{\mathrm{f}}^{\circ}(\mathrm{kcals} / \mathrm{gmole})$} & & \multirow[b]{2}{*}{$\ln \mathrm{K}_{\mathrm{a}}$} \\
\hline$T(K)$ & $\mathrm{C}_{2} \mathrm{H}_{4} \mathrm{O}$ & $\mathrm{H}_{2} \mathrm{O}$ & $\mathrm{C}_{2} \mathrm{H}_{6} \mathrm{O}_{2}$ & $\Delta \mathrm{F}_{\mathrm{R}}^{\circ}$ & \\
\hline 298 & -3.13 & -54.64 & -72.77 & -15.00 & 25.33 \\
\hline 600 & 7.44 & -51.16 & -51.40 & -7.68 & 6.442 \\
\hline \multirow[t]{2}{*}{1000} & 22.74 & -46.04 & -22.09 & 1.21 & -0.6090 \\
\hline & & \multicolumn{2}{|c|}{$\Delta \mathrm{C}_{\mathrm{p}}^{\circ}\left(\mathrm{cals} / \mathrm{gmole}^{\circ} \mathrm{K}\right)$} & \multirow[b]{2}{*}{$\Delta \mathrm{C}_{\mathrm{p}}^{\circ}$} & \\
\hline $\mathrm{T}(\mathrm{K})$ & $\mathrm{C}_{2} \mathrm{H}_{4} \mathrm{O}$ & $\mathrm{H}_{2} \mathrm{O}$. & $\mathrm{C}_{2} \mathrm{H}_{6} \mathrm{O}_{2}$ & & \\
\hline 298 & 11.54 & 8.03 & 23.20 & 3.630 & \\
\hline 600 & 20.62 & 8.68 & 32.72 & 3.420 & \\
\hline 1000 & 27.47 & 9.85 & 39.88 & 2.560 & \\
\hline
\end{tabular}

$$
\begin{aligned}
& \Delta H_{\mathrm{R}}^{\circ}=\left\langle\Delta \mathrm{C}_{\mathrm{p}}^{\circ}\right\rangle \mathrm{T}+\Delta \mathrm{H}_{0}^{\circ} ;\left\langle\Delta \mathrm{C}_{\mathrm{p}}^{\circ}\right\rangle=\frac{3.630+3.420}{2}=3.525 \\
& -22.67=\frac{3.525(298)}{1000}+\Delta \mathrm{H}_{0}^{\circ} ; \Delta \mathrm{H}_{0}^{\circ}=-23.72 \\
& \frac{\Delta \mathrm{H}_{\mathrm{R}}^{\circ}=3.525 \times 10^{-3} \mathrm{~T}-23.72}{\Delta \mathrm{F}_{\mathrm{R}}^{\circ}=\mathrm{IT}+\Delta \mathrm{H}_{0}^{\circ}-\left\langle\Delta \mathrm{C}_{\mathrm{p}}^{\circ}\right\rangle \mathrm{T} \operatorname{lnT}} \\
& -15.00=\mathrm{I}(298)-23.72-\left(3.525 \times 10^{-3}\right)(298)(\ln 298) ; \mathrm{I}=0.0493 \\
& \Delta \mathrm{F}_{\mathrm{R}}^{\circ}=-23.72+0.0493 \mathrm{~T}-\left(3.525 \times 10^{-3}\right) \mathrm{T} \operatorname{lnT}
\end{aligned}
$$


TABLE 22 - Reaction of Propylene Oxide with Water to Form Propylene Glycol<smiles>CC(=CCOCC(O)O)CCO</smiles>

$$
\Delta \mathrm{H}_{\mathrm{f}}^{\circ}(\mathrm{kcal} / \mathrm{gmole})
$$

\begin{tabular}{|c|c|c|c|c|c|}
\hline$T(K)$ & $\mathrm{H}_{2} \mathrm{O}$ & $\mathrm{C}_{3} \mathrm{H}_{6} \mathrm{O}$ & $\mathrm{C}_{3} \mathrm{H}_{8} \mathrm{O}_{2}$ & $\Delta \mathrm{H}_{\mathrm{R}}^{\circ}$ & \\
\hline 298 & -57.80 & -22.17 & -119.3 & -39.33 & \multirow{4}{*}{$\ln \mathrm{K}_{\mathrm{a}}$} \\
\hline 600 & -58.50 & -25.15 & -135.5 & -51.85 & \\
\hline 1000 & -59.24 & -26.72 & -142.2 & -56.24 & \\
\hline \multicolumn{6}{|c|}{$\Delta \mathrm{F}_{\mathrm{f}}^{\circ}(\mathrm{kcal} / \mathrm{gmole})$} \\
\hline $\mathrm{T}(\mathrm{K})$ & $\mathrm{H}_{2} \mathrm{O}$ & $\mathrm{C}_{3} \mathrm{H}_{6} \mathrm{O}$ & $\mathrm{C}_{3} \mathrm{H}_{8} \mathrm{O}_{2}$ & $\Delta \mathrm{F}_{\mathrm{R}}^{0}$ & \\
\hline 298 & -54.64 & -6.16 & -145.3 & -84.50 & 142.7 \\
\hline 600 & -51.16 & 11.36 & -170.1 & -130.3 & 109.3 \\
\hline 1000 & -46.04 & 36.26 & -200.7 & -190.9 & 96.06 \\
\hline \multirow[b]{2}{*}{$\mathrm{T}(\mathrm{K})$} & \multicolumn{3}{|c|}{$\Delta \mathrm{C}_{\mathrm{p}}^{\circ}\left(\mathrm{cal} / \mathrm{gmol} \mathrm{e}^{\circ} \mathrm{K}\right)$} & \multirow[b]{2}{*}{$\Delta \mathrm{C}_{\mathrm{p}}^{\circ}$} & \\
\hline & $\mathrm{H}_{2} \mathrm{O}$ & $\mathrm{C}_{3} \mathrm{H}_{6} \mathrm{O}$ & $\mathrm{C}_{3} \mathrm{H}_{8} \mathrm{O}_{2}$ & & \\
\hline 298 & 8.03 & 17.29 & 24.37 & -0.9500 & \\
\hline 600 & 8.68 & 30.07 & 39.49 & 0.7400 & \\
\hline 1000 & 9.85 & 39.79 & 50.92 & 1.280 & \\
\hline
\end{tabular}

$$
\begin{aligned}
& \Delta \mathrm{H}_{\mathrm{R}}^{\circ}=\left\langle\Delta \mathrm{C}_{\mathrm{p}}^{\circ}\right\rangle \mathrm{T}+\Delta \mathrm{H}_{0}^{\circ} ;\left\langle\Delta \mathrm{C}_{\mathrm{p}}^{\circ}\right\rangle=\frac{-0.9500+0.7400}{2}=-0.1050 \\
& -39.33=\frac{-0.1050(298)}{1000}+\Delta \mathrm{H}_{0}^{\circ} ; \Delta \mathrm{H}_{0}^{\circ}=-39.30 \\
& \frac{\Delta \mathrm{H}_{\mathrm{R}}^{\circ}=-1.050 \times 10^{-4} \mathrm{~T}-39.30}{\Delta \mathrm{F}_{\mathrm{R}}^{\circ}=\mathrm{IT}+\Delta \mathrm{H}_{0}^{\circ}-\left\langle\Delta \mathrm{C}_{\mathrm{p}}^{\circ}>\mathrm{T} \operatorname{lnT}\right.} \\
& -84.50=\mathrm{I}(298)-39.30+\left(1.050 \times 10^{-4}\right)(298)(\ln 298) ; \mathrm{I}=-0.1523 \\
& \Delta \mathrm{F}_{\mathrm{R}}^{\circ}=-39.30-0.1523 \mathrm{~T}+\left(1.050 \times 10^{-4}\right) \mathrm{T} \operatorname{lnT}
\end{aligned}
$$


TABLE 23 - Reaction of Acrolein with Methanol to Yield Methoxypropionaldehyde

$$
\mathrm{CH}_{2}=\mathrm{CH}-\mathrm{CHO}+\mathrm{CH}_{3} \mathrm{OH}+\mathrm{CH}_{3} \mathrm{OCH}_{2} \mathrm{CH}_{2} \mathrm{CHO}
$$

$\Delta H_{f}^{\circ}(\mathrm{kcal} / \mathrm{gmole})$

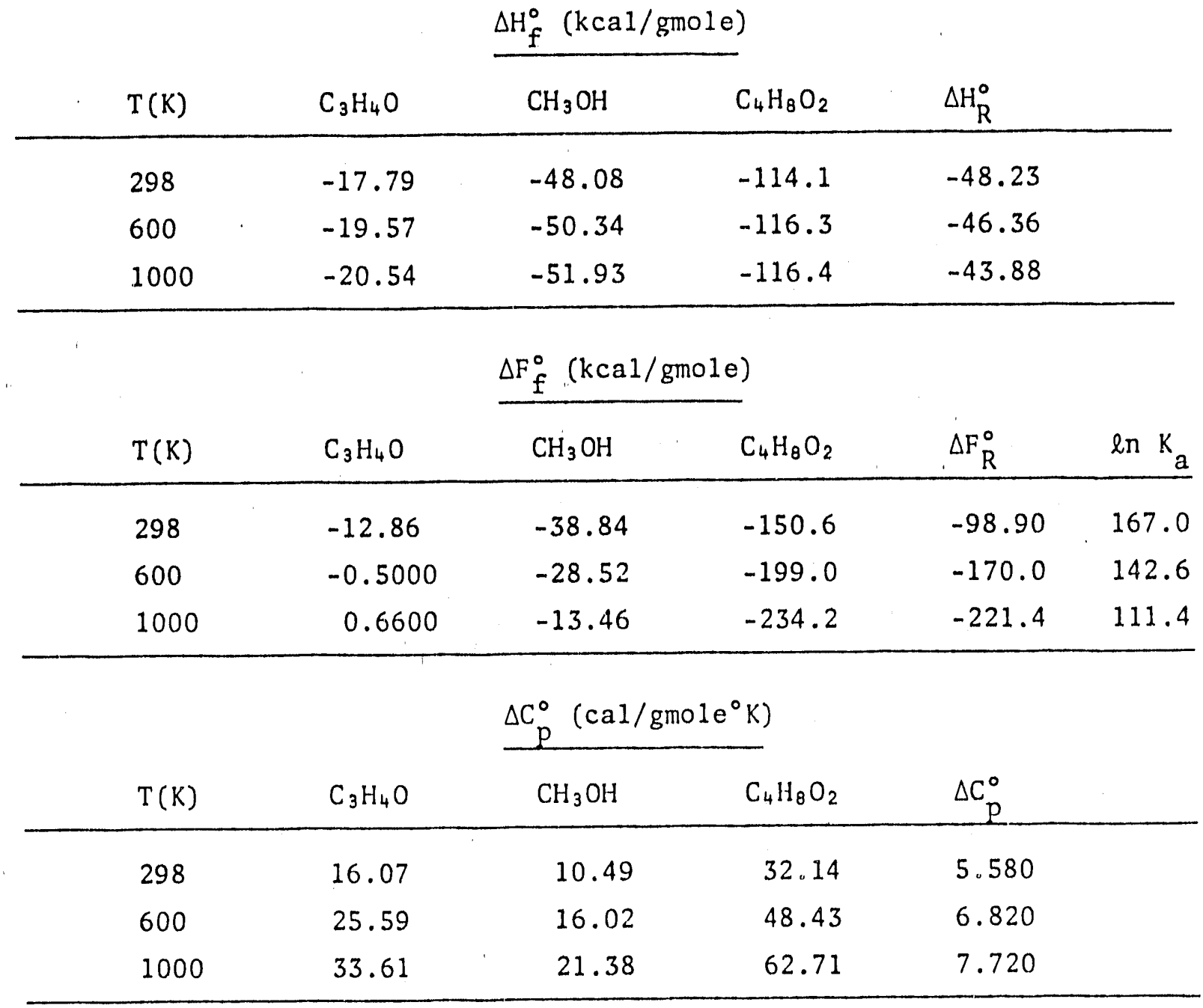

$$
\begin{aligned}
& \Delta H_{\mathrm{R}}^{\circ}=\left\langle\Delta \mathrm{C}_{\mathrm{p}}^{\circ}\right\rangle \mathrm{T}+\Delta \mathrm{H}_{0}^{\circ} ;\left\langle\Delta \mathrm{C}_{\mathrm{p}}^{0}\right\rangle=\frac{6.820+5.580}{2}=6.200 \\
& -48.23=\frac{6.200(298)}{1000}+\Delta \mathrm{H}_{0}^{\circ} ; \Delta \mathrm{H}_{0}^{\circ}=-50.08 \\
& \frac{\Delta \mathrm{H}_{\mathrm{R}}^{\circ}=6.200 \times 10^{-3} \mathrm{~T}-50.08}{\Delta \mathrm{F}_{\mathrm{R}}^{\circ}=\mathrm{IT}+\Delta \mathrm{H}_{0}^{\circ}-\left\langle\Delta \mathrm{C}_{\mathrm{p}}^{\circ}\right\rangle \mathrm{T} \operatorname{lnT}} \\
& -98.90=\mathrm{I}(298)-50.08-\left(6.200 \times 10^{-3}\right)(298)(\ln 298) ; \mathrm{I}=-0.128: \\
& \Delta \mathrm{F}_{\mathrm{R}}^{\circ}=-50.08-0.1285 \mathrm{~T}-\left(6.200 \times 10^{-3}\right) \mathrm{T} \operatorname{lnT}
\end{aligned}
$$


TABLE 24 - Reaction of Acrolein with Isopropanol to Yield Allyl Alcohol and Acetone

$$
\mathrm{CH}_{2}=\mathrm{CH}-\mathrm{CHO}+\mathrm{CH}_{3} \mathrm{CH}(\mathrm{OH}) \mathrm{CH}_{3} \rightarrow \mathrm{CH}_{2}=\mathrm{CHCH}_{2} \mathrm{OH}+\mathrm{CH}_{3} \mathrm{COCH}_{3}
$$

$$
\Delta H_{f}^{\circ}(k c a l s / g m o l e)
$$

\begin{tabular}{|c|c|c|c|c|c|c|}
\hline $\mathrm{T}^{\prime}(\mathrm{K})$ & $\mathrm{C}_{3} \mathrm{H}_{4} \mathrm{O}$ & $\mathrm{C}_{3} \mathrm{H}_{8} \mathrm{O}$ & $\mathrm{C}_{3} \mathrm{H}_{6} \mathrm{O}$ & $\mathrm{C}_{3} \mathrm{H}_{6} \mathrm{O}$ & $\Delta \mathrm{H}_{\mathrm{R}}^{\circ}$ & \\
\hline 298 & -17.79 & -65.15 & -31.55 & -52.00 & -0.610 & \\
\hline 600 & -19.57 & -68.74 & -34.39 & -55.07 & -1.150 & \\
\hline 1000 & $-2 \quad 54$ & -70.58 & -36.11 & -56.93 & -1.920 & \\
\hline \multicolumn{7}{|c|}{$\Delta F_{f}^{\circ}(\mathrm{kcals} /$ gmole $)$} \\
\hline $\mathrm{T}(\mathrm{K})$ & $\mathrm{C}_{3} \mathrm{H}_{4} \mathrm{O}$ & $\mathrm{C}_{3} \mathrm{H}_{8} \mathrm{O}$ & $\mathrm{C}_{3} \mathrm{H}_{6} \mathrm{O}$ & $\mathrm{C}_{3} \mathrm{H}_{6} \mathrm{O}$ & $\Delta I_{\mathrm{R}}^{\circ}$ & $\ln \mathrm{K}_{\mathrm{a}}$ \\
\hline 298 & -12.86 & -41.49 & -17.03 & -36.58 & 0.7400 & -1.250 \\
\hline 600 & -0.5000 & -15.94 & -1.09 & -19.65 & -4.300 & 3.607 \\
\hline \multirow[t]{2}{*}{1000} & 0.6600 & 19.93 & 21.70 & 4.61 & 5.720 & -2.879 \\
\hline & & \multicolumn{2}{|c|}{$\Delta \mathrm{C}_{\mathrm{p}}^{0}\left(\mathrm{cals} / \mathrm{gmole}^{\circ} \mathrm{K}\right)$} & \multirow[b]{2}{*}{$\mathrm{C}_{3} \mathrm{H}_{6} \mathrm{O}$} & \multirow[b]{2}{*}{$\Delta \mathrm{C}_{\mathrm{p}}^{\circ}$} & \\
\hline $\mathrm{T}(\mathrm{K})$ & $\mathrm{C}_{3} \mathrm{H}_{4} \mathrm{O}$ & $\mathrm{C}_{3} \mathrm{H}_{8} \mathrm{O}$ & $\mathrm{C}_{3} \mathrm{H}_{6} \mathrm{O}$ & & & \\
\hline 298 & 16.07 & 21.21 & 18.17 & 17.90 & -1.210 & \\
\hline 600 & 25.59 & 35.76 & 30.11 & 29.34 & -1.900 & \\
\hline 1000 & 33.61 & 46.82 & 39.06 & 39.15 & -2.220 & \\
\hline
\end{tabular}

$$
\begin{aligned}
& \Delta H_{\mathrm{R}}^{\circ}=\left\langle\Delta \mathrm{C}_{\mathrm{p}}^{\circ}\right\rangle \mathrm{T}+\Delta \mathrm{H}_{0}^{\circ} ; \Delta \mathrm{C}_{\mathrm{p}}^{\circ}=\frac{-1.210-1.900}{2}=-1.555 \\
& -0.610=\frac{-1.555(298)}{1000}+\Delta H_{0}^{\circ} ; \Delta \mathrm{H}_{0}^{\circ}=-0.1466 \\
& \frac{\Delta \mathrm{H}_{\mathrm{R}}^{\circ}=-1.555 \times 10^{-3} \mathrm{~T}-0.1466}{\Delta \mathrm{F}_{\mathrm{R}}^{\circ}=\mathrm{IT}+\Delta \mathrm{H}_{0}^{\circ}-\left\langle\Delta \mathrm{C}_{\mathrm{p}}^{\circ}\right\rangle \mathrm{T} \operatorname{lnT}} \\
& 0.7400=\mathrm{I}(298)-0.1466+\left(1.555 \times 10^{-3}\right)(298)(\ln 298) ; \mathrm{I}=-0.0059 \\
& \Delta F_{\mathrm{R}}^{\circ}=-0.1466-0.0059 \mathrm{~T}+\left(1.555 \times 10^{-3}\right) \mathrm{T} \operatorname{lnT} .
\end{aligned}
$$


TABLE 25 - Oxidation of Allyl Alcohol to Glycerin with Hydrogen Peroxide

$\mathrm{CH}_{2}=\mathrm{CHCH} \mathrm{OH}_{2}+\mathrm{H}_{2} \mathrm{O}_{2}+\mathrm{CH}_{2} \mathrm{OH}-\mathrm{CHOH}-\mathrm{CH}_{2} \mathrm{OH}$

\begin{tabular}{|c|c|c|c|c|c|}
\hline \multirow[b]{2}{*}{$\mathrm{T}(\mathrm{K})$} & \multirow[b]{2}{*}{$\mathrm{C}_{3} \mathrm{H}_{6} \mathrm{O}$} & \multicolumn{2}{|c|}{$\Delta H_{f}^{\circ}(\mathrm{kcals} / \mathrm{gmole})$} & \multirow[b]{2}{*}{$\Delta \mathrm{H}_{\mathrm{R}}^{\circ}$} & \\
\hline & & $\mathrm{H}_{2} \mathrm{O}_{2}$ & $\mathrm{C}_{3} \mathrm{H}_{8} \mathrm{O}_{3}$ & & \\
\hline 298 & -31.55 & -32.53 & -159.8 & -95.72 & \\
\hline 600 & -34.39 & -33.22 & -182.6 & -115.0 & \\
\hline 1000 & -36.11 & -33.57 & -184.2 & -114.5 & \\
\hline \multirow[b]{2}{*}{$\mathrm{T}(\mathrm{K})$} & \multirow[b]{2}{*}{$\mathrm{C}_{3} \mathrm{H}_{6} \mathrm{O}$} & \multicolumn{2}{|c|}{$\Delta \mathrm{F}_{\mathrm{f}}^{\circ}(\mathrm{kcals} / \mathrm{gmole})$} & \multirow[b]{2}{*}{$\Delta \mathrm{F}_{\mathrm{R}}^{0}$} & \multirow[b]{2}{*}{$\ln \mathrm{K}_{\mathrm{a}}$} \\
\hline & & $\mathrm{H}_{2} \mathrm{O}_{2}$ & $\mathrm{C}_{3} \mathrm{H}_{8} \mathrm{O}_{3}$ & & \\
\hline 298 & -17.03 & -25.21 & -114.02 & -71.78 & 121.2 \\
\hline 600 & -1.09 & -17.47 & -66.84 & -48.28 & 40.50 \\
\hline 1000 & 21.70 & -6.85 & -3.730 & -18.58 & 9.351 \\
\hline \multirow[b]{2}{*}{$\mathrm{T}(\mathrm{K})$} & \multicolumn{3}{|c|}{$\Delta \mathrm{C}_{\mathrm{p}}^{0}\left(\mathrm{cals} / \mathrm{gmole}^{\circ} \mathrm{K}\right)$} & \multirow[b]{2}{*}{${ }_{p}^{0}$} & \\
\hline & $\mathrm{C}_{3} \mathrm{H}_{6} \mathrm{O}$ & $\mathrm{H}_{2} \mathrm{O}_{2}$ & $\mathrm{C}_{3} \mathrm{H}_{8} \mathrm{O}_{3}$ & & \\
\hline 298 & 18.17 & 10.31 & 40.92 & 12.44 & \\
\hline 600 & 30.11 & 13.31 & 43.35 & -0.07 & \\
\hline 1000 & 39.06 & 15.02 & 55.06 & 0.98 & \\
\hline
\end{tabular}

$\Delta \mathrm{H}_{\mathrm{R}}^{\circ}=\left\langle\Delta \mathrm{C}_{\mathrm{p}}^{\circ}\right\rangle \mathrm{T}+\Delta \mathrm{H}_{0}^{\circ} ;\left\langle\Delta \mathrm{C}_{\mathrm{p}}^{\circ}\right\rangle=\frac{12.44-0.07}{2}=6.185$

$-95.72=\frac{6.185(298)}{1000}+\Delta H_{0}^{\circ} ; \Delta H_{0}^{\circ}=-97.56$

$\Delta \mathrm{H}_{\mathrm{R}}^{\circ}=6.185 \times 10^{-3} \mathrm{~T}-97.56$

$\Delta \mathrm{F}_{\mathrm{R}}^{\circ}=\mathrm{IT}+\Delta \mathrm{H}_{\circ}^{\circ}-\left\langle\Delta \mathrm{C}_{\mathrm{p}}^{\circ}>\mathrm{T} \operatorname{lnT}\right.$

$-71.78=I(298)-97.56-\left(6.185 \times 10^{-3}\right)(298)(\ln 298) ; I=0.1217$

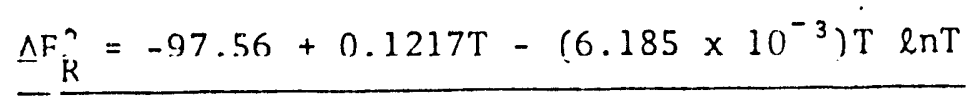


TABLE 26 - Price/Cost Ratios, Oxidation Products

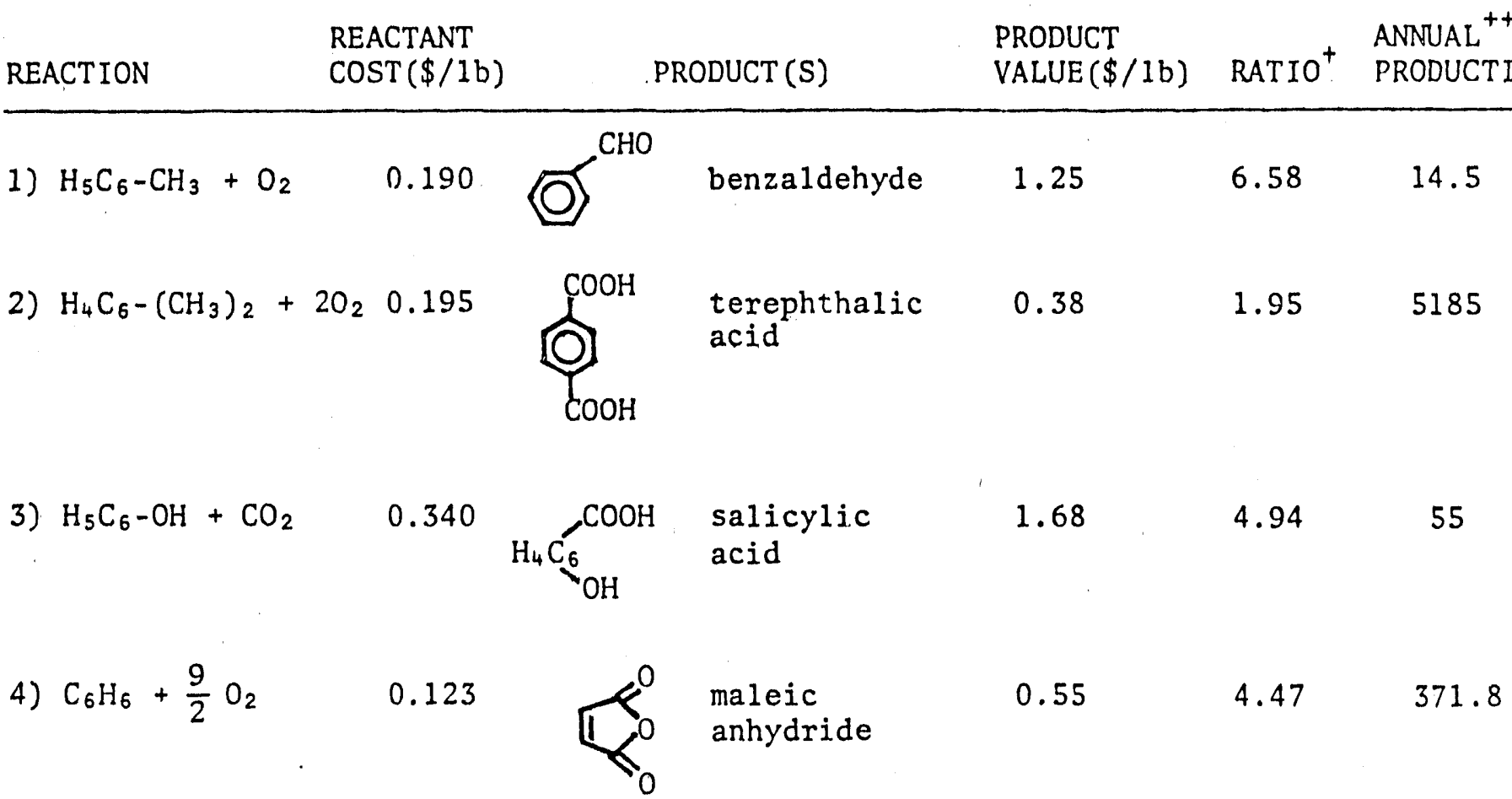
1) $\mathrm{C}_{2} \mathrm{H}_{4}+\frac{1}{2} \mathrm{O}_{2}$
$0.180 \quad \mathrm{CH}_{3} \mathrm{CHO}$ acetaldehyde
0.37
2.06
625
2) $\mathrm{C}_{2} \mathrm{H}_{4}+\frac{1}{2} \mathrm{O}_{2}$
0.180
$\mathrm{CH}_{2}=\mathrm{CH}_{2}$ oxide
0.35
1.94
5833
3) $\mathrm{CH}_{2}=\mathrm{CHCH}_{3}+\frac{1}{2} \mathrm{O}_{2}$
0.154
$\begin{array}{ll}\mathrm{CH}_{3} \underset{\mathrm{CH}}{\mathrm{CH}_{2}} & \text { propylene } \\ \mathrm{O}^{\prime} & \text { oxide }\end{array}$
0.48
3.12
2210
4) $\mathrm{CH}_{2}=\mathrm{CHCH}_{3}+\mathrm{O}_{2}$
$0.154 \mathrm{CH}_{2}=\mathrm{CHCHO}$ acrolein
0.62
4.03
16
5) $\mathrm{C}_{2} \mathrm{H}_{4} \mathrm{O}+\mathrm{H}_{2} \mathrm{O}$
$0.355 \mathrm{HOCH}_{2} \mathrm{CH}_{2} \mathrm{OH}$ ethylene
0.31
0.87
4823
6) $\mathrm{C}_{3} \mathrm{H}_{6} \mathrm{O}+\mathrm{H}_{2} \mathrm{O}$

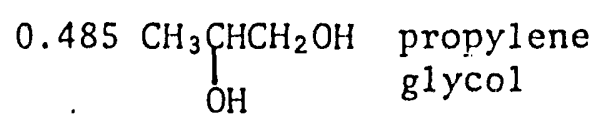
0.43
0.89
615

7) $\mathrm{CH}_{2}=\mathrm{CHClOO}+\mathrm{CH}_{3} \mathrm{OH}$

0.699

$\mathrm{CH}_{3} \mathrm{OCH}_{2} \mathrm{CH}_{2} \mathrm{CHO}$

$\sim 0.90$

1.29

231.1

methoxypropionaldehyde

8) $\mathrm{CH}_{2}=\mathrm{CH}-\mathrm{CHO}+$ $0.827 \mathrm{CH}_{2}=\mathrm{CHCH}_{2} \mathrm{OH}$ allyl alcohol

1.17

1.41

1873

$\mathrm{CH}_{3} \mathrm{CH}(\mathrm{OH}) \mathrm{CH}_{3}$

$\mathrm{CH}_{3} \mathrm{COCH}_{3}$ acetone

9) $\mathrm{CH}_{2}=\mathrm{CHCH}_{2} \mathrm{OH}+\mathrm{H}_{2} \mathrm{O}_{2} 1.13 \quad \mathrm{CH}_{2} \mathrm{OH}-\mathrm{CHOH}-\mathrm{CH}_{2} \mathrm{OH}$

0.91

0.81

315

glycerine

+ Product Price/Reactant(s) Cost

$+10^{6} \mathrm{lbs} / \mathrm{yr}$ 
A number of commercial processes are employed to synthesize the desired chemical products. Conventional methods for producing several high $\$$-value chemicals are discussed as well as processes used by some major companies that directly relate to the paths proposed in this report. The commercial processes discussed follow, in general, the sequence of products listed in Table 5 .

Prior to 1955 benzene was produced primarily from coal gas as a byproduct of steel manufacturing. Typically one ton of coal yields $1.85-2.40$ gallons of benzene [14]; the process flow is shown in Figure 4. By the 1970's however, about $94 \%$ of aromatics were produced from petroleum. The petroleum derived methods include [14]: 1) catalytic reforming (conversion of naphthenes to aromatics), shown in Figure 5 ; 2) hydrodealkylation (HDA) of toluene; 3) extraction from pyrolysis gasoline; and 4) disproportionation of toluene. Very recently a new process has appeared, called the dehydrocyclization of n-paraffins to aromatics [19], which eliminates the use of noble metal catalyst: and hydrogen with the feedstock.

Phenol can be obtained from several sources. These methods include [14]: 1) a benzene sulfonate process requiring cheap sulfuric acid and caustic soda (the disposal of sodium sulfate and sodium sulfite must be considered); 2) a chlorobenzene process requiring low cost chlorine; 3) a regenerative (Raschig) process requiring large scale continuous units; and more recently, 4) a cumene peroxidation process requiring cheap acetone; and 5) a toluene oxidation proces Aniline is most typically produced by catalytic reduction of nitrobenzene in the presence of Raney nickel [15]. Acetanilide is manufactured from refluxi aniline and acetic acid for 6-14 hours [15]. Aniline can be alkylated in the presence of sodamide to give a $75 \%$ yield of ethylaniline [16]. Mixtures of 2-ethylaniline and 2,6-diethylaniline are obtained in high yield when aniline 


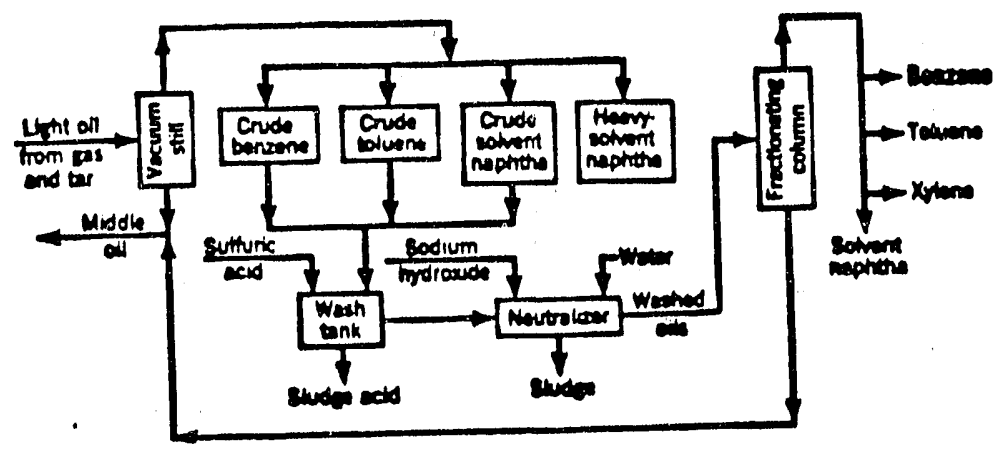

Figure 4. Aromatics from Coal Gas and Tar Light Oil [14]

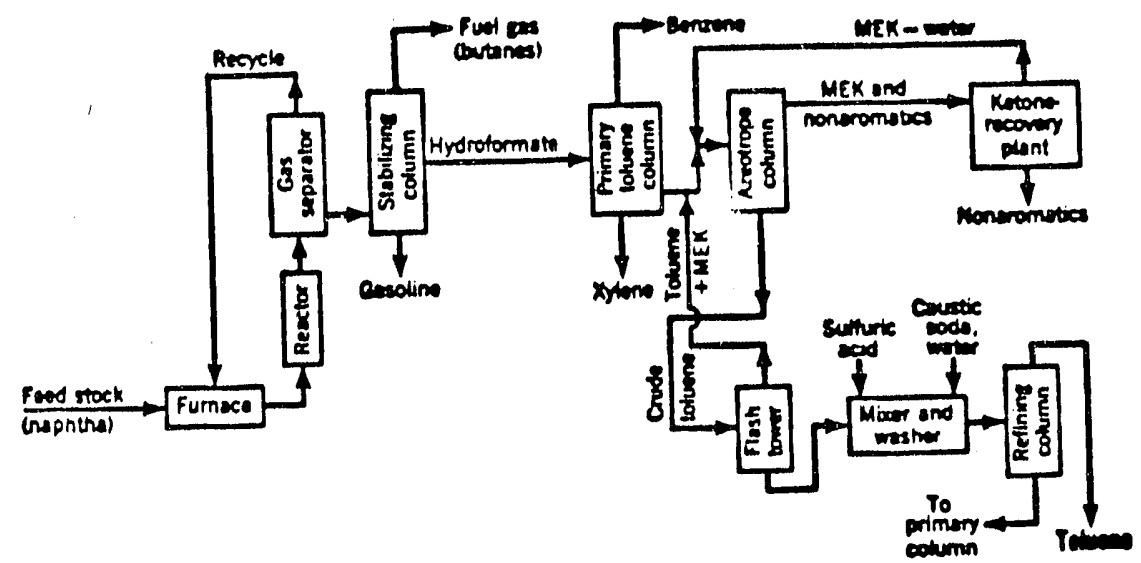

Reaction (Typical)

$$
\begin{gathered}
\underset{\text { Methyl erclobexane }}{\mathrm{C}_{6} \mathrm{H}_{11} \mathrm{CH}_{3}} \rightarrow \underset{\text { Tolwow }}{\mathrm{C}_{6} \mathrm{H}_{8} \mathrm{CH}_{8}}+3 \mathrm{H}_{2} \\
80-90 \% \text { conversion }
\end{gathered}
$$

Figure 5. Aromatics from Petroleum by Reforming [14] 
is heated with ethylene at $200-300^{\circ} \mathrm{C}$ under pressure in the presence of aluminum anilide.

Resorcinol, hydroquinone, and catechol are isomers of dihydroxybenzene [16] Sodium dichrornate or manganese dioxide can be used to oxidize aniline, with a $90 \%$ conversion to hydroquinone. Catechol can be manufactured by hydrolysis cf o-chlorophenol in aqueous sodium hydroxide with copper sulfate as catalyst. In the presence of ferrous catalyst, hydroxylation of phenol with hydrogen peroxide directly gives catechol and hydroquinone. Resorcinol and hydroquinone can be prepared from the appropriate isomer of diisopropyl benzene (DIPB) using silica-alumina catalyst, producing $78 \%$ yield.

Several methods exist for the production of cresol. Cresol is obtained by refining tar acids, the phenolic constituents present in coal tar [14]. Small amounts of cresol are recovered from cracked naphtha. It can also be produced synthetically by the sulfonation of toluene followed by hydrolysis. Cumene oxidation is another synthesis method. Spence and Sons [17] synthesizes cresols by the alkylation of phenol with methanol; this catalytic $\left(\mathrm{Al}_{2} \mathrm{O}_{3}\right)$ process can be operated in fixed-bed or fluid bed, at temperatures of $340-355^{\circ} \mathrm{C}$

Salicylic acid can be made by treating phenol with sodium hydroxide, followed by treatment with dry carbon dioxide gas and precipitation with acid [14].

Benzaldehyde is an industrially important organic used in the production of dyes, pharmaceuticals, and perfumeries. Any of three different methods is employed, depending upon the desired use of the product [16]: 1) Rhone-Poulenc S.A. [18] uses a catalytic $\left(\mathrm{V}_{2} \mathrm{O}_{5} / \mathrm{SiO}_{2}-\mathrm{Al}_{2} \mathrm{O}_{3}\right)$ vapor phase air oxidation process operated ir fixed- or fluid bed, at a ternperature of $\sim 400^{\circ} \mathrm{C}$, which simultancousl produces benzaldehyde and benzoic acid; 2) Liquid phase oxidation of toluene is recommended for small scale production; 3) If chlorine free benzaldehyde is not required, liquid phase chlorination of toluene is the cheapest route. 
Benzyl alcohol is manufactured on a comercial scale from benzyl chloride and sodium carbonate with a yield of $70-72 \%$ [16]. The still residues from this process can be distilled separately to yield benzyl ether as a by-product.

2,4-xylidine and 2,5-xylidine are widely employed in the dye industry [16]. They are usually obtained by iron reduction of nitrobenzene.

Guaiacol can be prepared by the mercuric oxide oxidation of lignin, the zinc chloride reduction of acetovanillone, and diazolization and hydrolysis of o-arisidine [16].

As discussed previously, the conversion of $n$-paraffins to aromatics also results in the production of olefins, such as ethylene and propylene. The Shell Development Company [20] utilizes a direct oxidation process to form epoxides. This catalytic vapor phase oxidation process at $327^{\circ} \mathrm{C}$ in fixedor fluid bed has conversions of $50-70 \%$, also producing some complete oxidation products, $\mathrm{CO}_{2}$ and $\mathrm{H}_{2} \mathrm{O}$. 


\section{CONCLUSIONS AND RECOMMENDATIONS}

The original objective of the report was to present a list of endothermic chemical reactions, which could utilize broad band IR-VIS-UV radiation, to synthesize high \$-value products from low cost feedstocks. In the intervening year and a half since the original report, laboratory experiments have been conducted, more literature search and calculations have been carried out, and a broader view of the entire project has evolved.

Two additional considerations have been recognized: 1)-the dehydrocyclization of $C_{6}-C_{8}$ n-paraffins to aromatics also produces a significant fraction of $\mathrm{C}_{2}-\mathrm{C}_{3}$ olefins; and 2)-a cost effective solar chemical plant must utilize its equipment during the night-time as well as the day-light hours. The combination of these two facts leads to the possibility of carrying out exothermic olefin oxidation reactions during the night-time hours.

\section{Conclusions are:}

1) -pricewise chemicals fall into four (4) ascending value classes: primary feedstocks, intermediates, products, and specialty products $(>\$ 1.00 / 1 \mathrm{~b})$;

2) -conversion of paraffins to aromatics appears to be a very important primary step towards high $\$$-value products;

3 ) -the endothermic dehydrocyclization of $C_{6}-C_{8}$ n-paraffins to aromatics, followed by alkylation and hydroxylation of the aromatic ring can lead to a class of high $\$$-value products;

4) - the product price to reactant(s) cost ratio values are in the range of 5 to 8 for the best reaction possibilities;

$5)$ - to be cost effective catalyst choice for paraffin to aromatic conversi should optimize aromatic $w^{\circ}$ yield $>60^{\circ}$;

6) - the conversion of olefins to oxygenated compounds is an important supplement to producing an overall cost effective process.

Recommendations are:

1) -that the initial experimental reaction sequence should be, n-paraffins to aromatics to alkylated-hydroxylated rings; and,

2) -then followed by experiments on the oxidation of $\mathrm{C}_{2}-\mathrm{C}_{3}$ olefins to judicious choices amongst epoxides, aldehydes, glycols, alcohols, and ketones. 
SELECTED REFERENCES

[1] Wentworth, W.E., C.F. Batten, Gong We1, "The Photo-Assisted Thermal Decomposition of Methanol and Isopropanol in a Fluldized Bed."

[2] Lawler, Glorla M., ed. "Chemlcal Orlgins And Markets," 5th edition, Stanford Research Institute, Calif., 1977.

[3] "Top 50 Chemlcals," C\&E News, p. 35, June 9, 1986.

[4] "Chemical Prices," Chemical Marketing Reporter, published by Schnell Publishing Company, Inc., New York, Pp. 32-39, June $9,1986$.

[5] Prengle, H.W., Private Communications, $8 / 86$ to $12 / 86$.

[6] Stull, Daniel R., Edgar F. Westrum, Jr., and Gerald C. Sinke, "The Chemlcal Thermodynamics of Organlc Compounds," John Wiley \& Sons, New York, 2969.

[7] Reld, Robert C., John M. Prausn1tz, and Thomas K. Sherwood, "The Properties of Gases and LIqu1ds," Jrd ed., McGraw-H1ll Book Company, New York, 1977.

[8] Weast, Robert C., ed., CRC Handbook of Chem1stry and Physics," 61st edition, CRC Press, Florlda 1980.

[9] Streltwleser, Andrew, Jr., and Clayton H. Heathcock, "Introduction to Organic Chemistry," Macmilian Publishing Co., New York, 1981.

[10] Hatch, Lewis F., "The Chemistry of Petrochemical Reactions," Gulf Publishing Company, Houston, Texas, 1955.

[11] Schuster, Herbert F. and Gary M. Coppola, "Allenes in Organlc Synthes1s," John Wliey \& Sons, New York, 1984.

[12] Timmons, C.J., ed., "Modern Reactions in Organic Synthesis," Van Nostrand Relnhold Company, 1970.

[13] Saghaf1, Maj1d, Senior Honors Thes1s on: "Fundamental Mechanlsms of Photo-Thermal Catalysts."

[14] Falth, W.L., Donald B. Keyes, Ronald L. Clark, "Industr1al Chemlcals," 3rd ed., John Wlley \& Sons, New York, 1965.

[15] McKetta, J.J., "Chemical Processing and Design," Vol 1-14, Marcel Decker, Inc., New York, 1976.

[16] Kirk - Othmer, "Encyclopedia of Chemical Technology," 3rd ed., vol 1-24, John Wlley \& Sons, Ney York, 1978. 
[17] N.M. Cullinane and W.C. Davies, Brit. Pat. \#600,837, 20 Apr 1948; ibid, Brit. Pat., \#600,838, 20 Apr 1948; ibid, Brit. Pat. \#602,257. 24 May 1948.

[18] J. Bonnart and G. Poilane, U.S. Pat. \#3,387,036, 4 June 1969; J.C. Brunie, U.S. Pat. \#3,658,875, 25 Apr 1972; M. Jouffret, U.S. Pat. \#3,948,995, 6 Apr 1976.

[19] F-M Lee, "Catalytic Dehydrocyclization-Dehydrogenation of Hydrocarbons" U.S. Patent \#4,607,129 (1986).

[20] She11 Development Company, U.S. Pat., \#3,119,837, (1964). 


\section{APPENDIX}

A. Estimation of Thermodynamic Properties

For the estimation of heats of formation, $\Delta H_{f}^{0}$, and free energies of formation, $\Delta \mathrm{F}_{\mathrm{f}}^{0}$, an accurate method has been developed by Benson and his colleagues [6-8]. It is a group-contribution method applicable for $C_{p}^{\circ}, \Delta H_{f 298}^{\circ}$, and $\Delta S_{298}^{\circ}$. Once ihese fundamental properties are obtained, the free energy of formation and the properties at elevated temperatures can be calculated using the following relationships.

$$
\begin{aligned}
& \Delta \mathrm{F}_{\mathrm{T}}^{\circ}=\Delta \mathrm{H}_{\mathrm{T}}^{\circ}-\mathrm{T} \Delta \mathrm{S}_{\mathrm{T}}^{\circ} \\
& \Delta \mathrm{H}_{\mathrm{fT}}^{\circ}=\Delta \mathrm{H}_{\mathrm{f} 298}^{\circ}+\int_{298}^{\mathrm{T}} \Delta \mathrm{C}_{\mathrm{p}}^{\circ} \mathrm{dT} \\
& \Delta \mathrm{S}_{\mathrm{T}}^{\circ}=\Delta \mathrm{S}_{298}^{\circ}+\int_{298}^{\mathrm{T}} \Delta \mathrm{C}_{\mathrm{p}}^{\circ} \mathrm{d} \ln \mathrm{T}
\end{aligned}
$$

Contributions are given for atoms with valences greater than one. It is necessary to become familiar with the notation used in Table A-l to employ this method. For example, contributions for a methyl group attached to a carbon atom, $-\mathrm{CH}_{3}$, are represented as $\mathrm{C}-(\mathrm{C})(\mathrm{H})_{3}$. For a description of other shorthand used, refer to the footnotes following Table $A-1$.

To demonstrate the method for future use, the following example is provided. example: Estimation of $\Delta H_{f 298}^{\circ}$ and $\Delta S^{\circ} 298$ for $m-c r e s o l$,

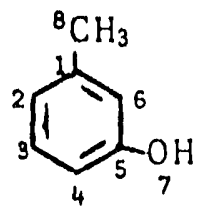

\begin{tabular}{ccccc}
$\#$ & atom & notation & $\Delta H_{f 298}^{\circ}$ & \multicolumn{1}{c}{$\Delta S_{298}^{\circ}$} \\
\hline 4 & $2,3,4,6$ & $C_{B}-(H)$ & 3.30 & 11.53 \\
1 & 5 & $C_{B}-(0)$ & -0.90 & -10.20 \\
1 & 1 & $C_{B}-(C)$ & 5.51 & -7.69 \\
1 & 7 & $0-\left(C_{B}\right)(H)$ & -37.9 & 29.1 \\
1 & 8 & $C-\left(C_{B}\right)(H)_{3}$ & -10.8 & 30.41 \\
\hline$\Sigma$ & & & -30.17 & 87.74
\end{tabular}

$\frac{\text { actual values }}{H_{f 298}^{\circ}=-31.63}$

$S_{298}^{0}=85.27$ 


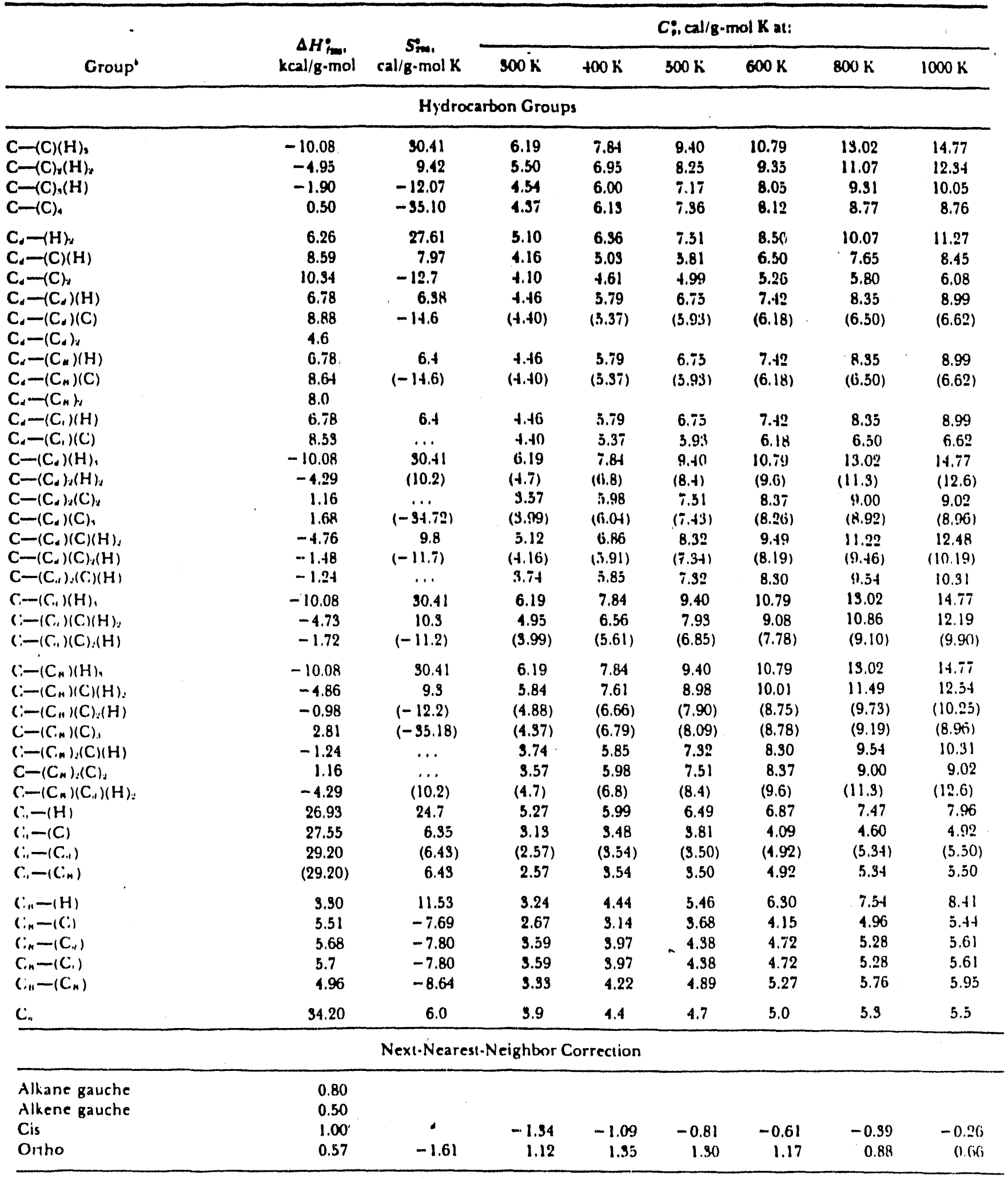


$C_{\text {: cal } / \mathrm{g}-\mathrm{mol} \mathrm{K} \text { at: }}$

\begin{tabular}{|c|c|c|c|c|c|c|c|c|}
\hline \multirow[b]{2}{*}{ Ring $(\sigma)^{0.1}$} & \multirow{2}{*}{$\begin{array}{c}\Delta H_{i m i}^{\circ} \\
k \mathrm{cal} / \mathrm{R}-\mathrm{mol}\end{array}$} & \multirow{2}{*}{ 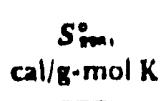 } & \\
\hline & & & $300 \mathrm{~K}$ & $400 \mathrm{~K}$ & $500 \mathrm{~K}$ & $600 \mathrm{~K}$ & $800 \mathrm{~K}$ & $1000 \mathrm{~K}$ \\
\hline \multicolumn{9}{|c|}{ Corrections to be Applied for Ring Cumpounds } \\
\hline $\begin{array}{l}\text { Cyclupropane (6) } \\
\text { Cyclopropene }(2) \\
\text { Cyclobutane (8) } \\
\text { Cyclobutene (2) } \\
\text { Ciycinpentane (10) }\end{array}$ & $\begin{array}{r}27.6 \\
53.7 \\
26.2 \\
29.8 \\
6.3\end{array}$ & $\begin{array}{l}32.1 \\
33.6 \\
29.8 \\
29.0 \\
27.3\end{array}$ & $\begin{array}{l}-3.05 \\
-4.61 \\
-2.53 \\
-6.5\end{array}$ & $\begin{array}{l}-2.53 \\
-3.89 \\
-2.19 \\
-5.5\end{array}$ & $\begin{array}{l}-2.10 \\
-9.14 \\
-1.89 \\
-4.5\end{array}$ & $\begin{array}{l}-1.90 \\
-2.64 \\
-1.68 \\
-3.8\end{array}$ & $\begin{array}{l}-1.77 \\
-1.88 \\
-1.48 \\
-2.8\end{array}$ & $\begin{array}{l}-1.62 \\
-1.38 \\
-1.313 \\
-1.8\end{array}$ \\
\hline $\begin{array}{l}\text { Cyclopentene (2) } \\
\text { Cyclopentadiene } \\
\text { Cyclohexane (6) } \\
\text { Cycluhexene (2) } \\
\text { Cycloheptane (1) } \\
\text { Cyclnoctane (8) } \\
\text { Naphthaiene }\end{array}$ & $\begin{array}{l}5.9 \\
6.0 \\
0 \\
1.4 \\
6.4 \\
9.9 \\
\cdots\end{array}$ & $\begin{array}{r}25.8 \\
28.0 \\
18.8 \\
21.5 \\
15.9 \\
16.5 \\
8.1\end{array}$ & $\begin{array}{l}-5.98 \\
-1.3 \\
-5.8 \\
-4.28\end{array}$ & $\begin{array}{l}-5.35 \\
-4.1 \\
-3.04\end{array}$ & $\begin{array}{l}-4.89 \\
-2.9 \\
-1.98\end{array}$ & $\begin{array}{l}-4.14 \\
-1.3 \\
-1.19\end{array}$ & $\begin{array}{c}-2.93 \\
1.1 \\
-0.29\end{array}$ & $\begin{array}{c}-2.20 \\
2.2 \\
0.11\end{array}$ \\
\hline
\end{tabular}


Table A-1 Benson Group Contributions to Ideal-Gas Propertien: (Continued)

\begin{tabular}{|c|c|c|c|c|c|c|c|c|}
\hline \multirow[b]{2}{*}{ Group' } & \multirow{2}{*}{$\begin{array}{c}\Delta H_{i \text { ind }}^{\circ} \\
\mathrm{kcal} / \mathrm{g} \cdot \mathrm{mol}\end{array}$} & \multirow{2}{*}{$\underset{\mathrm{cal} / \mathrm{g} \cdot \mathrm{mol} \mathrm{K}}{S_{\mathrm{m}}}$} & \multicolumn{6}{|c|}{$C_{n !}^{\circ}$ cailg $/ \mathrm{mol} \mathrm{K}$ at: } \\
\hline & & & $300 \mathrm{~K}$ & $400 \mathrm{~K}$ & $500 \mathrm{~K}$ & $600 \mathrm{~K}$ & $800 \mathrm{~K}$ & $1000 \mathrm{~K}$ \\
\hline \multicolumn{9}{|c|}{ Oxygen-containing Compounds } \\
\hline $\mathrm{CO}-(\mathrm{CO})(\mathrm{H})$ & -26.0 & $\ldots$ & 6.72 & 7.83 & 8.90 & 9.89 & 11.43 & 12.12 \\
\hline $\mathrm{CO}-(\mathrm{CO})(\mathrm{C})$ & -29.2 & $\ldots$ & 5.46 & 6.32 & 7.16 & 7.87 & 9.00 & 9.76 \\
\hline $\mathrm{CO}-(\mathrm{O})\left(\mathrm{C}_{d}\right)$ & -32.5 & $\ldots$ & 5.97 & 6.7 & 7.41 & 8.02 & 8.87 & 9.36 \\
\hline $\mathrm{CO}-(\mathrm{O})\left(\mathrm{C}_{2}\right)$ & -32.5 & $\ldots$ & 2.18 & 2.75 & 3.98 & 5.03 & 6.29 & 7.06 \\
\hline $\mathrm{CO}-(\mathrm{O})(\mathrm{C})$ & -35.1 & 4.78 & 5.97 & 6.70 & 7.40 & 8.02 & 8.87 & 9.36 \\
\hline $\mathrm{CO}-(\mathrm{O})(\mathrm{H})$ & -32.1 & 34.93 & 7.03 & 7.87 & 8.82 & 9.68 & 11.16 & 12.20 \\
\hline $\mathrm{CO}^{-}\left(\mathrm{C}_{d}\right)(\mathrm{H})$ & -31.7 & $\ldots$ & 7.03 & 7.87 & 8.82 & 9.68 & 11.16 & 12.20 \\
\hline $\mathrm{CO}-\left(\mathrm{C}_{2}\right)_{2}$ & -38.1 & $\ldots$ & 3.26 & 6.77 & 7.67 & 8.48 & 9.62 & 9.85 \\
\hline $\mathrm{CO}^{-}\left(\mathrm{C}_{\mathrm{B}}\right)(\mathrm{C})$ & -30.9 & $\ldots$ & 5.68 & 6.92 & 7.70 & 8.36 & 9.39 & 9.76 \\
\hline $\mathrm{CO}-\left(\mathrm{C}_{4}\right)(\mathrm{H})$ & -34.6 & $\ldots$ & 6.40 & 7.72 & 8.91 & 9.85 & 11.49 & 12.09 \\
\hline $\mathrm{CO}-(\mathrm{C})_{2}$ & -31.4 & 15.01 & 5.59 & 6.32 & 7.09 & 7.76 & 8.89 & 9.61 \\
\hline $\mathrm{CO}-(\mathrm{C})(\mathrm{H})$ & -29.1 & 34.93 & 7.03 & 7.87 & 8.82 & 9.68 & 11.16 & 12.20 \\
\hline $\mathrm{CO}-(\mathrm{H})_{4}$ & -26.0 & 53.67 & 8.47 & 9.38 & 10.46 & 11.52 & 13.37 & 14.81 \\
\hline$O-\left(C_{\Perp}\right)(C O)$ & -32.5 & $\ldots$ & 2.06 & 2.70 & 3.11 & 3.42 & 3.88 & 4.18 \\
\hline $\mathrm{O}-(\mathrm{CO})_{2}$ & -50.9 & $\ldots$ & -0.41 & 1.78 & 3.20 & 4.00 & 5.13 & 5.85 \\
\hline $\mathrm{O}-(\mathrm{CO})(\mathrm{O})$ & -19.0 & $\ldots$ & 3.7 & 3.7 & 3.7 & 3.7 & 4.2 & 4.2 \\
\hline$O-(\mathrm{CO})\left(\mathrm{C}_{\alpha}\right)$ & -46.9 & $\ldots$ & 1.44 & 2.98 & 3.98 & 4.49 & 4.97 & 5.20 \\
\hline$\alpha-(C O)(C)$ & -44.3 & 8.39 & 3.90 & 3,61 & 4.19 & 4.62 & 4.99 & 4.82 \\
\hline $\mathrm{O}-(\mathrm{CO})(\mathrm{H})$ & -58.1 & 24.52 & 9.81 & 4.98 & 3.80 & 6.34 & 7.19 & 7.75 \\
\hline $0-(0)(C)$ & $(-4.5)$ & $(9.4)$ & $(3.7)$ & $(3.7)$ & $(3.7)$ & (3.7) & $(4.2)$ & $(4.2)$ \\
\hline $\mathrm{O}-(\mathrm{O})_{2}$ & $(-19.0)$ & $(9.4)$ & $(3.7)$ & $(3.7)$ & $(3.7)$ & $(3.7)$ & $(4.2)$ & $(4.2)$ \\
\hline $\mathrm{O}-(\mathrm{O})(\mathrm{H})$ & -16.27 & 27.85 & 5.17 & 5.79 & 6.28 & 6.66 & 7.15 & 7.51 \\
\hline $0-\left(C_{1}\right)_{2}$ & -32.8 & 10.1 & 3.4 & 3.7 & 3.7 & 3,8 & 4.4 & 4.6 \\
\hline$O-\left(C_{d}\right)(C)$ & -31.9 & 9.7 & 3.4 & 3.7 & 3.7 & 3.8 & 4.4 & 4.6 \\
\hline$O-\left(C_{0}\right)_{2}$ & -21.1 & $\ldots$ & 1.09 & 1.22 & 1.50 & 1.99 & 2.85 & 3.51 \\
\hline$O-\left(C_{n}\right)(C)$ & -22.6 & $\ldots$ & 3.4 & 3.7 & 3.7 & 3.8 & 4.4 & 4.6 \\
\hline $\mathrm{O}-\left(\mathrm{C}_{*}\right)(\mathrm{H})$ & -37.9 & 29.1 & 4.3 & 4.5 & 4.8 & 5.2 & 6.0 & 6.6 \\
\hline $\mathrm{O}-(\mathrm{C})_{2}$ & -23.7 & 8.68 & 3.4 & 3.7 & 3.7 & 3.8 & 4.4 & 4.6 \\
\hline $\mathrm{O}-(\mathrm{C})(\mathrm{H})$ & -37.9 & 29.07 & 4.33 & 4.45 & 4.82 & 5.23 & 6.02 & 6.61 \\
\hline C. $-(\mathrm{CO})(\mathrm{O})$ & 9.0 & $\ldots$ & 5.59 & 7.00 & 7.48 & 7.75 & 8.02 & 8.13 \\
\hline $\mathrm{C}_{d}-(\mathrm{CO})(\mathrm{C})$ & 9.4 & $\ldots$ & 3.73 & 4.48 & 5.02 & 5.40 & 5.95 & 6.37 \\
\hline $\mathrm{C}_{d}-(\mathrm{CO})(\mathrm{H})$ & 8.5 & $\ldots$ & 3.79 & 4.90 & 5.84 & 6.64 & 7.80 & 8.74 \\
\hline$C_{d}-(O)\left(C_{d}\right)$ & 8.9 & $\ldots$ & $(4,40)$ & $(5.37)$ & (5.93) & $(6.18)$ & $(6.50)$ & $(6.62)$ \\
\hline $\mathrm{C}_{\alpha}-(\mathrm{O})(\mathrm{C})$ & 10.3 & $\ldots$ & 4.10 & 4.61 & 4.99 & 5.26 & 5.80 & 6.08 \\
\hline $\mathrm{C}_{d}-(\mathrm{O})(\mathrm{H})$ & 8.6 & $\cdots$ & 4.16 & 5.03 & 5.81 & 6.50 & 7.65 & 8.45 \\
\hline $\mathrm{C}_{n}-(\mathrm{CO})$ & 9.7 & $\ldots$ & 2.67 & 3.14 & 3.68 & 4.15 & 4.96 & 5.44 \\
\hline$C_{0}-(\mathrm{O})$ & -0.9 & -10.2 & $y .9$ & 5.3 & 6.2 & 6.6 & 6.9 & 6.9 \\
\hline $\mathrm{C}-(\mathrm{CO})_{9}(\mathrm{H})_{2}$ & -7.6 & $\ldots$ & 5.60 & 7.05 & 8.39 & 9.68 & 11.58 & 12.87 \\
\hline $\mathrm{C}-(\mathrm{CO})\left(\mathrm{C}_{2}(\mathrm{H})\right.$ & -1.8 & -12.0 & 6.21 & 7.56 & 8.00 & 8.21 & 9.18 & 9.63 \\
\hline $\mathrm{C}-(\mathrm{CO})(\mathrm{C})(\mathrm{H})_{2}$ & -5.2 & 9.6 & 6.2 & 7.7 & 8.7 & 9.5 & 11.1 & 12.2 \\
\hline $\mathrm{C}-(\mathrm{CO})(\mathrm{C})$ & 1,6 & $\ldots$ & 5.07 & (i. 88 & 7.81 & 8.27 & 8.80 & 8.62 \\
\hline $\mathrm{C}-(\mathrm{CO})(\mathrm{H})$ & -10.1 & 90.41 & 6.19 & 7.84 & 9.40 & 10,79 & 13.02 & 14.77 \\
\hline $\mathrm{C}-(\mathrm{O})_{2}(\mathrm{C})_{2}$ & -18.6 & $\ldots$ & 1.59 & 3.95 & 6.20 & 7.39 & 7.62 & $8.4 K$ \\
\hline $\mathrm{C}-(\mathrm{O})_{2}(\mathrm{C})(\mathrm{H})$ & -16.3 & $\ldots$ & 5.06 & 7.28 & 9.03 & 9.41 & 10.31 & 10.75 \\
\hline $\mathrm{C}-(\mathrm{O})_{2}(\mathrm{H})_{2}$ & -15.1 & $\ldots$ & 2.83 & 5.06 & 7.52 & 9.12 & 10.32 & $11.2 !$ \\
\hline$\left.C-(O)\left(C_{b}\right)(H)\right)_{f}$ & -8.1 & 9.7 & $3.7 !$ & 6.27 & 8.28 & 9.79 & 11.79 & 13.20 \\
\hline $\mathrm{C}-(\mathrm{O})(\mathrm{C})(\mathrm{C})(\mathrm{H})$ & -6.118 & $\ldots$ & 5.14 & 7.30 & 8.83 & 9.43 & 10.23 & 10.6 \\
\hline $\mathrm{C}-(\mathrm{O})(\mathrm{C}$. $)(\mathrm{H})_{2}$ & -6.9 & $\ldots$ & 4.66 & 0.97 & 8.65 & 9.88 & 11.54 & 12.73 \\
\hline $\mathrm{C}-(\mathrm{O})(\mathrm{C})$ & -6.60 & -33.56 & 4.13 & (i. 19 & 7.25 & 7.70 & 8.20 & 8.24 \\
\hline $\mathrm{C}-(\mathrm{O})(\mathrm{C})_{2}(\mathrm{H})$ & -7.2 & -11.00 & 4.80 & i. 64 & 8.10 & 8.73 & 9.81 & 10.40 \\
\hline $\mathrm{C}-(\mathrm{O})(\mathrm{C})(\mathrm{H})_{2}$ & -8.1 & 9.8 & 4.99 & ii. 85 & 8.30 & 9.43 & 11.11 & 12.93 \\
\hline $\mathrm{C}-(\mathrm{O})(\mathrm{H})$ & -10.1 & 30.41 & 6.19 & $i .84$ & 9.40 & 10.79 & 13.03 & 14.77 \\
\hline
\end{tabular}


Table A-l Benson Group Contributione to Ideat-Gas Propertles: (Continued)

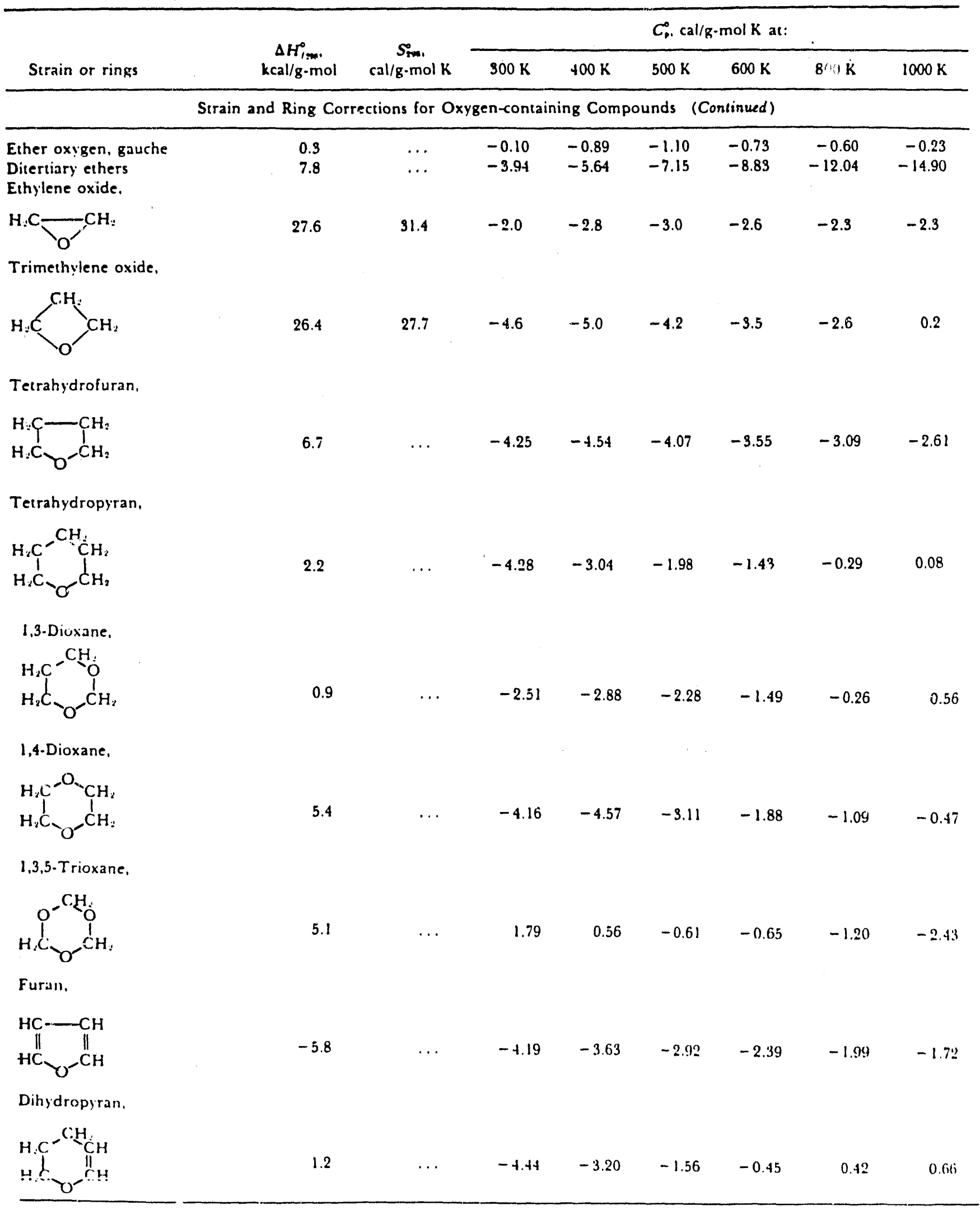




\begin{tabular}{|c|c|c|c|c|c|c|c|c|}
\hline \multirow[b]{2}{*}{ Strain or rings } & \multirow{2}{*}{$\begin{array}{c}\Delta H_{\text {/mon' }}^{\circ} \\
\mathrm{kcal} / \mathrm{g}-\mathrm{mol}\end{array}$} & \multirow{2}{*}{$\begin{array}{c}\text { Som, } \\
\mathrm{cal} / \mathrm{g}-\mathrm{mol} \mathrm{K}\end{array}$} & \multicolumn{6}{|c|}{$C_{\circ}^{\circ} \mathrm{cal} / \mathrm{g}-\mathrm{mol} \mathrm{K}$ at: } \\
\hline & & & $300 \mathrm{~K}$ & $400 \mathrm{~K}$ & $500 \mathrm{~K}$ & $600 \mathrm{~K}$ & $800 \mathrm{~K}$ & $1000 \mathrm{~K}$ \\
\hline
\end{tabular}

Strain and Ring Corrections for Oxygen-containing Compounds (Consinued)<smiles>O=C1CCCC1</smiles>

Cyclohexanone,<smiles>O=C1CCCCC1</smiles>

Succinic anhydride,<smiles>O=C1CCC(=O)O1</smiles>

Ciutaric anhydride.<smiles>O=C1CCCC(=O)O1</smiles>

Maleic anhydride,<smiles>O=C1C=CC(=O)O1</smiles>

\begin{tabular}{|c|c|c|c|c|c|c|c|c|}
\hline \multirow[b]{2}{*}{ Group" } & \multirow{2}{*}{$\begin{array}{c}\Delta H_{1, \mathrm{ma} \cdot}^{\circ} \\
\mathrm{kcal} / \mathrm{g} \cdot \mathrm{mol}\end{array}$} & \multirow{2}{*}{$\begin{array}{c}S_{\text {:ynn. }}^{\circ} \\
\mathrm{cal} / \mathrm{g} \cdot \mathrm{mol} \mathrm{K}\end{array}$} & \multicolumn{6}{|c|}{$(\therefore$ cal $/ g-m e s) k$ at: } \\
\hline & & & $300 \mathrm{~K}$ & $400 \mathrm{~K}$ & $500 \mathrm{~K}$ & $600 \mathrm{~K}$ & $800 \mathrm{~K}$ & $1000 \mathrm{~K}$ \\
\hline \multicolumn{9}{|c|}{ Nitrogen-containing Compounds } \\
\hline $\mathrm{C}-(\mathrm{N})(\mathrm{H})_{\mathrm{s}}$ & -10.08 & 30.41 & 6.19 & 7.84 & 9.40 & 10.79 & 13.02 & 14.77 \\
\hline $\mathrm{C}-(\mathrm{N})(\mathrm{C})(\mathrm{H})_{2}$ & -6.6 & 9.8 & 5.25 & 6.90 & 8.28 & 9.39 & 11.09 & 12.34 \\
\hline$\left(:-(N)(C)_{8}(H)\right.$ & -5.2 & -11.7 & 4.67 & 6.32 & 7.64 & 8.39 & 9.56 & 10.23 \\
\hline$C-(N)(C)$ & -9.2 & -34.1 & 4.35 & 6.16 & 7.31 & 7.91 & 8.49 & 8.50 \\
\hline$N-(C)(H)_{2}$ & 4.8 & 29.71 & 5.72 & 6.51 & 7.32 & 8.07 & 9.41 & 10.47 \\
\hline$\therefore-(C)_{2}(H)$ & 15.4 & 8.94 & 4.20 & 5.21 & 6.13 & 6.83 & 7.90 & 8.65 \\
\hline$N-(C)$ & 24.4 & -13.46 & 3.48 & 4.56 & 5.43 & 5.97 & 6.56 & 6.67 \\
\hline$N-(N)(H)_{2}$ & 11.4 & 29.13 & 6.10 & 7.38 & 8.43 & 9.27 & 10.54 & 11.52 \\
\hline$N-(N)(C)(H)$ & 20.9 & 9.61 & 4.82 & 5.8 & 6.5 & 7.0 & 7.8 & 8.3 \\
\hline$N-(N)(C)_{2}$ & 29.2 & -13.80 & 1.56 & 2.50 & 3.31 & 3.87 & 4.62 & $4 .(4)$ \\
\hline$N-(N)\left(C_{B}\right)(H)$ & 22.1 & $\ldots$ & 3.28 & 4.05 & 4.75 & 5.31 & 6.28 & 0.91 \\
\hline$N_{1}-(H)$ & (16.3) & $(12.3)$ & 2.95 & 4.58 & 6.45 & 7.71 & 9.13 & $9.9 !$ \\
\hline$N,-(C)$ & 21.3 & $\ldots$ & 2.48 & 3.34 & 3.95 & 4.29 & $4.5 !$ & 4.(i) \\
\hline$N,-\left(C_{n}\right)$ & 16.7 & $\ldots$ & 2.60 & 3.22 & 3.81 & 4.22 & $4.7 !$ & 5.12 \\
\hline$N_{A}-(H)$ & 25.1 & 26.8 & 4.38 & 4.89 & 5.44 & 5.94 & $6.7 i$ & 7.12 \\
\hline$N_{A}-(C)$ & 32.5 & 8.0 & 2.70 & 4.10 & 4.92 & 5.34 & $5.6 ?$ & 5.71 \\
\hline $\mathrm{N}-\left(\mathrm{C}_{n}\right)(\mathrm{H})_{2}$ & 4.8 & 29.71 & 5.72 & 6.51 & 7.32 & 8.07 & 9.41 & 10.17 \\
\hline$N-\left(C_{n}\right)(C)(H)$ & 14.9 & $\ldots$ & 3.82 & 4.89 & 5.71 & 6.28 & 7.19 & 7.73 \\
\hline$N-\left(C_{H}\right)(C)_{2}$ & 26.2 & $\ldots$ & 0.62 & 2.02 & 3.27 & 4.13 & 5.2 .3 & $5 . . i !$ \\
\hline$N-\left(C_{n}\right)_{y}(H)$ & 16.3 & $\ldots$ & 2.16 & 3.12 & 4.13 & 5.10 & $6.7 i$ & $7 . x$ \\
\hline$c_{n}-(N)$ & -0.5 & -9.69 & 3.95 & 5.21 & 5.94 & 6.32 & 6.5 .3 & (i) 1,1 \\
\hline$N_{A}-(N)$ & 23.0 & & 2.12 & 4.18 & $5.5 !$ & 6.77 & $6.86 i$ & $7.11 ?$ \\
\hline $\mathrm{COO}-(\mathrm{N})(\mathrm{H})$ & -29.6 & 34.93 & 7.03 & 7.87 & 8.82 & 9.68 & 11.16 & 1220 \\
\hline$(: O-(N)(C)$ & -32.8 & 16.2 & 5.37 & 6.17 & 7.07 & 7.66 & 9.62 & 11.11 \\
\hline$\therefore-(\bar{C} u n(i-i)$, & $-14 . y$ & 24.09 & 4.07 & 5.74 & 7.13 & 8.29 & 9.96 & 11.28 \\
\hline$N-(C, O)(C)(H)$ & -4.4 & 3.9 & 3.87 & 5.08 & 5.95 & 6.76 & 6.87 & 6.94 \\
\hline$N-(C, O)(C)$, & 4.7 & $\ldots$ & 1.83 & 3.79 & 5.24 & 6.19 & 7.11 & 712 \\
\hline $\mathrm{N}-(\mathrm{CO})\left(\mathrm{C}_{n}\right)(\mathrm{H})$ & 0.4 & $\ldots$ & 3.03 & 3.91 & $4.6 n$ & 5.58 & 6.23 & (i) 31 \\
\hline
\end{tabular}


TABLE A-1 Benson Group Contributions to Ideal-gas Properties' (Continued)

\begin{tabular}{|c|c|c|c|c|c|c|c|c|}
\hline \multirow[b]{2}{*}{ Group" } & \multirow{2}{*}{$\underset{\mathrm{kcal} / \mathrm{g} \cdot \mathrm{mol}}{\Delta H_{i}^{*}}$} & \multirow{2}{*}{$\stackrel{S_{i m .}}{\mathrm{cal} / \mathrm{g} \cdot \mathrm{mol} \mathrm{K}}$} & \multicolumn{6}{|c|}{ 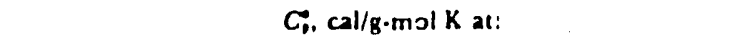 } \\
\hline & & & $300 \mathrm{~K}$ & $400 \mathrm{~K}$ & $500 \mathrm{~K}$ & $600 \mathrm{~K}$ & $800 \mathrm{~K}$ & $1000 \mathrm{~K}$ \\
\hline \multicolumn{9}{|c|}{ Nitrogen-concaining Compounds (Consinued) } \\
\hline $\mathrm{N}-(\mathrm{CO})_{2}(\mathrm{H})$ & -18.5 & $\ldots$ & 3.59 & 5.54 & 6.70 & 7.39 & 7.95 & 8.19 \\
\hline $\mathrm{N}-(\mathrm{CO})_{2}(\mathrm{C})$ & -5.9 & $\ldots$ & 1.07 & 3.10 & 4.31 & 5.00 & 5.48 & 6.47 \\
\hline $\mathrm{N}-(\mathrm{CO})_{2}\left(\mathrm{C}_{2}\right)$ & -0.5 & $\ldots$ & 0.98 & 3.06 & 4.23 & 4.85 & 3.28 & 5.29 \\
\hline $\mathrm{C}-\left(\mathrm{CN}^{\prime}\right)(\mathrm{C})(\mathrm{H})_{2}$ & 22.5 & 40.20 & 11.10 & 19.40 & 15.50 & 17.20 & 19.7 & 21.30 \\
\hline $\mathrm{C}-\left(\mathrm{CN}^{\prime}\right)(\mathrm{C})_{7}(\mathrm{H})$ & 25.8 & 19.80 & 11.00 & 12.70 & 14.10 & 15.40 & 17.30 & 18.60 \\
\hline$C-(C N)(C)_{2}$ & 29.0 & -2.80 & 8.65 & 11.16 & 12.89 & 14.05 & $|5.5|$ & 16.19 \\
\hline$C-(C . N)_{2}(C)_{2}$ & $\ldots$ & 28.40 & 14.72 & 17.79 & 20.00 & 21.61 & 23.78 & 24.96 \\
\hline$C_{d}-\left(C_{N}\right)(H)$ & 37.4 & 36.58 & 9.80 & 11.70 & 19.30 & 14.50 & 16.30 & 17.30 \\
\hline C. $-(C . N)(C)$ & 39.15 & 15.91 & 9.74 & 11.28 & 12.48 & 13.26 & 14.45 & 14.93 \\
\hline C. $-(C . N)$, & 84.1 & $\ldots$ & 13.60 & 16.55 & 18.68 & 20.25 & 22.34 & 23.59 \\
\hline $\mathrm{C}_{4}-(\mathrm{NO})_{2}(\mathrm{H})$ & $\ldots$ & 44.4 & 12.3 & 15.1 & 17.4 & 19.2 & 21.6 & 23.2 \\
\hline$C_{0}-(C N)$ & 35.8 & 20.50 & 9.8 & 11.2 & 12.3 & 13.1 & 14.2 & 14.9 \\
\hline$C_{1}-(C, N)$ & 69.8 & 35.40 & 10.30 & 11.30 & 12.10 & 12.70 & 13.60 & 14.30 \\
\hline $\mathrm{C}-(\mathrm{NO}),(\mathrm{C})(\mathrm{H})_{2}$ & -15.1 & 48.4 & 12.39 & 15.82 & 18.52 & 20.66 & 23.79 & 25.90 \\
\hline $\mathrm{C}-\left(\mathrm{NO}_{1}\right)(\mathrm{C})_{8}(\mathrm{H})$ & -15.8 & 26.9 & 11.99 & 15.21 & 17.72 & 19.61 & 22.18 & 29.70 \\
\hline $\mathrm{C}-\left(\mathrm{NO}_{2}\right)(\mathrm{C})$ & $\ldots$ & 3.9 & 9.89 & 13.34 & 15.86 & 17.62 & 19.41 & 20.86 \\
\hline $\mathrm{C}-\left(\mathrm{NO}_{2}\right)_{2}(\mathrm{C})(\mathrm{H})$ & -14.9 & $\ldots$ & 17.32 & 22.82 & 27.07 & 30.21 & 34.35 & 96.83 \\
\hline$O-(\mathrm{NO})(\mathrm{C})$ & -5.9 & 41.9 & 9.10 & 10.30 & 11.2 & 12.0 & 13.3 & 18.9 \\
\hline \multirow[t]{2}{*}{$\mathrm{O}-\left(\mathrm{NO}_{3}\right)(\mathrm{C})$} & -19.4 & 48.50 & 9.54 & 11.54 & 19.26 & 15.60 & 16.39 & 17.38 \\
\hline & & & \multicolumn{6}{|c|}{$C_{:, \mathrm{cal} / \mathrm{g}-\mathrm{mol} \mathrm{K} \text { at: }}$} \\
\hline Ring & $\mathrm{kcal} / \mathrm{g}-\mathrm{mol}$ & $\mathrm{cal} / \mathrm{g} \cdot \mathrm{mol} \mathrm{K}$ & $300 \mathrm{~K}$ & $400 \mathrm{~K}$ & $500 \mathrm{~K}$ & $600 \mathrm{~K}$ & $800 \mathrm{~K}$ & $1000 \mathrm{~K}$ \\
\hline
\end{tabular}

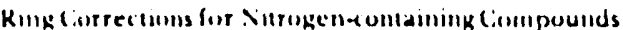

Eihyleneimine.<smiles>C1CN1</smiles>

Azetidine<smiles>C1CNC1</smiles>

Pyrrolidine,<smiles>C1CCNC1</smiles>

6.8 26.7 $-6.17-5.58$ $-4.80$ $-4.00$ $-2.8$

Piperieline.<smiles>[C]1CCCCC1</smiles>
0.37 1.08 1.56 1.71

$\mathrm{C}_{\mathrm{n}} \mathrm{H}_{1}, \mathrm{~N}: \mathrm{S}$<smiles>C1CN2CN3CCC2C1C3</smiles>
$\begin{array}{llllll}-9.44 & -8.70 & -7.00 & -5.36 & -3.21 & -1.84\end{array}$

Succinimide.<smiles></smiles> 
TABLE A-1Benson Group Contributions to Ideal-Gas Properties* (Continued)

\begin{tabular}{|c|c|c|c|c|c|c|c|c|c|}
\hline \multirow[b]{2}{*}{ Group } & & \multirow{2}{*}{$\begin{array}{c}\Delta H_{\text {im. }}^{\circ} \\
\mathrm{kcal} / \mathrm{g} \cdot \mathrm{mol}\end{array}$} & \multirow{2}{*}{$\underset{\mathrm{cal} / \mathrm{g}-\mathrm{mol} \mathrm{K}}{\text { Sow }^{\prime}}$} & \multicolumn{6}{|c|}{$C_{0}^{\circ}, \mathrm{cal} / \mathrm{g}-\mathrm{mol} \mathrm{K}$ at: } \\
\hline & & & & $300 \mathrm{~K}$ & $400 \mathrm{~K}$ & $500 \mathrm{~K}$ & $600 \mathrm{~K}$ & $800 \mathrm{~K}$ & $1000 \mathrm{~K}$ \\
\hline \multicolumn{10}{|c|}{ Halogen Groups } \\
\hline$C-(F),(C)$ & & -158.4 & 42.5 & 12.7 & 15.0 & 16.4 & 17.9 & 19.3 & 20.0 \\
\hline$C-(F)_{2}(H)(C)$ & & -109.3 & 39.1 & 9.9 & 12.0 & 13.7 & 15.1 & 16.7 & 17.8 \\
\hline $\mathrm{C}-(\mathrm{F})(\mathrm{H})_{2}(\mathrm{C})$ & & -51.5 & 35.4 & 8.1 & 10.0 & 12.0 & 13.0 & 15.2 & 16.6 \\
\hline$C-(F)_{2}(C)_{2}$ & & -97.0 & 17.8 & 9.9 & 11.8 & 13.5 & 14.4 & 16.1 & 16.6 \\
\hline$C-\langle F)(H)(C)_{2}$ & & -49.0 & 14.0 & 7.30 & 9.04 & 10.47 & 11.56 & 13.10 & 14.01 \\
\hline$C-(F)(C)$ & & -48.5 & $\ldots$ & 6.80 & 8.86 & 10.20 & 11.16 & 12.43 & 12.72 \\
\hline$C-(F)_{2}(C l)(C)$ & . & -106.3 & 40.5 & 13.7 & 16.1 & 17.5 & 18.6 & 19.8 & 20.4 \\
\hline$C-(C, I),(C)$ & & -20.7 & 50.4 & 16.3 & 18.0 & 19.1 & 19.8 & 20.6 & 21.0 \\
\hline $\mathrm{C}-(\mathrm{Cl})_{2}(\mathrm{H})(\mathrm{C})$ & & $(-18.9)$ & 43.7 & 12.1 & 14.0 & 15.4 & 16.5 & 17.9 & 18.7 \\
\hline $\mathrm{C}-(\mathrm{Cl})(\mathrm{H})_{2}(\mathrm{C})$ & & -16.5 & 37.8 & 8.9 & 10.7 & 12.3 & 13.4 & 15.3 & 16.7 \\
\hline$C-(C I)_{2}(C)_{2}$ & & -22.0 & 22.4 & 12.2 & 14.88 & 15.95 & 16.48 & 16.96 & 17.02 \\
\hline $\mathrm{C}-(\mathrm{Cl})(\mathrm{H})(\mathrm{C})_{2}$ & & -14.8 & 17.6 & 9.0 & 9.9 & 10.5 & 11.2 & 13.9 & 14.6 \\
\hline $\mathrm{C}-(\mathrm{Cl})(\mathrm{C})_{3}$ & & -12.8 & -5.4 & 9.3 & 10.5 & $11: 0$ & 11.3 & 12.4 & 12.7 \\
\hline $\mathrm{C}-(\mathrm{Br}),(\mathrm{C})$ & & $\ldots$ & 55.7 & 16.7 & 18.0 & 18.8 & 19.4 & 19.9 & 20.3 \\
\hline $\mathrm{C}-(\mathrm{Br})(\mathrm{H}),(\mathrm{C})$ & & -5.4 & 40.8 & 9.1 & 11.0 & 12.6 & 13.7 & 15.5 & 16.8 \\
\hline $\mathrm{C}-(\mathrm{Br})(\mathrm{H})(\mathrm{C})_{2}$ & & -3.4 & $\ldots$ & 8.93 & 10.66 & 11.96 & 12.84 & 14.05 & 14.72 \\
\hline $\mathrm{C}-(\mathrm{Br})(\mathrm{C})$ & & -0.4 & -2.0 & 9.3 & 11.0 & 11.5 & 12.3 & 13.3 & 13.3 \\
\hline$C-(I)(H)_{,}(C)$ & & 8.0 & 43.0 & 9.2 & 11.0 & 12.9 & 13.9 & 15.8 & 17.2 \\
\hline$\left(:-(1)(H)(C)_{z}\right.$ & & 10.5 & 21.3 & 9.2 & 10.9 & 12.2 & 13.0 & 14.2 & 14.8 \\
\hline$\left(:-(I)(C)\left(C_{A}\right)(H)\right.$ & & 13.32 & $\ldots$ & 8.13 & 10.02 & 11.82 & 12.6 & 14.0 & 14.9 \\
\hline$C_{C}-(I)\left(C_{d}\right)(H)_{2}$ & & 8.19 & $\ldots$ & 8.82 & 10.91 & 12.97 & 14.04 & 15.95 & 17.34 \\
\hline$C-(1)(C)$ & & 130 & 0 & 9.83 & 11.75 & 12.92 & 13.45 & 13.79 & 13.60 \\
\hline$\left(--(c)(1)\left(s_{1}\right)(l)\right)(c)$ & & $\ldots$ & 45.7 & 12.4 & 14.1 & $1 j .6$ & $11 i .3$ & 17.9 & 19.0 \\
\hline$x-(f):(c)$ & & -7.8 & $\ldots$ & 8.25 & 10.13 & 11.52 & 12.80 & 14.37 & 14.98 \\
\hline$(\mathrm{C}-(\mathrm{CI})(\mathrm{C})(\mathrm{O})(\mathrm{H})$ & & -21.6 & 15 & 9.85 & 10.41 & 11.05 & 11.57 & 12.45 & 13.14 \\
\hline $\mathrm{C}-(\mathrm{I})_{2}(\mathrm{C})(\mathrm{H})$ & & $(26.0)$ & $(54.6)$ & 12.69 & 14.78 & 16.21 & 17.12 & 18.31 & 19.03 \\
\hline $\mathrm{C}-(\mathrm{I})(\mathrm{O})(\mathrm{H})_{2}$ & & 3.8 & 40.7 & 8.22 & 10.49 & 12.23 & 13.55 & 15.35 & 16.57 \\
\hline$C_{d}-(F)_{2}$ & & -77.5 & 97.3 & 9.7 & 11.0 & 12.0 & 12.7 & 13.8 & 14.5 \\
\hline$C_{0}-(\mathrm{Cl})_{2}$ & & -1.8 & 42.1 & 11.4 & 12.5 & 13.3 & 13.9 & 14.6 & 15.0 \\
\hline $\mathrm{C}_{0}-(\mathrm{Br})_{2}$ & & $\ldots$ & 47.6 & 12.3 & 13.2 & 13.9 & 14.3 & 14.9 & 15.2 \\
\hline$C_{d}-(F)(C l)$ & & $\ldots$ & 39.8 & 10.3 & 11.7 & 12.6 & 13.3 & 14.2 & 14.7 \\
\hline$C_{d}-(F)(B r)$ & & $\ldots$ & 42.5 & 10.8 & 12.0 & 12.8 & 13.5 & 14.3 & 14.7 \\
\hline$C_{c}-(\mathrm{Cl})(\mathrm{Br})$ & & $\ldots$ & 45.1 & 12.1 & 12.7 & 13.5 & 14.1 & 14.7 & 14.7 \\
\hline$C_{d}-(F)(H)$ & & -37.6 & 32.8 & 6.8 & 8.4 & 9.5 & 10.5 & 11.8 & 12.7 \\
\hline $\mathrm{C}_{d}-(\mathrm{Cl})(\mathrm{H})$ & & -1.2 & 35.4 & 7.9 & 9.2 & 10.3 & 11.2 & 12.3 & 13.1 \\
\hline$\left(i_{a}-\left(\mathrm{B}_{r}\right)(H)\right.$ & & 11.0 & 38.3 & 8.1 & 9.5 & 10.6 & 11.4 & 12.4 & 13.2 \\
\hline$C_{0}-(1)(H)$ & & 24.5 & 40.5 & 8.8 & 10.0 & 10.9 & 11.6 & 12.6 & 13.3 \\
\hline$\left(C_{4}-(C)(C)\right.$ & & -2.1 & 15.0 & 8.0 & 8.4 & 8.5 & 9.0 & 9.2 & 9.4 \\
\hline$C_{4}-(C)(1)$ & & 23.6 & $\ldots$ & 8.9 & 9.2 & 9.1 & 9.4 & 9.5 & 9.6 \\
\hline$C_{4}-\left(C_{0}\right)\left(C_{1}\right)$ & & -3.56 & $\ldots$ & 8.3 & 9.2 & 9.4 & 9.9 & 9.9 & 9.9 \\
\hline$\left(C_{d}-\left(C_{d}\right)(1)\right.$ & & 22.14 & $\ldots$ & 9.2 & 9.9 & 10.0 & 10.3 & 10.3 & 10.1 \\
\hline $\mathrm{C}_{1}-(\mathrm{Cl})$ & & $\ldots$ & 33.4 & 7.9 & 8.4 & 8.7 & 9.0 & 9.4 & $9 . i$ \\
\hline $\mathrm{C}_{1}-(\mathrm{Br})$ & & $\ldots$ & 36.1 & 8.3 & 8.7 & 9.0 & 9.2 & 9.5 & 9.7 \\
\hline$C_{1}-$ (I) & & $\ldots$ & 37.9 & 8.4 & 8.8 & 9.1 & 9.3 & 9.6 & 9.8 \\
\hline$C_{n}-(F)$ & & -42.8 & 16.1 & 6.3 & 7.6 & 8.5 & 9.1 & 9.8 & 10.2 \\
\hline$C_{0}-(\mathrm{Cl})$ & ' & -3.8 & 18.9 & 7.4 & 8.4 & 9.2 & 9.7 & 10.2 & 104 \\
\hline $\mathrm{C}_{n}-(\mathrm{Br})$ & & 10.7 & 21.6 & 7.8 & 8.7 & 9.4 & 9.9 & 10.3 & 10.5 \\
\hline$C_{n}-(1)$ & & 24.0 & 23.7 & 8.0 & 8.9 & 9.6 & 9.9 & 10.3 & 10.5 \\
\hline$\left(-\left(C_{a}\right)(F)\right.$ & & -162.7 & 42.8 & 12.5 & 15.3 & 17.2 & 18.5 & 20.1 & 21.11 \\
\hline $\mathrm{C}-\left(\mathrm{C}_{2}\right)(\mathrm{Br})(\mathrm{H})_{2}$ & & -6.9 & $\ldots$ & 9.29 & 11.10 & 12.47 & 13.69 & 15.59 & 1671 \\
\hline $\mathrm{C}-\left(\mathrm{C}_{n}\right)(1)(\mathrm{H})_{2}$ & & 8.4 & $\ldots$ & 9.78 & 11.56 & 12.90 & 14.08 & 15.88 & 16.41 \\
\hline $\mathrm{C}-(\mathrm{Cl})_{2}(\mathrm{CO})(\mathrm{H})$ & & -17.8 & $\ldots$ & 12.8 & 14.75 & 15.85 & 16.65 & 17.93 & $18.5 i$ \\
\hline $\mathrm{C}-(\mathrm{Cl}),(\mathrm{CO})$ & & -19.6 & $\ldots$ & 17.0 & 18.75 & 19.55 & 19.95 & 20.63 & $20 \mathrm{kit}$ \\
\hline $\mathrm{CO}-(\mathrm{Cl})(\mathrm{C})$ & & -30.2 & $\ldots$ & 8.87 & 9.44 & 10.24 & 11.08 & 12.53 & 13.59 \\
\hline
\end{tabular}


TABLE A-1 Benson Group Contributions to ldeatGas Properties: (Continued)

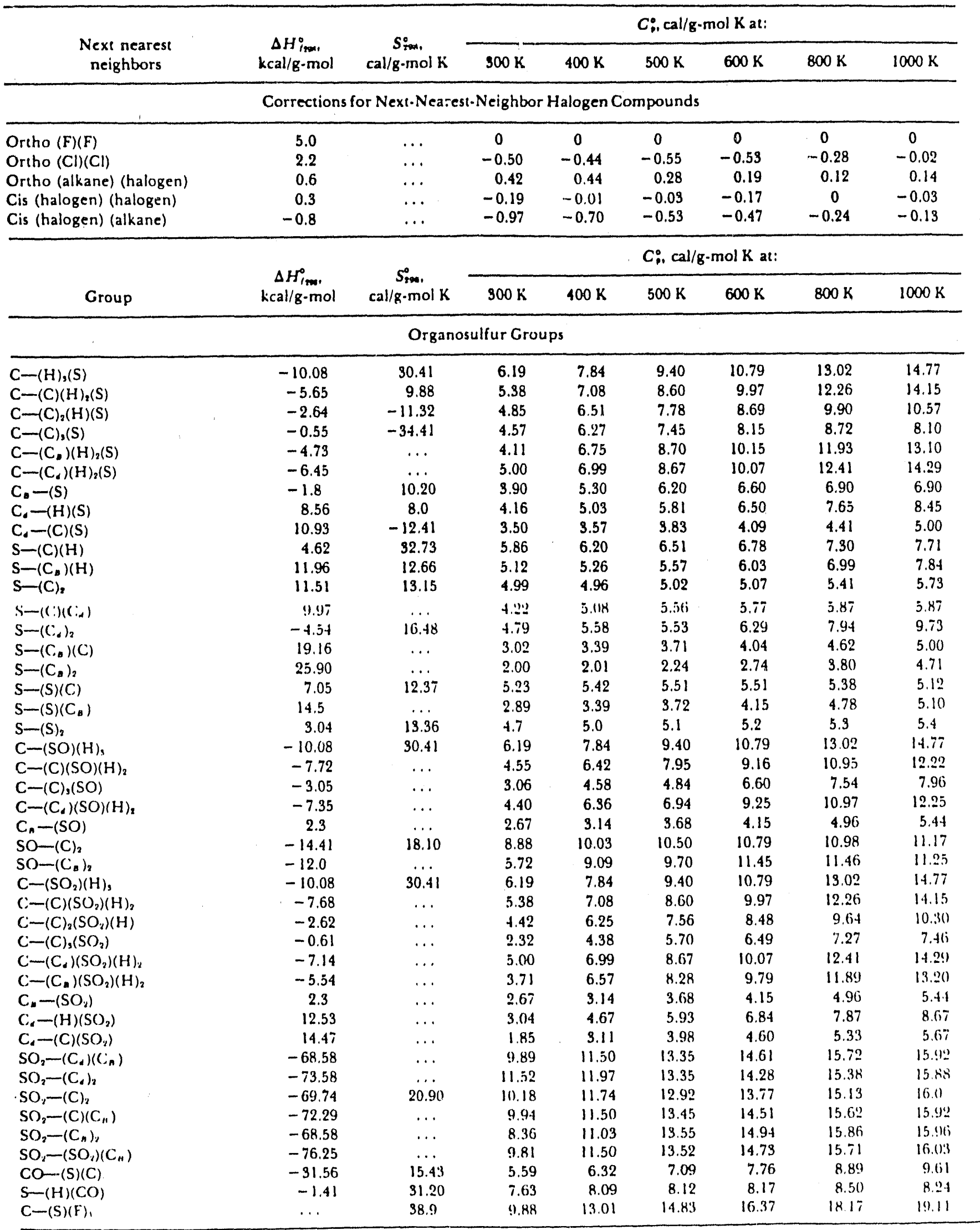




\begin{tabular}{|c|c|c|c|c|c|c|c|c|}
\hline \multirow[b]{2}{*}{ Group } & \multirow{2}{*}{$\begin{array}{c}\Delta H_{/ \mathrm{man}}^{\circ} \\
\mathrm{kcal} / \mathrm{g}-\mathrm{mol}\end{array}$} & \multirow{2}{*}{$\underset{\mathrm{cal} / \mathrm{g} \cdot \mathrm{mol} \mathrm{K}}{S_{\mathrm{row}}}$} & \multicolumn{6}{|c|}{$C_{b}^{\circ} \mathrm{cal} / \mathrm{g}-\mathrm{mol} \mathrm{K}$ at: } \\
\hline & & & $300 \mathrm{~K}$ & $400 \mathrm{~K}$ & $500 \mathrm{~K}$ & $600 \mathrm{~K}$ & $800 \mathrm{~K}$ & $1000 \mathrm{~K}$ \\
\hline $\operatorname{CS}-(N)_{x}$ & -31.56 & 15.43 & 5.59 & 6.32 & 7.09 & 7.76 & 8.89 & 9.61 \\
\hline$N-(C S)(H)_{2}$ & 12.78 & 29.19 & 6.07 & 7.28 & 8.18 & 8.91 & 10.09 & 10.98 \\
\hline$S-(S)(N)$ & -4.90 & $\ldots$ & 3.7 & 3.7 & 3.7 & 3.7 & 4.2 & 4.2 \\
\hline $\mathrm{N}-(\mathrm{S})(\mathrm{C})_{2}$ & 29.9 & $\ldots$ & 3.97 & 5.17 & 6.21 & 6.94 & 7.39 & 9.24 \\
\hline $\mathrm{SO}-(\mathrm{N})_{2}$ & -91.56 & $\ldots$ & 5.59 & 6.32 & 7.09 & 7.76 & 8.89 & 9.61 \\
\hline $\mathrm{N}-(\mathrm{SO})(\mathrm{C})_{2}$ & 16.0 & $\ldots$ & 4.20 & 5.88 & 6.12 & 6.53 & 6.83 & 8.34 \\
\hline $\mathrm{SO}_{2}-(\mathrm{N})_{2}$ & -31.56 & $\ldots$ & 5.59 & 6.32 & 7.09 & 7.76 & 8.89 & 9.61 \\
\hline $\mathrm{N}-\left(\mathrm{SO}_{2}(\mathrm{C})_{2}\right.$ & -20.4 & $\ldots$ & 6.02 & 6.95 & 7.54 & 8.23 & 9.03 & 9.19 \\
\hline
\end{tabular}

$C_{\text {. }}^{\circ} \mathrm{cal} / \mathrm{g} \cdot \mathrm{mol} \mathrm{K}$ at:

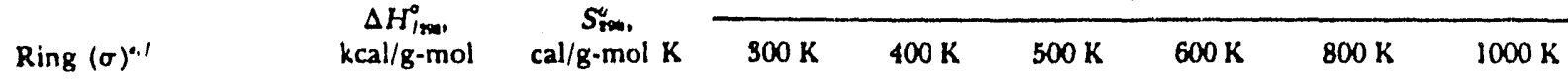

Ring Corrections for Sulfur-containing Compounds

Thiirane (2),<smiles>C1CS1</smiles>

Trimethylene sulfide (2),<smiles>C1CSC1</smiles>

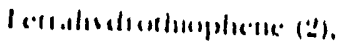

$$
\text { H. }
$$

Thiacyclohexane (2),<smiles>C1CCSCC1</smiles>

Thiacycloheptane (2),<smiles>C1CCSCC1</smiles>

3.Thiocyclopentene (2),

$$
\text { H.C.S }-\mathrm{CH}_{2}
$$

2-Thiocyclopentene (1),

$$
\text { HC: }
$$

$\mathrm{C}_{4} \mathrm{H}_{6} \mathrm{SO}_{4}(2)$,<smiles>O=S1(=O)CC=CC1</smiles>

5.07

$$
-4.24
$$$$
-4.23
$$$$
-4.18
$$$$
-4.80
$$$$
-5.9 \mathrm{ki}
$$

4.61 
TABLE A-1 Benson Group Contributions to Ideatgas Properties' (Continued)

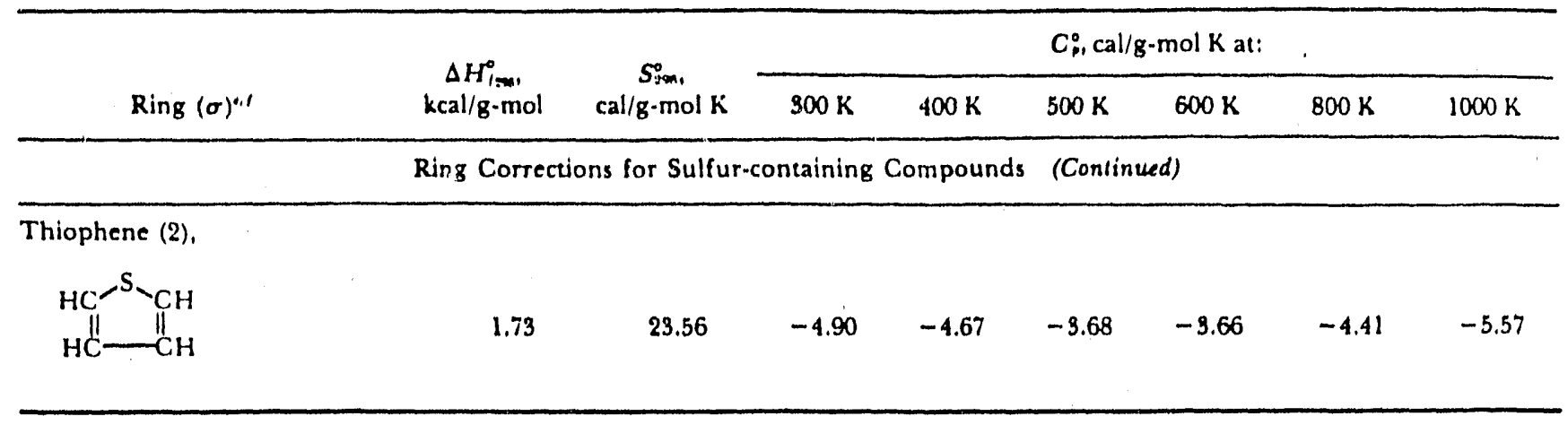

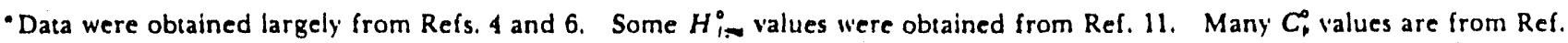
20. Grateful acknowledgment is extended to Shell Development Co., Bellaire Research Center, and particularly to Dr. P. Chueh, for supplying missing values as well as additional contributions. Finally, Dr. S. W. Benson provided an up-to-date errata list that showed recent modifications of the original tables.

'C. represents a carbon atom that is joined to another carbon atom by a double bond. It is considered divalent. For example,

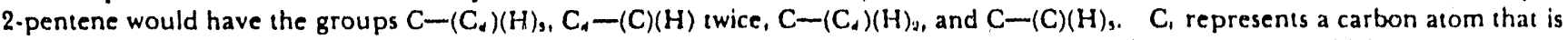
joined to another carbon atom by a triple bond. It is considered monovalent. For example, propyne would have the groups $\mathrm{C}_{1}-(\mathrm{H}), \mathrm{C}_{1}-(\mathrm{C})$, and $\mathrm{C}-\left(\mathrm{C}_{1}\right)\left(\mathrm{H}_{3}\right)$. $\mathrm{C}_{\mathrm{n}}$ represents a carbon atom in an aromatic ring. It is considered monovalent. For example, peethyl toluene would have the groups $\mathrm{C}-(\mathrm{C})(\mathrm{H})_{2}, \mathrm{C}-\left(\mathrm{C}_{a}\right)(\mathrm{C})(\mathrm{H})_{2}, \mathrm{C}-\left(\mathrm{C}_{a}\right)(\mathrm{H}), \mathrm{C}_{\mathrm{a}}-(\mathrm{C})$ twice, and $\mathrm{C}_{\mathrm{n}}-(\mathrm{H})$ four times. $\mathrm{C}_{\text {a }}$ represents the allene group, $>\mathrm{C}=\mathrm{C}=\mathrm{C}<$; the end carbons are treated as normal $\mathrm{C}_{d}$ atoms. For example, 1,2-butadiene would have

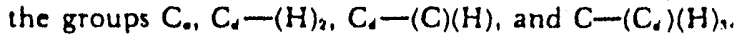

'When one of the groups is $t$-butyl, the cis correction $=4.0$; when both are 1 -butyl, the cis correction $=10.0$; and when there are two cis corrections around one double bond, the total correction $=3.0$.

- Value is 1.2 for but-2-ene but zero for other dienes and 0.6 for trienes.

'The number in parentheses beside each ring is the sy'mmetry number.

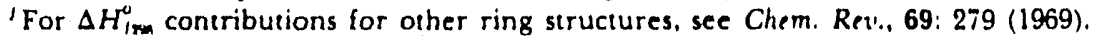

- $N_{1}$ represents a double-bonded nitrogen in imines; $N_{1}-\left(C_{n}\right)$ represents a pyridine nitrogen. $N_{A}$ represents a double-bonded nitrogen in azo compounds. For ortho or para substitution in pyrittine add $-1.5 \mathrm{kcal} / \mathrm{g} \cdot \mathrm{mol}$ per group to $\Delta H_{1: \mathrm{m}}^{\circ}$. 
Example: Estimation of $\Delta H_{f 298}^{\circ}$ and $\Delta S_{298}^{\circ}$ for vanillin

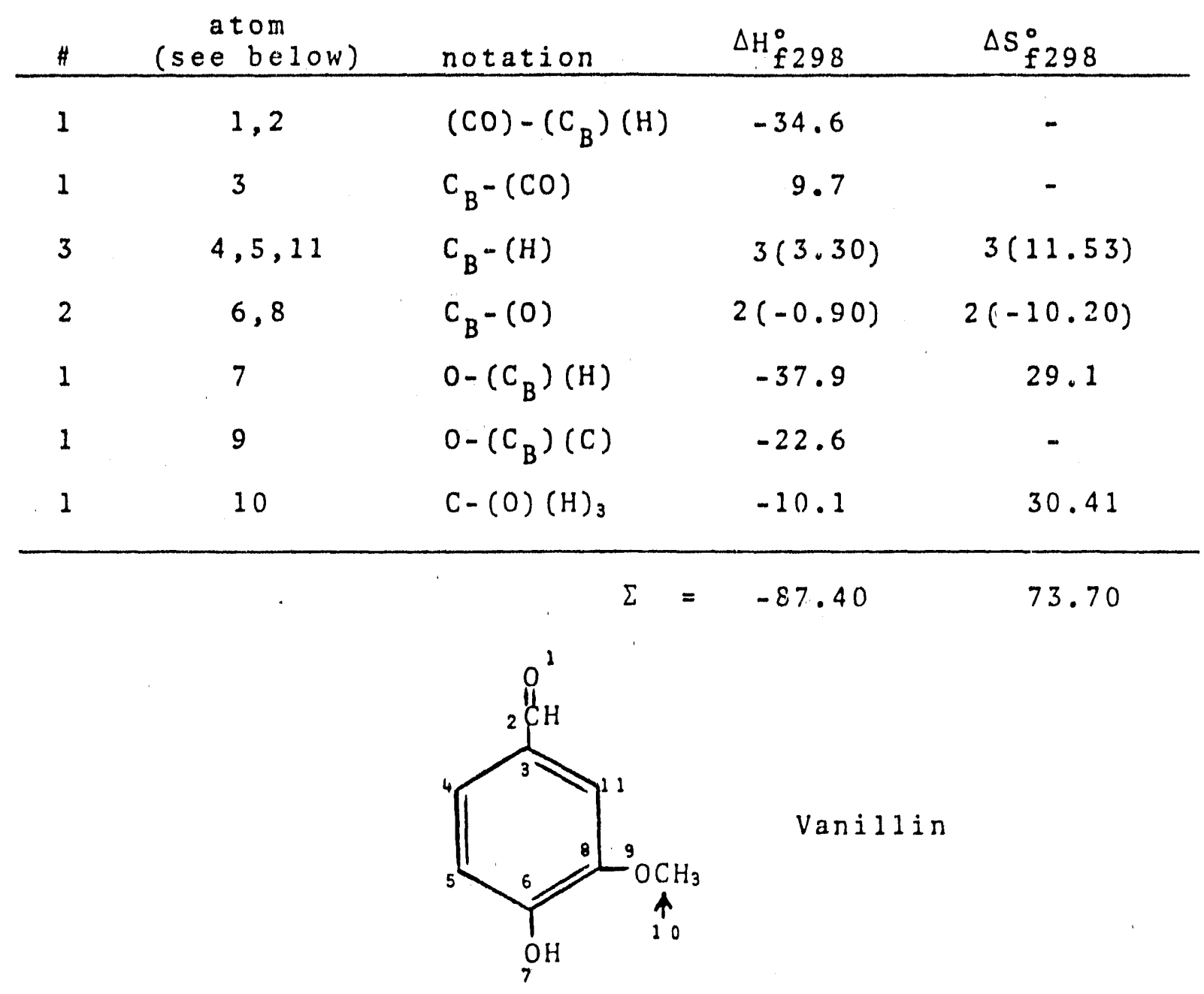




\section{TABLE B-1 - RECOMMEXDED CATALYSTS TOR THE ENDOTHERMIC CYCLIZATION-ADDITION REACTIONS}

CHEM REACTIOH:

Resction type:

Recoma. Cotelyst

1) Pt on Alumina

\author{
$\mathrm{nC} 6 \mathrm{H}_{14} \longrightarrow \mathrm{CGH6}$. \\ aromatization (cyclization+dehydration) \\ comments
}

ref

Proven to be the best aromatization catalyst. The hydroxy- (1),(3), (4) lation state of alumina tias a determining influence on the particle size of platinum crystallites, and it cen also effect selectivity and the rate of producion of arenes. Possible side products: iC6, and 1,3,5 trans Hexatriene.

2) Pt an elumina \& A possible cendidate; mure frequently used for dehydrosilics cyclization of alkylaromatics.

3) HSZM Zeolite characterized as $5 i 02 / A 1203=21$, surface area of $300 \mathrm{sq}-\mathrm{m} / \mathrm{gr}$, and restriction coefficient of 12

CHEM REACTION:

Resction type:

Recomm. Catalyst

$$
\begin{gathered}
\mathrm{nC} 6 \mathrm{H} 14+\mathrm{CH} 3 \mathrm{OH} \\
\text { Dehydrocyclization-addition }
\end{gathered}
$$

1) $\mathrm{Mg}-\mathrm{Cu}$ Good yields have been obtained when used for alkylation of mono substituted arenes with methianol.

(6)

2) X,Y Type Zeolites , HY Zeolite

comments

An alkylation catal yst tested in the lahoratories for corverting phenol to O,P cresols, which may also be ce; . ble of promoting dehydrocyclization

3) $\mathrm{Cr}$ 203-A1203 A boluene selective catalyst when used for cyclization of higher hydrocarbons. 
CHEM REACTION:

Reaction type:

Recoma. Cotolyst
$\mathrm{NC} 6 \mathrm{H} 14+\mathrm{CH} 3 \mathrm{OH}$ $\mathrm{C} 6 \mathrm{H} 5 \mathrm{OH}$

Dehydrocyclization-addition

\section{comasats}

ror

(9)

1) Pt on A1203, Cobolt(III) olkylperoxy complexes ore proven to be followed by Co(III) selective catalysts for hydroxylation of arenes

2) Pt on A1203,

followed by mol ybdo. Second step does not involve a powdered catal yst, however vanadophospharic acid it involves a transition metal complex which may be activated whiten introduced to UY photons.

CHEM REACTIOH:

Reaction type:

Recomm. Catalyst

We just might get luck! !!!

1) $P \operatorname{ton} A 1203$
$\mathrm{NC6H14}+\mathrm{NH}_{3} \longrightarrow \mathrm{CEH} 5 \mathrm{NH} 2$

Dehydrocyclization-sddition

comments

rer
CHEM REACTIOH:

Reaction type:

Recomm. Catslyst

1) Pt on Al203, In the presence of hydroxyl ions, addition of the the followed by $\mathrm{Fe}(11)$ second hydroxyl ion to the phenol ring is promoted

2) Pt on Al203, Method of preparation of the cotaiyst is further discussed followed by Yanadiun in the article reierenced. ror 
CHEM REACTION:

Reaction type:

Recomas. Cotelyst
$\mathrm{C} 6 \mathrm{H} 5 \mathrm{CH} 3+\mathrm{H} 2 \mathrm{O} \longrightarrow \mathrm{C} 6 \mathrm{H} 4(\mathrm{OH})\langle\mathrm{CH} 3\rangle$

Hydroxylation

comasats

1) $\mathrm{Fe}(11)$

This is the reation l om excrited atout!"

(10)

This type of resction is carried out in the presence of hydrogen pe roxide, $\mathrm{H} 2 \mathrm{O2}$, catal yzed by $\mathrm{Fe}(\mathrm{II})$. However, the cotalyst will constantiy be oxidized to Fe(III) while the reaction is in progress.

Gaod neli's: The UY radiation reduces the catalytically inactive Fe(III) produced, to $\mathrm{Fe}(11)$ during the regction, the refore continuously producing the desired catal yst. It will also bregk up the woter molecules, present in the feed to $\mathrm{H}+$ and $\mathrm{OH}$ - Hyrirogen ions will promote the reduction of Fe(III) fons and the hydroxyl tons will serve ss a substitute for the $\mathrm{H} 2 \mathrm{O} 2$ of the fenton reegent.

\section{REFERENCES}

[1] Dautzenberg, F.M., and Platteuw, J.C. J. catal 19,41 (1970).

[2] Paal, z. Advances in catalysis 29, 273-329 (1980).

[3] Csicsery, S.M. Advances in catalys is 28, 293-319 (1979).

[4] Gault, F.G. Advances in catalysis 30, 1-90 (1981).

[5] Balsama, S., and Forni, L. Appl. catalysis 13(1), 161-70 (1984).

[6] Bennet, J.G. Jr. EP. 129065, 27-Dec 1984.

[7] Lopez, A.F., and Suarez, A.R. Appl catal 15(2) 235-45 (1985).

[8] Mitnik, U.V., and Komorov, A.G. Deposited doc 1984, (Moscow chomical technology institute) Moscow, USSR.

[9] Brazi, E., and Robin, A. Jour. Amer. chem. scc.107(12) 3534-40. (1985).

[10] Luank, S., and Sed1ac, P. React. kinet. catal. lett. 26(1-2) 39-44, (1984).

[11] Essam, Mohammad. Indian patent document 151,656. Jurie 18, 1983.

[12] Fraenkle, Dan. "Eur. pat. appl. 126,245. Nov. 28, 1984.

[13] U.S. patent 5l4, 748. Jul. 18, 1983. 


\section{CHEMMCALPRICES}

\section{WEEK ENDING JUNE 6, 1986}

This chemical prices section contains spot quotations and/or list prices of supplers of chernicals and rolated matertals on a Now York or other thellcated basis. The listings are based on prico information obtained from suppliers. Noto that posted proces do not necossarly represent levels at which transactions actually may have occurred. They do not represent bld and asked prices, nor a range of prices over the week. Price ranges may represent quotations of different supplers as well as differences in quantty, quality and location. All matters under this heading are hithy covered by copyright.

\section{An index of wookty chemical mark of reports be on the beck conw.}

A

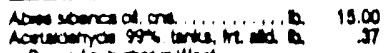

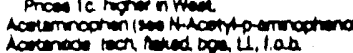

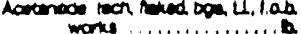

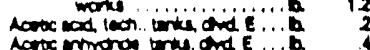

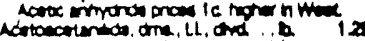

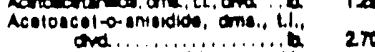

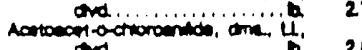
Acoloucetorolovioion, amo., i,

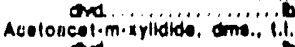

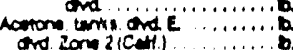

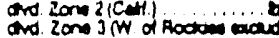
comoming anxiti in ........

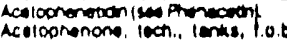

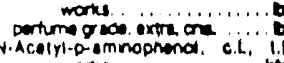

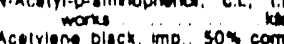
Acolylono black imp. $50 x$ com

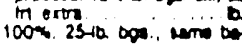

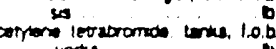

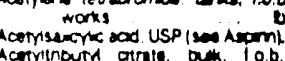

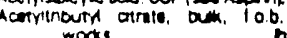

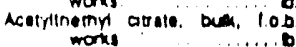

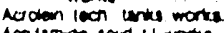

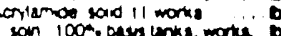
aciylic acid gracial, iog lankg. toch ences. in in

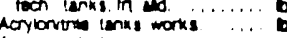

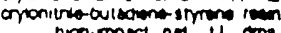
ard mact na........

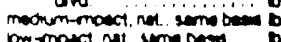

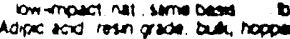

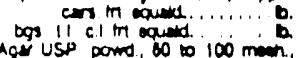

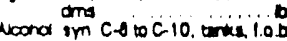
c. 12 toc 13 . imes and C.16 10 C 180 ind and

Cit ama

C.10 कro

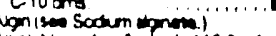

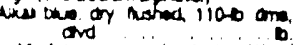

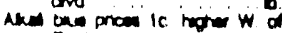
Alsprice Quntionsesen / Honowem. Jarructon og

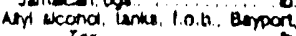

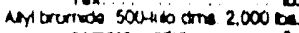
Arrt cor incro rans

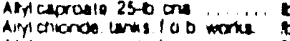

Arrisolnocyanale bors

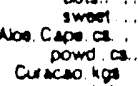

curctoning

Nem mornorum roch orem bog

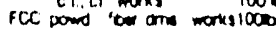

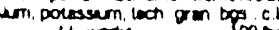

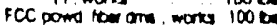

57

0.50

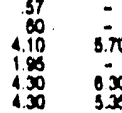

$3.72 \quad 5.00$

$1 \infty$

5.50
3.90
65 65
340

$350 \quad 300$ $\begin{array}{ll}200 \\ 2.25 \\ 2.00 & 2.75\end{array}$ $3 \infty 0$
6.0 3500 3500
3500

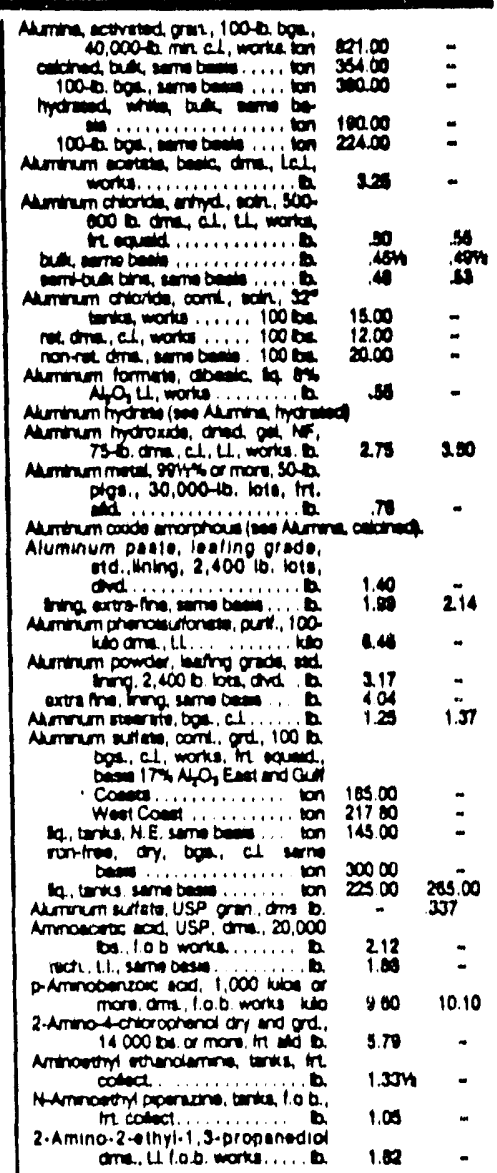
1.00

\section{$\left.\right|_{0} ^{2}$}

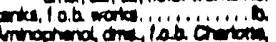

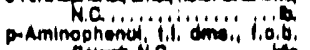

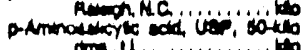
Amornm in

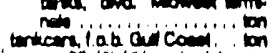

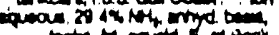

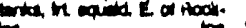

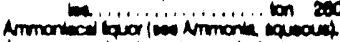

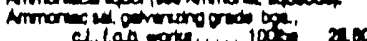

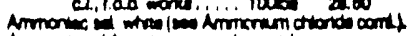

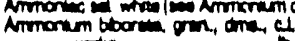

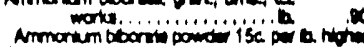

Armorium becrbonet 30060

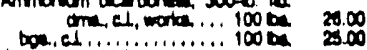

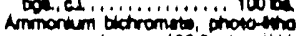
goro orm 100 an itit

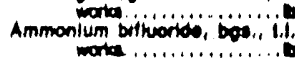

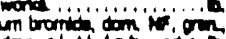
om ci, los ontato in of

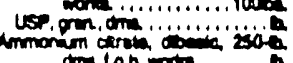
in $\tan$ mot......

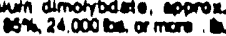

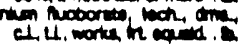

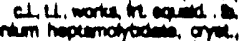
time. 24,000 in ita.

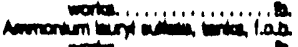

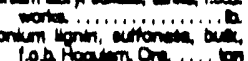
loob forming on on

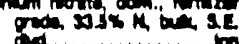

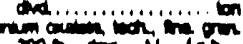

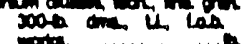

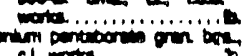

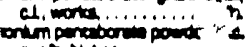

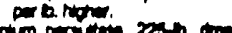
24.000 on ox mond 1.0 .6

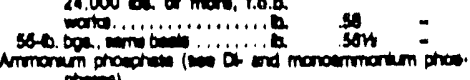

\section{0}

10000156.00 Amonim

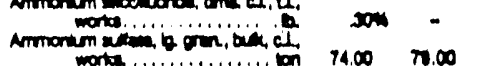

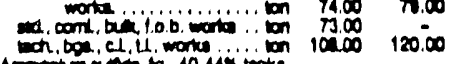

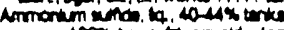

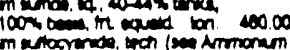

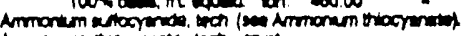

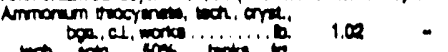

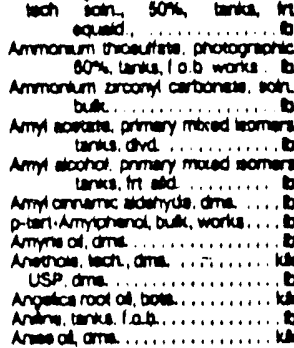

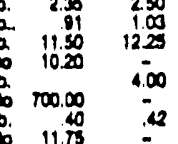
1.421 .0

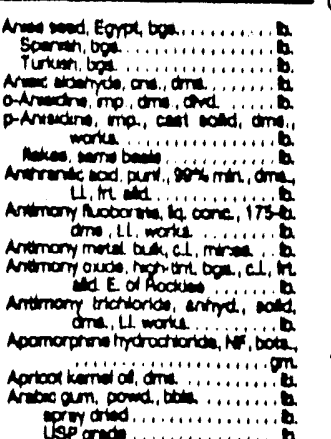

0
100
200
200
1.00
3.00
1.00
100
1000
200
200
200

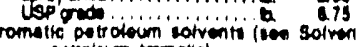

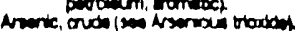

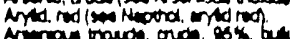

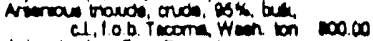

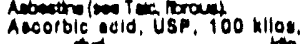
Aw and ................

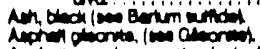

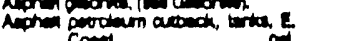

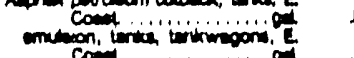

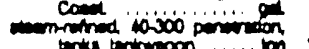

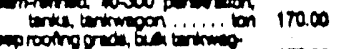

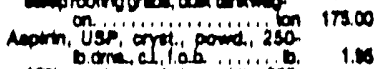

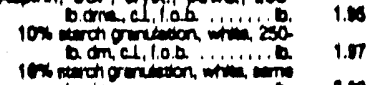

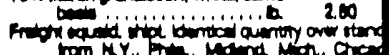

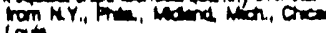

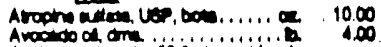

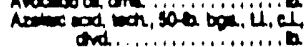

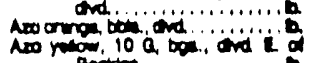

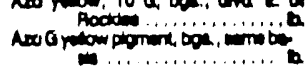

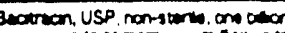

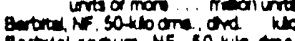
m, NF, santwo ons and sonting 200

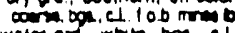

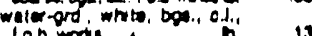

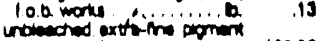
enim cow c.l.

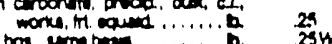

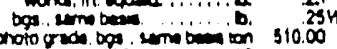

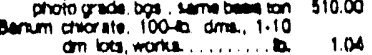

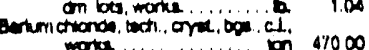
ind on 47000

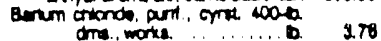

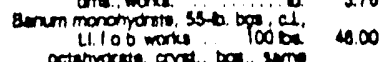

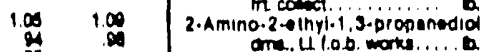

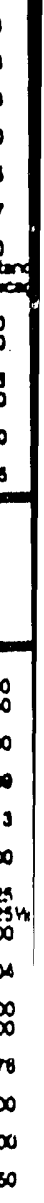

\section{ABBREVIATIONS}

\section{THE TERMINOLOGY OF THE CHEMICAL MARKETPLACE}

and
and

ermons

and

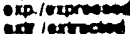

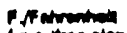

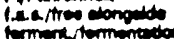

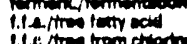

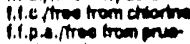

n.

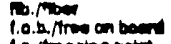

10.

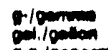

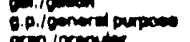

orroniorement

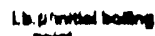

impimporm

等

lorm

ardortions

proposportion

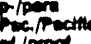

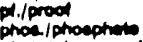

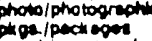

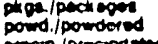

prodiprosicen

pelporst

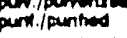

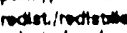

nta./rolmed

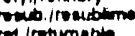

solepeciaty demenes

SO/spociaty donanom

secsourteander

\section{ara

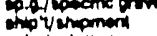 and onimineste

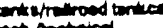 (n) il/ fruction of 2,000 pounde tory elowence

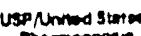 ina irrocony

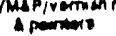 \\ m/Wom

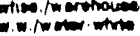


" orow grd. and cat

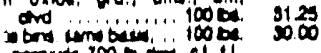
- portion.

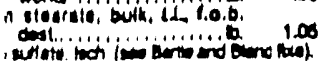

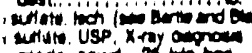

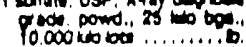

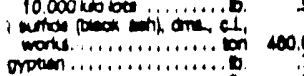

i. comini...'......

$\operatorname{sen}$

cond ver ............

- colland otractory ordo

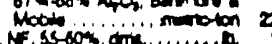

Tymur bos biaicha........

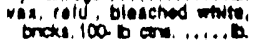

mo slobs 1000 con.....

tor $100-1000$

mond in a............ ton

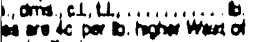

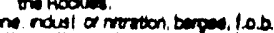

Boron Alags Le

Boptom. Tex.

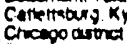

Crecopo dermet . T.........

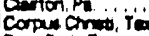

Dow Pun, Tox

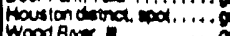

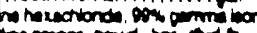

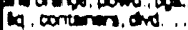

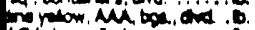

COT Oog and

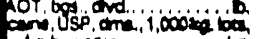

co.b. mons a.........

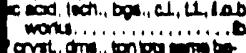

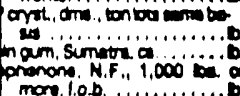

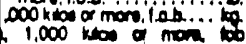

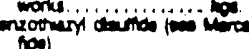

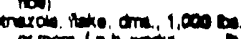

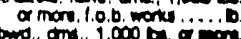

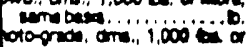

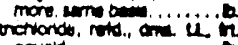

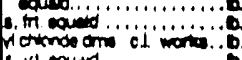

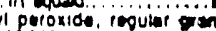

10.000to ba a man by

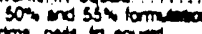

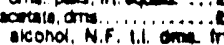

candi.

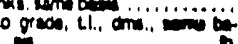

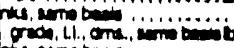

onverta an ............. ib

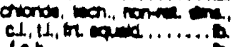

comentitio 250 . o.......

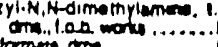

tormese ame

prooment om

arrome.................

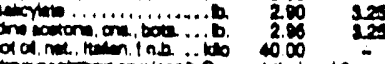

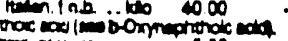

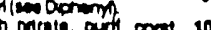

o. ons in ary or.

oxper ..............

pow 256 and

om wore. Pu.........

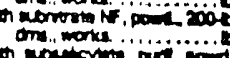

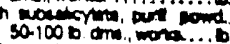

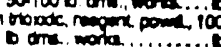

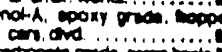

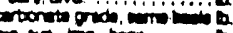

boim in mo

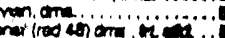

32)

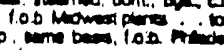

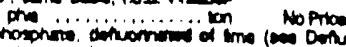

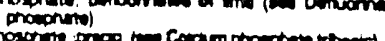

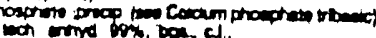

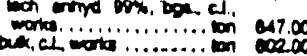

is

3.20

2.00

1.06

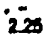

iss

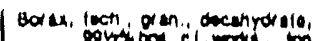

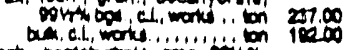

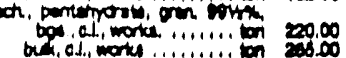

bonax, Af isen sodumboriti.

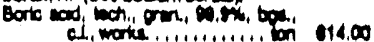

wa.

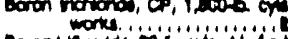

200

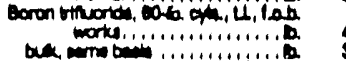

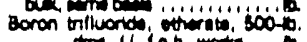

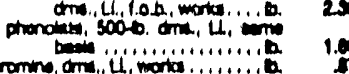

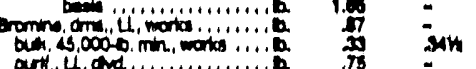

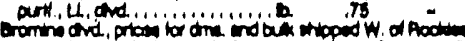

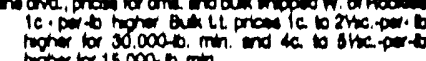
mor 15,000 - b. mint

Eromod mand i...............

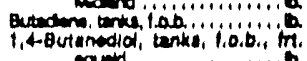
काming

noum coment on tor in

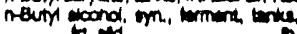

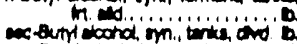

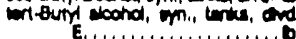

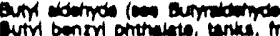

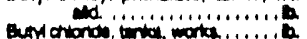

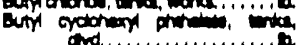

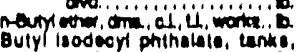

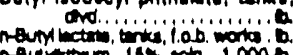

nourtmon, $18 \%$ oth 1,0000

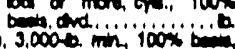

$\prod_{20}^{1.12}=$

:

in

$\$$

.0

舟

101

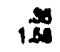

16.46

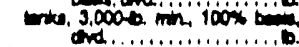

14.78

butyl mothacrylolo, lanks,

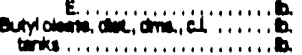

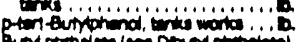

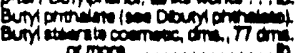

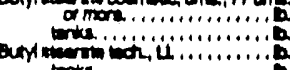

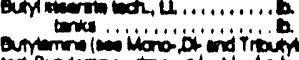

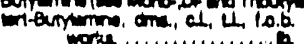

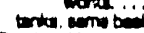

cunfind moram

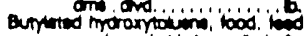

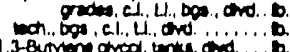

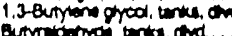

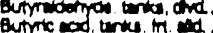

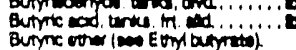

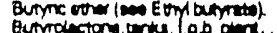

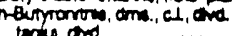

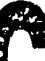

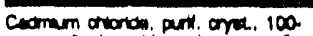

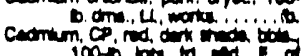

$$
\text { Anotion.............. }
$$

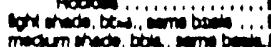

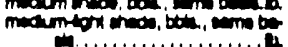

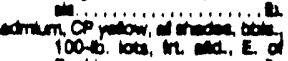

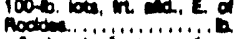

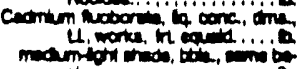

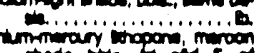

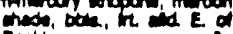

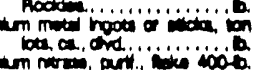

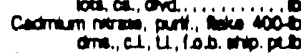

monchich

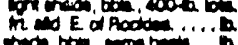

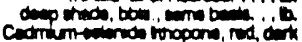

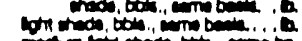

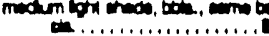

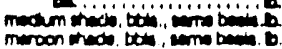

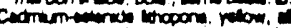

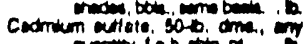

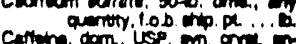
ind pond,

mo. or mond pond

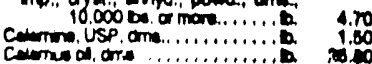

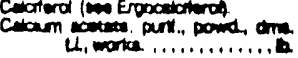

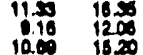

10201400

0.107 .07

$2 \pi$

22

100

120

100

$297: 300$

in

a.7.

20200

400

400

$\int_{1.00}^{4.1 .0}$

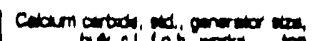

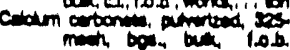
mond

ben

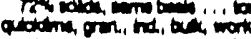

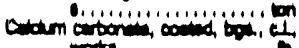

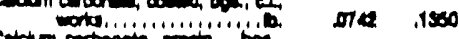

Catem d.

140,00

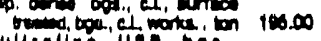
ulirallino, USp, bg:.

1000 17000 ox, llake, bulk, el

100 a

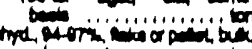

217.00

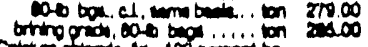

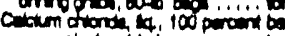

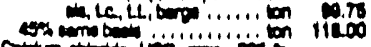

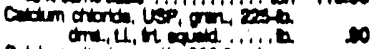

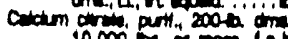

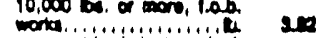

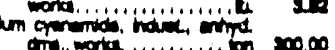

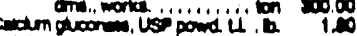

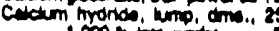

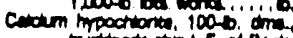
100.1 .1 .1 .100

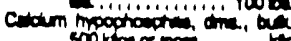

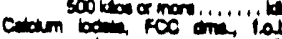

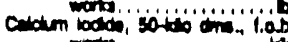

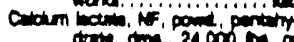
moni 1 ab motes

rom

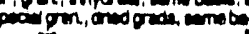

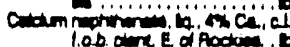

lob ane a A Adom, 100

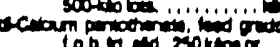

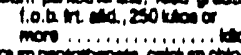

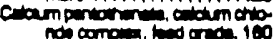
Comos $2.100 . M$

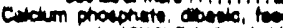

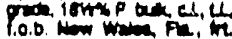

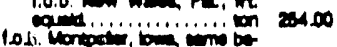

(1) 2000

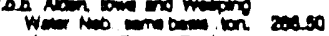

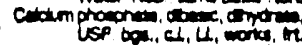

mation.

Complico monomprasti, tood proto

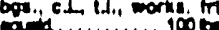

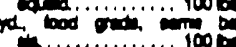

con am prosons dis 2000

0.50
71.75
0.80

0.50

and

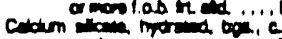

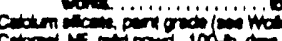

$\infty$

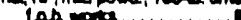

conprof........

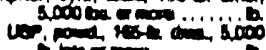

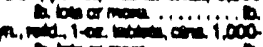

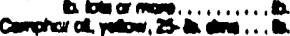

mon

connex of inom on

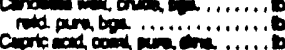

a d....................

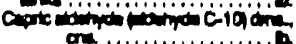

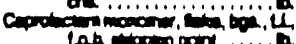

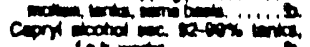

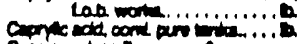

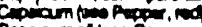

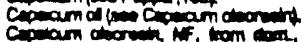

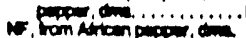

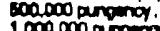

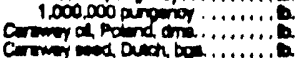

copom boe .................

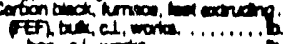

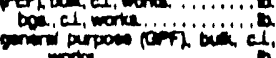

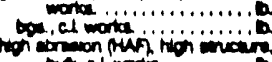

ber, cil monta.

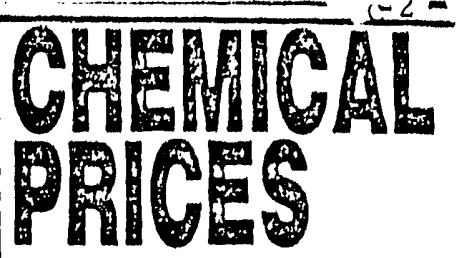

WEEK ENDING JUNE 6, 1986

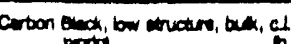

bon cel monici.

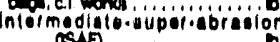

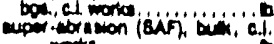

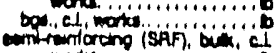

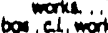

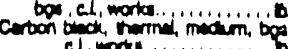

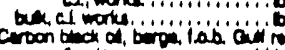

1.0.6 W.

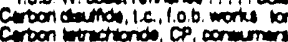

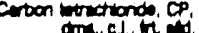

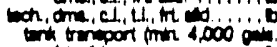

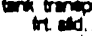

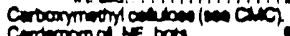

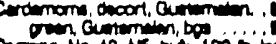




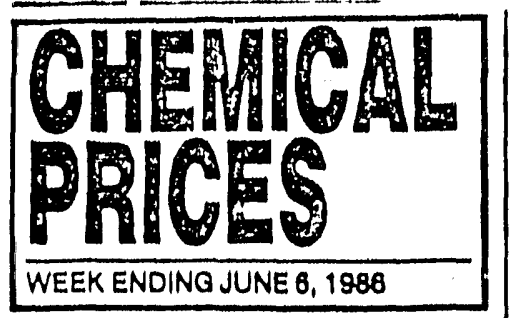

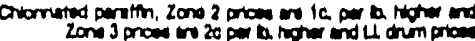

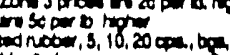

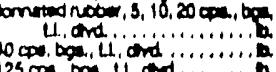

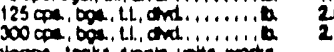

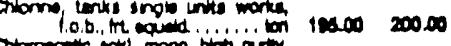

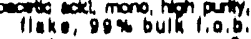

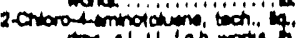

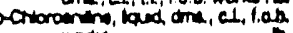

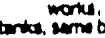

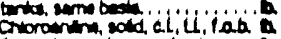

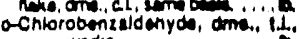
mons a a mor morta.....

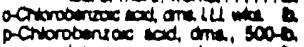

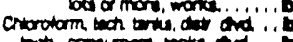

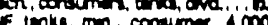
pet and............. modity besio, dma.. li...

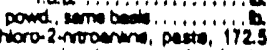
mal mi composty on

o.chlorophenod, dma., d.i.i., in p.cnlorophenoi, ama., e.i., in.

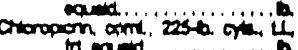
chlorosullonis esto, ienini, in.

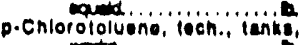

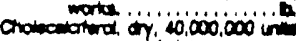

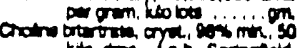

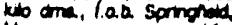
Ha.....

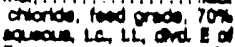
Aodvon................

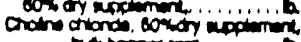
$10.000 \mathrm{ran}$

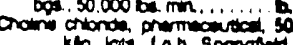

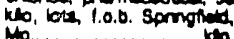

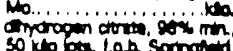

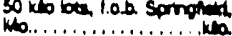

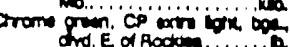

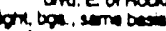

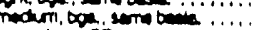

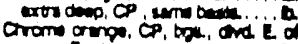

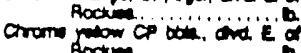

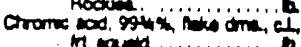
mom

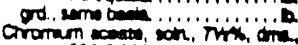

chromium fluorida, ams., t.1.

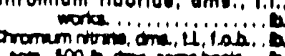

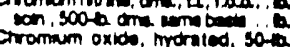
and bon al al.

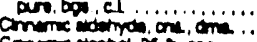

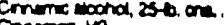

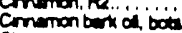

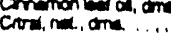

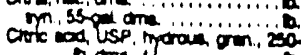

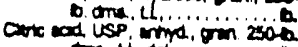

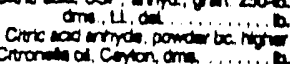

tom on anton..............

crooneled

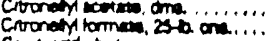

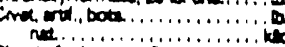

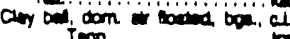

com. crivion nocarorion

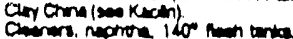

$$
\text { Now serioy of Now York. }
$$

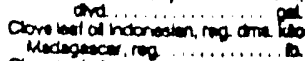
crow out al

Zmutor.

$1 \infty 2$

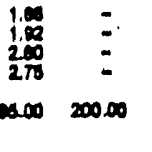

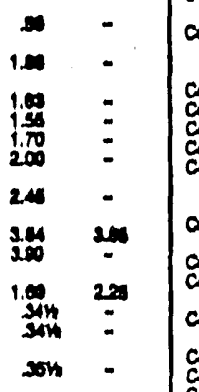

${ }_{210}^{300}$

$\frac{2250}{2 \pi 0}$

2.0

1251.70

$\tan$

100

2000

$\infty$

24n 2

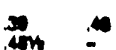

200

$\infty$

1,00

i. 7

$\infty$

1.001

1.10

.10

1.10

200
240
1.10

1.10
100

in

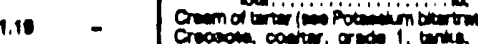

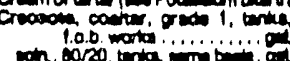

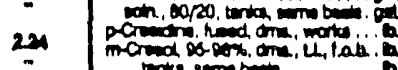

70

00

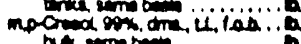

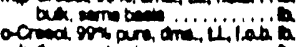

arem

$\rightarrow$ and on

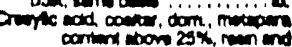

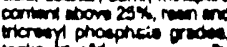

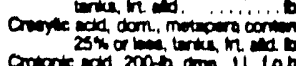

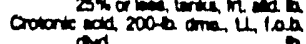

200

$2 \times 0$

200

andotion

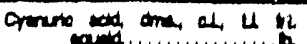

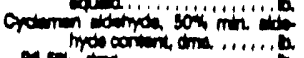
0,5 ind ordonem and .............

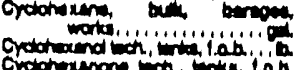

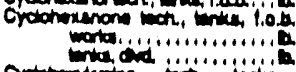

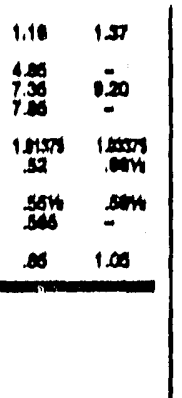
3000

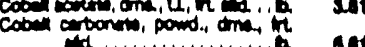
i2.

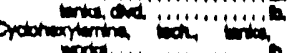

然

24

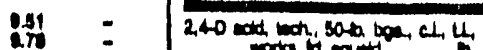

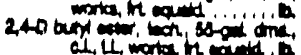

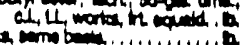

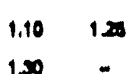
2.40

ind

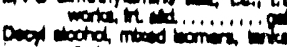

1.20

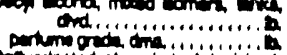

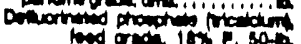

5 a tab ton

2000

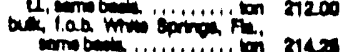

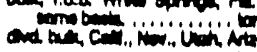

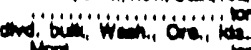

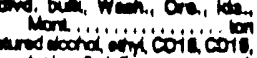

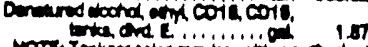

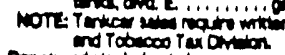

$$
\text { and }
$$

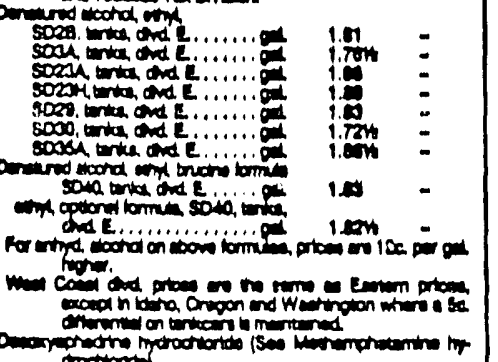

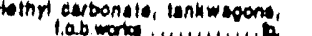

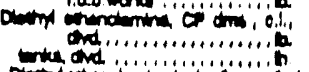

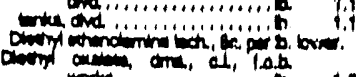

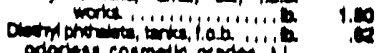

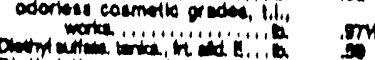

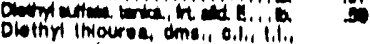

a-2 -

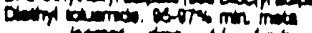
comer. ons. I. 1.0.6.

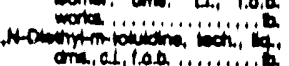

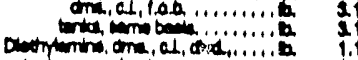

tran

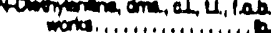

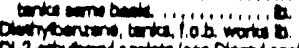

\section{Daver}

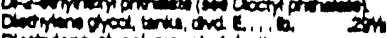

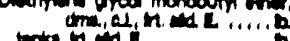

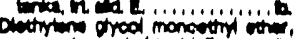

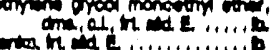

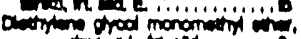

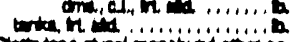

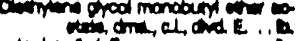

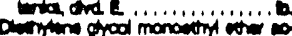

and at the

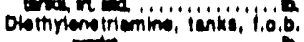

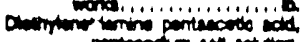

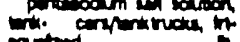

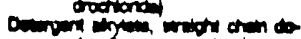

Tob ................

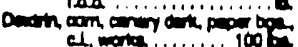

mile pepor opo 100.10

nou

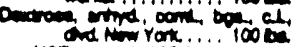

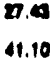

ond 100 on

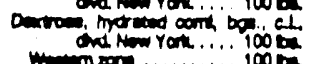

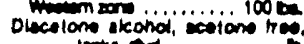

and ond and........

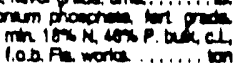

1.00 . w ond

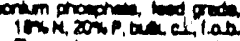

Pow

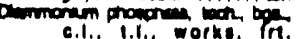

ond in

420

200

1280

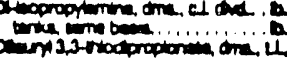

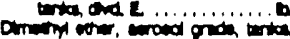

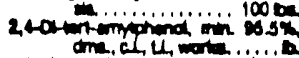

$52 \pi$

tar on on

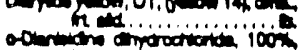

$\infty$

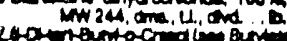

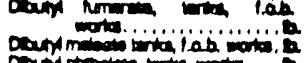

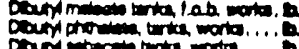

dom on and a.....

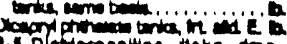

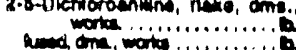

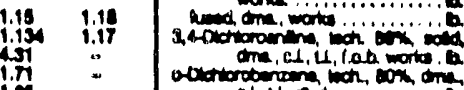

ation

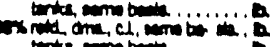

crion

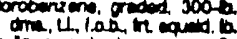

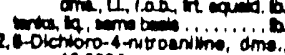

10,000 be a more noma

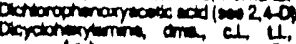

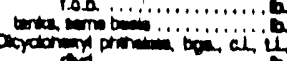

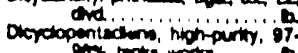

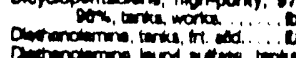

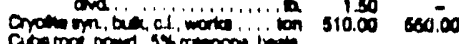

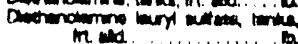

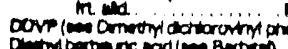

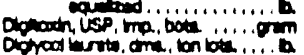

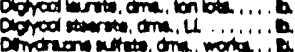

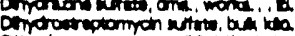

oinydroxyecelone, 30.kito lots.

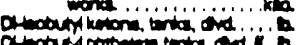

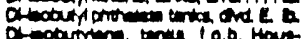

a on w...................

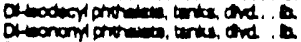

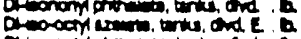

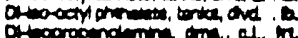

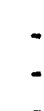

$1400 \quad 150.00$

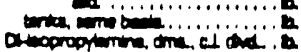

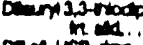

onmenom and and........

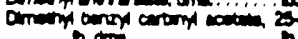

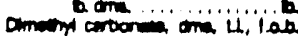

Drench

and on ane ond on

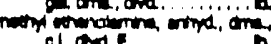
artang

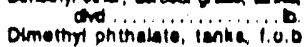
ormenry sodecate, ienta, 1.0 .6

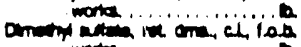

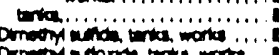

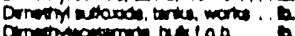

1.04

4.25
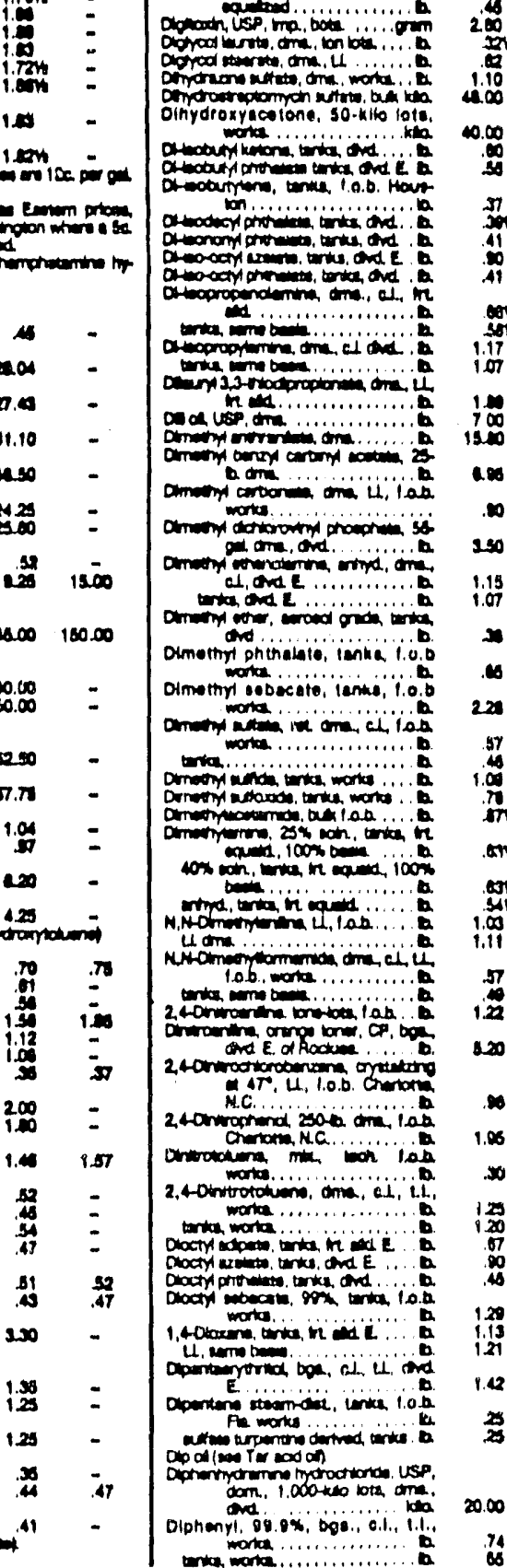


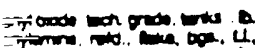
man $m$ m mones Torndo.......

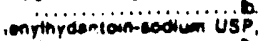

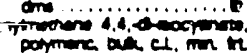

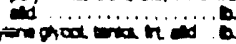

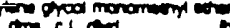

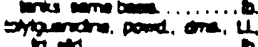

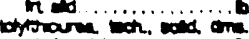
H.m a...........

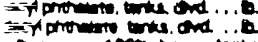
gomeme, 1000 ben.

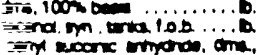

c1 11 od ..........

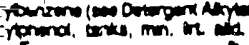

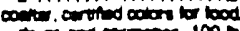

ongs ind ocomect 1000

Foid no i.

No 2 . ......

accicis 3

........................ an conmetce 1000 bo

ated in 5 .

pucing

oicino

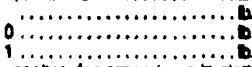

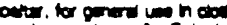
in Nemes lab wons

$=1$ Bur bex ta conc......

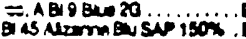

B 90 Nom Bro 0

or $16 \mathrm{~cm} 20 \mathrm{xy}$

Yo 10 woo or

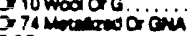

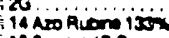

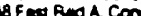

151 Sed $38 \operatorname{con} x$

17 SAN? Com

Hows con

ir far lon Yaza.

3 I Zne Frew ............

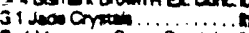

3 a Mancrearion on

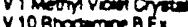

$Y 2$ Band $Y$ in SF $A$ 150\%

Ex $\operatorname{con} \sin 6800$

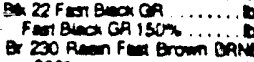

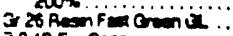

248 ex con 1 .

Gi Po Redral.

OSI f Som $A v$

Tice ferorop wsoin.

$Y 4$ Bnilient Pape Yoil $30 x$

125\% ... revaxing....

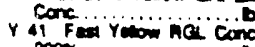

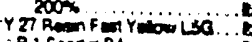

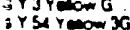

- O jorroe GR

iv 3 : 0 on 00

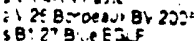

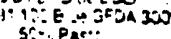

G)

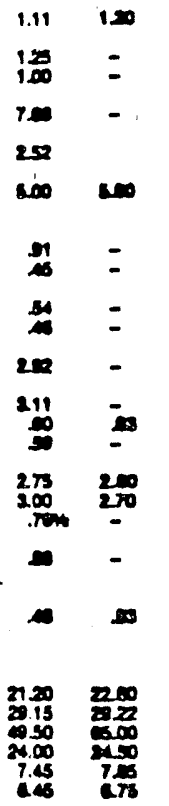

300
18.00
3.50
12.4
50.5
21.0
20.5
40

is
| senging

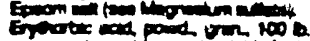

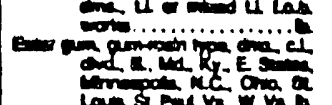
constark whe

\section{an} ox a...............

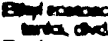
ard and ino.....

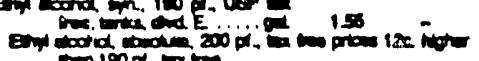

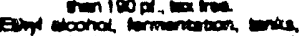

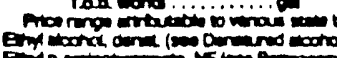

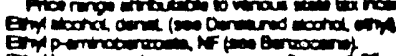

Exil

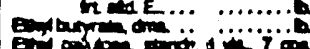

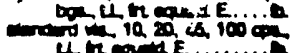

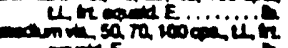

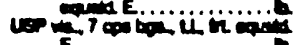

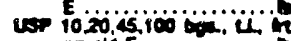

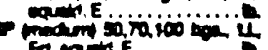

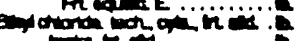

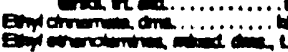
and

En

2er

2tarmery E..................

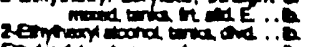

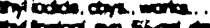

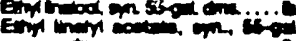

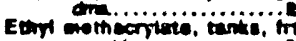

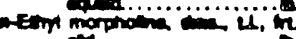

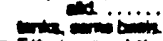

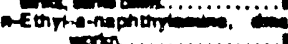

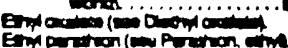

Ex d on rom

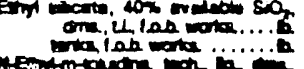

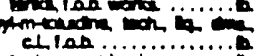

tha mo

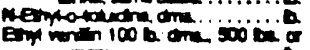

20 an soik o...........

1000 on 500 o.

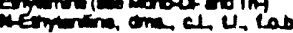

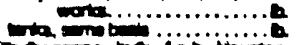

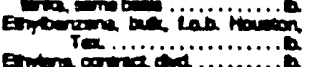

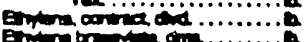

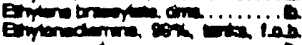

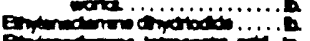

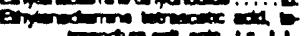

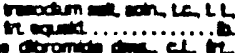

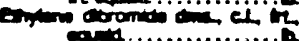

in

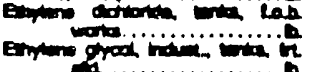

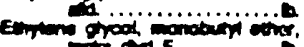

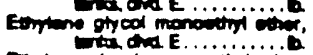

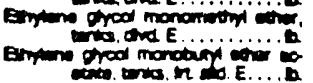

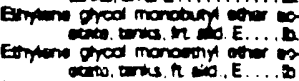

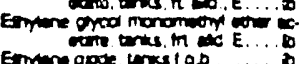

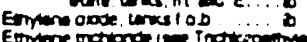

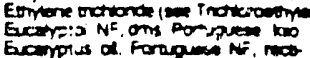

hod 70,75 , ors

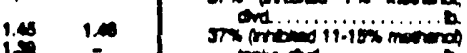

Tramed

Formumat ina 10 i

$\frac{218}{210}$

$=$

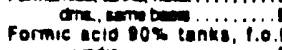

sxame.

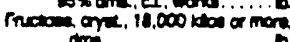

140

is

is

130

$\lim _{\lim }^{\infty}$

1.00

$\sin$

$\rightarrow 2$

17.17

$x$

An

s4

enc

sors

is is

inas $=50$

1

$1.10 \quad 1.15$

1.11

and

ancl corta ............. 141.00

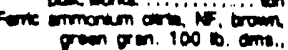

$x=000$

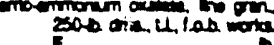

modom

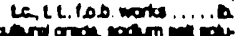
on for Fa LE I L i las

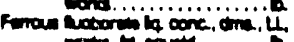

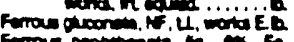

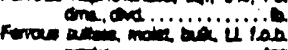

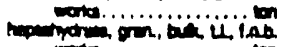

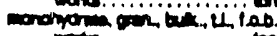

us.

Ada conocos

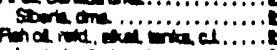

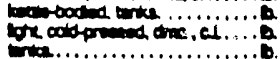

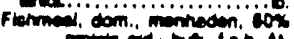

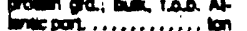

rab ar por ...............

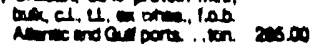

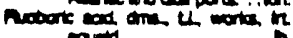

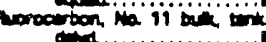

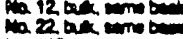

Nolls

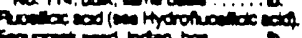

forment $37 x$ mom

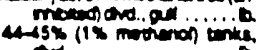

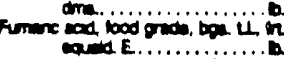

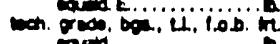

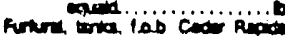

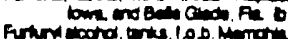

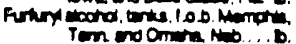

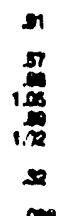

1.14

.1018 .1000

0.00000

.1000 .1000

4

$\sin$

$\infty \quad 1.00$

son

.3

8

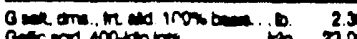

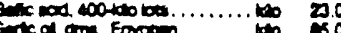

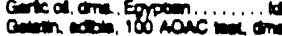

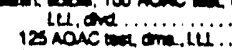

150 AOAC on tII

175 Aac om lic

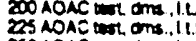

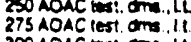

300 AORC tes: ons IIII

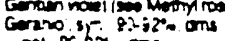

na: $\log _{x \rightarrow 00}$ and

cormam ar morocom

Eort. ................

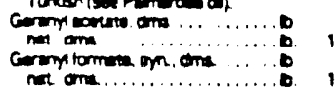

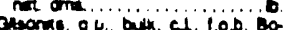

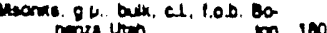

consts

$\operatorname{comoucosim} x$

compon Amad and

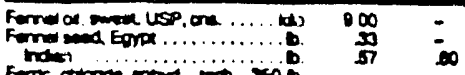

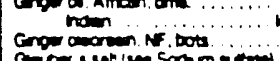

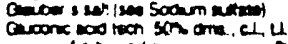

10.0 tom
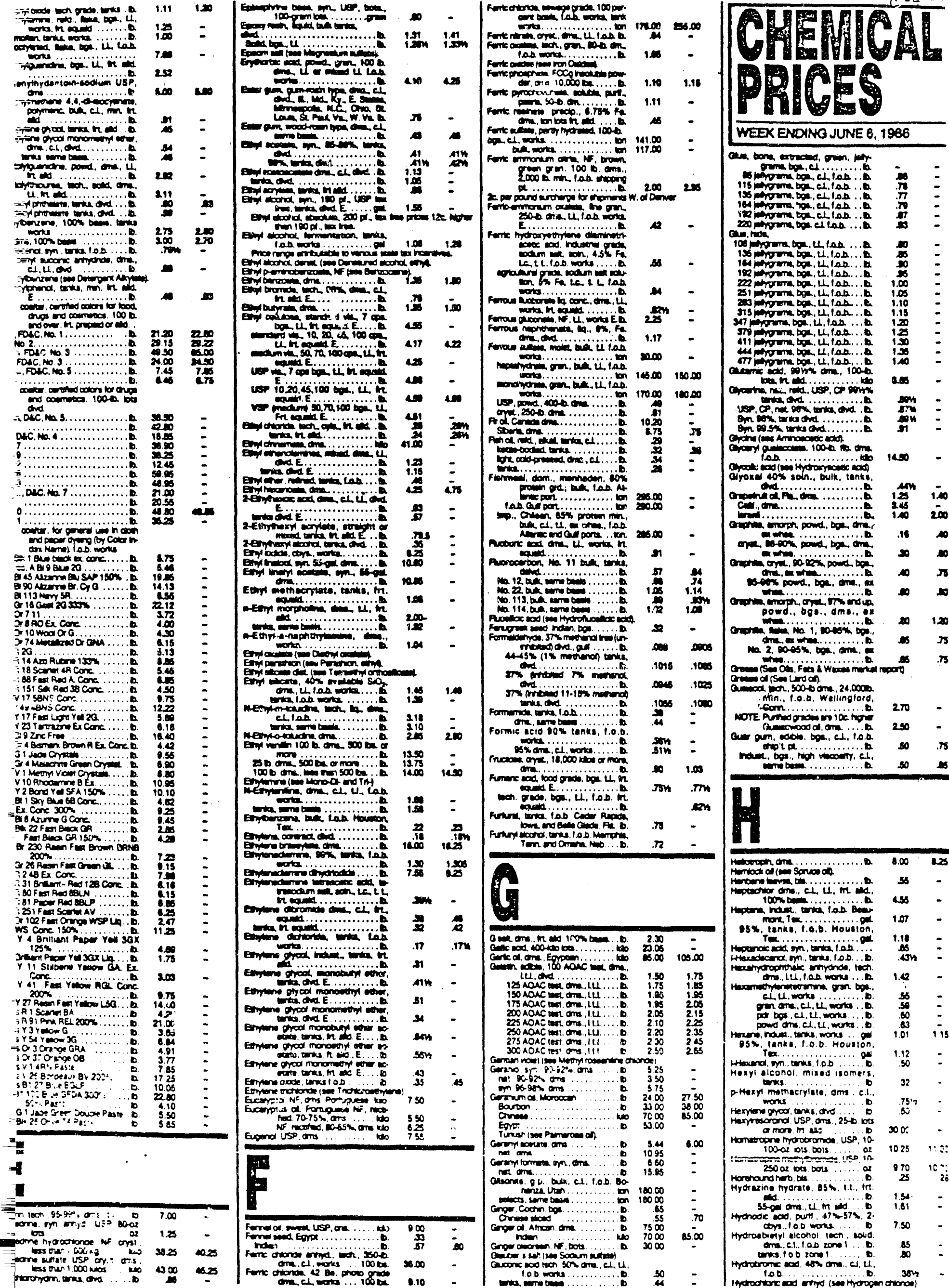

WEEK ENDINO JUNE 6, 1966

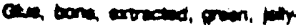

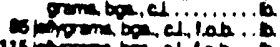

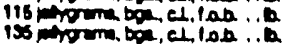

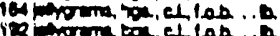

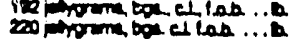

(2)

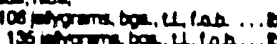

is rorma

180 moma $4.100 \ldots$.

$x_{31}$

200 prem L L L L

IT)

SToporm bo, i.106...

4if

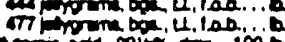

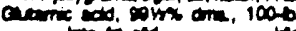

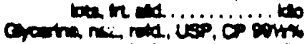

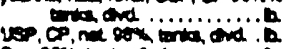

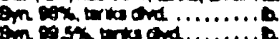

Im mix wrowand

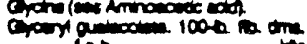

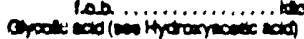

arpexe $40 x$ soln., bulk, lento

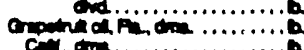

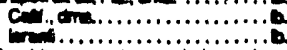

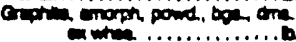

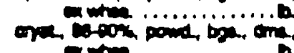

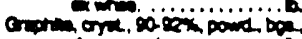

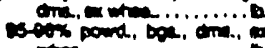

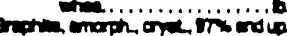

poord., bgo., eme.t ox

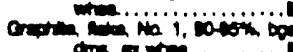

Mo 2 .

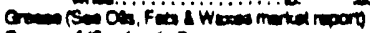

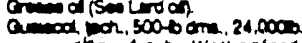

inta. 1.0.0. Wallingtord.

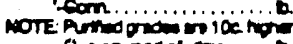

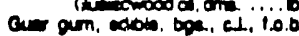

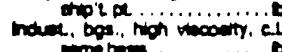

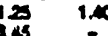

$1 \infty 200$

$.16 \quad 0$

$\infty$

$\infty \pi$

$\infty$

$\infty 120$

$\infty \pi$ 


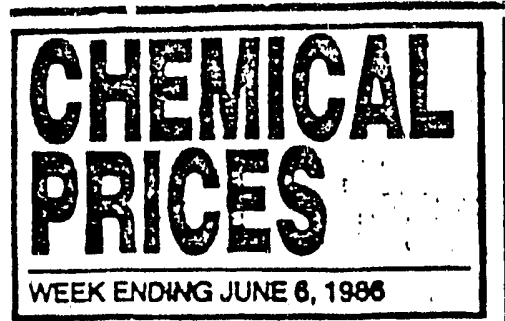

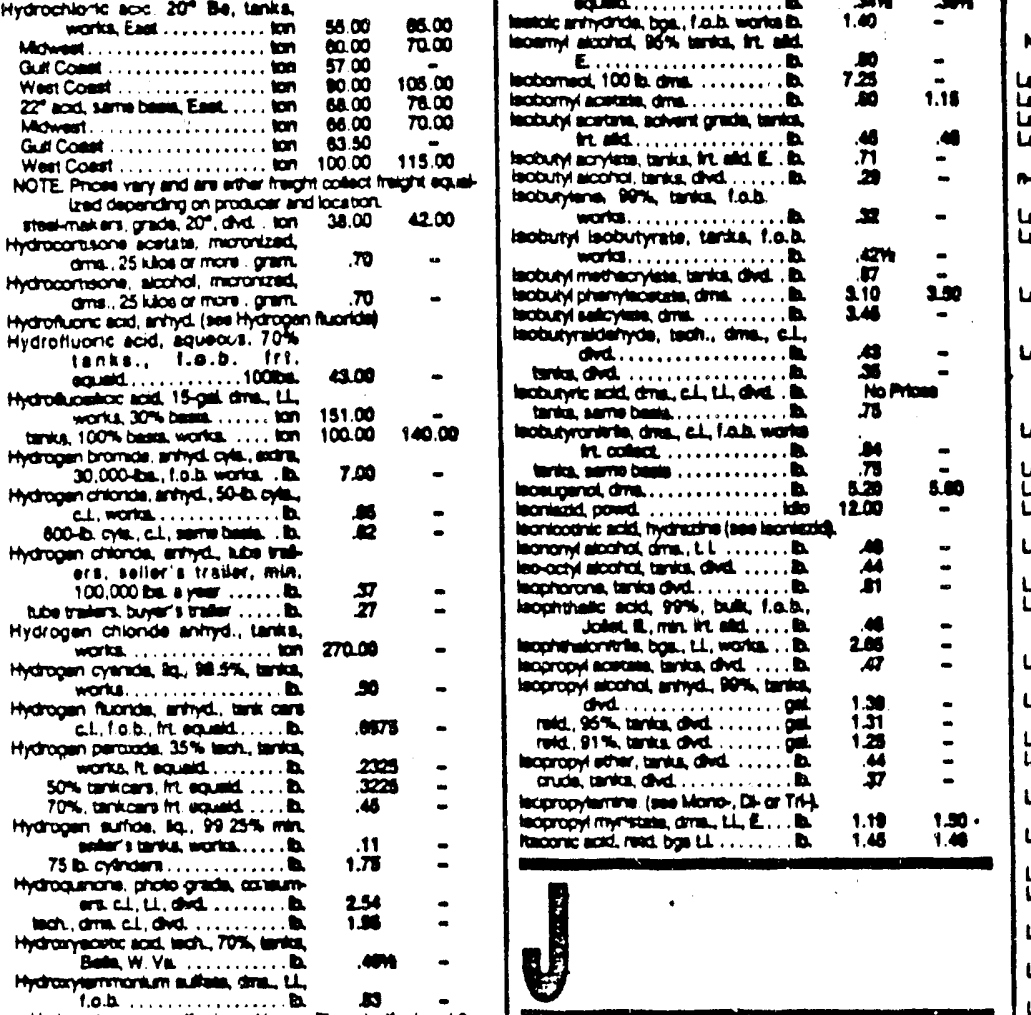

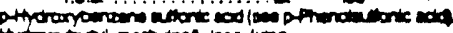

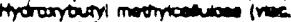
$12.000 \cos 150$ b o 14.4

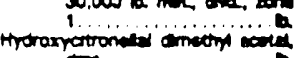

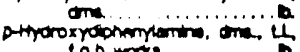
100 mon.

nos at ane.

are on

not gion an ............ a

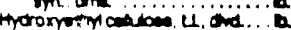
5.000 trang 45.00000 .150

- I. C. 301000

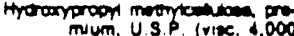

mum, U.S.P (visc. 1.000

u. c1, 30,000 o $\mathrm{mon}$ and

rom 1 ............ is

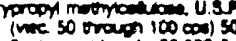

b. U. $11.30,000$ :

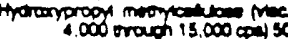

b. bea U. CL $20,000 \mathrm{~b}$ ?

ord rone i ……

50 throun 100 cost so -

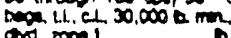

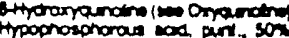

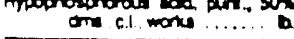

210

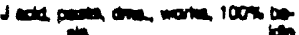

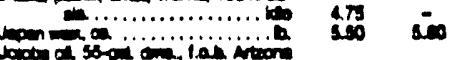

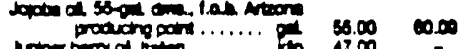

1268
410

1.40

13.00

$207 \quad 212$

$2 \pi$

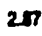

200

217

264

215

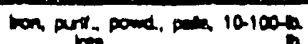

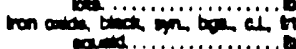

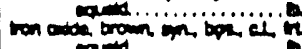

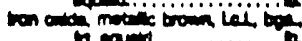

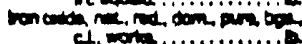
ming a in in.........

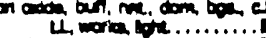
n....................... olhor thedes, boe., c.l., in on

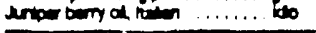

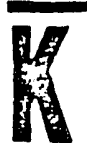

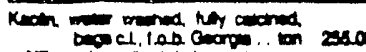

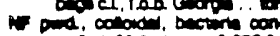

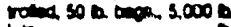

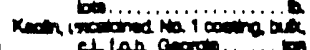

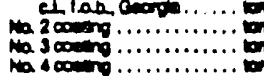

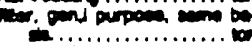

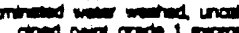

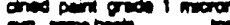

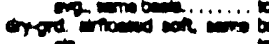

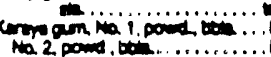

tar 2 pom

3

Lecour aturn perodeam, 1 cor

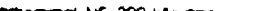

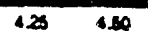

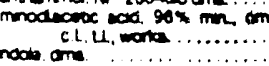

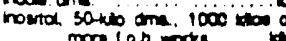

more lob corke......

tro an 100400 in in

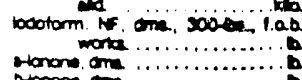

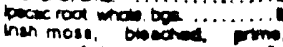

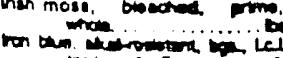

lonbea on E......... Le

nog.

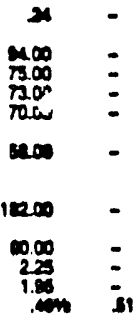

$\lim _{200}$

is

120120

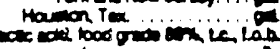

mane .................

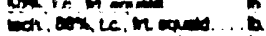

200000

$\prod_{10.00}^{200}$

1310

\&.

Lan ............

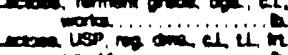

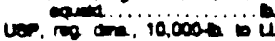

r.o

1.0

22

urmat

340 los on and un

in

Nom

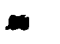

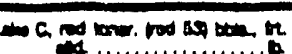

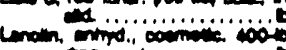

$\pi$

-
100
100
$=$
-
-

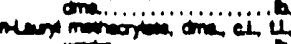

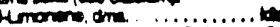
Irmed of mon.......... phemeonten ioj......

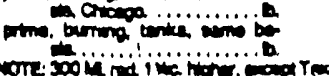

con

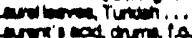

anc cotat ocm por bog. a.....

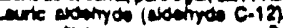

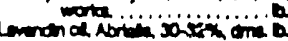

ond hom ond ........... b

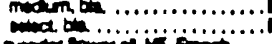

40 47x or on ............

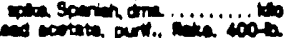

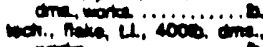

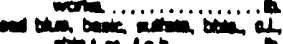

tat p.tab.........

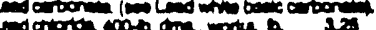

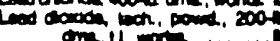

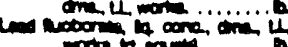

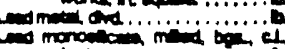

t.0e wortal ........... \&

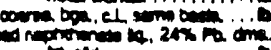

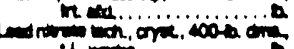

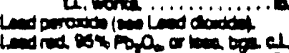

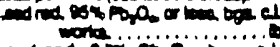

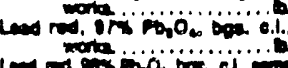

(1)

Lew alleochromato, bog., c.l.

Len

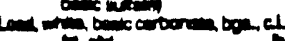

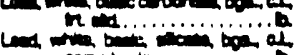

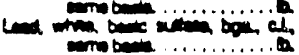

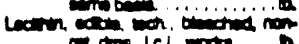

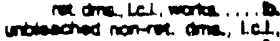

tim on

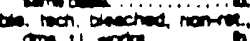

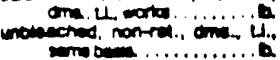

(a)

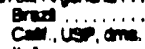

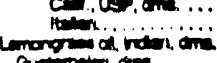

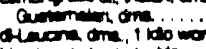

ore.

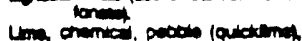

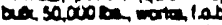

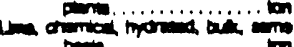

par. 100- din.

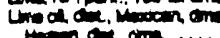

arian om

apration

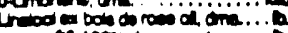

m. 90-1007 ans wonda.

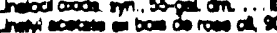

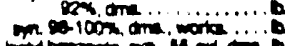

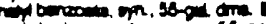

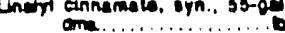

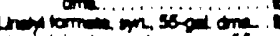

Lner lecourrats. im., ss-get

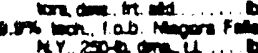

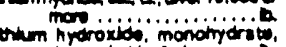
one, at, 1 , and.......

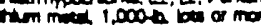
ad............. io ios

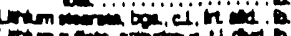

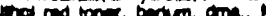
and a...............

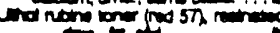
loom om am pond ope.... tropodem soto on

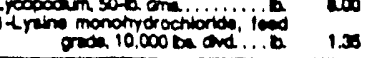

$\begin{array}{cc}i_{0}^{\infty} & -\pi \\ 1 . \pi & - \\ 1.0 & -\end{array}$

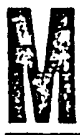

$1.10 \quad .10$

1200

simeng

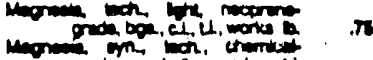
ond on

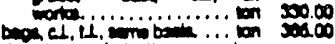
cocowimed, butw, semin bo

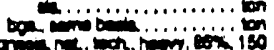
$\min 100$

H.............. $20 x$

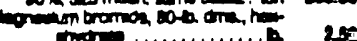

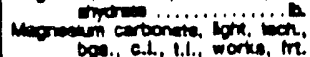
o. us nom on

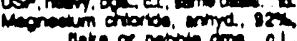
nate of pobow ana. of.

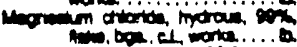
monem

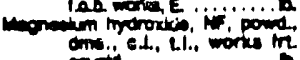

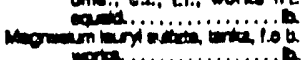

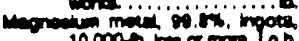
mimen ir.......... con on

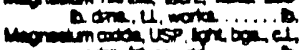

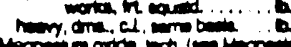

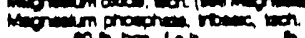
- 00 og 10h ........

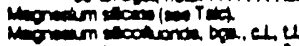

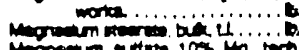
max.

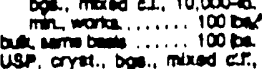

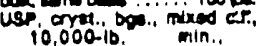
10.000-16. ming mon 1.7. 30.000 10. min. bult. 0.1 .100 .000 is 1000

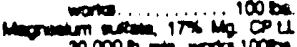
an. c.l. 100,000 to. min. manc

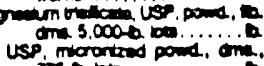

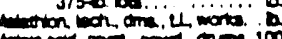

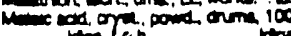
100.

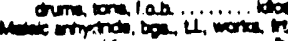

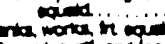

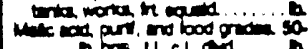

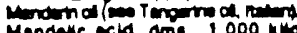

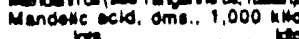

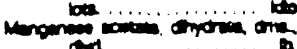

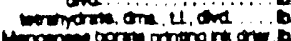

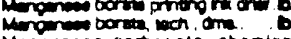
Mengenoue cervonatio. chemente

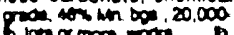

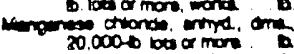

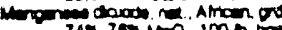

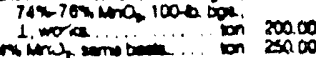

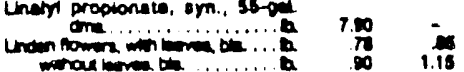

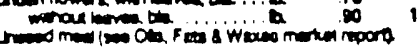

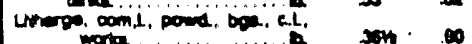

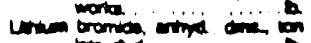

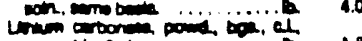

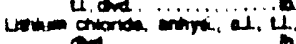

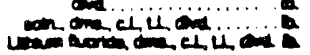

298 


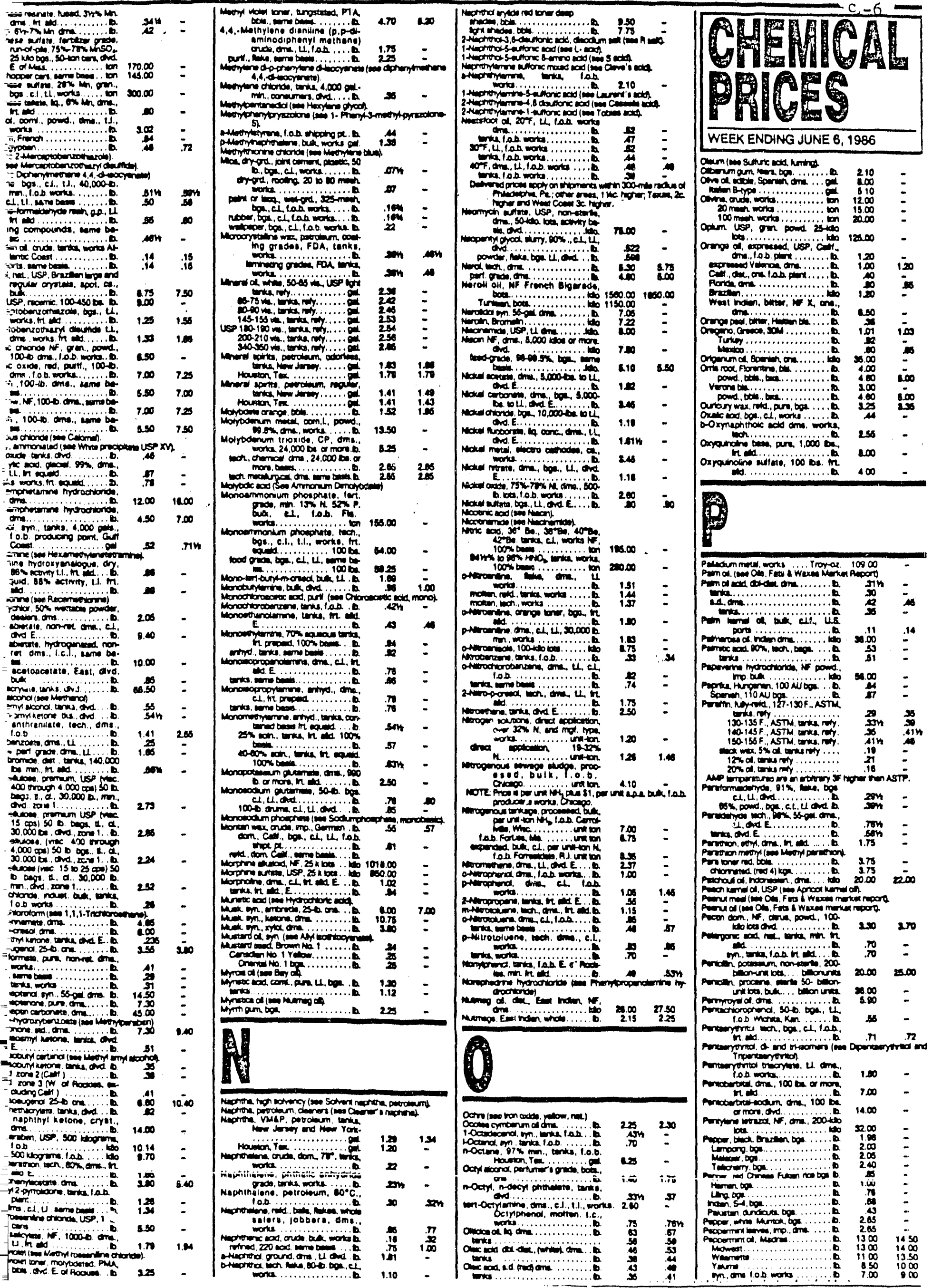




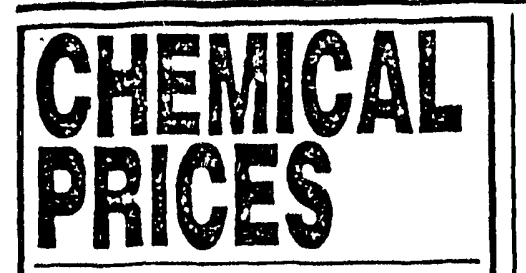

WEEK ENDING JUNE 6, 1986

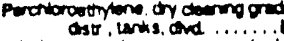

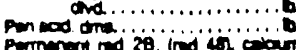

sum ond in in.

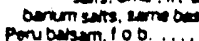

Pomgran a Perainy..............

c.l, noty.

USP, son wivio...............

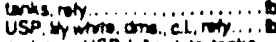

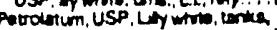

usp oty dine..................

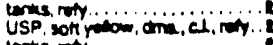

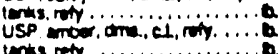

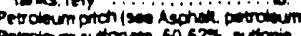

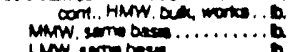

mos ..........

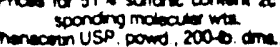

1,0006 or and ......

1000 ame 10000 bos and o

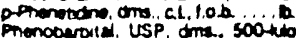

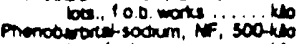

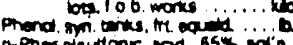

and : C. t, too worte ......

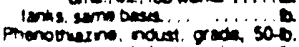

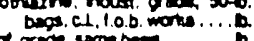

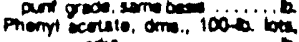

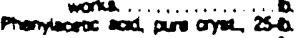

ol.Phonylatanine, oms... 25 hilo

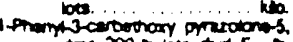

mphemponedem can ane, al

li. $10 b$ worke

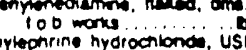

ioonio bots o man

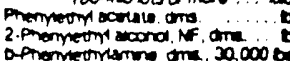

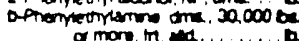

Phenyleinyiphenyl acoicte. 2s-b.

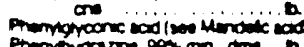

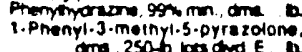

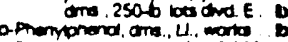

Depremproma, ags, $U, 40.000$ be

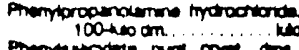

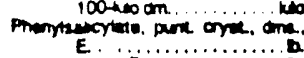

tan, grix. E

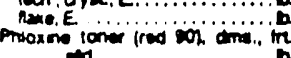

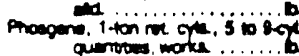

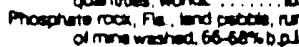

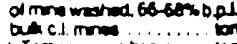

phosphonc ead, com l and ioch oredes. $75 \times$ ianks. onter.

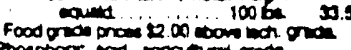

$52.54 \%$. p ar pros.

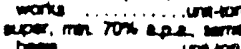

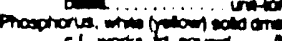

chers

Phosphions oxyctivenct ton

Phos prorus pentesurtion powe

dim cl.

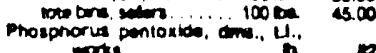

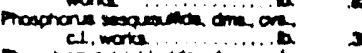

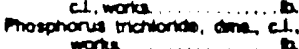

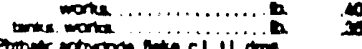

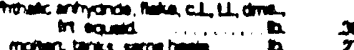

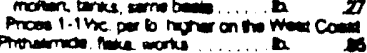

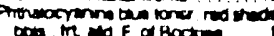

gom in

6.00

$2 . \infty$

2.08

.305

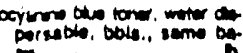

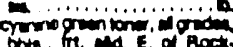
no.................... tam

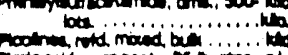

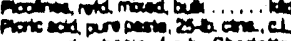

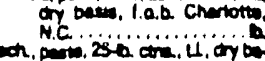

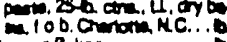
$\quad 5.00$

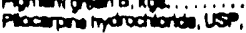

otm .........

1.500.00 2000.00

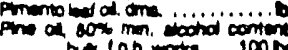

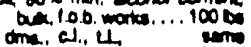

............ 1006

$47 . \infty 5200$

$11.00 \quad 5400$

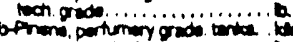

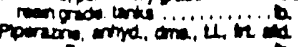

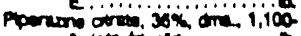

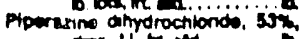

ort. Ll, in wh ....... 1,1006 bes in the

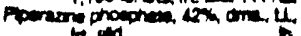

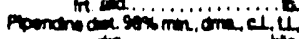

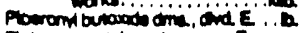

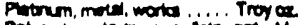

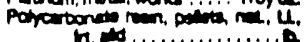

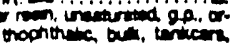

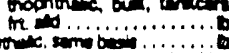

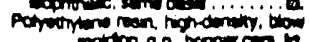

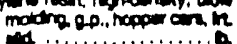
inction inoiding. g.p.inopose

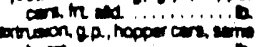

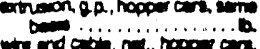

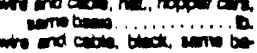

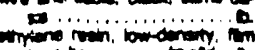

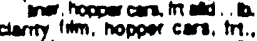

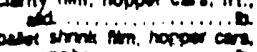
and

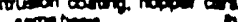

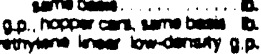
mon

cas fim nom

mon mond low hon molding. O.P., hoppe

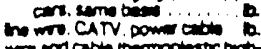

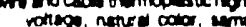
mon

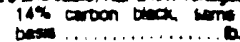

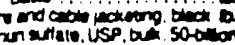

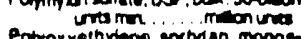

Payouroehrione corbran monos-

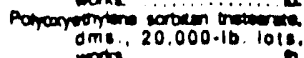
mona................

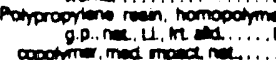

imm $\operatorname{mox}$ na......

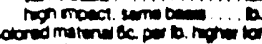

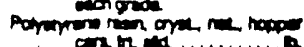

car he a.........

on ringino............

expandatio boes (EPSi) on

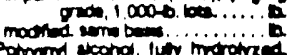

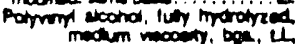
medum nocon, boe. u and ...........

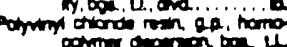
opd................

op repanion, bie. ine

porow be smo bis Potmint chionas. of copotime

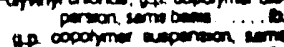

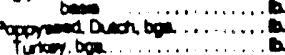

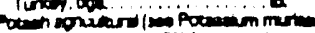

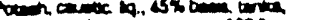
mate cons son bien 100 bo

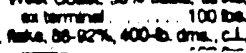

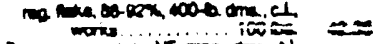

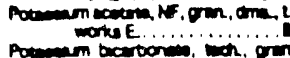

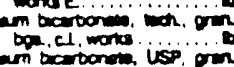

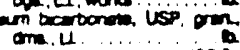

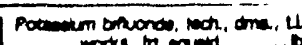
rotes in mat....... bot.................

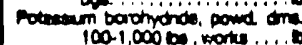

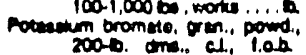
Povmentomin.

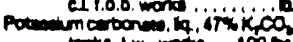

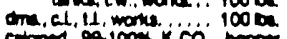
cor of $100 \%$ if nopke monts $\ldots . . . .1000$

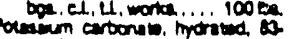
$\cos _{1} \mathrm{~K}_{1} \mathrm{CO}$, om. cl. il.

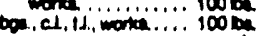
notaimin cortions gro. purt.

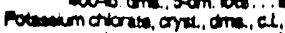

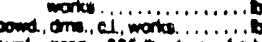

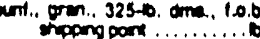

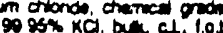
monta.

usp arth one.

USP gron dond

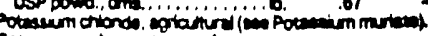

Preasum ctromato. purt., crill.

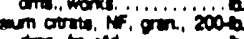

onting in

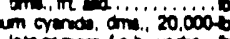
bes or more 1.0.6. arta. it

Poteciom dotron

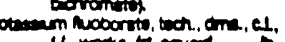

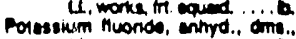

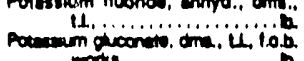

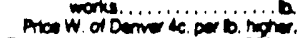

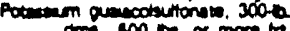
arra. $600 \mathrm{cos}$. of more to

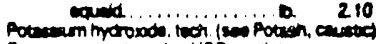

Potenemm moroxion, USP parts. 1006 . om in. C. L. worke. in mave usp o....... b. on 10000 bos and . . b

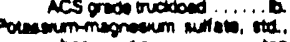

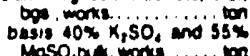

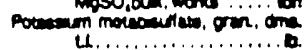

125

10.72

1.31

12.39

59.00

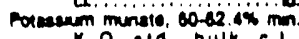

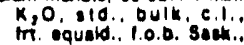

crom

ing

sem lo.b sin.

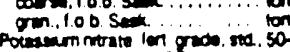

$45 \quad 4$ prived to ad................... in so ton

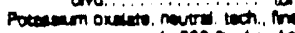

$\operatorname{lrm}_{57}^{72 m}$

orm pond, 3000. din. in

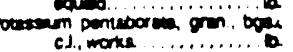

arre sem ba

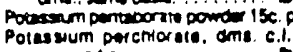

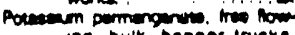
ing. bulk, hopper trueks

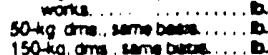

150kg ond com bets

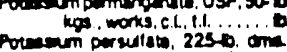
24.000 be or more. 10.0

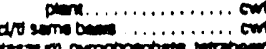

bet. C., L. mons. E. in$$
\text { raved. }
$$
1000

Pocencum roverto usp. orm 200 moma in

USP, powe. 300 o o din 2000 to

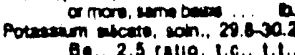
Be., 2.5 rallo, i.c. i.t.

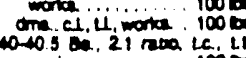

wo.5 21 row LC. LL.

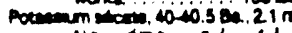

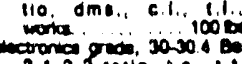
2.1.2.2 ralio, t.c ion.t.

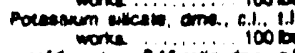
or 2 is rive at at

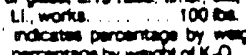

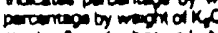

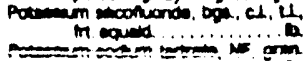
in pond

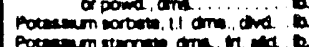

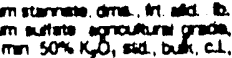

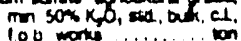

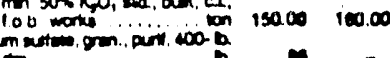
27002740

$4 \pi 0 n$

254

1.00

$\pi$

1.00
1.20

7250

4.75

1.22

124

1ew ins

20

$17.10 \quad 92.68$

27.10

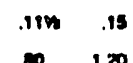

$200 \quad 120$

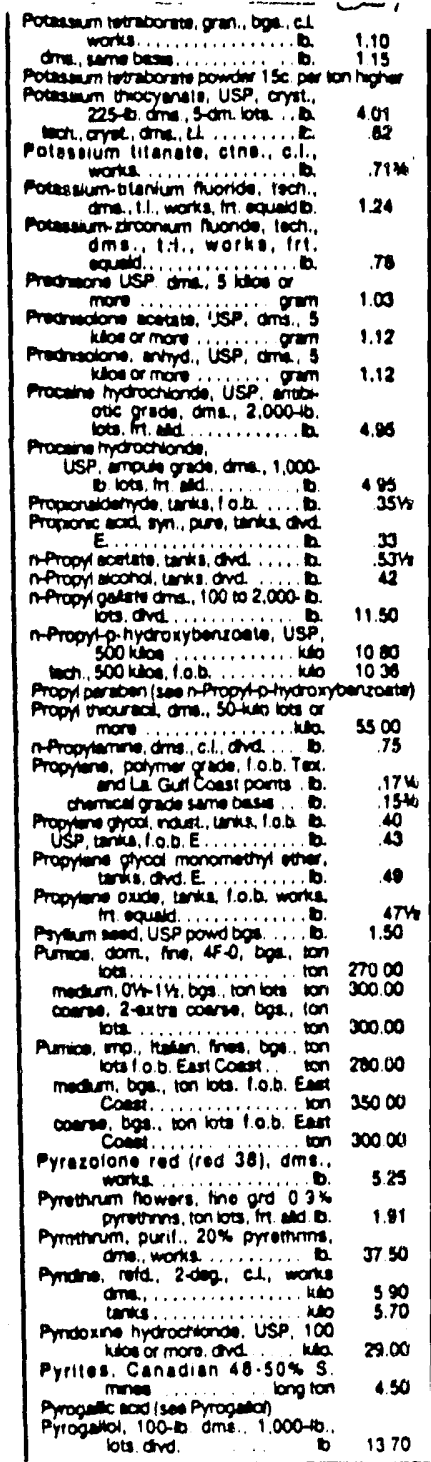

3400 and and $C L, U$. gren, 4000 in. 


\begin{tabular}{|c|c|c|}
\hline 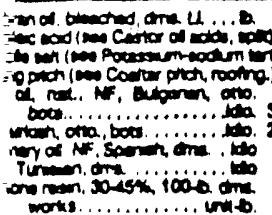 & 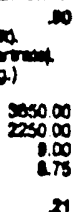 & 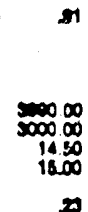 \\
\hline
\end{tabular}

1

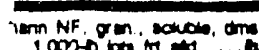
mis

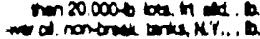

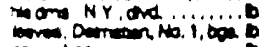

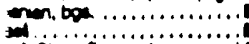

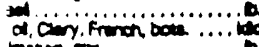
mancona........... r.00060

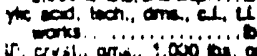

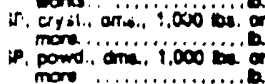

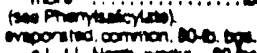

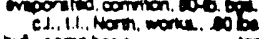

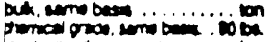

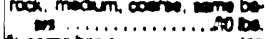

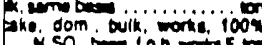

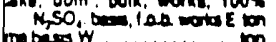

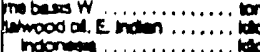

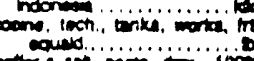

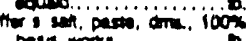
polemine hyorodionion, us

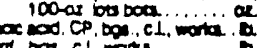

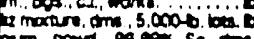

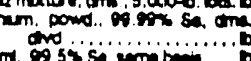

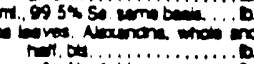
intion

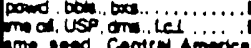

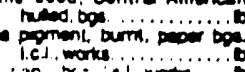

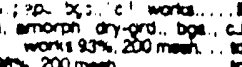

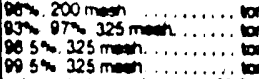

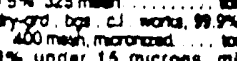
orouned 15 mictons. mi.

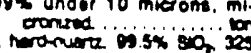

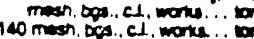
mons me nons............

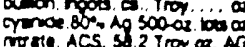

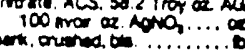

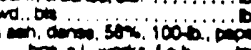

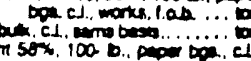

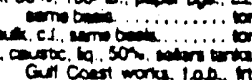

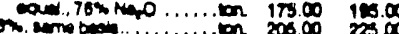

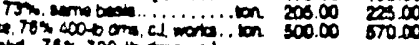

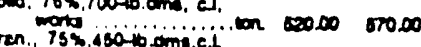

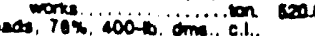

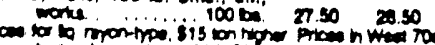

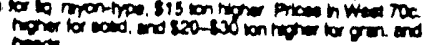

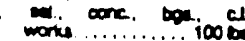

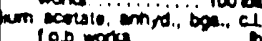

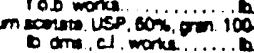

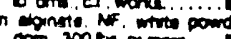
oom 300 be a mare Po. 1018 or moro, 1.0.

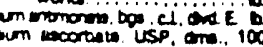

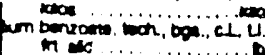

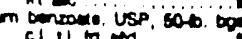

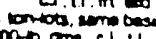

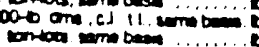

$200 \quad 270$

$2 \pi$

$\lim ^{\infty}=$

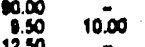
$1.07 \quad 1.10$ $129 \quad 1,1$

1.00100

10

$\infty$

$2 \pi$

$\infty_{\infty \infty \infty}^{\infty} \infty \infty \infty$

$\infty$

250

$214=$

13.0001500

.70

$\infty$ S1

100

$\begin{array}{rl}\pi \infty \infty & 200 \\ 300 & 50\end{array}$

3500

si 30 siso

$7200 \quad 730$

$100.00 \quad 100.00$

37.00

s.17

12000
30000
1.00
1.0

$\infty$ ars

$\operatorname{in} i=$

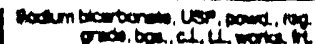

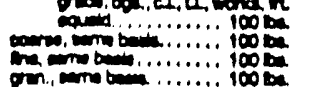
Den

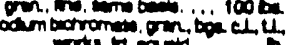

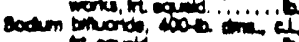

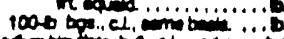

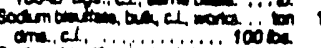
socm ching ind sonton

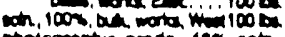
pholograptec ornow. W\% 100 th.

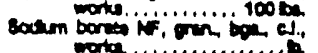

sodum boramation. po............ dis.

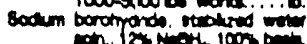

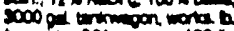

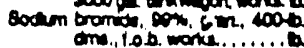

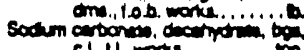

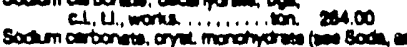

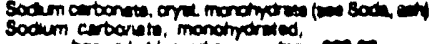

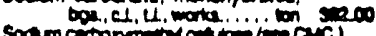

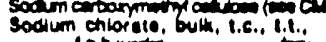

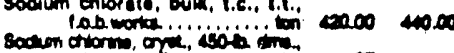

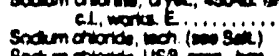

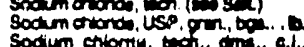

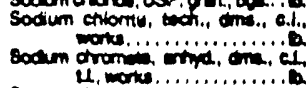

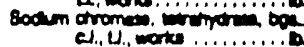

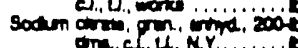

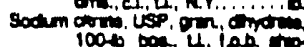
loob bow U. lab to

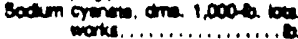

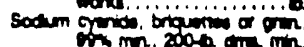
100 monta........ को

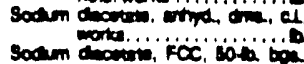

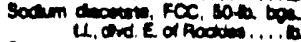

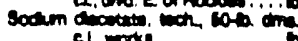

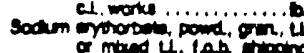
mow 4,106 .

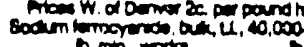

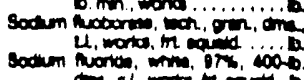

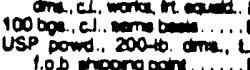

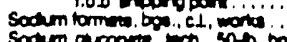

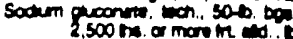

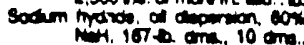

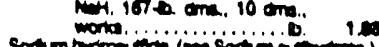

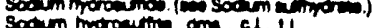

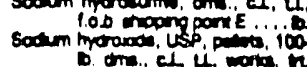

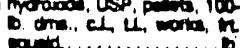

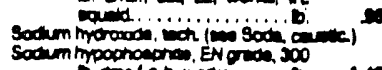

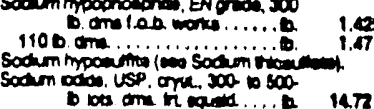

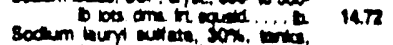

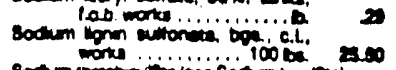

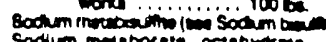

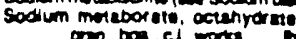

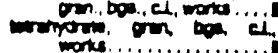

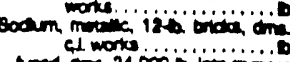

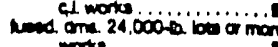

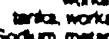

a.t.o.b. mpons on on

bor prom bo cilion in 1000

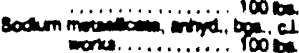

arect.......... 1006

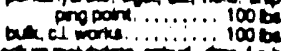

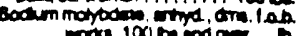

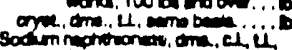

som to onk ....

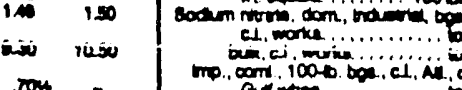

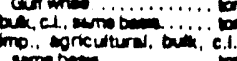

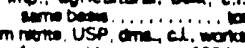

$n$

$\infty$

$\infty$

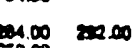

$20000 \times 100$

10.00
1700

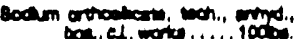

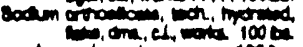

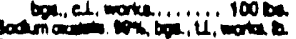
sodm 0 nection

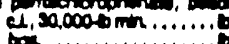
T20 soch on

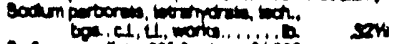

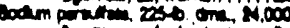

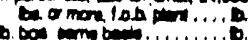

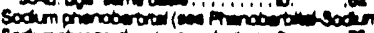

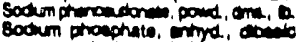

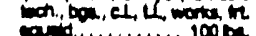

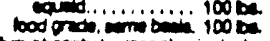

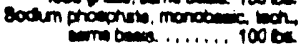
tood grod

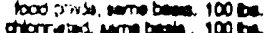
orrer tom

crys. 1000 orod, comp

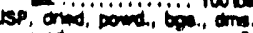

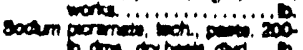

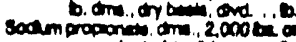

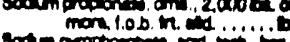

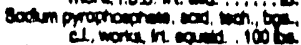

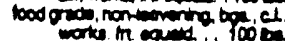

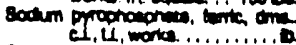

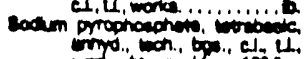
contsin naph 1000

bulk hopper cers camo

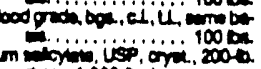

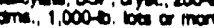

- $x_{200}$.

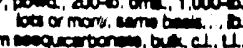

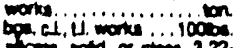
J.25 ratio, butk, c.lit.1.1.

1.052 .00 midi...

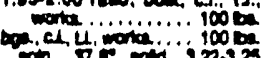
ratio. bulk, c.1. 1.1. at............. io be

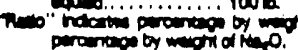

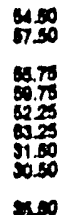

son

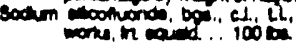

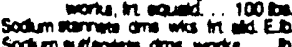

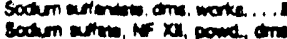

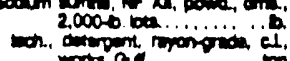

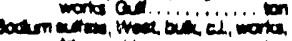

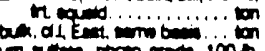
.10
600 ans 0125

30

4.75

0000

200

170.00

27.75

$\operatorname{man}_{210}$

mox on

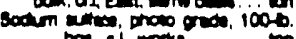

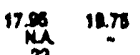

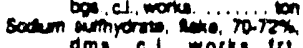

$$
\text { amic.... works. Irt. }
$$

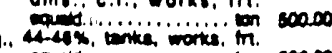

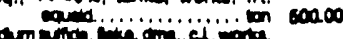
E.m.

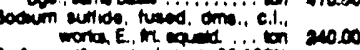

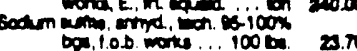

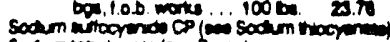

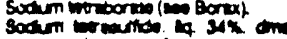

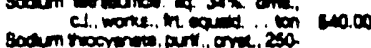

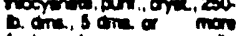

lob work .........

20

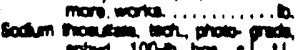
the $\log _{100}$

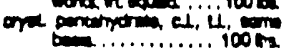

$\infty$

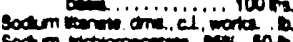

$14 x$

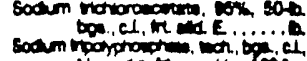

- noma nom

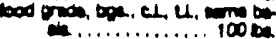

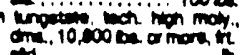

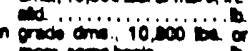

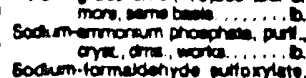
om $4,10 b$ monk - bos a mave mona

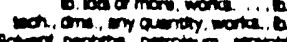
comote. b.t. $120^{\circ} .550^{2} \mathrm{~F}$. ind . 325

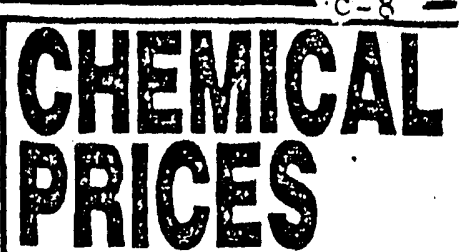

WEEK ENDING JUNE 6, 1986

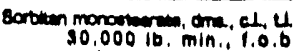

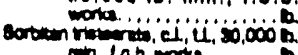

scronol, Ust, rop. $70 x$ a.....

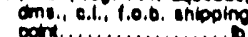

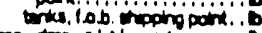

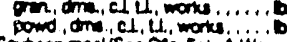

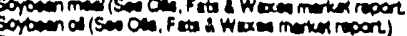

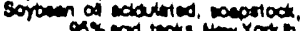

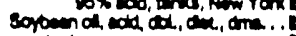

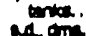

tonta

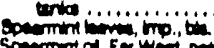

for notion. 


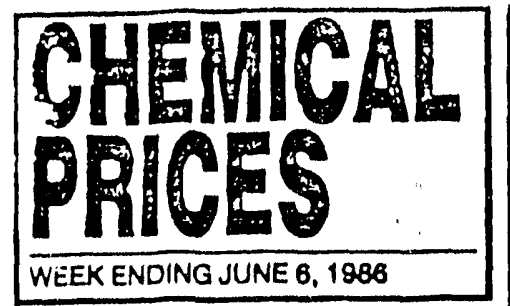

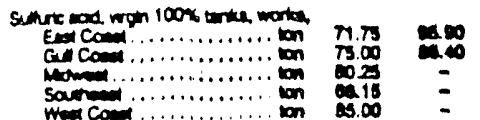

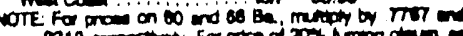

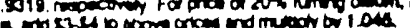

sefure cad am

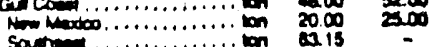

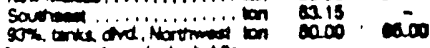

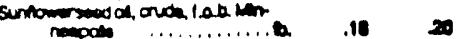

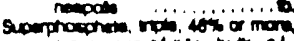

Fin.

a

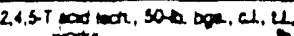

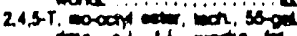
ams. C.L. If., works, It.

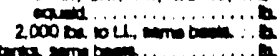

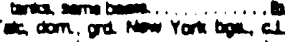

morts i............

al 400 nos

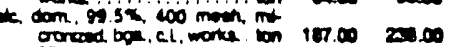

os mem. macronued bo

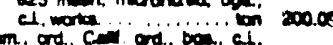

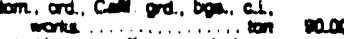

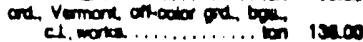

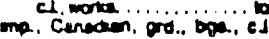

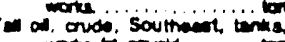

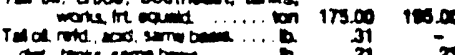

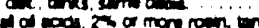

monk in and ...... b t

作

ow. tarm mod, wen., nom

and and and $\mathrm{cL}$.

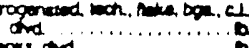

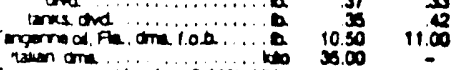

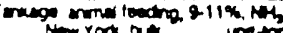

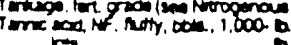

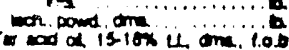

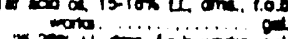

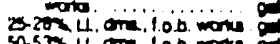

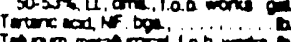

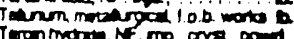

30 ko onm ion in $x$

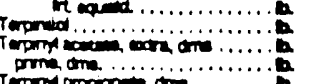

romomation on

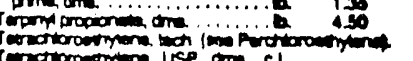

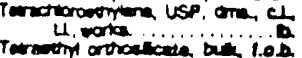

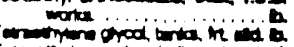

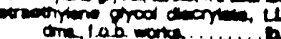

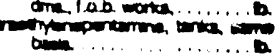

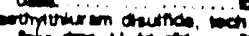

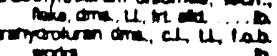

trata

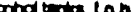

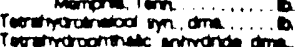

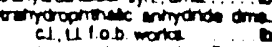

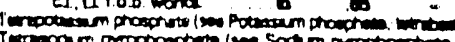
Tor

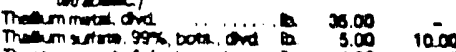

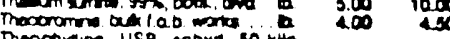

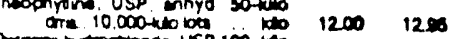

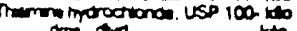

ara

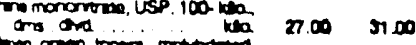

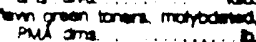

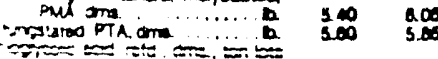

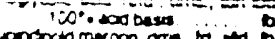

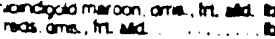

$2.50=$

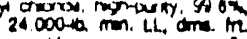

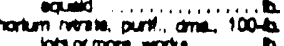
- Truas a more morke.......

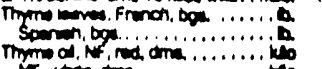

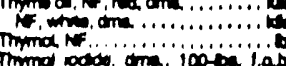

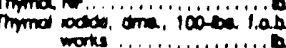

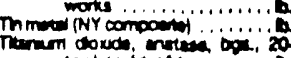

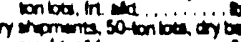
$=\pi$ m..............

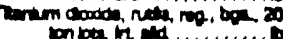

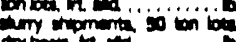

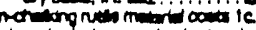

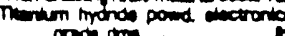

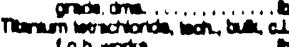

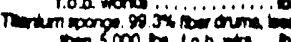
action Totim and 2000 on a mave....

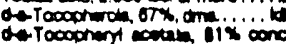

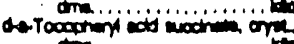

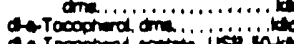

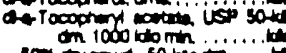

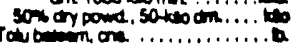

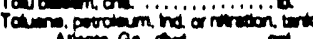
Aumen an and

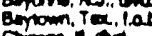

aromen and.

Demon prean

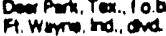

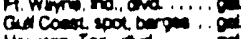

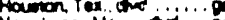

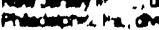

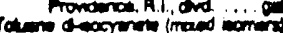
$\cos 24 \cos 2 \operatorname{sen} 2$ o com

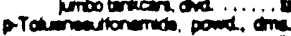

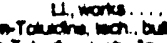

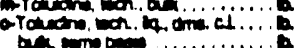

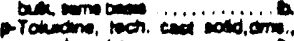
d. mote...............

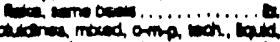
cllab wort

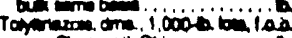

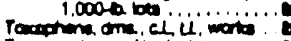

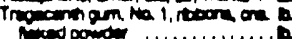

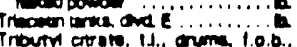

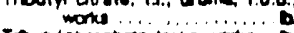

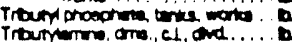

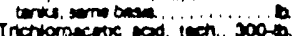

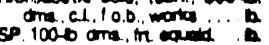

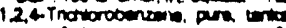

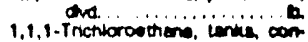

invere ove

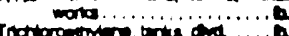

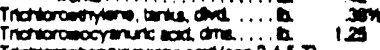

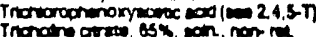

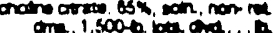

intorent phosphate, conter 1.0.6.

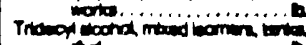

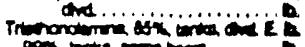

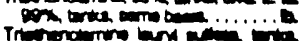

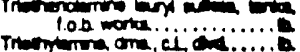

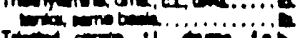

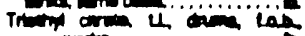

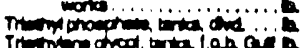

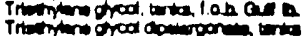

tob worke ............

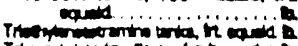

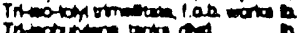

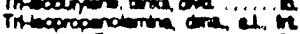

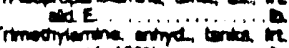

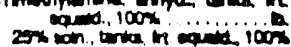

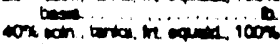

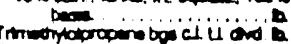

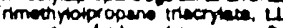

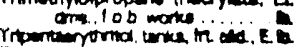

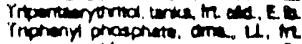

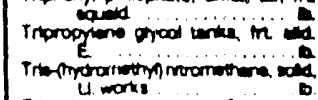

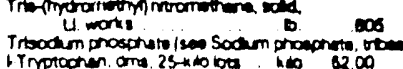

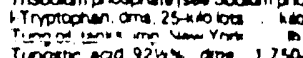

$\infty \pi$

$i_{i \infty \infty}^{100}$

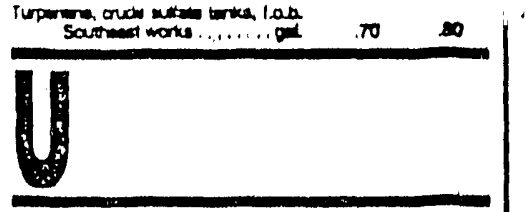

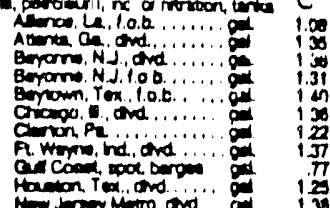

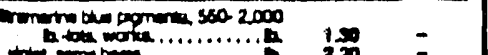

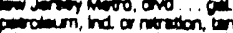

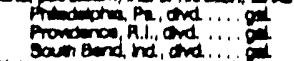

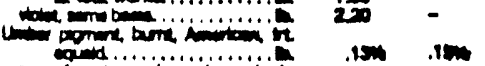

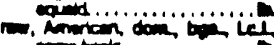

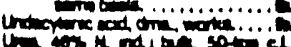

$\lim ^{100}$

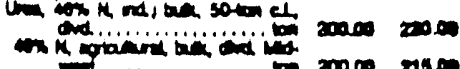

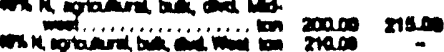

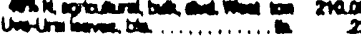

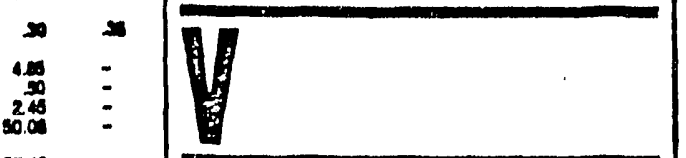

ic

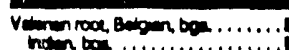

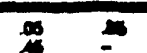

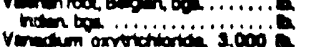

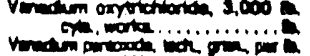

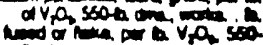

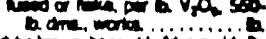

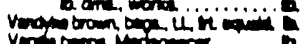

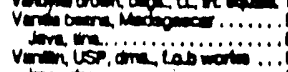
mand din

\section{ind}

intions

a i.............

n.....................

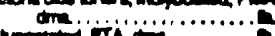

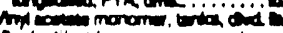

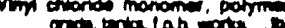

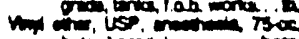

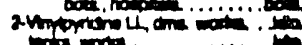

monarian

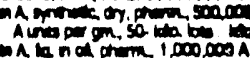

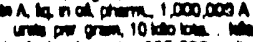

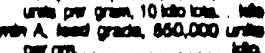

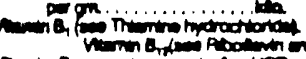

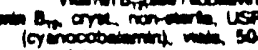

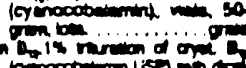

am propt 2sto on

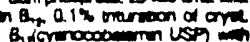

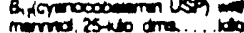

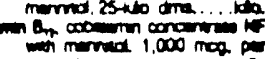

Tom itm in prom

conocon on

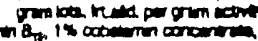

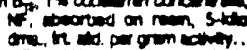

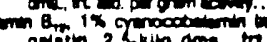

gutsin. 2.5-xite oms. in

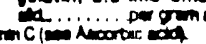

mino cractor of

nemine

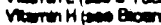

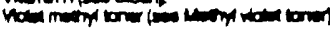

$\infty$

Yeremesta one

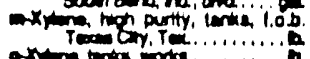

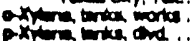

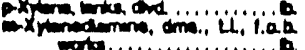

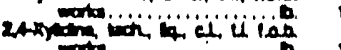

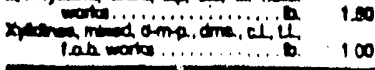

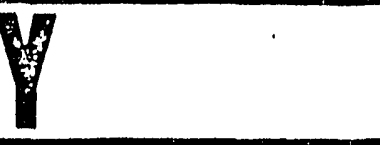

4 1n

25. 2 .

sim

3in

in

no

$\infty$

100

$-$

$2 \ln 200000$ bet

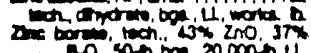

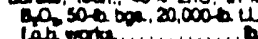

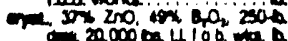

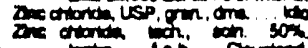

湓

曾

का

an 2 ans

13510

-

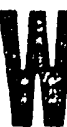

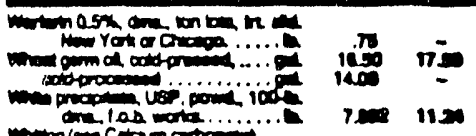

ming 100 cona

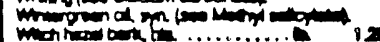

mon

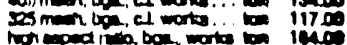

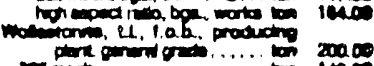

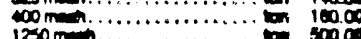

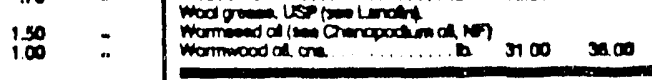

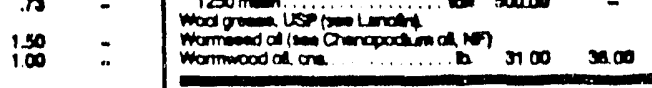

Conderici

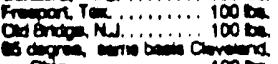

Concondicic.

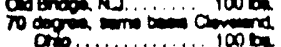

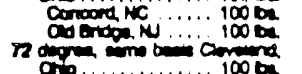

or.

arenosin.

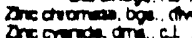

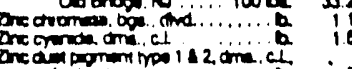

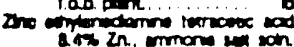

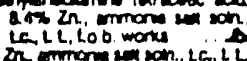

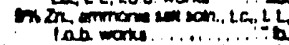

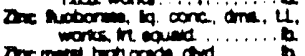

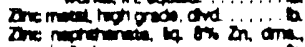

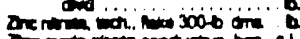

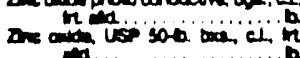

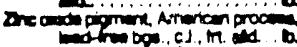

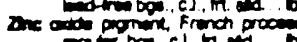

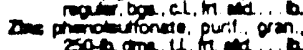

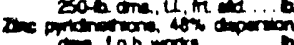

anclob

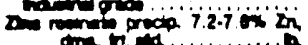

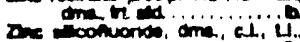

ar ispini

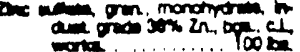

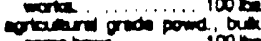

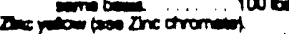

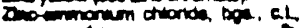

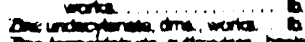

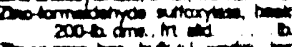

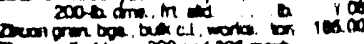

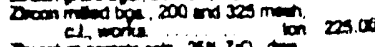

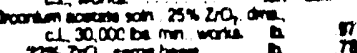

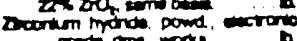

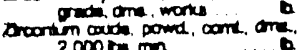

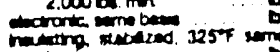




\section{Top 50 Chemicals Production Turned Back Up in 1987}

Output increased 5.5\% after slipping slightly in 1986 as organic chemicals moved up $5.5 \%$ and inorganic chemicals rebounded to rise $4.9 \%$

\section{Marc S. Reisch, C\&EN Now York}

A surge in exports of chemicals last year helped boost U.S. chemical output dramatically. According to C\&EN's annual ranking of the 50 largest-volume chemical products, total production in that group in 1987 increased 5.5\% from 1986 to 567 billion $\mathrm{lb}$. This marked a dra- matic improvement over 1986 when total production of the Top 50 chemicals dropped $0.9 \%$ from the previous year.

The recovery was all the more dramatic considering that last year imports continued to grow, but at a much slower rate than they did in previous years. A decline in the value of the dollar helped make U.S. chemicals more attractive to overseas purchasers, and thus U.S. export volume increased markedly.

Demand in the U.S. markets for chemicals did little to produce the dramatic improvement in overall chemical production. The housing market was virtually flat. The auto market was down moderately. How- ever, the U.S. farm efonomy began to stir and showed some small signs of improvement.

Among the largest-volume chemicals produced in the U.S., sulfuric acid continued to reign as king, with production last year totaling $\mathbf{7 7 . 5}$ billion lb, a 5.2\% increase from 1986. Nitrogen continued to rank a distant second, with production at 47.3 billion 1 b, down $2.7 \%$ from 1986 .

Organic chemicals, comprising $36 \%$ of the Top 50 , made a good showing, but that segment of the Top 50 did not do so well as it did in 1986. Production of those substances increased $5.5 \%$ from 1986 , compared with a $9.3 \%$ year-to-year increase in 1986. Between 1982 and

\section{About the Top 50 list of chemical products}

Government data, trade association figures, and industry estimates all go into preparing C\&EN's annual list of the Top 50 chemical products, ranked by production volume. The federal govornment is relied upon most heavily, but when government figures are not available, other sources, primarily trade associations, are used. Industry sources and C\&EN estimates are used only when other data are lacking.

Government data are not always accurate-they are only as good as the information that indlvidual companies report. But they are an objective measure of production extending back many years. Therefore, relatively accurate indications of growth can be made on a consistent basis.

At this time of year, C\&EN has access only to proliminary reports of production for 1987. When the government and trade associations issue their final reports, the outcome can be changed, sometimes dramatically. As a result, the production figures for ear- ller years that appear in the table on page 31 are different in some cases from those published in last year's Top 50 report. The final reports also can affect the rankings of chemicals. The 1986 rankings of 16 chemicals Ilsted in the table, for example, are different from those in the similar table published by C\&EN a year ago (CSEN, April 13, 1987, page 20).

The list itself covers production figures for the U.S. and includes chemicals produced for export. Candidates for the list include all basic, intermediate, and chemically homogeneous finished products. These range from chemical bullding blocks like ethylene and propylene to downstream products like vinyl acetate and ethylene glycol.

The roster also Includes basic inorganic chemicals, but does not include what C\&EN considers to be minerals, such as sah, gypsum, and sulfur. Lime is included because it is processed and has many chemical and industrial applications. Refractory (dead-burned) dolomite is excluded in the calculations of lime production.

In the organics list, such petrochernIcal feedstocks as ethane, butane, and propane are excluded arbitrarily because they are considered to be products of oll companies and because they have many nonchemical uses.

There are other gray areas besides lime and petroctiomical foedstocks. For example, the basic aromatics-benzene, toluene, and xylene-are included. Admittedly, this makes the list less pure chemically.

Production figures are published by the government and trade associations In a variety of units-millions of pounds, thousands of tons, billions of cublc foet, millions of gallons, metric tons. To provide an accurate ranking and to make comparison of production volumes easier, C\&EN not only gives production in cornmon units but converts production to blllions of pounds as well. 
Top 50 chemicals production totaled 567 billion lb in 1987

\begin{tabular}{|c|c|c|c|c|c|c|c|c|c|c|}
\hline \multicolumn{2}{|c|}{ Runk } & \multirow[b]{2}{*}{11} & \multicolumn{2}{|c|}{ allions of to } & \multicolumn{2}{|c|}{ Common unites } & \multicolumn{4}{|c|}{ A wercope ennual prowth } \\
\hline 1007 & $9060^{\circ}$ & & 1007 & 1066 & 1087 & 1066 & $1008-87$ & $1925-68$ & $1902-87$ & $1077-87$ \\
\hline 1 & 1 & Sulfurle acld & 77.49 & 73.64 & $38,748 \pi$ & $36,822 \pi$ & $5.2 \%$ & $-7.1 \%$ & $3.1 \%$ & $1.1 \%$ \\
\hline 2 & 2 & Nitrogen & 47.32 & 48.62 & $653 \mathrm{bcl}$ & $671 \mathrm{bct}$ & -2.7 & 2.4 & 6.2 & 8.5 \\
\hline 3 & 4 & Ethylene & 34.99 & 32.81 & $34,992 \mathrm{mp}$ & $32,811 \mathrm{mp}$ & 6.6 & 9.9 & 7.4 & 4.5 \\
\hline 4 & 6 & Ammonia & 32.32 & 28.01 & $16,161 \mathrm{tt}$ & $14,005 \mathrm{tt}$ & 15.4 & -19.1 & 0.5 & -0.3 \\
\hline 5 & 3 & Oxygen & 32.28 & 33.03 & $390 \mathrm{bcl}$ & 398 bcl & -2.3 & 1.5 & 2.2 & 0.2 \\
\hline$\theta$ & 5 & Limec & 30.36 & 29.67 & $15,182 \pi$ & $14,834 \mathrm{tt}$ & 2.3 & -6.1 & 1.5 & -2.2 \\
\hline 7 & 7 & Sodlum hydroxide & 23.03 & 21.38 & $11,517 \mathrm{tt}$ & $10,681 \mathrm{H}$ & 7.7 & -1.8 & 4.2 & 0.9 \\
\hline 8 & 8 & Chlorine & 21.83 & 20.87 & $10,863 \mathrm{tt}$ & $10,436 \mathrm{H}$ & 5.0 & 0.4 & 3.6 & 0.5 \\
\hline 9 & 9 & Phosphoric acld & 20.95 & 18.41 & $10,473 \pi$ & $8,206 \mathrm{tt}$ & 13.8 & -12.5 & 4.9 & 2.8 \\
\hline 10 & 10 & Propylene & 18.53 & 17.34 & $18,527 \mathrm{mp}$ & $17,343 \mathrm{mp}$ & 6.8 & 16.5 & 8.1 & 6.3 \\
\hline 11 & 11 & Sodlum carbonaled & 17.78 & 16.88 & $8,891 \mathrm{tt}$ & $8,438 \pi$ & 6.4 & -1.8 & 2.6 & 5.5 \\
\hline 12 & 14 & Urea* & 14.86 & 12.06 & $7,431 \mathrm{t}$ & $6,029 \pi$ & 23.3 & -9.7 & 2.8 & 6.6 \\
\hline 13 & 13 & Nitric acld & 14.20 & 13.12 & $7,102 \pi$ & $6,562 \mathrm{tt}$ & 8.2 & -10.9 & -0.8 & -0.9 \\
\hline 14 & 12 & Ethytene dichloride & 13.81 & 14.53 & $13,805 \mathrm{mp}$ & $14,529 \mathrm{mp}$ & -5.0 & 20.1 & 12.6 & 5.6 \\
\hline 15 & 15 & Ammonlum nitrate' & 12.83 & 11.11 & $6,416 \mathrm{H}$ & $5,556 \mathrm{tt}$ & 15.5 & -18.0 & -2.0 & -1.1 \\
\hline 16 & 16 & Benzene & 11.67 & 10.23 & $1,585 \mathrm{mg}$ & $1,389 \mathrm{mg}$ & 14.1 & 8.9 & 8.5 & 1.1 \\
\hline 17 & 17 & Carbon dloxides & 8.84 & 8.77 & $4,922 \pi$ & $4,883 \pi$ & 0.8 & -2.3 & 5.2 & 9.6 \\
\hline 18 & 18 & Elhylbenzene & 8.41 & 8.92 & $9,409 \mathrm{mp}$ & $8,915 \mathrm{mp}$ & 5.5 & 20.7 & 7.2 & 5.0 \\
\hline 19 & 19 & VInyl chlorlde & 8.23 & 8.42 & $8,230 \mathrm{mp}$ & $8,415 \mathrm{mp}$ & -2.2 & -11.1 & 10.9 & 3.8 \\
\hline 20 & 21 & Torephthalic acloth & 8.11 & 7.68 & $8,110 \mathrm{mp}$ & $7,684 \mathrm{mp}$ & 5.5 & 18.4 & 10.9 & 1.2 \\
\hline 21 & 20 & Styrene & 8.09 & 7.84 & $8,090 \mathrm{mp}$ & $7,838 \mathrm{mp}$ & 3.2 & 2.8 & 6.4 & 2.5 \\
\hline 22 & 22 & Mothanol & 7.29 & 7.33 & $7,292 \mathrm{mp}$ & $7,327 \mathrm{mp}$ & -0.5 & 46.5 & -0.7 & 1.6 \\
\hline 23 & 25 & Toluene' & 6.73 & 5.82 & $928 \mathrm{mg}$ & 802 mg & 15.7 & 14.7 & 5.4 & -0.7 \\
\hline 24 & 24 & Formaldehydel & 6.08 & 5.89 & $6,077 \mathrm{mp}$ & $5,885 \mathrm{mp}$ & 3.3 & 5.0 & 4.8 & 1.1 \\
\hline 25 & 26 & Xylene & 5.72 & 5.55 & $795 \mathrm{mg}$ & $771 \mathrm{mg}$ & 3.1 & 4.5 & 3.9 & 1.0 \\
\hline 26 & 23 & Ethylene oxide & 5.62 & 5.94 & $5,623 \mathrm{mp}$ & $5,943 \mathrm{mp}$ & -5.4 & 9.4 & 2.4 & 3.0 \\
\hline 27 & 27 & pixylene & 5.15 & 5.00 & $5,152 \mathrm{mp}$ & $4,995 \mathrm{mp}$ & 3.1 & 4.5 & 9.9 & 5.9 \\
\hline 28 & 28 & Hydrochloric acld & 4.99 & 4.83 & $2,495 \pi$ & $2,413 \pi$ & 3.4 & -14.0 & 0.4 & -0.2 \\
\hline 29 & 29 & Ethylene glycol & 4.52 & 4.76 & $4,515 \mathrm{mp}$ & $4,759 \mathrm{mp}$ & -5.1 & 13.9 & 0.9 & 3.1 \\
\hline 30 & 30 & Ammonlum sulfale & 4.37 & 4.17 & $2.183 \pi$ & $2,086 \mathrm{tt}$ & 4.7 & -0.3 & 4.3 & 0.8 \\
\hline 31 & 31 & Cumene & 4.15 & 3.70 & $4,151 \mathrm{mp}$ & $3,695 \mathrm{mp}$ & 12.3 & 10.5 & 8.6 & 4.3 \\
\hline 32 & 41 & Mothyl lert-butyl etherk & 3.37 & 2.24 & $3,372 \mathrm{mp}$ & $2,237 \mathrm{mp}$ & 50.7 & 18.3 & 32.6 & $\mathrm{~nm}$ \\
\hline 33 & 33 & Phenol' & 3.24 & 2.92 & $3,241 \mathrm{mp}$ & $2,921 \mathrm{mp}$ & 11.0 & 5.2 & 9.9 & 4.3 \\
\hline 34 & 32 & Acollic scid & 3.23 & 2.93 & $3,227 \mathrm{mp}$ & $2,931 \mathrm{mp}$ & 10.1 & 1.2 & 3.3 & 2.7 \\
\hline 35 & 35 & Butadienem & 3.00 & 2.59 & $3,002 \mathrm{mp}$ & $2,593 \mathrm{mp}$ & 15.8 & 10.8 & 8.4 & -1.5 \\
\hline 35 & 34 & Potashn & 3.00 & 2.65 & $1,360 \mathrm{tmt}$ & $1.202 \mathrm{tmt}$ & 13.1 & -7.3 & -5.3 & -4.6 \\
\hline 37 & 35 & Carbon black & 2.72 & 2.59 & $2,724 \mathrm{mp}$ & $2,585 \mathrm{mp}$ & 5.4 & 0.5 & 3.4 & -1.0 \\
\hline 38 & 37 & Propylene oxide & 2.61 & 2.48 & $2,608 \mathrm{mp}$ & $2,480 \mathrm{mp}$ & 5.2 & 3.3 & 9.2 & 3.6 \\
\hline 39 & 39 & Acrylonitrlle & 2.55 & 2.31 & $2,551 \mathrm{mp}$ & $2,314 \mathrm{mp}$ & 10.2 & -1.4 & 4.6 & 5.3 \\
\hline 40 & 40 & VInyl acetale & 2.51 & 2.25 & $2,505 \mathrm{mp}$ & $2,249 \mathrm{mp}$ & 11.4 & 6.5 & 6.0 & 5.4 \\
\hline 41 & 38 & Aluminum sulfate & 2.45 & 2.44 & $1,223 \mathrm{tt}$ & $1,222 \pi$ & 0.1 & -3.6 & 1.2 & 0.2 \\
\hline 42 & 42 & Cyclohexane & 2.25 & 2.07 & $2,250 \mathrm{mp}$ & $2,071 \mathrm{mp}$ & 8.6 & 25.0 & 12.0 & 0.3 \\
\hline 43 & 43 & Acetono & 2.08 & 1.94 & $2,082 \mathrm{mp}$ & $1,936 \mathrm{mp}$ & 7.5 & 8.3 & 4.2 & 1.1 \\
\hline 44 & 44 & Tilanlum dloxide & 1.90 & 1.86 & $952 \mathrm{n}$ & $931 \mathrm{tt}$ & 2.3 & 8.3 & 7.7 & 2.9 \\
\hline 44 & 45 & Sodium sillicate & 1.90 & 1.57 & $948 \pi$ & $786 t$ & 20.6 & 9.0 & 7.4 & 2.4 \\
\hline 46 & 47 & Sodium sulfate ${ }^{\circ}$ & 1.61 & 1.55 & $805 \mathrm{tt}$ & $775 \pi$ & 3.9 & -6.3 & -1.4 & -4.2 \\
\hline 47 & 48 & Adiple acld & 1.57 & 1.52 & $1.572 \mathrm{mp}$ & $1,522 \mathrm{mp}$ & 3.3 & 4.7 & 6.3 & 0.4 \\
\hline 48 & 46 & Calclum chloridep & 1.55 & 1.56 & $773 \mathrm{nt}$ & $780 \mathrm{H}$ & -0.9 & -2.6 & -2.0 & -4.3 \\
\hline 49 & 49 & Isopropyl alcohol & 1.31 & 1.28 & $1,313 \mathrm{mp}$ & $1,275 \mathrm{mp}$ & 3.0 & 3.2 & -1.0 & -3.8 \\
\hline 50 & 50 & Caprolactam & 1.16 & 0.85 & $1,161 \mathrm{mp}$ & $850 \mathrm{mp}$ & 36.6 & -21.5 & 7.9 & 4.1 \\
\hline & $\begin{array}{l}\text { TAL OR: } \\
\text { TAL IR: } \\
\text { ANS TC }\end{array}$ & $\begin{array}{l}\text { LHIES } \\
\text { RGATICS } \\
\text { AL }\end{array}$ & $\begin{array}{l}201.85 \\
364.83 \\
566.68\end{array}$ & $\begin{array}{l}189.17 \\
347.74 \\
536.91\end{array}$ & & & $\begin{array}{l}5.5 \% \\
4.9 \% \\
5.5 \%\end{array}$ & $\begin{array}{r}9.3 \% \\
-5.7 \% \\
-0.9 \%\end{array}$ & $\begin{array}{l}7.1 \% \\
2.3 \% \\
4.8 \%\end{array}$ & $\begin{array}{r}2 \\
-1 \\
1\end{array}$ \\
\hline
\end{tabular}

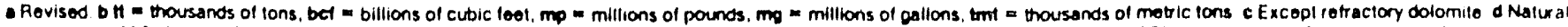

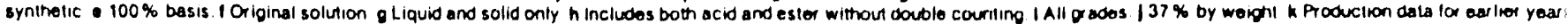
avaliable I Syntholic only. $m$ Rubber or ade. $n \mathrm{~K}, \mathrm{O}$ basis o High and low purity. P Solid and liquid $\mathrm{mm}=$ nol meaninglul 
1987, production of organic chemicals among the Top 50 increased $7.1 \%$ a year. Over the long term, however, their output has grown at a much slower pace. Between 1977 and 1987, output of organic chemicals among the Top 50 has grown only at a rate of $2.7 \%$ a year.

However, the inorganic segment of the Top 50 made a dramatic recovery in 1987. Production increased $4.9 \%$, following a $5.7 \%$ decline in 1986. Within that segment, output of the major fertilizer chemicals was up-including phosphoric acid, up $14 \%$; urea, up $23 \%$; and potash, up $13 \%$. Other big-volume inorganics also showed improvements. $\mathrm{Ni}$ tric acid production increased $8.2 \%$, and ammonium nitrate production increased $16 \%$.

Of the Top 50 chemicals, production of 42 of them increased in 1987. By contrast, production of only 19 increased in 1986. Although total production of the Top 50 chemicals, at 567 billion lb, was up $5.5 \%$ from 1986, it was down 1.4\% from the Top 50 historical high of 575 billion lb in 1979. The 1987 production level was $22 \%$ higher than the decade-low production level of 464 billion lb registered in 1982.

For the Top 50 group, composite output increased at a compound annual rate of $4.8 \%$ between 1982 and 1987. However, indicative of longterm growth. Top 50 production grew at an average annual rate of 1.3\% between 1977 and 1987.
As a group, organic chemicals outperformed the inorganics, however. Showing the largest produc. tion increase on the organics side was methyl tert-butyl ether. Production of that chemical was up $51 \%$ to 3.37 billion $1 \mathrm{~b}$. The gain pushed that chemical to 32 nd place in 1987 from 41 st place in 1986.

Next in terms of percentage gains among the organics was caprolactam, up $37 \%$ to 1.16 billion $l b$. The increase gained the chemical's entry into the Top 50 at 50 th place in 1987. It did not appear on the list for 1986 (C\&EN, April 13, 1987, page 20).

Also up appreciably in terms of percentage gains viere urea, with output up $23 \%$ to 14.9 billion $1 \mathrm{~b}$ following a $9.7 \%$ decline in 1986 ; butadiene, up $16 \%$ to 3.0 billion $\mathrm{lb}$; toluene, up $16 \%$ to 6.73 billion $\mathrm{lb}$; and benzene, up $14 \%$ to 11.7 billion $1 b$.

Not all the organics gained, however. The biggest decreases came from ethylene oxide, whose production was down $5.4 \%$ from the previous year, and ethylene glycol, down $5.1 \%$.

For inorganic chemicals, 1987 production was led by sodium silicate, up nearly $21 \%$ from 1986 to 1.90 billion lb. Sodium silicate also led the pack in production growth in 1986, when production grew $9.0 \%$. Also showing very good production increases in 1987 were ammonium nitrate, up $16 \%$ to 12.8 billion
Ib following an $18 \%$ decline the previous year; and ammonia, up $15 \%$ to 32.3 billion $1 b$ following a $19 \%$ decline in 1986.

Other large-volume inorganic chemicals that had large swings in production last year were phosphoric acid, up $14 \%$ to nearly 21 billion lb, following a $13 \%$ decline a year earlier; and potash, up $13 \%$ to 3.0 billion $\mathrm{lb}$ in 1987 following a $7.3 \%$ decline in 1986.

Over the past five years, 43 of the Top 50 chemicals have registered increases in production. Leading in individual increases over the fiveyear span was methyl tert-butyl ether, whose production grew at an annual compound rate of almost $33 \%$. Next were ethylene dichloride, up about $13 \%$ annually for the fiveyear period; cyclohexane, up $12 \%$ a year; vinyl chloride, up $11 \%$ a year; and terephthalic acid, also up $11 \%$ a year.

On the downside of production, leading the products with the largest individual decreases over the five-year period was potash, whose output fell at a compound annual rate of $5.3 \%$. Other chemicals registering decreases over the five-year period were ammonium nitrate, down $2.0 \%$ a year; calcium chloride, also down $2.0 \%$ a year; sodium sulfate, down $1.4 \%$ a year; and isopropyl alcohol, down $1 \%$ a year.

Looking at growth over the past 10 years, 39 of the Top 50 chemicals have recorded overall production

\section{Production of Top 50 chemicals is on the upswing}
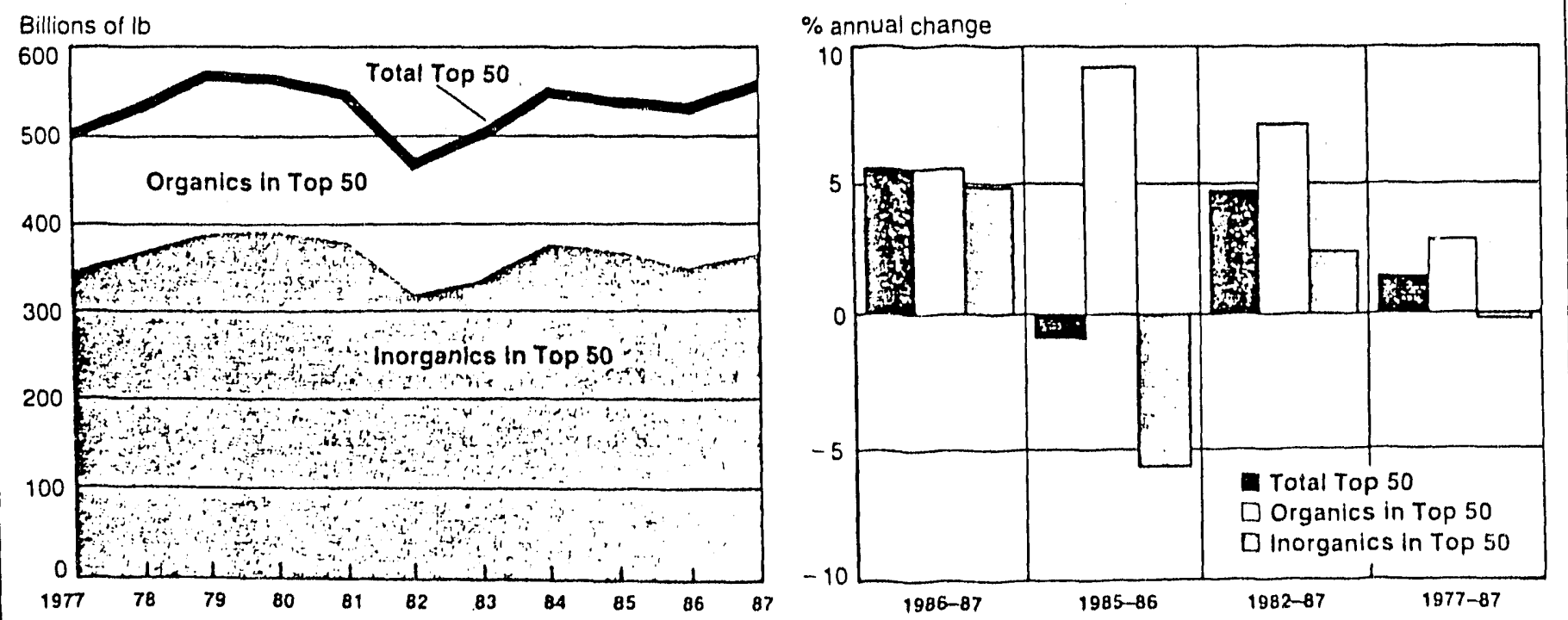
increases. The best longuterm performer has been carbon dioxide, whose output grew at an annual compound rate of $9.6 \%$ during this period. Production of nitrogen also grew at a remarkable rate of $8.5 \%$. Other chemicals with sizable growth rates were urea, up $6.6 \%$ a year, and propylene, up $6.3 \%$ per year.

Potash registered the greatest average annual rate of decline over the past 10 years. Its output has fallen at a compound annual rate of $4.6 \%$. Other products with shrinking output were calcium chloride, down $4.3 \%$ a year; sodium sulfate, down $4.2 \%$ a year; isopropyl alco- hol, down $3.8 \%$ a year; and lime, down $2.2 \%$ a year.

The group comprising the 10 largest chemical commodities in terms of production was the same in 1987 as it was in 1986. Some commodities within that group, however, switched places in ranking. Ethylene, for example, which ranked third in volume in 1987, was fourth in terms of production in 1986. Ammonia moved up to fourth place from sixth place a year earlier. Oxygen moved down to fifth place from third place in 1986, and lime slipped a notch to sixth place after ranking fifth place a year earlier.
There was a good deal of ras shifting thoughout the rest of $t$ list. In all, 21 of the chemicals $t$ ther moved up or down in tl rankings.

Besides the rise for ethylene at ammonia and the fall of oxygen as lime already noted, there werc of er significant changes. Some upwa movements included methy! if butyl ether, with its $51 \%$ increase production in 1987, which jump: to 32 nd place from 41 st in 198 Other large changes included ure which jumped to 12 th place fro $14 \mathrm{th}$, and toluene, which moved 1 to 23 rd place from 25 th.

\section{Polymer output records fifth consecutive annual rise}

Overall production of plastics, synthetic fibers, and synthetic rubber polymers reached a record high of 57 billion $\mathrm{lb}$ in 1987. The growth marked the fifth consecutive annual increase for the product group, lifting the output total $9.1 \%$ above the 1986 record.

Plastics, which account for more than two thirds of the polymer group production totals, continued their buoyant growth in 1987. Production was up $9.9 \%$ from 1986. The strongest growth among plastics was registered by the thermoplastic resins, up $10 \%$. Of such resins, polypropylene continued to show the highest growth, up 14\%; followed by high-density polyethylene, up $12 \%$; polyvinyl chloride and copolymers, up 9.9\%; low-density polyethylene, up $8.3 \%$; and polystyrene, up $7.7 \%$.

By comparison, output of thermosetting resins grew $7.4 \%$ in 1987. Melamine resins made a spectacular recovery in 1987, up 23\%, following a dismal performance a year earlier when production dropped $9.9 \%$. Production last year at 212 million $1 \mathrm{~b}$ marked a decade high for melamine resins production. The previous high was in 1984, when industry produced 210 million $1 \mathrm{~b}$ of the resins.

Showing good though less re- markable gains were epoxy resin up $8.8 \%$ in 1987; urea resins, u $8.7 \%$; polyesters, up $7.8 \%$; and ph. nol and other tar acid resins, $u$ $5.4 \%$.

For the five-year period betwee 1982 and 1987, the plastics segmei grew at an annual compound ra of $8.5 \%$. For the 10 -year period $b$ tween 1977 and 1987, plastics gre at an annual compound rate of $5.4 \%$

Synthetic rubber output increase $8.4 \%$ in 1987 . Production of 4.8 bi lion lb last year matched the 4 . billion high of 1984 , but the cat gory's output is still running 17 below the decade high of $5.6 \mathrm{bi}$ lion lb in 1979.

\section{Output of plastics, synthetic fibers, and synthetic rubbers continued to climb in 1987}
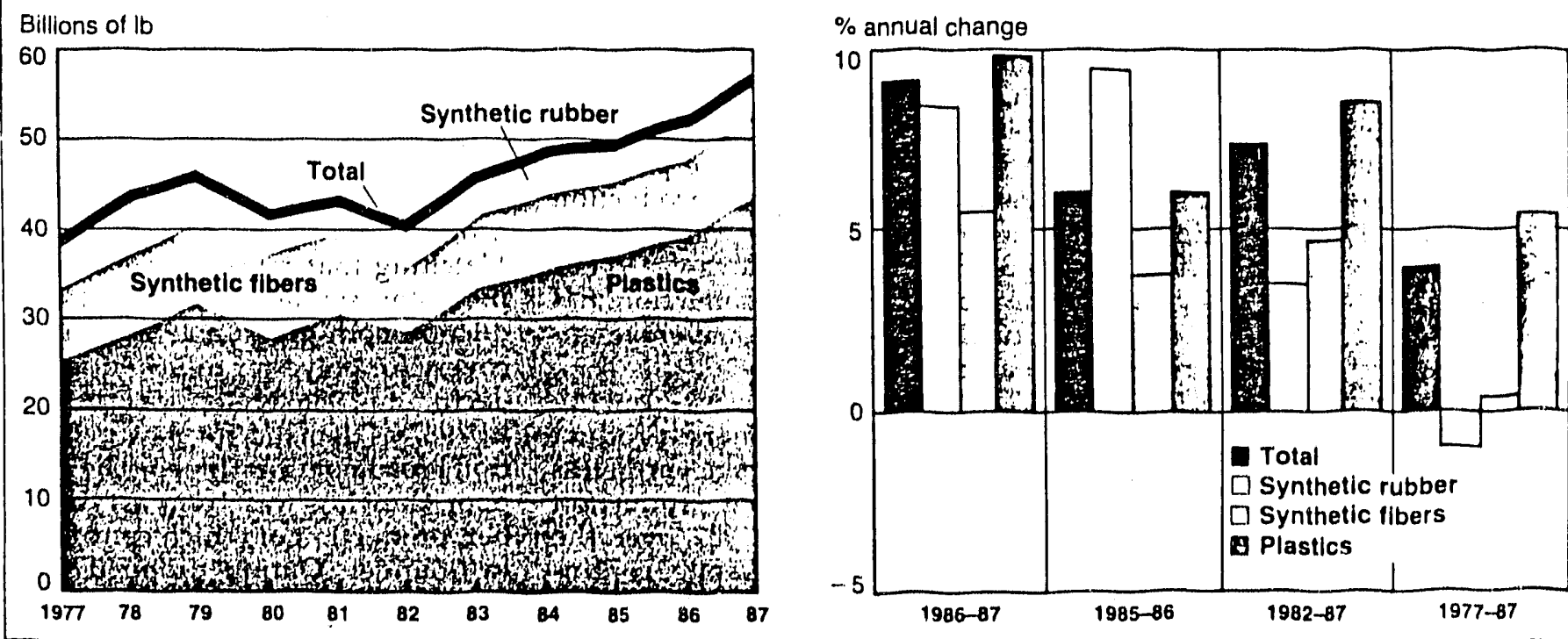
Total polymer production exceeded 57 billion lb last year

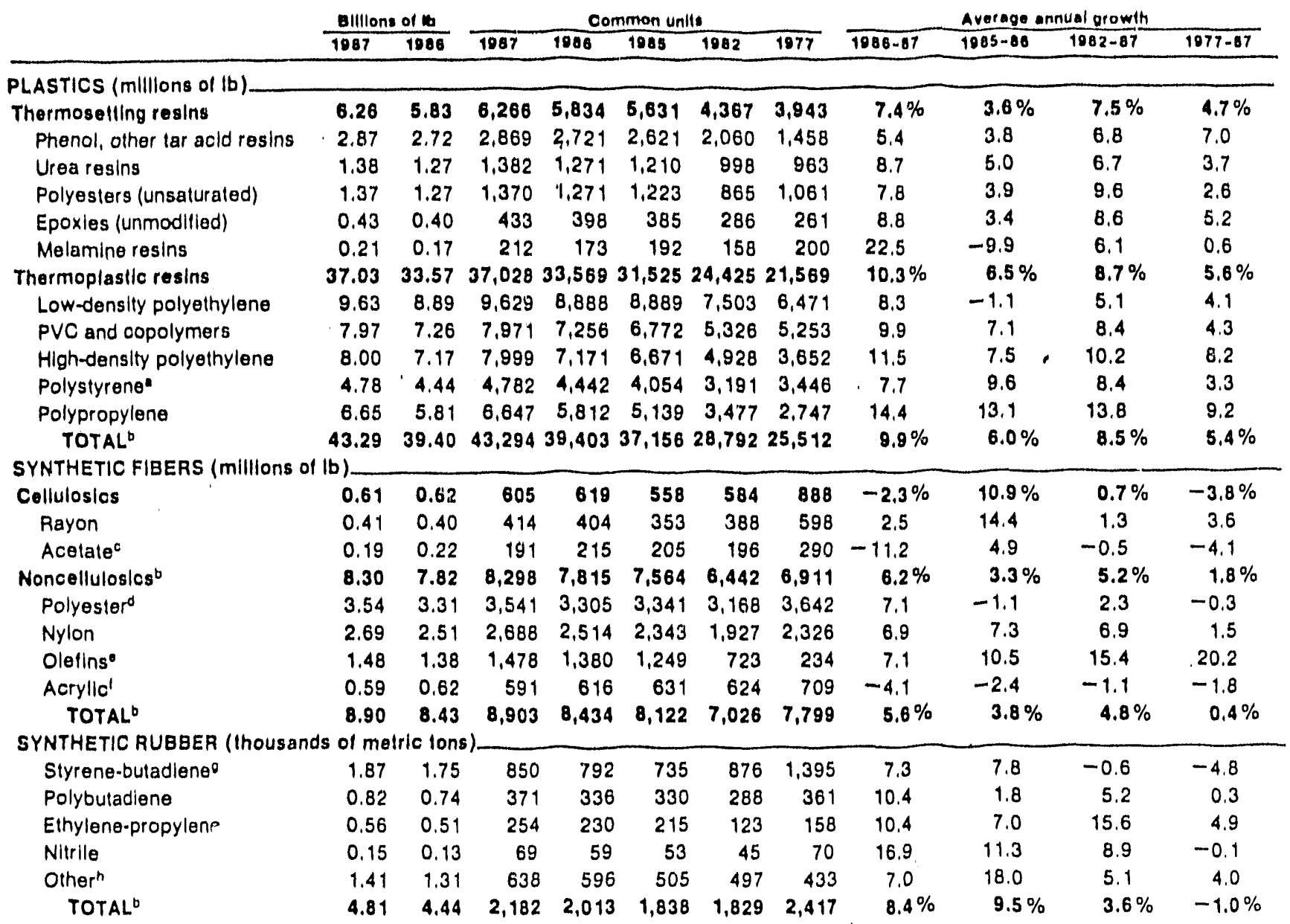

- No longer includes acrilonitrile buladiene-stylene or styrene-acrylonilfle resins: historical data are restated. b Tolals are tor those products listed. Tolals may nol add because ol rounding c includes diacelale and iriacelate yarn. but does nol include cigatette low Beginning with 1985, includes rayon yarn d Exciudes aramid atter 1982 - Includes ole lin film, olefin liber, spuctbonded polypropylene, and viliyon I Includes modacrylic o Excludes high-styr eno lalex. h Beginning with 1985, includes neoprene; historical dala are ieslaled. Also includes butyl: polyisoprene; chlorosullonaled polyethylene; polyisobutylene; and acrilo. fluoro, and silicone elastomers. Sources: Society of the Plaslics Indusiry. Texile Economics Bureau. Rubber Manufacturers Association

All segments of the synthetic rubber category registered increases in production in 1987. Nitrile rubber showed the largest rise at $17 \%$, following a 11\% increase in 1986. Both polybutadiene and ethylene-propylene rubber production grew $10 \%$ in 1987. The increase in polybuta. diene production was the most remarkable, following a $1.8 \%$ increase in 1986. Ethylene-propylene rubber's 1987 growth follows a 1986 growth of $7.0 \%$.

Production growth of styrenebutadiene rubber slowed in 1987 to $7.3 \%$ from a $7.8 \%$ growth rate in 1986. Also putting in a showing that was not quite as good as the year earlier were the synthetic rubber products reported as a group by the Rubber Manufacturers Association: neoprene; butyl; polyisoprene; chlo- rosulfonated polyethylene; polyisobutylene; and acrylo, fluoro, and silicone elastomers. Production of that group grew $7.0 \%$ in 1987 , compared with $18 \%$ in 1986.

Over the past five years, the synthetic rubber category has not grown so rapidly as it has in the past two years. Synthetic rubber production has grown at an average annual rate of $3.6 \%$ over the past five years. For the past 10 years, production has actually declined at an average annual rate of $1.0 \%$.

Though still the slowest-growing of the entire polymers product group, synthetic fibers nevertheless recorded a respectable production increase of $5.6 \%$ in 1987 over the year-earlier level. Despite continued pressure from imported textiles, noncellulosics showed the most impressive gains. However, ceilu. losics declined in part because of discontinuation of U.S. triacetate production.

Output of noncellulosics regiorded the best gain, rising $6.2 \%$ in 1987 . The group accounted for mote than 90\% of total fiber producition last year. Olefins continued lo lead in growth; they werc up $7.1 \%$ in 1987. Matching that rate of increase was polyester; staple and filament production both grewin 1987. The recovery for polyester followed a $1.1 \%$ decline in 1986 Nylon was up $6.9 \%$ in 1987 as demand for new generation broadloom continued. The only poor showing was from acrylic fiber, production of which continued to flounder. Output dropped $4.1 \%$ in 1987 following a $2.4 \%$ decline in 1986 

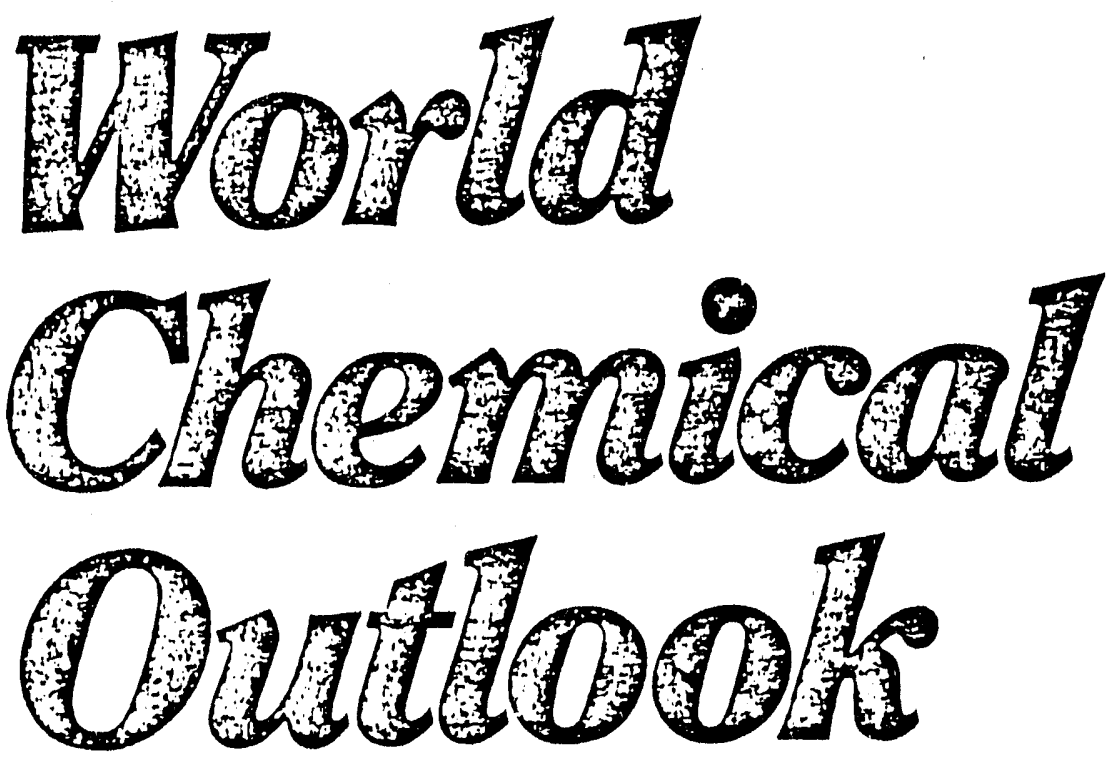

InitedStates

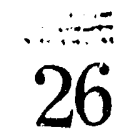

Foreign Trade

29

Western Europe

32

Japan

40

Canada

43

U.S.S.R./Eastern Europe 45

Mexico
What a difference four or five years can make.

Reporting on the outlook for the world's chemical industry at the end of 1982, "widespread malaise" were the words that C\&EN used. "Production of chemicals has been cut back drasticali.y," we reported at that time, and plant capacity is "far in excess of any foreseeable demand. Producers increasingly find themselves strapped financially."

Since then, however, chemical companies throughout the industrialized Western World have in. flicted a massive revamping upon themselves. It has not been without pain. Tens of thousands of jobs have been wiped out. Hundreds of mil. lions of dollars worth of operating assets have been jettisoned. Research and investment programs have been radically reshaped.

Demand for chemicals has in. creased in the past five years. As a result, output of industrial chemicals and synthetic materials in the U.S. this year is more than $40 \%$ high. er than in 1982. And in the major chemical-producing countries of Western Europe and in Japan, chemical output is up 15 to $30 \%$, as well.

That's hardly' exceptional grow'th, by any means. But with production capacity slashed, in many key product areas plants now are being pushed to their design limits and producers are reaping the rewardsin higher prices, higher productivity, and increased profitability - that stem from a seller's market.

In a relatively slow-growing glob. al economy', next year's harvest may be less bountiful. But the world's chemical industry now seems to have its house in good enough or. der that it will be able to withstand an economic slump, should it occur, better than it could in the early' 1980 s. 


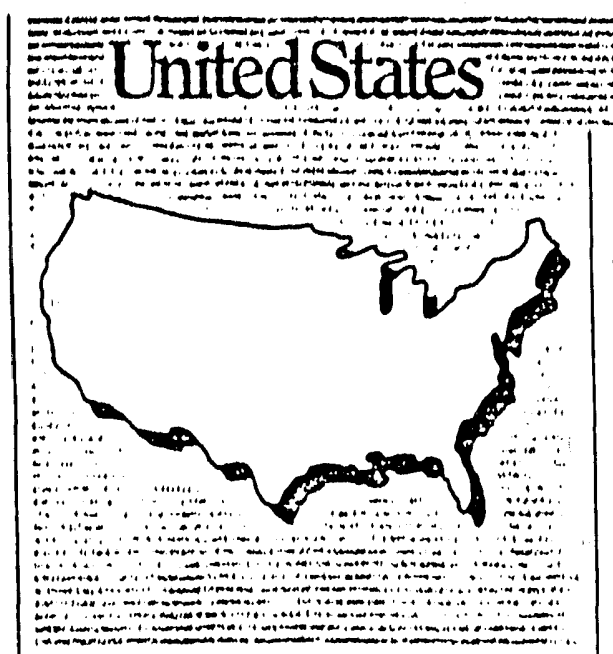

A much slimmed down chemical industry is running many of its plants full out to meet current demand

\section{David M. Klefer, C\&EN Washington}

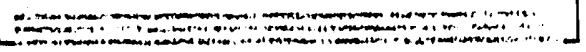

This autumn has witnessed chaotic turmoil in U.S. investment and currency exchange markets. Deep and recalcitrant deficits continue to sorely beset both the federal budget and the U.S. balance of foreign trade. Auto sales are slumping and new housing starts are on a decline. Consumer confidence may be ebbing, and, in the wake of the recent debacle on Wall Street, predictions of impending recession, although still not the consensus among economists, are becoming more common.

So who is crying all the way to the bank? U.S. chemical producers, that's who.

This year, producers of basic industrial chemicals, plastics, and fibers will boost their sales at least $10 \%$ to about $\$ 90$ billion (exclusive of sales of foreign subsidiaries), thanks to increased demand both at home and abroad and to higher selling prices. For the broader chemicals and allied products industry, sales will show a slightly stronger gain of 11 to $12 \%$.

But it is the industry's profitability that really is on a roll. Net income for makers of basic chemicals and synthetic materials will surge $40 \%$ or even a bit more in 1987, to about $\$ 7$ billion. That's a new high by a long shot. Profit margins are

\section{Profits up sharply as producers reap benefits of restructuring}

higher than at any time in the past decade as cutbacks in overhead and improved operating efficiency permit many companies to carry more of each dollar of revenue down to the bottom line. Earnings for the overall chemicals and allied products industry, meanwhile, will increase almost as much to about $\$ 18$ billion.

Several factors are responsible for this year's favorable performance by the chemical industry. Strong consumer demand throughout the year has benefited many chemical end markets, including packaging, apparel, appliances, furniture, and electronics. As a result, output of plastics and fibers and of the chemical intermediates that are needed to make them has risen steadily throughout the year. For the year as a whole, production of industrial chemicals and synthetic materials will be about $9 \%$ higher than in 1986. And for the overall chemicals and allied products industry the increase in output will be about $6 \%$. Both figures are considerably higher than the $3 \%$ increase in production likely this year for U.S. industry as a whole.

Meanwhile, for the second year in a row, the chemical industry is harvesting the fruits of the drastic reorganization that it imposed upon its operations in recent years, especially in 1985. The chronic excess capacity, slow market growth, depressed prices, cutthroat competition, and consequent lackluster earnings that plagued chemical companies throughout the early 1980 s led to widespread programs for repositioning, rationalization, and restructuring. Marginally profitable and money-losing businesses were shut down or sold off. Staffs were cut to the bone. And many major companies shifted their emphasis away from their traditional commodity chemical lines to focus more on the development of specialty products. These, presumably, will be less prone to competition and more likely to garner a favorable return on investment. Monsanto, for one, has slashed its investment in commodity petrochemicals from about a quarter of its total assets in 1980 to only $3 \%$ now.

The combination of increased output and scaled back plant capacity has greatly enhanced the industry's productivity. For the first time in several years, too, producers of many chemical products are enjoying a sellers' market and operating their facilities full out. In this year's third quarter, according to Federal Reserve Board statistics, plant utilization in the chemical industry rose to $84 \%$ of capacity, up from $80 \%$ a year earlier. The industry's operating rate has not been higher since 1974 , and just five years ago it was as low as $68 \%$.

In some notable old-line product areas, moreover, plants now are operating even closer to their upper limit. Chlorine and caustic soda producers, for example, were running their plants at about $90 \%$ of capacity-or over $100 \%$ of "effective" capacity, allowing for plants temporarily shut down-this fall, according to the Chlorine Institute. Output of the two workhorse coproducts will be up 4 to $6 \%$ this year to the highest level since 1980, largely because of strong demand from producers of vinyl chloride and other organic chemicals and from the pulp and paper industry. At the same time, however, with some 20 plants shuttered during the 1980 s, chloralkali producers are making do with about $13 \%$ less capacity than they had in 1982. As a result, supplies are tight and suppliers, for a change, 
now are thinkirig of expanding rath. er than shrinking capacity.

Ethylene producers, too, are hard pressed to keep customers supplied. Output this year will rise only a modest 37 , more because of capacity restraints than slow growth in demand. Current U.S. capacity of about 35 million $l b$ per year is operating at well over $90 \%$, so that further growth will be dependent on debottlenecking present units, upgrading their technology, or restarting plants now mothballed.

Makers of a number of other basic petrochemicals, especially monomers for making plastics, are similarly hard pressed to keep customers satisfied. And in the plastics industry itself, with total production for the first nine months of 1987 up $10 \%$ to 36 billion $\mathrm{lb}$, producers are having little problem in finding a buyer for every pound they can turn out. Even man-made fiber plants are humming close to capacity.

All of which leave chemical companies, for a change, sitting in the catbird seat. Selling prices reflect this. Producer prices for industrial chemicals, after having sagged steeply last year in response to the sharp decline in the cost of petroleumbased feedstocks, have rebounded sharply throughout most of 1987. Although for the year as a whole they will be up, on average, just about $4 \%$, right now they stand 7 to $8 \%$ higher than at the end of 1986. Plastics prices, meanwhile, are more than $15 \%$ higher. Feedstocks also cost more this y'ear, but chemical makers are now in a good position to pass such increases, and more, along to their customers.

The continuing slump in the val. ue of the U.S. dollar relative to major foreign currencies has been yet another fundamental plus for the chemical industry. For one thing. earnings from the industry's farflung operations abroad are magnified when translated into dollars at increasingly favorable exchange rates. Even more importint now, how'ever, U.S. chemicnls are gaining a strong price advantage in overseas markets when competing with products made in Europe or Japan. As a result, $\$ 26$ billion worth of U.S.-made chemicals will be sold to foreign customers this year, 15";

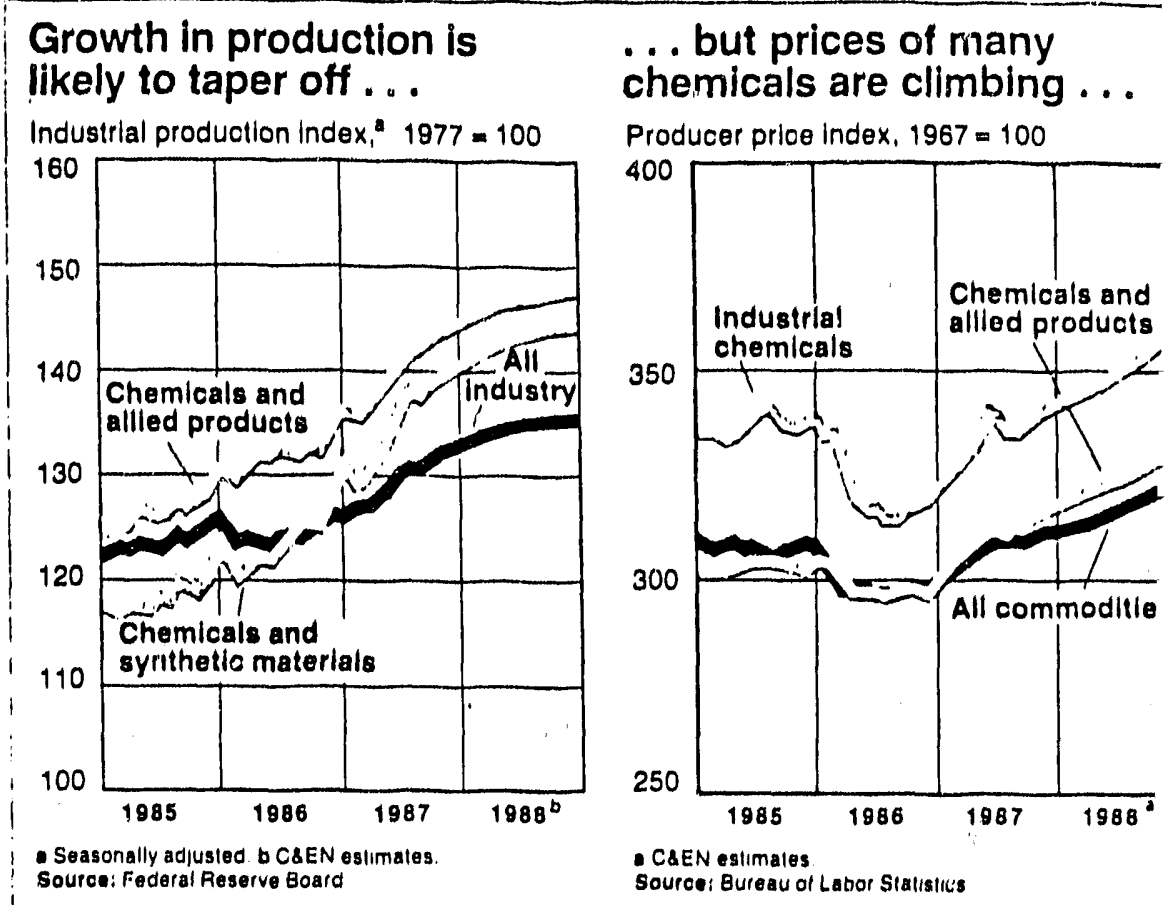

... and a steady rise in sales volume....

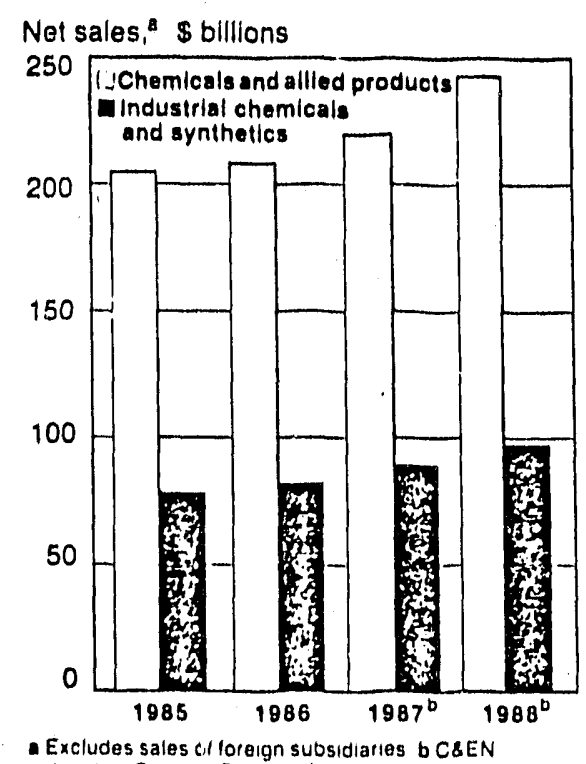
eslimales. Source: Buigau of the Census

more than in 1986 , a hefty $\$ 3.4$ billion increase over 1986 to U.S. companies' sales volume. At the same time, of course, the weak dollar has made U.S. chemical companies look like cheap and tempting targets to foreign companies interested in exparding in the big U.S. market.

All in all, increased exports, higher sales prices, strong demand, and improved efficiency have provided the U.S chemical industry with the leverage, this year and last, to put its finances in better shape than at any time in more than a decat Can the string be extended to thi years?

That depends, of course, on 1 continued health of the overall U economy. Economists and busin: analysts generally hive been mi erately optimistic for 1988. M/ost lookıng for gross mational produ crease about 1.5 to $2.5 \%-$ a rate growth that probably will be sligh below this yeur's. And the const sus is that, although the rate of after adjustment for inflation, fo 
pansion may slow during the latier half of 1988, the U.S. will enjoy an unprecedented sixth year of steady economic progress.

Probably the biggest uncertainty at present is the potential fallout from the stock market collapse. It is still ton early to assess just how the $\$ 1$ trillion or more in losses suffered by investors thic past October and November will impact consumers' spending plans or husinessmen's investment decisions. But consumers have been the linchpin in the economic expansion of the past few years, and if they indeed have been badly shaken by events on Wall Street, further growth in gross national product would likely he slowed-or even stopped.

If the economy does manage to eke ou' another year of slow growth, 1988 will be one more period of high production, rising sales, and st sne profits for U.S. chemical firrils. It is true, certainly, that two of their most important marketshousing and the automobile industry', both of which have been slumping this year-are likely to be less buoyant in 1988 as well. Housing starts this past October were at the lowest level since early 1983, and, for the yea: as a whole, starts probably will be down 10\% from 1986. A decline of nearly the same size would not be surprising for next year, also. That, in turn, will undercut a big market for plastics, coatings, and fibers.

The automotive market, another vast outlet for these chemical products, also is facing cloudy prospects. For all of 1987, its sales probably will t'stal about 10 million cars, down sharply from the 11.5 million sold last year. Consequently, car makers have been trimming back their output since midyear. Auto production is likely to total about 7.1 million units for the entire year, down 9 to $10 \%$ from 1986. And already, the three major U.S. car companies have trimmed their production schedules for 1988's first quarter to a level $13 \%$ below what they rolled off their assembly liries in this vear's first three wionths. For all of 1988, output is likely to drop at least $5 \%$.

Growih is likely to slow, also, for demand from other outlets, such as appliance and furniture makers and the textile industry. But even if chemical production does not rise appreciably above its present level, it will average about $4 \%$ higher next year than in 1987.

It's more likely, though, that production of chemicals, plastics, and synthetic fibers will rise 5 to $6 \%$. Prices, too, probably will be 4 to $5 \%$ higher next year. That works out to at least a $10 \%$ increase in sales, to about $\$ 100$ billion. And with costs under good control and plants operating mostly at optimum rates, profits are expected to continue to move up smartly. Although growth is not likely to be as exterisive as this year's, a further rise of 15 to $20 \%$ seems a good bet.

On the other hand, if the economy should fall into recession before the end of 1988-an event that every business analyst is thinking about at fresent but most are still dismissing-chemical industry executives argue that most companies are now well positioned to ward off its effects better than at any time in the recent past.

The industry's leaner, fitter stature and robust balance sheets have made it more resistant to a slump in demand for its products. Earnings would be hurt, certainly, but they probably would hold up reasonably close to this year's levels.

Continued moderate growth is likely for production of major chemicals and polymers

\begin{tabular}{|c|c|c|c|c|}
\hline & 1985 & 1986 & 1987 & 1988 \\
\hline \multicolumn{5}{|c|}{ INORGANIC CHEMICALS } \\
\hline \multicolumn{5}{|c|}{ Thousands of tons unless otherwise indicated } \\
\hline Ammonia & 17,319 & 14,474 & 15,650 & 16,000 \\
\hline Chlorine gas & 10,402 & 10.436 & 10,900 & 11,200 \\
\hline Hydrochloric & 2.803 & 2.413 & 2,450 & 2,550 \\
\hline Nitric acid & 7,645 & 6.734 & 6.800 & 7.100 \\
\hline Oxygen, billions of cu ft & 357 & 347 & 365 & 380 \\
\hline Phosphori & 10.607 & 9.578 & 10,300 & 10.600 \\
\hline Sodiu & $10, .70$ & 10.691 & 11.400 & 11.700 \\
\hline Șulfuric acid & 39,890 & 35.759 & 38.500 & 40.000 \\
\hline \multicolumn{5}{|c|}{ ORGANIC CHEMICALS } \\
\hline \multicolumn{5}{|c|}{ Millions of lo unless otherwise indicated } \\
\hline Acellc acld & 2,897 & $2.7 \div 3$ & 3.000 & 3.150 \\
\hline Acetone & 1,788 & 1,910 & 2.050 & 2,100 \\
\hline Acrylonilitie & 2.349 & 2.182 & 2.400 & 2,550 \\
\hline Benzene, millions of gala & $1: 283$ & 1.362 & 1.520 & 1,600 \\
\hline Buladiene & 2.340 & 2.546 & 2.700 & 2,800 \\
\hline Cumene & 2.627 & 3.745 & 200 & 4.500 \\
\hline Cyclohexa & 1.657 & 2.070 & $<.250$ & 2.400 \\
\hline Eihylene & 29.847 & 32,859 & 33.800 & 35.500 \\
\hline Elhylene glyco & $4, i 78$ & 4,771 & 4,400 & 4,700 \\
\hline
\end{tabular}

\begin{tabular}{|c|c|c|c|c|}
\hline & 1985 & 1986 & 1087 & 1988 \\
\hline Formaldehyte & 5,606 & 5.549 & 5,800 & 6,000 \\
\hline Methanol & 5.003 & 7.205 & 7.450 & 7,800 \\
\hline Phenol & 2,841 & 3,115 & 3,300 & 3,450 \\
\hline Phthalic anhydrlde & 820 & 863 & 1.050 & 1,100 \\
\hline Propylene & 14,887 & 16.522 & 18.200 & $i 9,600$ \\
\hline Styrene & 7,622 & 7.888 & 8.200 & 8,600 \\
\hline$a x$ lene & 675 & 788 & 950 & 1.000 \\
\hline p-Xylene & 4.779 & 5.035 & 5,300 & 5,600 \\
\hline \multicolumn{5}{|l|}{ PLASTICS. } \\
\hline \multicolumn{5}{|l|}{ Millions of ib } \\
\hline Polyethylene, high density & 6.671 & $7,18=$ & 8.000 & 8.500 \\
\hline Polyethylene, low density & 8.889 & 8,9013 & 9.700 & 10,200 \\
\hline Polypropylene & 5,139 & $5,8 \div 2$ & 6.650 & 7,100 \\
\hline Polystyrene & 4.054 & 4,470 & 4,800 & 5,000 \\
\hline Polyvinyl chlorlde & 6.772 & 7,256 & 7.950 & 8.250 \\
\hline \multicolumn{5}{|l|}{ SYNTHETIC FIBERS_ } \\
\hline \multicolumn{5}{|l|}{ Millions of ib } \\
\hline Acrylic and medacryllc & 631 & 616 & 630 & 650 \\
\hline Nyion & 2.343 & $2.5: 4$ & 2.750 & 2.850 \\
\hline Olellin and vinyon & 1,249 & 1,393 & 1,480 & 1.550 \\
\hline Polyester & 3.341 & 3.305 & 3.550 & 3,650 \\
\hline
\end{tabular}




\section{ForeignTrade}

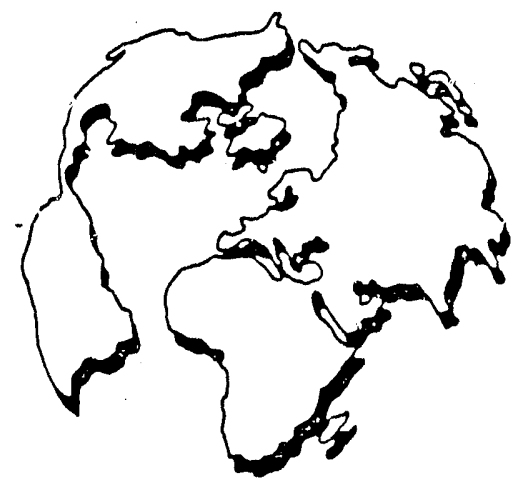

Thanks to the sagging dollar, U.S. chemicals

are making bigger

inroads in European

and Asian markets

Earl V. Anderson, C\&EN New York

The U.S. chemical industry is continuing to rebuild its once-dwindling chemical trade surplus, which had gradually shrunk from an im. pressive $\$ 12.1$ billion surplus in 1980 to $\$ 7.2$ billion by 1985 . The indus. try pushed its surplus slightly higher to $\$ 7.8$ billion last year, on the strength of a $5 \%$ increase in chemical exports.

This year, however, foreign trade of the U.S. chemical industry will increase substantially more. Thanks to a dollar that continues to grow weaker against major foreign currencies, chemical exports will i.mp a healthy $15 \%$ to about $\$ 26.2$ iil. lion. Meanwhile, the weaker dullar will help to limit chemical import grow'th to only $5 \%$. If chemical imports do, in fact, weigh in at $\$ 15.7$ billion this year, as expected, the U.S. chemical trade surplus will expand $\mathrm{to} \$ 10.5$ billion. And the chemical industry will have recouped two thirds of the decline in its trade surplus that it suffered in the early' $1980 \mathrm{~s}$.

Given this year's strong export perlormance, the U $\zeta$. share of worici chemical exports might be expected to increase. It won't. It will slip slightly to Itt'i from last year's $145^{\prime} ;$ and the even higher 15 to $17 \%$ range in which it hovered dur.

\section{U.S. surplus in chemical trade broadens markedly as exports of chemical products surge}

ing the early 1980s, when U.S. chemical export performance was much less vigorous than it is this year.

Why this statistical aberration? It certainly isn't because other countries are outperforming the U.S. when it comes to exporting chemicals. The answer, again, lies with the depreciating dollar.

Measured in dollars, world chemical exports this year will fall just short of $\$ 200$ billion. That's about a $15 \%$ advance, roughly the same percentage that world chemical exports (measured again in dollars) grew last year.

But realistically, the economies of the w'orld's major industrialized na" tions just aren't strong enough to support that kind of growth in chemical exports. And the debt problems of many of the developing countries, particularly some of those in Latin America, make it impossible for them to boost their imports by such a large amount.
A more reasonable "guesstimate" of world chemical export growth this year is about $5 \%$ in real terms. The inflated 15\% dollar-based figure results from the swiftly changing exchange rates of the dollar against other currencies.

Take, for example, the chemical exports of the European Communi. ty (EC). Most recent complete EC statistics (through June) show that EC chemical exports are actually running about $1 \%$ lower than they were last year. But EC reports its export figures in European currency units, or ECUs, which are weighted "bas. ket" units based on the gross na. tional product and trade of member countries.

In 1986, one U.S. dollar equaled 1.063 ECUs. This year, however, a dollar equals only $0.880 \mathrm{ECU}, 17$ (i) lower than last year's conversion rate. Not surprisingly, EC chemical exports, measured in dollars, are up $19.5 \%$ over last year, even though they are dow $n 1.2 \%$ in ECUs.

\section{Cheaper dollar inflates value of world chemical trade...}

Total world chemical exports. $\$$ billions

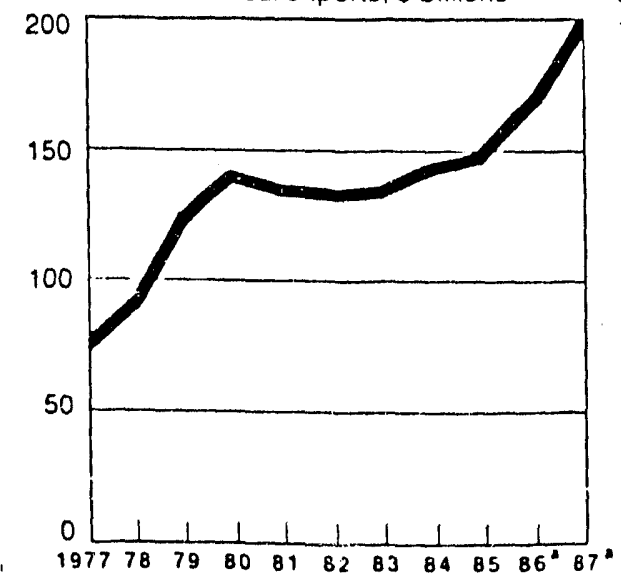

... but deflates U.S. share of the total value

U.S. chemical exports, $\%$ of world lotal ${ }^{b}$

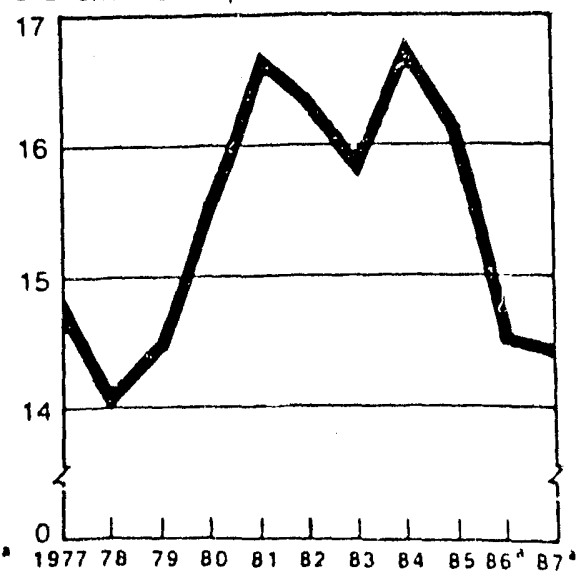

- CBEN eslimates b Delined as U S chemical exporis as percent ol worla chemical exnoris less U $S$ chemic al imporis Sources Unilea Nations Organization lor Economic Coopetalion \& Development. European Comimunity Japan Ministiy ol Intemalional Trade \& inaustiy 


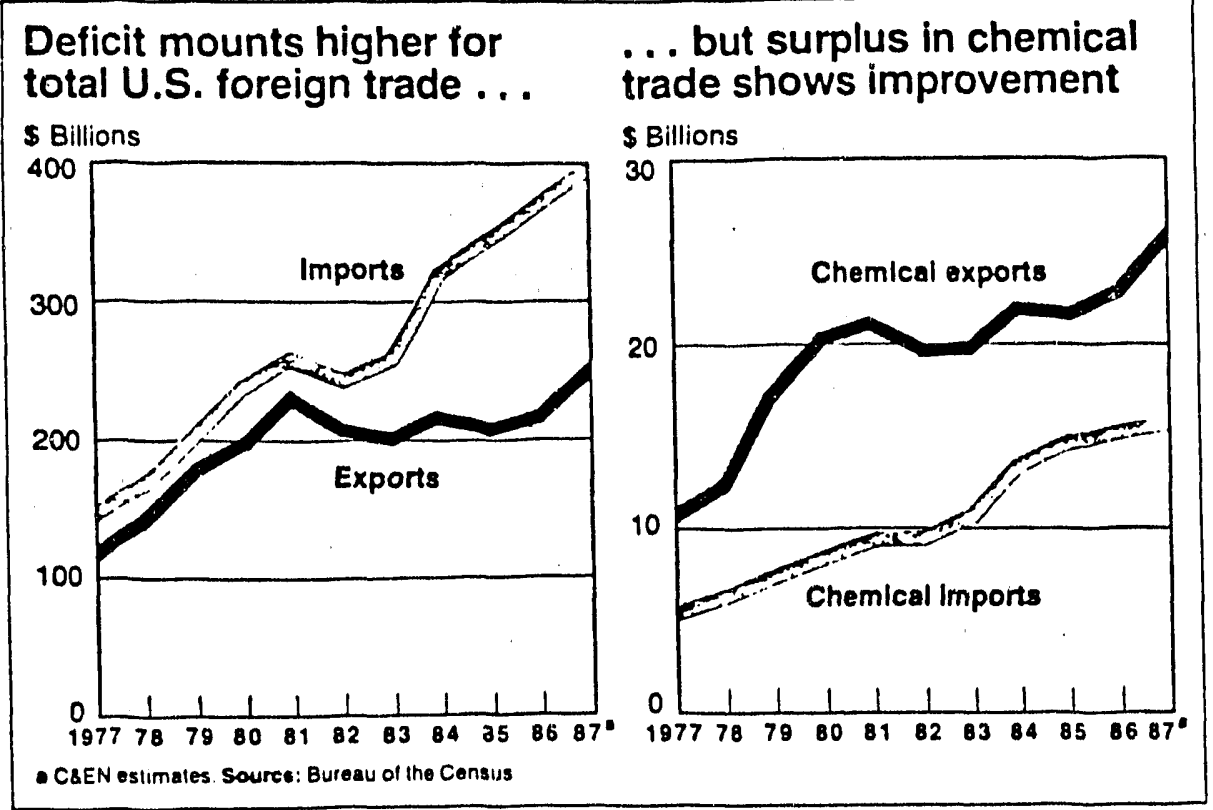

This is why U.S. chemical companies seem to be denied a higher share of world chemical exports, despite their strong export effort this year. The same story is repeated in Japan, where 1987 chemical exports will be $20 \%$ higher in terms of dollars, but less than $5 \%$ higher when valued in yen.

Because the weaker dollar makes imports from the U.S. less expensive in those countries whose currencies have appreciated most against the dollar, it is not surprising that most of the gains in U.S. chemical exports have come in the major industrialized nations. U.S. chemical exports to Western Europe, for in- stance, will be about $18 \%$ higher than they were last year. And the countries of Western Europe, as a bloc, make up the largest single U.S. chemical export market.

Although the Canadian dollar has not appreciated as much against the U.S. dollar as some European currencies have (especially the West German deutsche mark), U.S. chemical exports to Canada will score an impressive $30 \%$ advance this year. Chalk that up primarily to Canada's strong economy. U.S. chemical exports to Japan, however, are only $10 \%$ higher than last year, even though the yen has appreciated dramatically against the U.S. dollar.

\section{U.S. is stepping up its} petroleum imports ... Billions of barrels

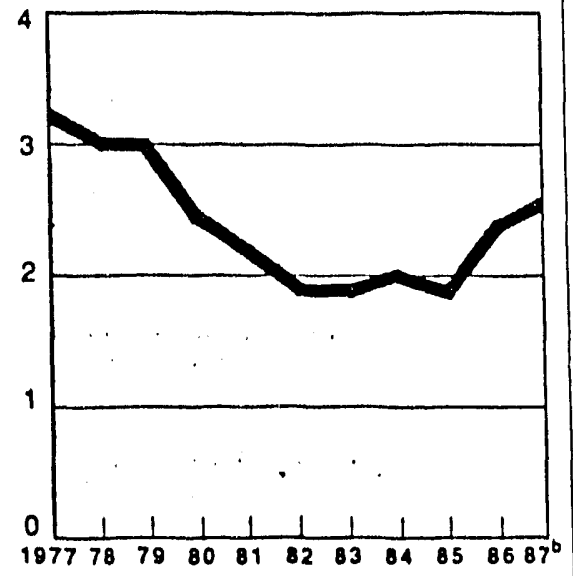

... as higher prices escalate their total cost

$\$$ Billions"

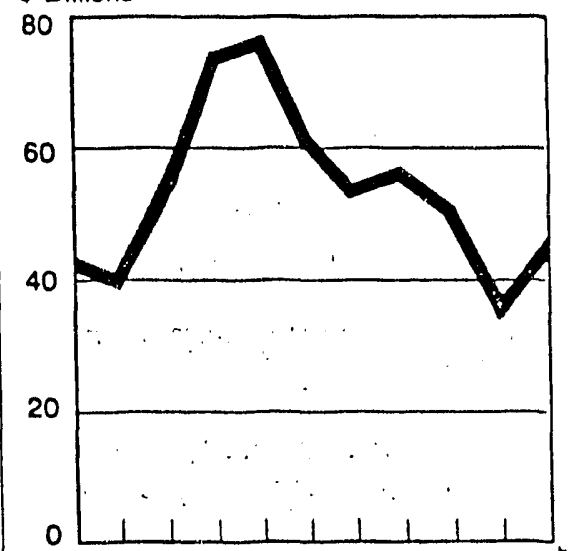

$197778 \quad 798081828384858687^{\circ}$

- All pelroleuin producis b CAEN estimales Source: Bureau of the Census

Surge in U.S. chemical exports is sparked by organic chemicals and plastics

\begin{tabular}{|c|c|c|c|c|c|c|c|c|}
\hline \multirow[b]{2}{*}{ S Millions } & \multicolumn{4}{|c|}{ U.S. chemical exporte } & \multicolumn{4}{|c|}{ U.S. chemical imports } \\
\hline & $1987^{\circ}$ & 1986 & 1985 & 1884 & $1987^{\circ}$ & 1086 & 1985 & 1984 \\
\hline Orgonlc chemicals & $\$ 7,650$ & $\$ 6.293$ & $\$ 6,012$ & $\$ 6,093$ & $\$ 5,385$ & $\$ 4,704$ & $S 4,576$ & $\$ 4,265$ \\
\hline Plastics and resins & 5,400 & 4,301 & 3.777 & 4,050 & 1,930 & 1,837 & 1,631 & 1,484 \\
\hline Medicinals and pharmaceutlcals & 3.275 & 3.090 & 2,708 & 2,628 & 1,380 & 1,240 & 1,084 & 931 \\
\hline Fertilizers, manufactured & 2,095 & 1,935 & 2,160 & 1,815 & 770 & 865 & 967 & 1,142 \\
\hline Inorganic chemicals & 2,045 & 1.771 & 1.967 & 2,184 & 1,995 & 1,894 & 1,984 & 2.064 \\
\hline Radioactive malerials & 915 & 1,302 & 1.311 & 1,421 & 800 & 1.382 & 1,417 & 1.394 \\
\hline Pestlcides and disinfectants & 785 & 664 & 614 & 707 & 410 & 580 & 399 & 308 \\
\hline Flavors, pertumes, cosmellcs, and tolletries & 575 & 488 & 478 & 498 & 740 & 679 & 577 & 521 \\
\hline Pigments, paints, and varnishes & 420 & 333 & 322 & 335 & 425 & 348 & 266 & 232 \\
\hline Cleaning and polishing materlals & 365 & 302 & 292 & 308 & 205 & 214 & 172 & 118 \\
\hline Dyeing, tanning, and coloring & 210 & 174 & 139 & 158 & 580 & 487 & 352 & 358 \\
\hline Explosives and pyrotechnics & 80 & 81 & 100 & 146 & 125 & 111 & 103 & 84 \\
\hline Miscellaneous & 2.385 & 2.032 & 1.878 & 1,992 & 955 & 660 & 1,005 & 797 \\
\hline TOTAL & $\$ 26,200$ & $\$ 22,766$ & $\$ 21,759$ & $\$ 22,336$ & $\$ 15,700$ & $\$ 15,001$ & $\$ 14,533$ & $\$ 13,697$ \\
\hline
\end{tabular}

- CSEN estimates Source: Bureau of the Census 
U.S. trade deficit rises despite higher exports of chemicals and other manufactured goods

\begin{tabular}{|c|c|c|c|c|c|c|c|c|}
\hline \multirow{2}{*}{8 sillions } & \multicolumn{4}{|c|}{ U.S. export: } & \multicolumn{4}{|c|}{ U.S. Import: } \\
\hline & $1087^{\circ}$ & 1986 & 1985 & 1084 & $1987^{\circ}$ & 1986 & 1985 & 1804 \\
\hline Chemlcals & $\$ 26.2$ & 522.8 & $\$ 21.8$ & $\$ 22.3$ & $\$ 15.7$ & $\$ 15.0$ & $\$ 14.5$ & $\$ 13.7$ \\
\hline Machinery and transportalion equipment & 104.7 & 95.3 & 94.3 & 90.0 & 173.7 & 161.6 & 137.3 & 119.2 \\
\hline Other manulactured goods & 35.7 & 30.6 & 29.3 & 30.8 & 118.6 & 105.5 & 95.0 & 88.6 \\
\hline Food and live animals & 18.7 & 17.3 & 19.3 & 24.5 & 20.8 & 20.8 & 18.6 & 18.0 \\
\hline Beverages and lobacco & 3.4 & 2.9 & 3.0 & 2.9 & 4.0 & 3.9 & 3.7 & 3.7 \\
\hline Animal and regetable olls and fats & 1.0 & 1.0 & 1.4 & 1.9 & 0.4 & 0.5 & 0.7 & 0.7 \\
\hline Mineral fuels, lubricants, and related materials & 7.6 & 8.1 & 10.0 & 9.3 & 43.6 & 37.3 & 53.9 & 61.0 \\
\hline Crude materials (inedible) other than fuels & 19.5 & 17.3 & 16.9 & 20.2 & 11.2 & 10.4 & 10.4 & 11.1 \\
\hline All other products & 19.9 & 11.0 & 11.0 & 10.1 & 12.0 & 14.9 & 11.1 & 9.8 \\
\hline TOTAL & $\$ 245.0^{b}$ & $\$ 217.3^{\circ}$ & $\$ 213.1^{b}$ & $\$ 217.9^{b}$ & $\$ 400.0$ & $\$ 370.0$ & $\$ 345.3$ & $\$ 325.7$ \\
\hline
\end{tabular}

- CAEN estimates. I Includes re-exported imports (nol included in individual product categorles). Source: Bureau of the Census

Where U.S. chemical exports, along with the exports of most other products, continue to suffer is in the debt-ridden developing nations. The most indebted nations, such as Brazil, are in Latin America, which is a very large and important outlet for U.S. chemicals.

In 1980, Latin America accounted for almost $24 \%$ of all U.S. chemical exports. But the debt problems of several of the region's largest and most economically advanced nations have put the brake on their ability to import. This year, for instance, U.S. chemical exports to Latin America will increase a miserly $1 \%$ over 1986. And the share of U.S. chemical exports that Latin America takes in will drop to only $15 \%$.

On the other hand, U.S. chemical exports to developing nations in Asia are increasing rapidly. These nations, in fact, now rival Latin America as a big market for U.S. chernical exports.

The developing countries of Asia don't have the debt burden that Latin American countries do. And, led by the so-called newly industrialized countries, such as Taiwan, South Korea, Hong Kong, and Singapore, industrial development in this area has been swift

As a result, this year U.S chemical exports to the area likely will be up almost 20\%. And its importance as a chemical market, compared with Latin America, has grown markedly. This year, the developing countries of Asia will import $15 \%$ of all U.S. chemical exports, about the same as Latin America's share. In 1980, those shares were $13 \%$ and $24 \%$, respectively.
The betting is that developing Asia will continue to grow as a market for U.S. chemicals. But whether Latin America can regain its former stature is a big question. Most observers don't think it will happen any time soon.

It's a catch-22 situation in Latin America. The most heavily indebted countries there can't increase their borrowing to pay for additional imports. And to pay for their existing debt, they must run large trade surpluses. This, in turn, means throttling back on imports and increasing their own exports.

For them to increase their exports, however, implies that the industrialized countries, especially the U.S., must increase their imports from the developing country' debtors. But the U.S., of course, has a troublesome trade deficit of its own.

Total U.S. exports this year probably will increase $13 \%$ to $\$ 245$ billion. Imports, although held to only an $8 \%$ advance, nevertheless will reach a record $\$ 400$ billion. This combination will push the U.S. trade deficit up slightly to $\$ 155$ billion from last year's $\$ 152.7$ billion, despite the effects of a much weaker dollar.

The U.S. will pay $\$ 45$ billion for imports of oil and related products, almost $\$ 5$ billion more than last year. Without this increase, the trade deficit would have been slightly lower than if was last year.

One expert sees a danger in low. ering the trade deficit too rapidly. Altert M. Wojnilower, senior adviser and managing director of First Boston Corp., says that the deficit can be lowered by increasing ex- ports and substituting domestic products for imports, by reducing domestic demand, or by protectionism. The first proposal, he say's, could lead to inflation. The second is a euphemism for recession. And the third, protectionism, is hardly iesirable. "I see no choice," say's Wojnilower, "but to be content with glacial progress until the [newly industrialized countries] become vigorous buyers as well as sellers."

\begin{tabular}{|c|c|c|}
\hline s Millions & $1987^{\circ}$ & 1 \\
\hline \multicolumn{3}{|c|}{ U.S. CHEMICAL EXPORTS } \\
\hline Canada & $\$ 3,460$ & $\$ 2$ \\
\hline Latin America & 4,060 & \\
\hline Western Europe & 8,330 & \\
\hline Eastern Europe & 365 & \\
\hline Japan & 3,380 & \\
\hline Australasla & 840 & \\
\hline Communist Asia & 605 & \\
\hline Middle Easl & 365 & \\
\hline Rest of Asla & 4,035 & 3 \\
\hline Alrlca & 500 & \\
\hline Other & 260 & \\
\hline TOTAL & $\$ 26,200$ & $\$ 22$ \\
\hline
\end{tabular}

\begin{tabular}{lrr} 
U.S. CHEMICAL IMPORTS & & \\
\cline { 2 - 3 } Canada & $\$ 2,985$ & $\$ 2$ \\
Lalln America & 960 & \\
Western Europe & 7,865 & 7 \\
Eastern Europe & 155 & \\
Japan & 2,070 & 1 \\
Australasla & 235 & \\
Communisi Asla & 205 & \\
Middle East & 265 & \\
Rest of Asla & 645 & \\
Alrica & 80 & \\
Oiner & 235 & \\
\multicolumn{1}{l}{ TOTAL } & $\$ 15,700$ & $\$ 15$, \\
CSEN estimates Source: Bureau of ine Census & \\
\hline
\end{tabular}




\section{HPI's role in chemicals' future}

Many hydrocarbon processes must have catalyst and chemicals to operate, but some of these processes are also major suppliers of important chemicals

\section{H. L. Hoffman and L. Riddle, HYDROCARBON PROCESSING Staff}

WHAT DO FUELS and chemicals have in common? A foolish question. Fuels ARE chemicals. Indeed, excluding atomic and subatomic particles, all matter has a chemical composition. Therefore, an attempt to assess the role of fuels manufacture on chemical manufacture must. start with definitions that somehow isolate these two manufacturing entities.

Arbitrary definition. One common distinguishing characteristic is chemical purity of products. Chemical manufacturing makes products that are usually composed of single, specific chemical compounds. Fuels manufacturing makes products having an assortment of chemical compoundsnormally grouped within a given boiling range.

There are many exceptions to this sort of characterization. Processed natural gas, a common fuel, is almost pure methane. On the other hand, modern plastics-recognized as chemical products-are combinations of many chemical compounds. Even a purer form of plastics such as polyethylene has varying molecular weights symbolized by $\left(-\mathrm{CH}_{2}-\right.$ $\left.\mathrm{CH}_{2}-\right)_{n}$. Isn't it ironic that many compounds in refined petroleum fuels have this same molecular symbol?

Defining HPI. The hydrocarbon processing industry (HPI) concerns manufacturing of products from natural gas and crude petroleum oils. Also included are those other natural raw materials such as coal, kerogen and shale oil that are sources of fuels called "synfuels" - denoting these products are made from raw materials other than natural gas or crude petroleum oil.

So the HPI is a major producer and consumer of hundreds (more like thousands) of different chemicals. Gathering supporting statistics remains largely a problem of definition and convention. Whether one chemical or another is included in a specific list often depends on the way its manufacturer is classified.

For the fuels portion of the HPI, U.S. refiners, for example, consumed more than 1,500 billion pounds of crude petroleum oil in 1986. After a few processing steps, about $85 \%$ of the prime feed was converted to fuels products. Most of these products were quickly burned for heat or motive power. Thus, statistics for the fuels portion are less complicated than for the chemicals portion.

Of the remaining $15 \%$ of the raw material, about half was used for energy needed by the refining processes. The other half was divided among a host of processes 10 become intermediaies and final chemical products. Depending on the nature of the processing, and the classification of the manufacturer, these chemicals might be part of the USITC's reported 114 billion pounds of "primary products from pe-

\section{TABLE 1-U.S. production of selected petrochomicals, 1987}

\begin{tabular}{|c|c|c|}
\hline \multirow[b]{2}{*}{ Products } & \multicolumn{2}{|c|}{ Bllilons of pounds } \\
\hline & Jan-Sepl.' & Yrly est." \\
\hline Acetic acid & 2.403 & 3.21 \\
\hline Acrylic acid & 0.622 & 0.83 \\
\hline Acrylonitrile & 1.881 & 2.51 \\
\hline Alpha olelins, $\mathrm{C}_{\diamond}+$ & 1.134 & 1.52 \\
\hline Aniline & 0.709 & 0.95 \\
\hline Benzeno, all grades". & 8.361 & 11.18 \\
\hline Butadiene & 2.096 & 2.80 \\
\hline Butanol, n- & 0.696 & 0.93 \\
\hline Chlorobenzene, mono & 0.175 & 0.23 \\
\hline Cumene & 3.106 & 4.15 \\
\hline Cyclohexane & 1.657 & 2.22 \\
\hline Diethylene glycol & 0.343 & 0.46 \\
\hline Ethyl hexanol, 2 . & 0.464 & 0.65 \\
\hline Ethanol, synthetic & 0.391 & 0.52 \\
\hline Ethylbenzene & 7.243 & 9.68 \\
\hline Ethyl chloride & 0.130 & 0.17 \\
\hline Ethyiene & 25.182 & 33.67 \\
\hline Elhylene glycol & 3.213 & 4.30 \\
\hline Ethylene oxide & 4.326 & 5.78 \\
\hline Isopropanol & 1.019 & 1.36 \\
\hline Maleic anhydride & 0.288 & 0.39 \\
\hline Methanol & 5.445 & 7.28 \\
\hline MTBE & 2.549 & 3.41 \\
\hline Phenol, synthelic & 2.427 & 3.24 \\
\hline Phthalic anhydride & 0.782 & 1.05 \\
\hline Polyethers and polyesters & 1.476 & 1.97 \\
\hline Polyethylene and copolymers & 12.845 & 17.17 \\
\hline Polypropylene & 4.879 & 6.52 \\
\hline Propylene & 13.943 & 18.64 \\
\hline Propylene glycol & 0.593 & 0.79 \\
\hline Styrene monomer & 6.015 & 8.04 \\
\hline Tolvene, all uses". & 5.056 & 6.76 \\
\hline Tolvene diisocyanate & 0.525 & 0.70 \\
\hline Vinyl acelate monomer & 1.847 & 2.47 \\
\hline Vinyl chloride monomer & 6.469 & 8.65 \\
\hline Xylene, $o-$ and $p$. & 4.644 & 6.13 \\
\hline
\end{tabular}

troleum and natural gas" and of the 235 billion pounds of "synthetic organic chernicals" for 1986.' ETHYLENE AND ITS DERIVATIVES-Relating
estImated 1987 productlon data

\begin{tabular}{|c|c|c|c|c|c|c|}
\hline Product & Prod. & $\begin{array}{l}\text { (Lo leed } \\
\text { (por ID) }\end{array}$ & $\begin{array}{l}\text { Blllions o } \\
\text { Inter. } \\
\text { mediate }\end{array}$ & $\begin{array}{l}\text { pounds } \\
\text { (LD loed } \\
\text { per lb) }\end{array}$ & $\begin{array}{l}\text { Equiv. } \\
\text { ethylene }\end{array}$ & $(\%)$ \\
\hline $\begin{array}{l}\text { I.DPEJLLDPE } \\
\text { HDPE } \\
\text { Polyethylene }\end{array}$ & $\begin{array}{r}9.35 \\
7.82 \\
17.17\end{array}$ & - & $\overline{-}$ & $\begin{array}{l}0.98 \\
1.05\end{array}$ & $\begin{array}{r}92 \\
82 \\
174\end{array}$ & 52 \\
\hline $\begin{array}{l}\text { Ethylene glycol } \\
\text { Diethylene glycol } \\
\text { Other } \\
\text { Ethylene oxide }\end{array}$ & $\begin{array}{l}4.30 \\
0.46 \\
-\end{array}$ & $\begin{array}{c}0.80 \\
0.94 \\
-\end{array}$ & $\begin{array}{l}344 \\
0.43 \\
191 \\
5.78\end{array}$ & 089 & 5.1 & 15 \\
\hline $\begin{array}{l}\text { PVC } \\
\text { Oiher } \\
\text { Vinyl chloride }\end{array}$ & $\begin{array}{c}7.47 \\
-\end{array}$ & 1.00 & $\begin{array}{l}7.47 \\
1.18 \\
0.65\end{array}$ & 049 & 42 & 12 \\
\hline $\begin{array}{l}\text { Styrene } \\
\text { Other } \\
\text { Elhylbenzene }\end{array}$ & $\begin{array}{c}0.04 \\
-\end{array}$ & $\begin{array}{c}1.13 \\
-\end{array}$ & $\begin{array}{l}0.09 \\
0.59 \\
0.68\end{array}$ & 027 & 2.6 & 8 \\
\hline $\begin{array}{l}\text { Olelins, alpha } \\
\text { Vinyl acetate } \\
\text { Eithanol } \\
\text { Einyl chlorides } \\
\text { Other }\end{array}$ & $\begin{array}{l}1.52 \\
2.47 \\
0.52 \\
0.17\end{array}$ & $\begin{array}{l}- \\
- \\
-\end{array}$ & $\begin{array}{l}- \\
-\end{array}$ & $\begin{array}{l}130 \\
0.37 \\
0.63 \\
0.49\end{array}$ & $\begin{array}{ll}2 & 0 \\
0 & 9 \\
0 & 3 \\
0 & 1 \\
1 & 1\end{array}$ & $\begin{array}{r}6 \\
3 \\
1 \\
- \\
3\end{array}$ \\
\hline & & & \multicolumn{2}{|c|}{ Ethyleno } & 33.7 & $\overline{100}$ \\
\hline
\end{tabular}

Nole Bold numbers are from Table 1. Orhet numbers are calculated or inlerred Exrluidas invantory shangas NPAA report includes inventory changes and othet dala sources. 


\section{CATALYST PRODUCTION and USE}

TABLE 1- 1987 estimated refining catalysts associated with fuels processing

\begin{tabular}{|c|c|c|c|c|c|c|c|c|}
\hline \multirow{3}{*}{$\begin{array}{l}\text { Refining } \\
\text { processes }\end{array}$} & \multirow{3}{*}{$\begin{array}{c}\text { Capacity, } \\
\text { millions } \\
44 \text { bpos }\end{array}$} & \multicolumn{3}{|c|}{ Typical U.S. averages } & \multirow{2}{*}{\multicolumn{4}{|c|}{$\begin{array}{c}1987 \text { Estimated catalyst market, } \\
\text { millions of U.S. dollars }\end{array}$}} \\
\hline & & \multirow{2}{*}{$\begin{array}{c}\text { Catalyst } \\
\text { consump., } \\
\text { ib/bbi }\end{array}$} & \multirow{2}{*}{$\begin{array}{c}\text { Usage, } \\
\text { millions } \\
\text { of Ib }\end{array}$} & \multirow{2}{*}{$\begin{array}{l}\text { Unit } \\
\text { price, } \\
\text { s/lb }\end{array}$} & & & & \\
\hline & & & & & U.S. & W. Europe & Others & Worl \\
\hline $\begin{array}{l}\text { Cat. cracking } \\
\text { Hydrotreating } \\
\text { Alkylation, } \mathrm{H}_{2} \mathrm{SO} \text {. } \\
\text { Hydrocracking } \\
\text { Cat. reforming } \\
\text { Alkylation, } \mathrm{HF} \\
\text { Isomerization }\end{array}$ & $\begin{array}{l}40 \\
04 \\
0.50 \\
1.0 \\
3.5 \\
0.40 \\
0.25\end{array}$ & $\begin{array}{l}0.2 \\
0.009 \\
18 \\
0.013 \\
0.0033 \\
0.15 \\
0.015\end{array}$ & $\begin{array}{c}380 \\
28 \\
3,300 \\
4.7 \\
4.5 \\
22 \\
1.4\end{array}$ & $\begin{array}{r}0.70 \\
3.00 \\
0.03 \\
10.00 \\
6.50 \\
0.70 \\
6.00\end{array}$ & $\begin{array}{r}250 \\
84 \\
99 \\
47 \\
27 \\
15 \\
8\end{array}$ & $\begin{array}{r}76 \\
42 \\
1 \\
9 \\
15 \\
3 \\
4\end{array}$ & $\begin{array}{r}131 \\
63 \\
6 \\
42 \\
21 \\
5 \\
2\end{array}$ & $\begin{array}{r}457 \\
189 \\
106 \\
98 \\
63 \\
23 \\
14\end{array}$ \\
\hline Oligomerization & 0.05 & - & - & - & - & - & - & $=$ \\
\hline Total & 7 & & & & 530 & 150 & 270 & $\overline{950}$ \\
\hline
\end{tabular}

TABLE 2-Estimated capacities used to ratio catalyst market

\begin{tabular}{|c|c|c|c|c|}
\hline \multirow{2}{*}{$\begin{array}{l}\text { Refining } \\
\text { processes } \\
\end{array}$} & \multicolumn{4}{|c|}{ Millions of bpcd } \\
\hline & U.S. & W. Europe & Others & World" \\
\hline Hydrotreating & 8.4 & 4.3 & 6.3 & 19.0 \\
\hline Cat. cracking & 4.9 & 1.5 & 2.6 & 9.0 \\
\hline Cat. reforming & 3.5 & 2.0 & 2.7 & 8.2 \\
\hline Hydiocracking & 1.0 & 0.2 & 0.9 & 2.1 \\
\hline Alkylation, HF & 0.40 & 0.09 & 0.13 & 0.62 \\
\hline Alkylation, $\mathrm{H}_{2} \mathrm{SO}_{4}$ & 0.50 & 0.007 & 0.03 & 0.54 \\
\hline Isomerization & 0.25 & 0.11 & 0.06 & 0.42 \\
\hline Oligomerization & 0.05 & - & - & - \\
\hline
\end{tabular}

TABLE 3-1987 estimated petrochemical catalysts

\begin{tabular}{lrcr}
\hline \multirow{2}{*}{$\begin{array}{l}\text { Petrochemical } \\
\text { processes }\end{array}$} & \multicolumn{3}{c}{ Millions of U.S. dollars } \\
\cline { 2 - 4 } & U.S. & Others & World \\
\hline Polymerization & 256 & 458 & 714 \\
Organic synthesis & 91 & 164 & 255 \\
Oxidation & 84 & 151 & 235 \\
Syngas & 58 & 105 & 163 \\
Hydrogenation & 37 & 67 & 104 \\
Dehydrogenation & 9 & 15 & 24 \\
\hline Total & 535 & 960 & 1.495
\end{tabular}

TABLE 3-Major catalysts for refining, 1988 estimate

\begin{tabular}{lrrrr}
\hline & \multicolumn{4}{c}{ Millions of dollars } \\
Catalyst type & U.S. & W. Europe & Other & World \\
Catalytic cracking & $\$ 250$ & $\$ 75$ & $\$ 130$ & $\$ 455$ \\
Hydrotreating & 85 & 40 & 65 & 190 \\
Alkylation, H2SO, & 100 & & 5 & 105 \\
Hydrocracking & 45 & 10 & 40 & 95 \\
Catalytic reforming & 25 & 15 & 20 & 60 \\
Alkylation, HF & 15 & 5 & 5 & 25 \\
Isomerization & 10 & 5 & & $\$ 5$ \\
$\quad$ Total & $\$ 530$ & $\$ 150$ & $\$ 265$ & $\$ 945$ \\
\hline
\end{tabular}

TABLE 4-Catalysts for petrochemicals, 1988 estimate

\begin{tabular}{lrrr}
\hline & & Millions of dollars \\
Process & U.S. & $0.4 . \mathbf{S .}$ & Worldwide \\
Polymerization & $\mathbf{\$ 2 6 5}$ & $\$ 480$ & $\$ 75$ \\
Organic synthesis & 95 & 170 & 265 \\
Oxidation & 85 & 155 & 240 \\
Syngas & 60 & 110 & 170 \\
Hydrogenation & 40 & 70 & 110 \\
Dehydrogenation & 10 & 15 & 25 \\
Total & $\mathbf{5 5 5}$ & $\mathbf{\$ 1 , 0 0 0}$ & $\mathbf{\$ 1 , 5 5 5}$ \\
Source: JACA Coip., 1986, adjusled. & & &
\end{tabular}

[1] H.L.Hoffman, "Catalya Usage Tied to Processes". Hydrocarbon Processiag, p41, Feb 1987.

[2] H.L.Hoffmen and L. Riddle, "ITPI's Role in Chemical's Future", Hydrocartion Processing. P41, Feb 1988. 

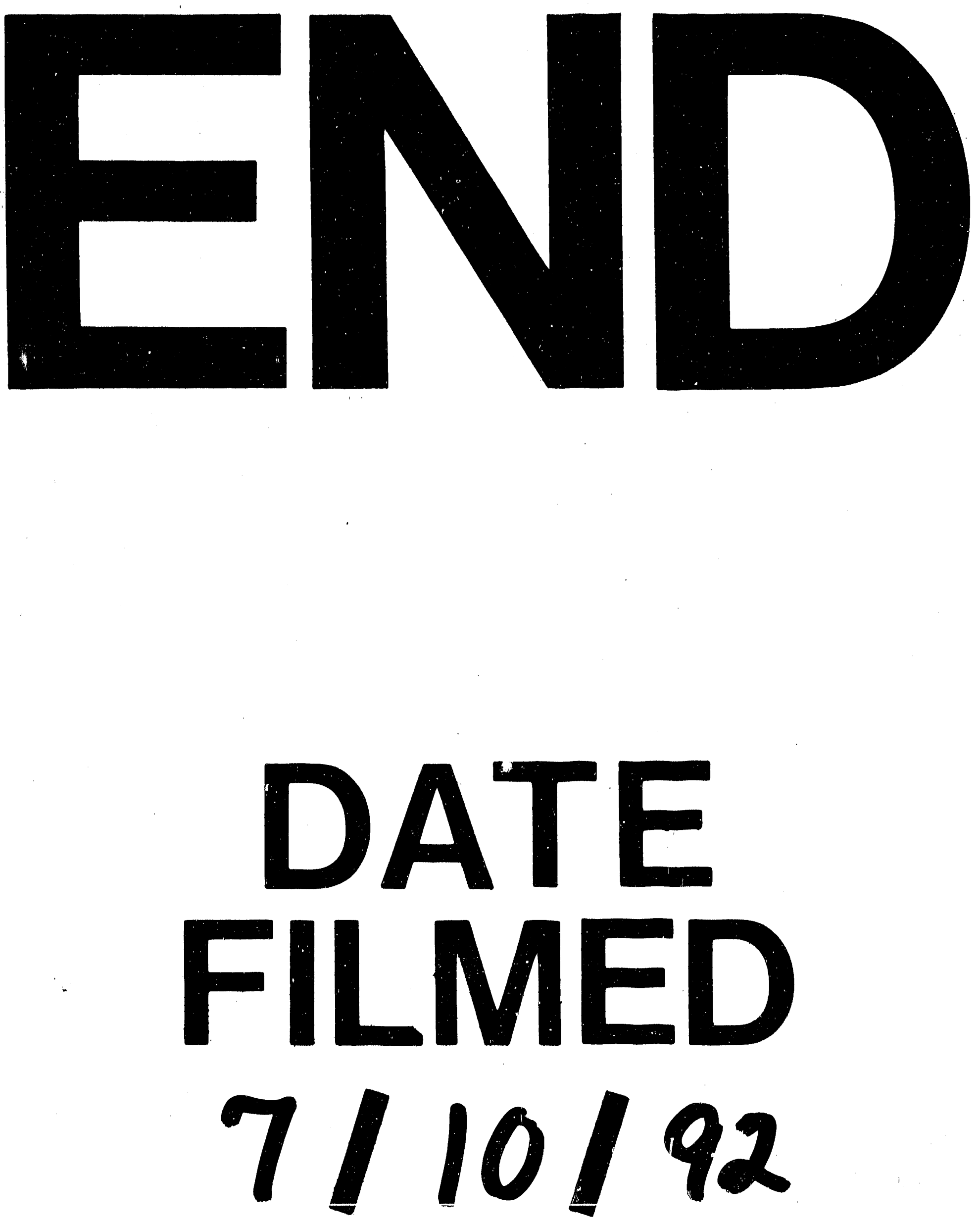

1 
